\title{
Drawing on the Past, Regenerating the Present: A Comparison of the Works of Ayi Kwei Armah and Nicolás Guillén
}

By

NOVIETO, SETOR DONNÉ

\begin{abstract}
A thesis
submitted to the Victoria University of Wellington in fulfilment of the requirements for the degree of

Doctor of Philosophy
\end{abstract}

Victoria University of Wellington 
Yet out of the decay and dung there is always a new flowering. Perhaps it helps to know that. Perhaps it clears the suffering brain.

-Ayi Kwei Armah

La inyección africana en esta tierra es tan profunda, y se cruzan y entrecruzan en nuestra bien regada hidrografía social tantas corrientes capilares, que sería trabajo de miniaturista desenredar el jeroglifico.

-Nicolás Guillén. 
This thesis was conducted under the supervision of

Dr Nicola Gilmour and

Emeritus Professor Mark Williams 


\begin{abstract}
Novelist Ayi Kwei Armah and poet Nicolás Guillén are, respectively, Ghanaian and Cuban writers who embody the efforts of mid-twentieth-century artists to depict the day-to-day socio-political conditions and struggles of societies seeking to move beyond histories of racial and economic oppression. Both engage powerfully and controversially with ongoing debates around damaging colonial histories and disappointing contemporary realities. The achievement of independence did not usher in the new, improved nations sought by way of struggle and suffering in either country. Uncompromisingly, Armah's and Guillén's works portray both the irredeemable parts of colonial histories and those that can be put to the benefit of the present, together with the tension that this disparity between expectation and achievement engenders.
\end{abstract}

Granted the varied nature of the subject matter of the works of the two authors and the seeming lack of relation between them, this study makes use of a selection of theoretical frameworks to find common ground for analysing their work. The analysis of Nicolás Guillén's poetry is based on concepts fundamental to Latin American social and cultural criticism, notably, the ideology of whitening or blanqueamiento, cultural mixing or mestizaje, and feminist criticism. The study of Ayi Kwei Armah's first novel The Beautyful Ones Are Not Yet Born (1968) employs socio-cultural theories including traditional Ghanaian concepts such sankofa and the Akan symbol of adinkra, together with Jean Paul Sartre's concept of the “engaged writer."

This thesis argues that, in spite of their different national and ethnic backgrounds, both writers draw on traditional aspects of African culture to provide the impetus for social and cultural regeneration in their societies. Critics have read Armah as presenting disillusioned and decadent images of Ghana and promoting limited roles for women in his work. Guillén too has been portrayed by critics as offering an objectified representation of 
women in his poetry of the 1920s and 1930s and has been accused of ignoring, as a poet of meztizaje or ethnic mixture, the issues of Blacks and Blackness. This thesis contests these limiting critical positions, arguing that the writers' representations of women, Blacks and Blackness are more positive and progressive than has been allowed. Acknowledging the burden of racist histories, the false promise of postcolonial liberation, the blatant corruption and the unrealised expectations of their times, they nevertheless allow for the possibility of regeneration in the societies they both dissect and, in part, restore. 


\section{Acknowledgements}

I am deeply indebted to God Almighty for being my present help in ages past and my hope for years to come. Most importantly, I express my deepest appreciation first of all, to my family. My success would not have been possible without their deep love, unwavering support and constant prayers. To my Dad, Daniel, "you did not wait for me to finish before you left this Earth.”

I am particularly grateful to my supervisor Dr Nicola Gilmour for accepting the task when I urgently needed a new supervisor. Her patience, her encouragement, her effective supervision style and her fruitful and relevant feedbacks were key in the progress, continuation and completion of this thesis. Nicola, you have been un manatial de poder, ayuda y apoyo. Akpe na wo (Thank you). I also received thought-provoking, insightful and critical comments from Emeritus Professor Mark Williams, my secondary supervisor. His insights into World Literature, especially that of the Caribbean, provided me with the tools to fine-tune the link between Armah and Guillén and for that matter, Cuba and Ghana respectively.

I am particularly indebted to a great literary scholar, Dr James Meffan of the English Programme of Victoria University of Wellington for the three-months of mind-opening and capacity building experience with you. You opened your world of Narratology and Literary Theory to me and you equipped me with skills and tools for life. Thank you James.

My gratitude goes to all the faculty and staff of the School of Languages and Cultures here at the Victoria University of Wellington, most especially Prof. Marco Sonzogni and Dr Catherine Churchman. Dr Richard Millington deserves a special mention as he took me as a friend and at the same time mentored me. Richard, your formal and informal visits and the 
encouragements are GOLDEN and will forever remain in my heart. I appreciate the guidance and invaluable suggestions from Dr Miguel Arnedo-Gómez and Professor Sarah Leggott. Nina, former School Administrator, Ida and the rest of the Administration team deserve a mention.

I also acknowledge Dr Lizzie Towl and Erica Schouten for the valuable and unquantifiable roles that they played in ensuring that this $\mathrm{PhD}$ was put back on track and is completed. Thank you Lizzie and Erica, You are a GIFT to me and to all students of Victoria University. My thanks also go to the staff at the Student Finance office, especially Adrianne Otto, Paige Jarmin, Morgan Wisheart, Dan Napolitano, Nadia Henare, Sammy Young, Stephanie Hunter and William Vandenberg Gracie for the financial advice and help anytime I appear there, and to Barry Lewis and Alana Hamill of the Faculty of Graduate Research, you were an inspiration. Dr Deborah Laurs, Dr Xiaodan Gao, Kirsten Reid and Marie Paterson, all of Te Taiako (Student Learning) were central in this journey. I have no better way of expressing my gratitude than to say kia ora.

Dr Sara Cotterall, that smile and your words of encouragement at the ShutUp and Write sessions are invaluable. Prof. Dr Justo Bolekia Boleká, Prof. Mamadou Badiane, Prof. Adriana Mendez, Dr Sandra Hernández, Mr George Nimo, Miss Josephine Samani, Miss Edna Ovulley, Lawyer Christiana Awoonor, Laywer Emmanuel Amankwa, and Auntie Vivian Attah, Miss Thelma Quardey, Miss Miniruwan Samarakoon, Mr Edward Johnson, Miss Adobea Owoo, Miss Fafali Ivy Owusu, Miss Charlotte Ardey, Miss Sabina Hutchful, Miss Wendy Abbey, Dr Stella Makafui Yegblemenawo, Dr Seth Tweneboah, Dr Dorcas Dennis, Dr Comfort Max-Wirth, Dr Evelyn Yamoah, Dr Frederick Agbemade and Dr George Aberi deserve a special mention.

I am also very grateful to Dr. V A. O. Lamptey for supervising my Master's dissertation and introducing me to possibilities of research on Ghana and Cuba. I am 
particularly grateful to him for his counsel and for opening my eyes to "los matices y las franjas almacenados en la lengua pedestre.” Gracias Doctor Lamptey.

This journey is not complete without the smiles and encouragements from Abigail, Kekeli and Kenny Graham, Maud and Dr Fred Acheampong, Suzy Atsu-Dogbe and Mawuko, Mrs Admire Memuna Barnes-Jackson, Mrs Christiane Ker and Dr Alastair Ker, Dr Eric and Dianah Boamah, Mr Osei and Freda Osei, Dr Emmanuel and Mrs Olivia Yamoah, Dr Emmanuael Ikechi, MaameDuraa and Kobby Antwi-Boasiako, Dr Tosin Popoola, Dr Patrich Coelho, Dr Jon Preston, Dr Evelyn Yamoah, Miss Fafali Ivy Owusu, Miss Winifred Bentsil, Miss Maureen Mwangi, Dr Mark Toomer, Xinqi (Aileen)Wang, Solomon Opare, Marisa McPherson, Chizo and Oyinka.

To Pastors Peace and Willard Katumbu and the family of Christ for Salvation Ministries International, New Zealand I express my deep and heart-felt gratitude for the warmth and deep sense of belonging they provided me throughout my stay in New Zealand. I also sincerely appreciate Rev. Boamah and Rev. Mrs Agnes Phillips of Legon Interdenominational Church (LIC), Ghana for their prayers and support.

To you all I say, Akpe na mi, Merci Beaucoup, Feichang ganxie nimen, Muchas gracias. 


\section{Contents}

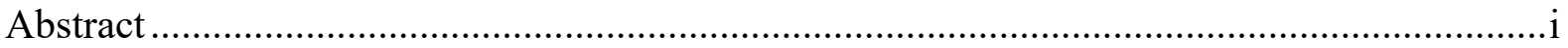

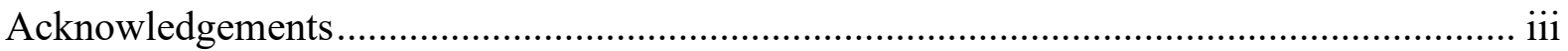

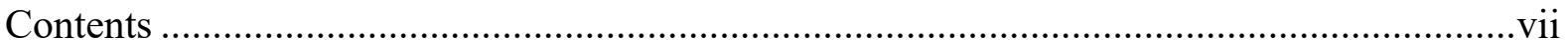

CHAPTER 1

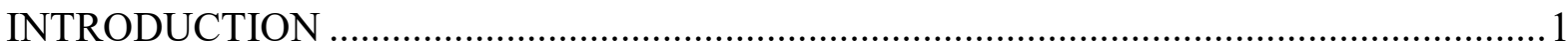

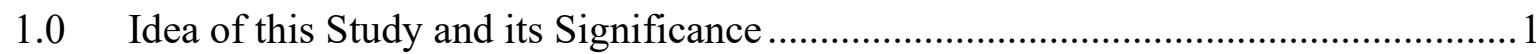

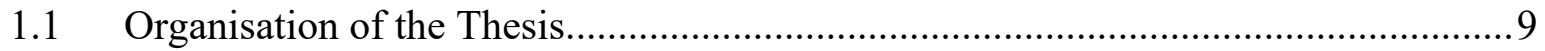

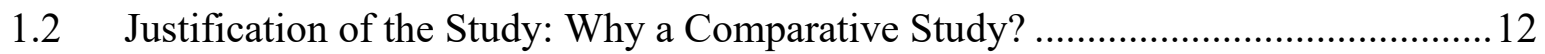

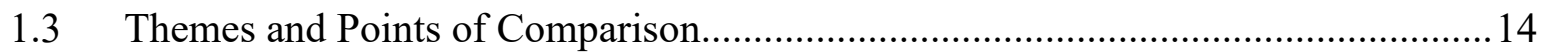

CHAPTER 2

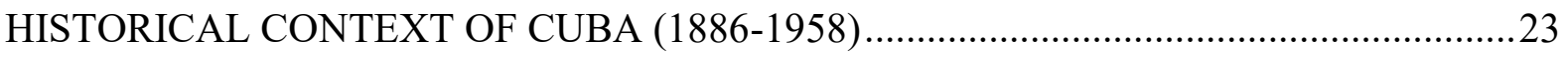

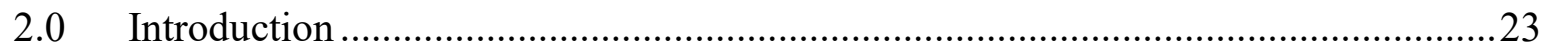

2.1 War of Independence, US Intervention and the Contribution of Blacks .................23

2.2 Discrimination against Blacks in the Post-Independence Period ................................30

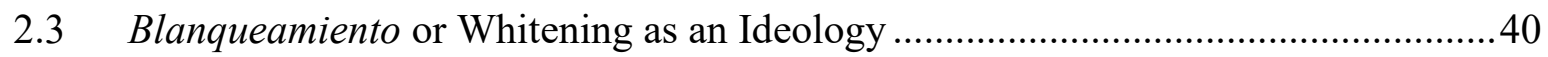

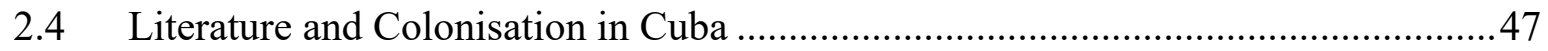

CHAPTER 3

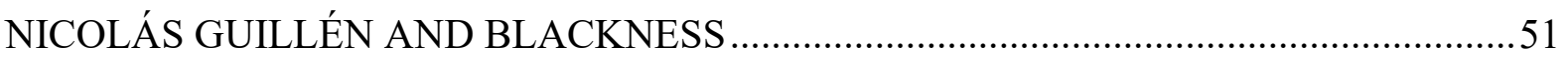

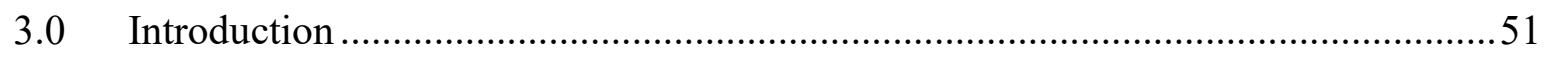

3.1 Blackness in Latin America and Cuba .................................................................... 51

3.2 Guillén's Experience of Discrimination and His Entry into the Debate on

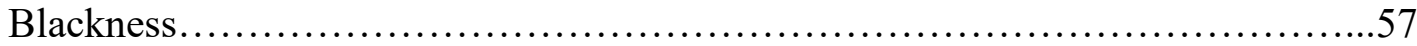

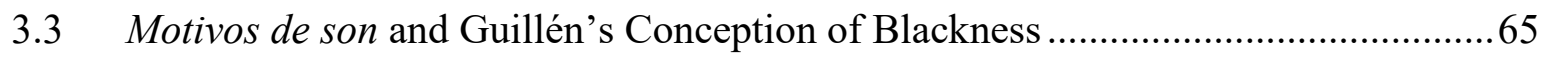

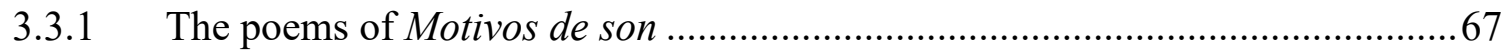

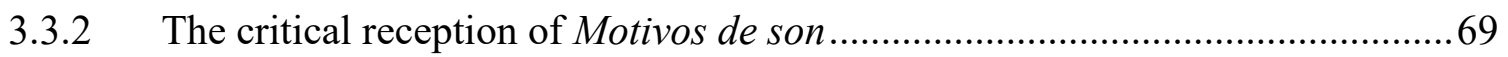

3.3.3 Guillén's conception of Blackness in three poems from Motivos de son ..........71

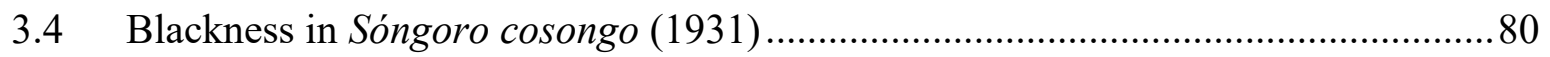

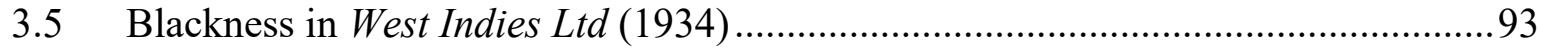

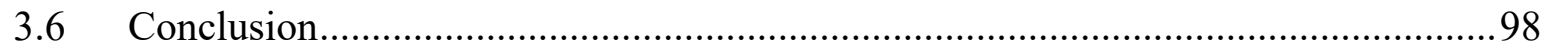




\section{CHAPTER 4}

THE REPRESENTATION OF WOMEN IN GUILLÉN'S POETRY ................................. 101

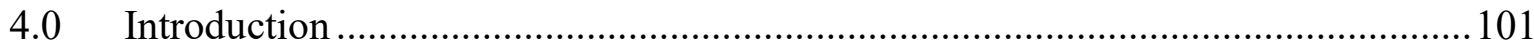

4.1 Women in Cuban Socio-political and Literary Contexts of the 1920s and 1930s .. 101

4.2 Critical Views of Guillén's Representation of Women in Motivos de son ............. 107

4.2.1 Critics of Guillén in relation to women in Motivos de son ...............................109

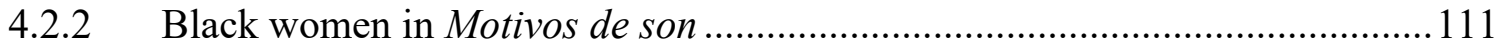

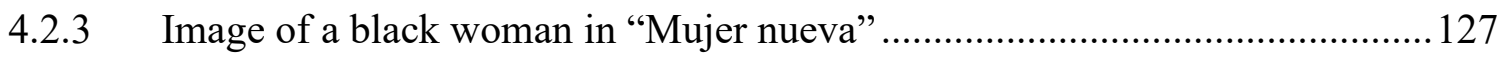

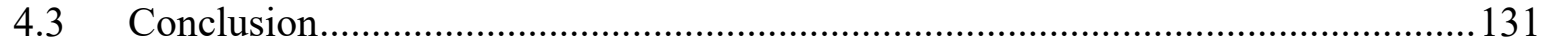

CHAPTER 5

INTRODUCTION AND HISTORICAL BACKGROUND TO THE STUDY ON

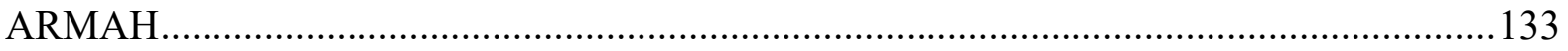

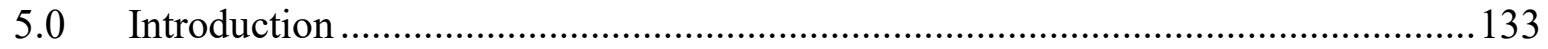

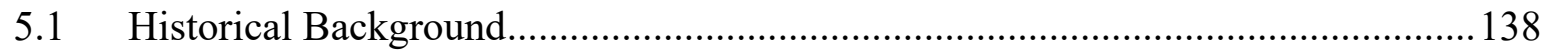

5.2 Fictional Representation of Ghana's History in The Beautyful Ones. ..................... 150

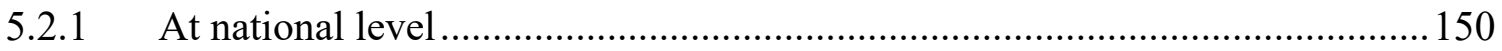

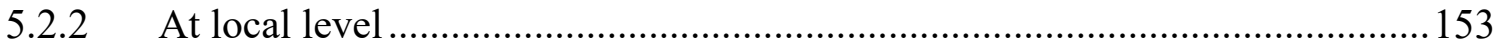

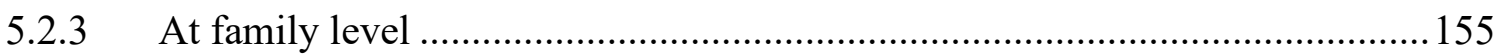

5.2.4 The Man (at the level of the individual) ......................................................... 157

5.3 Locating The Beautyful Ones in its Critical Context ........................................... 158

\section{CHAPTER 6}

THE MAKING OF “THE MAN" AS AN ICON OF REGENERATION AND RECONSTRUCTION OF GHANAIAN NATIONAL IDENTITY TRAITS....................... 165

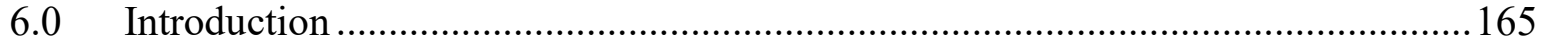

6.1 The Making of "The Man” as an Icon of Regeneration ......................................... 165

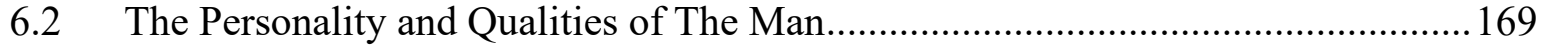

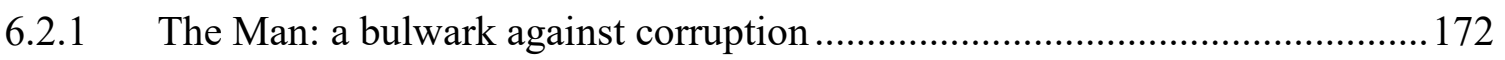

6.2.2 The Man as an embodiment of sobriety, responsibility and reflexivity .......... 175

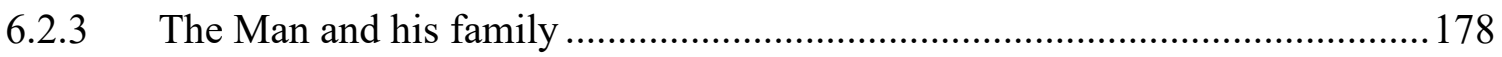

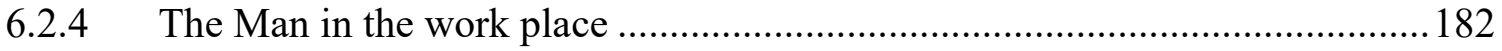

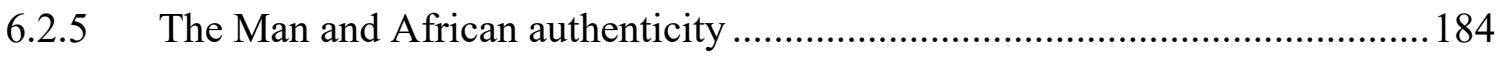


6.3 Symbols and Indications of Regeneration and Regrowth of Ghanaian Identity in The Beautyful Ones Are Not Yet Born.

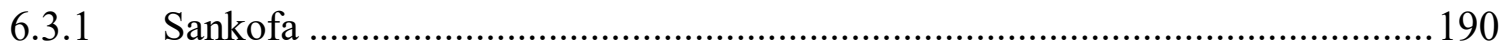

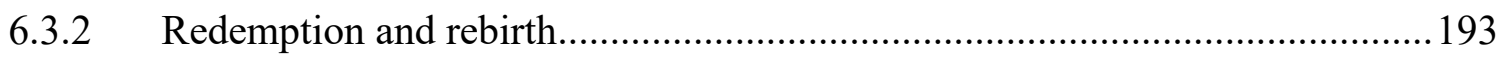

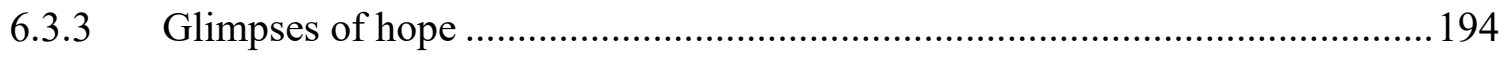

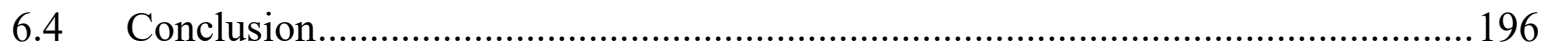

CHAPTER 7

REPRESENTATION OF WOMEN IN ARMAH'S THE BEAUTYFUL ONES ARE

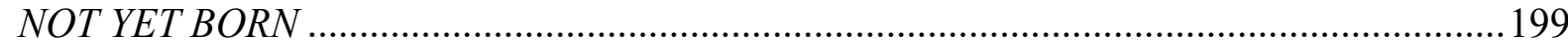

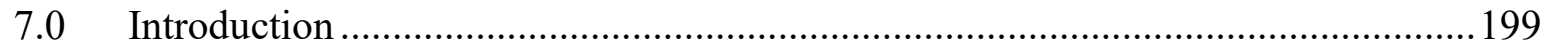

7.1 Armah's Representation of Women in the Context of The Gold Coast and

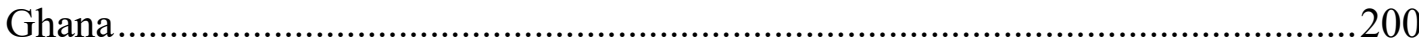

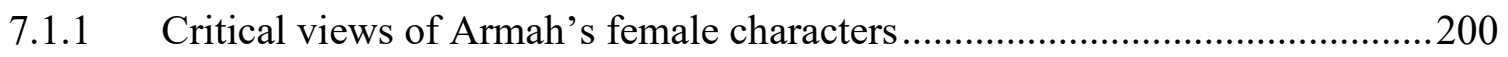

7.1.2 Historical and traditional context of representation of women.......................202

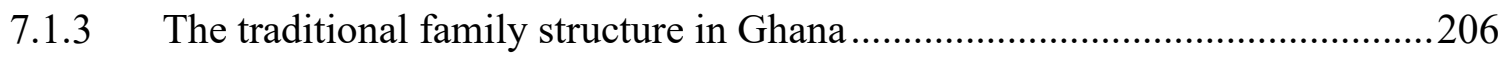

7.2 Representation of Ghanaian Women in Literature and in The Beautyful Ones ......209

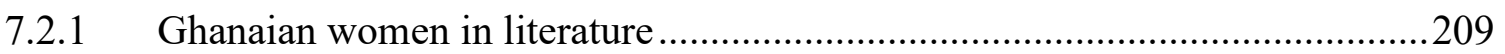

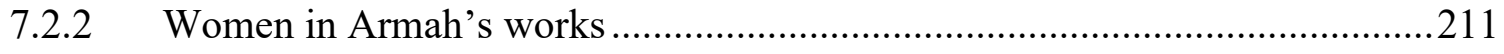

7.2.3 Women in The Beautyful Ones ...................................................................2. 213

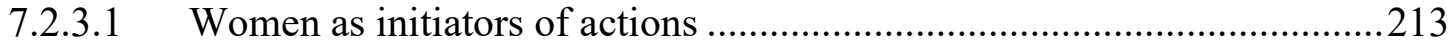

7.2.3.2 Women as emotional and moral supporters .........................................215

7.2.3.3 Women as prophets and sources of knowledge .....................................218

7.2.3.4 Women in the family (Wives and Sisters) ...........................................221

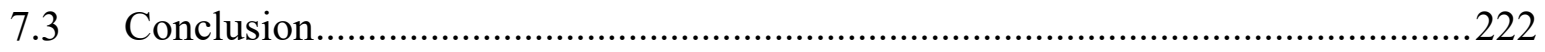

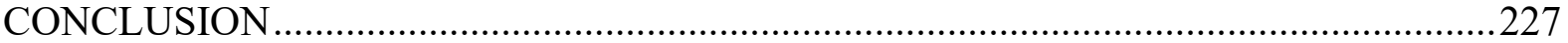

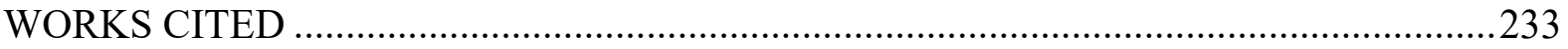




\section{CHAPTER 1}

\section{INTRODUCTION}

\subsection{Idea of this Study and its Significance}

I was introduced to the poetry of Nicolás Guillén in the final year of my studies at the University of Ghana through a course specifically designed for students who were not able to go on a one-year Study-Abroad programme in Cuba. This elective course introduced us to themes relating to post-colonial Cuba. I became fascinated with these themes because they were similar to many expressed in Ghanaian literature, particularly in the works of Ayi Kwei Armah. A guest lecturer, a Cuban woman, further asserted the similarities between Cuba and Ghana stating that Cubans consider themselves free people, without prejudice against any other people. There is free movement of people in Cuba, as there is in Ghana, she observed (Personal communication).

Fortunately, in the second semester, we had the opportunity to continue this elective class this time with a male visiting lecturer. There was every indication, from his appearance on the first encounter, for us to believe that he was a Ghanaian. The guest lecturer for the first semester was what we considered "White" but the one for the second semester was "Black". I mistook him for a Ghanaian because during the one hour or so that he spoke to us on the first day, he was smiling, nodding his head and making certain hand gestures which seemed to be typical Ghanaian mannerisms, so we thought he was understanding us as we spoke in "twi" and "ga" to him. Unaware that he spoke neither English nor a Ghanaian language, it was only when we started citing examples of the things he was talking about in the Ghanaian languages above that he said: "[N]o entiendo, soy cubano." It dawned on us that he was a Black Cuban. This was my first experience of a country with citizens who have very different shades of skin colour. "What historical occurrences would have caused these marked 
differences?" I asked myself. "And how do these people relate to each other in terms of racial attitudes?”

I decided to find out more about Cuban history and Cuban identity. This led me to carry out research on the national poet of Cuba, Nicolás Guillén. I was particularly interested in how Guillén represented Blacks and Whites in his work and, especially, how he presented the issue of the double identity of Cubans in his pre-revolutionary poetry. More importantly, I wanted to find out how common Ghanaian literary themes, especially those of Armah's works that I had read, could relate or correspond to themes I noted in the work of Guillén. My first reading of Guillén's Motivos de son and West Indies Ltd. pointed to his concern with issues of daily subsistence, poverty, racial prejudice, his dissent from widely held ideas about concepts such as racelessness, and his disappointment with the independence experiment. Many of these are similar to issues that Armah addresses in his first novel, The Beautyful Ones Are Not Yet Born. This deepened my curiosity and my desire to find out more about these two writers.

Inspired by this curiosity, I decided that at the appropriate time, I would ask the two lecturers separately how they felt about issues of race and cultural identity in their country. Later in the month, during a separate conversation with both lecturers, I learned something about them that shocked me. Each of them wished that the issue of race were not important, and that there were no need to refer to Black Cubans or White Cubans. The Black Cuban told me that Cuba belongs to them, the Black Cubans. Even though history has changed many things in Cuba, he still did not recognise his white compatriot as Cuban because of her colour. For her part, the White Cuban also emphasised the fact that Cuba belongs to the original owners and discoverers of the country and these are the White Cubans (ignoring the indigenous people, the Taíno). To her, Cuba can only be referred to as such because White Cubans live there: Cuba without them is not Cuba. This was my first taste of the ongoing 
force of sharp divisions and strains between the races in Cuba, the remnants of colonialism and imperialism that have led to the compartmentalising of races into shades of colour.

A second incident happened later in the semester with another friend of mine, who is a Cuban-American (his father is a Cuban and his mother American and he was born in New York). He came to Ghana on a semester abroad and was seen to be spending more time with the Black Cuban than the White Cuban to the extent of sometimes making negative racial statements about his white compatriot. At that point, I realised how deeply racial inequality and distrust have been allowed to grow roots in Cuba from the time of independence until recent history.

On another occasion, I was again shocked by the sexually derogatory comments the two male Cubans made about the Cuban woman when she was not there. The comments they passed led me to believe that the myths about female sexuality and its representation by AfroAntillean writers were still relevant. I therefore decided to re-read Nicolás Guillén's work to discover how he expresses the issue of race in Cuba and how he portrays those who are considered as "Others": Blacks, poor coloured people of mixed race (mulatos) and women. Since by then I had developed an interest in both writers, I decided to compare them on a larger scale of study to investigate how they represent the issues of their societies and which issues they consider most important.

The works of Armah and Guillén exhibit highly distinctive creative sensibilities and thus critics have often focused their analyses on their expressive writing styles. However, in addition to their styles, this thesis looks specifically at the socio-cultural and political issues that were current at the time of the publication of these works, and to which they were responding. Both writers represent crucial moments in the socio-cultural history of the people of Cuba and Ghana in their works. Cuba is characterised by ethnic, racial and cultural diversity, while Ghana too is home to various ethnic groups with distinct cultures but is not 
racially diverse. This comparative research will also enable us understand the similarity or otherwise of the representation of post-independence national identities of Cuba and Ghana in the works of these writers.

This study contributes to the growing body of research on the connections between African and Latin American studies. In particular, it explores the interface between Ghana and Cuba in post-colonial times. Several studies in International Relations have looked at the Economic and Trade collaborations between Ghana and Cuba but no study has compared the literary representation of the socio-cultural and political situations of these two countries, even though they share similar histories of colonisation and cultural development.

My thesis will also contribute to the scholarship on Armah and Guillén's works. In particular, this study re-reads both The Beautyful Ones by Armah and Motivos de son, Sóngoro cosongo and West Indies Ltd. by Guillén, in terms of their treatment of the representation of women, the challenges of post-independence, poverty, Black self-respect and pride, Blackness, and collaboration and cooperation between the races respectively.

This study also has theoretical significance. The comparative model of literary analysis is mostly conducted between different classical European languages such as Latin, French, English and so on with the aim of locating the influences that these languages, or aspects of these languages have on each other. However, it has progressively opened up itself and broadened its scope to include other languages, cultures and genres. It is in this spirit of a broadened scope that this study adopts the comparative study model and applies it to two different genres: poetry and the novel. The thesis also compares across languages — Spanish and English - and, by using close textual analysis, examines post-colonial representations of notions of racial and national identity in Cuba and Ghana. It looks at race not only in terms of the categories of White and Black, but also at the variations and distinctions within these categories. This thesis views the Caribbean racial legacy from Africa as important and 
positive, but also examines Black misogyny and self-abnegation. It points to the ongoing presence of racial shame but also to indications of hope and change. It engages with the failures and disappointments of decolonisation as reflected in the work of two writers who are determined to probe behind the clichés of liberation ideology.

Ultimately, my examination proposes a re-reading of both authors' works. That is, I will argue that Armah's work offers us a vision of the regeneration and regrowth of Ghanaian society as seen through the main protagonist, The Man. Through the main character, Armah represents the "beautiful ones" that he anticipates will be born to enable the nation of Ghana to start experiencing good governance, proper social services and equal pay for equal work done. That is, through these figures, the nation will finally realise the hopes of independence. He also puts forward a more empowering representation of women not only as wives and as supporters (moral and emotional) of their men, but also as initiators of actions. Guillén's work is also shown to offer a more progressive and positive representation of women than was the norm in Cuba at the time. In addition, departing from the debunking of old and unprofitable myths about Blackness and challenging the unrecognised position of Blacks in Latin America in general and in Cuban society specifically, Guillén dispels, as Clement A. White argues, "many of the falsehoods about the (Black) race through a positive literary portrayal" (15).

I compare these writers because both are engaged in what I view as a similar project: that of identifying the challenges of their societies in the time after independence and putting forward various means of addressing these issues in their works, including disrupting the social structures that supported inequalities, while refusing to become immersed in the criticisms and controversies generated by their works. They both draw on the past experiences of their nations and cultures in order to project a better future for their nationswhat I will refer to as the process of sankofa in Armah's case. Guillén asserts the rights and 
privileges granted all Cubans by the Constitution of 1901, especially Cuban Blacks, while Armah asserts African traditional and moral values as key ingredients in the way forward to the healing of the ills of post-independence and towards the consequent regeneration of his society.

In highlighting the challenges and complexities of their post-colonial setting, both writers, I argue, fulfil the role of the "engaged writer" as originally articulated by Jean-Paul Sartre in his introductory remarks to Les temps modernes in 1945, and later explained by Charles Whiting in 1948. Guillén and his work dealt with in this thesis, of course, predate this concept, however, he seems, according to the arguments of this thesis, to be applying the principles of an engaged writer in his work before the term had currency.

The psychoanalyst and European cultural and intellectual historian, David James Fisher, introduces the first chapter of his work on Romain Rolland and the Politics of Intellectual Engagement (1988) with Jean-Paul Sartre's definition of an "engaged writer" thus: "I shall say that a writer is engaged when he tries to achieve the most lucid and complete consciousness of being embarked, that is, when he causes the engagement of immediate spontaneity to advance, for himself and others, to the reflective" (3), pointing to the crucial role of the writer as an initiator of communal reflection and action. Whiting explains Jean-Paul Sartre's initial concept of an engaged writer, or engaged literature, as the intentional responsibility that a writer exhibits towards the happenings of his society (84). This responsibility resides in his being able to articulate both the pleasant and the unpleasant aspects of his society, just as Armah and Guillén do, but in a subtle and an ambivalent way. Whiting further argues that "the great social and political questions of our time should be the concern of every member of society" and as such, "we [writers] can no longer afford to ignore such problems but must seek to meet them face to face and contribute in whatever way we can to their solution" (84). The importance of engaging with one's society in order to 
change it is stressed here: "[T] he very raison d'être of engaged literature lies in the possibility and expectation of change" (87) and I compare Armah and Guillén on this basis.

Scholars like Fisher, as well as Micheline Tison-Braun, have associated the engaged writer with humanist attributes, arguing that s/he should first be an advocate and, secondly, be mostly preoccupied with the fundamental questions of national development and the purpose of this development (Fisher 4). Armah and Guillén are considered in this thesis as advocates who are preoccupied with the developmental issues of their nations, and who manifest their disgust and disappointment at the slow implementation (or abandonment) of the laudable ambitions of independence in a subtle and sustained manner in their works.

Robert July, a scholar of African history and society, and Kofi Anyidoho, a Ghanaian scholar, have taken up the idea of an engaged writer in their works. Robert July suggests that in taking up his role as a humanist and committed writer, the artist "was observing and judging, admonishing and exhorting, and assessing the quality and the character of the world he lived" (47-48). With this assertion, he stresses that the artist must take advantage of his knowledge, which he owes to the "privileged" position he occupies in society, to question its ills.

This need to redirect society is also stressed in Anyidoho's work. He indicates that it is the "prerogative of the artist to publicly accuse his or her society of loss of proper sense of direction" (8). To do so, the engaged writer must not to be tainted by any political or social convictions to only partially report the "truth". As a conclusion to what the engaged writer of post-independence Ghana should do, Anyidoho proposes that these writers should keep "their creative stethoscopes close to the heartbeat and pulse of the nation as the people fumble and stumble, struggling and rising again, sometimes against the very laws of sanity and of gravity" (20). The medical language that Anyidoho uses indicates how crucial the role of the engaged artist is - he is the emergency "doctor" of society, needed to keep his society alive 
and well. Armah and Guillén both display such a sense of urgency towards the ills of their post-independence societies.

The concept of the engaged writer is relevant to Armah's and Guillén's work since they manifest the very raison d'être of engaged literature which lies in the possibility and expectation of change. Armah emphasises his role as a writer in his 1984 essay "Masks and Marx, The Marxist Ethos vis-a-vis African Revolutionary: Theory and Praxis":

If it seems incongruous that a literary scholar, a novelist, should choose to discuss revolutionary theories, praxis and worldviews, the incongruity lies solely in the inadequate education of the beholder. I am an African, an artist, a scholar. As far back as our written and unwritten records go, it has been the prime destiny of the serious African artist to combine the craft of creativity with the search for regenerative values. (35)

This assertion clearly underlines Armah's wider purpose, which, I will show, is similar to Guillén's general goal: a search for regenerative values to cure the ills of their postindependence societies.

On a broader level, in the face of the growing collaboration between nations, this work is timely for a better understanding of the relationship between Ghana and Cuba. It also seeks to capture relevant historical details that might generate debates and connections between these countries and to foster an exchange of ideas in terms of their national experiences after independence. Cuba, since the revolution in 1959, has sought to export itself as a political model and has created connections with African countries in the areas of medicine, education, and economics. The connection and similarity between Cuba and Ghana is implicitly recognised in the African, Caribbean and Pacific Nations' (ACP) agreement of development and cooperation goals, discussed at the 2008 Accra, Ghana summit, "Promoting Human Security and Development" (www.acp.int). The 2019 ACP Day is on Friday, June 7, 
publicised under the banner: "The ACP Group—Deepening and Diversifying Partnerships", and is an apt expression of collaboration between nations. The ACP was established in 1975 to promote the underlying principles of cooperation between nations with similar visions and aspirations such as Ghana and Cuba. One of the main objectives of the ACP is the "consolidation of unity and solidarity among ACP States, as well as understanding among their peoples" and, it continues to this day to encourage members to engage with each other in terms of culture, politics, trade and economics. My analysis of the works of these two writers leads to further understanding of the cultural and social similarities between these two nations. In addition, the elaboration of thematic parallels and symbolic representations which transcend language (in the case of Cuba, Spanish, and in Ghana English), and other barriers like geography and historical period are a means of thinking comparatively about two countries rarely examined in critical, cross-cultural terms.

\subsection{Organisation of the Thesis}

My analysis in this thesis is structured as follows. Chapter 1 constitutes the introduction of this thesis, and gives a general background to the study. In it, I present how the original idea of this thesis came about and how it evolved. I also offer a justification of the usefulness of a comparative study on Armah and Guillén (despite their differences) and explain the various perspectives, contexts, differences, commonalities, blindnesses and opportunities from which the comparison is undertaken.

History plays an important role in determining the prospects and the future of all nations. Chapter 2 details the historical context of Cuba and shows that historical events, both traumatic and revolutionary, have had a negative formative impact on the cultural make-up of the nation at the time and have in turn influenced literary creation and interpretation. The 
chapter will argue that the lack of recognition of the role of Blacks in the independence wars, the phenomenon of whitening (blanqueamiento), the issue of mestizaje, the national rhetoric of racelessness and the continuing racial discrimination against Blacks during the postindependence period were significant phenomena in Cuban history. Their impact continued to influence the socio-cultural ecosystem of the country in Guillén's time, and indeed today.

The third chapter explicates Guillén's conception of Blackness and its implication for Blacks in Cuba at the time he was writing. Within the context of Latin America and with particular reference to Cuba, the issue of Blackness was central in the first three decades of the twentieth century, giving rise to calls for the recognition of the rights and roles of Blacks in Cuban society and a re-interpretation of the meaning and status of Blackness. Using poems from the three collections Motivos de son (1930), Sóngoro cosongo (1931) and West Indies Ltd. (1934), as well as other materials, I establish that for Guillén the issue of discrimination is real, fundamental and unavoidable; it is expressed in racial not cultural terms, as was sometimes asserted by those who espoused the doctrine of racelessness. He pinpoints the fact that Blacks have a role to play in "solving" the issue of discrimination by availing themselves of the opportunities for redress and by being proud and assertive. However, he also urges that Whites should recognise and grant Cuban Blacks the same rights and privileges as Whites, especially when the Republic already prides itself on its racial equality. It is important to Guillén to stress the issue of Black pride and assertiveness because the Republic had adopted a discourse of racelessness and, by so doing, had closed its eyes to the existence of deep divisions between Whites and Blacks.

The fourth chapter discusses Nicolás Guillén's rejection of existing dehumanising and stereotypical depictions of Black women. The chapter focuses on the empowering images that Guillén presents of Black women in his work and argues that his work of Motivos de son goes against the dominant masculinist and machista portrayal of Black women as sexual 
objects in Cuba in the 1920s and 1930s. A close analysis of Guillén's work reveals the complexity, nuance and perceptiveness of his regard of women and sexual relations in a culture where the need to assert male authority by disregarded groups leads to cruel and damaged sexual relations.

The fifth chapter introduces the historical setting of post-independence Ghana, the milieu from which Armah's work originates. It presents a history of Ghana that is pertinent to this thesis, locates the work of Armah in this historical moment, and offers an evaluation of how this historical context is represented at four levels of society, including The Man's personal level, family, local and national levels. This chapter also evaluates the critical context within which Armah's work has been analysed.

The sixth chapter will study Armah's first novel The Beautyful Ones Are Not Yet Born (1968). It focuses on the way in which Armah represents characteristics, values and traits that are relevant to the process of rebuilding and remoulding national morals and ethics after corruption and moral decadence had taken hold of Ghanaian society after independence. The chapter critically examines how Armah as an artist portrays the corruption and decadence of his society. As already indicated, he adopts the concept of the "beautiful ones" and fashions the typology of The Man, his protagonist, to suit this concept. The Man is an embodiment of a new set of attitudes and values that are a key part of the road-map to the rebuilding of the nation of Ghana. Specifically, I examine how Armah's work should be read differently—not from the perspective of it as a "sick book" as Chinua Achebe (24) referred to it, and the writer as a decadent preacher and prophet of doom, as has been asserted by many critics - but rather as the expression of a politically engaged writer who does not shy away from describing in detail the ills of his society and, through the characteristics and actions of a symbolic character, goes on to suggest solutions to these ailments. This interpretation seeks 
to refocus attention from the reading of The Beautyful Ones as replete with decadence and devoid of hope onto a more hopeful story of the post-independence society of Ghana.

The seventh chapter critiques the dominant views of the representation of women in Armah's work as confined to roles such as wives, sisters, prophets and parasites, and suggests that he, in fact, proposes a wider set of roles for women in The Beautyful Ones Are Not Yet Born. It extends women's traditional roles from emotional and social supports to more empowering positions such as initiators of action and as the store of knowledge for the family and society.

In my eighth and concluding chapter, I bring together my main findings on Armah's and Guillén's work. The conclusion evaluates the overall contribution of the thesis, emphasising its arguments, analyses and perspectives in relation to women and women's empowerment, to moral issues as they influence the socio-cultural fibre of the nations of Cuba and Ghana, and to how racial diversity and difference are handled in Cuba. It will stress how traditional African values of looking back to the past to recover essential and necessary tenets-sankofa - can help build the future of the nation of Ghana. In expressing their disappointment with the ills and challenges of their societies, Armah and Guillén, as engaged writers, also exhibit varying degrees of hope in suggesting measures to resolve these difficulties.

\subsection{Justification of the Study: Why a Comparative Study?}

The purpose of studying any phenomena (socio-cultural, literary or political) is to grant us an understanding of how things came to be as they are in order to comprehend how they might recur in the future. David Damrosch, in explaining what he calls the natural way of arriving at the distinctiveness of a culture, concludes that this process can only be attained when this culture is compared and contrasted with others (326), and this comparison should be based on 
individual distinctive features. Thus, the comparatist takes on the task of comparing various distinctions and permutations of difference within cultures. Damrosch emphasises that "the impulse to do comparative work remains, as it has always been, a generalising one: to look beyond a single context or tradition. Often in the past, though, generalists operated at a high level of cultural abstraction, taking little or no note of local research on works and on their cultures of origin" (329). Damrosch suggests therefore, that for such a study to be relevant, it has to go from general to specific as it progresses and must take into consideration local research and socio-cultural elements of the genres being studied.

At the early stages of the discipline of Comparative Literature, it mostly examined the exchanges and links between dominant European literatures. During the post-war period, there was the tendency to validate the speaking of several European languages as the preparatory tool for a comparative study. The linguistic and cultural scope of study has changed due to globalisation, with Asian languages also increasingly coming into play and the interaction of different cultures via new means of communication (Samovar et al., 57, Crayton and La Bella 63).

In comparing Armah and Guillén, who might at first glance seem to be very different and indeed unrelated, I bring together two writers who are neither students nor critics of one another. Nor are they products of the same canon of literature and, furthermore, these writers operate in different genres of literature - one (Armah) as a novelist and the other (Guillén) as a poet. This comparison draws attention to the value of looking at culture and literature to find unexpected correlations and connections. This work has come about because in my readings of the works of Nicolás Guillén, I have come to identify the fact that some of the issues that he dealt with in his poems are similar to the issues that Armah treated in his novels. As indicated by comparatists, this kind of study breaks linguistic, theoretical and socio-cultural boundaries and brings to the fore new trends and ideas about national 
literatures. As the Boston University Comparative Literature programme explains, comparative literary studies is "a fundamental project to cultivate reading across linguistic boundaries in order to highlight everything that the exclusive focus on a national literature tends to obscure. And even writers who knew nothing of one another may show fascinating similarities and differences" (www.bu.edu) - a statement which my thesis endorses, as this definition certainly speaks to Armah and Guillén.

In writing this thesis, I have read and considered applying a variety of approaches as I set out to understand and fully appreciate the selected works of Armah and Guillén. In the end, I have adopted close reading of the selected texts as part of the strategy and framework for analysis because it proved particularly effective in that,

i) It is a fruitful lens and basis for the comparison of the work of both authors.

ii) It enabled me capture the minute but very significant details that I might have glossed over had I adopted other strategies of analysing the selected texts of these two writers.

\subsection{Themes and Points of Comparison}

This project evaluates the representation of the deficiencies associated with the postindependence situation in Ghana and Cuba as presented in Ayi Kwei Armah's The Beautyful Ones Are Not Yet Born (1968) and Nicolás Guillén's collection of poems in Motivos de son (1930) Sóngoro Cosongo (1931) and West Indies Ltd. (1934). For Armah and Guillén, independence and the constitution respectively were expressions of an idealistic programme that finally disappointed everyone and the two authors propose paradigms for overcoming the negative legacies of this failure. Guillén proposes that for a unified nation of Cuba to be built, two things must occur. First, it must start by recognising that Blacks exist as a distinct and unavoidable category of citizens and as a particular sensibility shaped by specific histories 
that diminish their status, presence or even existence. Thus, he argues against subscribing to the concept of racelessness, and proposes that their distinctive culture has value. Secondly, they should be included in the national agenda because the position of Blackness and Black culture is an essential kind of unifying cultural force within the nation. Even though the potential and the relevance of this positive cultural energy had been lost after independence, it is only by recognising it and valorising it that the nation can move forward. In the case of Armah, the Black elites must awaken from their long slumber and be prompted to see the challenges of post-independence Ghana. From the discussions, it will become clear that Armah and Guillén undertake a literary journey of reconstruction and regeneration of the socio-political situations of their countries with differing degrees of optimism and from varying angles. Specifically, Armah suggests ways of rectifying the challenges of his postindependence society through moral and environmental uprightness and also by recognising and revalorising the roles of women in Ghana. Guillén, on the other hand, redefines the image of Black women and makes a strong case for the relevance of Blackness as a subject of crucial importance to the development of the nation of Cuba.

This analysis has selected the novel The Beautyful Ones and a number of poems in three of Guillén's earliest collections as the literary data for the comparison. The narrowness of the selection allows the concentration of general and deeply embedded issues of race, gender, identity and history in postcolonial nations to be thrown into sharper relief. In the works of these two writers, we clearly identify an important agenda, that of the authors' passionate search for unique cultural, political and social identities for their two nations after independence, in spite of the disappointments of independence. These works assert that, instead of the equality and prosperity for all that was the pre-independence expectation of the citizens of these nations, the opposite occurred. That is, the result of the independence process in both nations was unexpectedly negative. Armah depicts post-independence Ghana 
as beset with issues of lack of political will to execute the mandate of the people, sheer disregard of the needs of the masses, rampant cases of corruption of political appointees and the creation of a materialistic culture that stifles rather than promotes the development of Ghana. Guillén, on the other hand, depicts Cuba as not having fulfilled the promise of racial equality enshrined in the Constitution. On the contrary, what the country witnessed was an upsurge in cases of discrimination on the part of minority White and Black elites against the Black majority and poor whites. The Beautyful Ones depicts the misery and disillusionment under the civilian government of the first president of Ghana, Kwame Nkrumah, while Guillén's poetry depicts the rampant discrimination against Cuban Blacks and the disillusionment of Afro-Cubans in Cuba from independence to the late 1930s.

In addition, both authors put the search for a unique identity in a historical context: while Armah's work represents the era immediately after independence, Guillén's collections selected for this project portray Cuba in the 1920s and 1930s. As a result, in the case of Ghana, the thesis traces the genesis of this social and cultural identity deficiency from the time of independence and civilian rule to the concerns that led to the coup that overthrew the government of Kwame Nkrumah. In the case of Cuba, I trace the period after independence in 1901 to that of the writing of Guillén's poems in the early 1930s when the nation was still grappling with issues that had necessitated the initial fight for independence or were a consequence of it.

Most critics allude to Guillén's work as indicating an already achieved unity and living-in-harmony status of Black and White Cubans. However, it will become clear that Guillén appreciates that this was, in fact, not true. He emphasises, particularly in his essays of the time, the need for the recognition of the efforts of lower-class Blacks who were at the forefront of the fight for independence and who, after the attainment of this desired goal, were marginalised by their White compatriots. He stresses the need for more avenues for 
quick and effective integration of people from the lower-class level to the middle or upper class society. That is, Blacks and poor Whites should be able, without racial, administrative or bureaucratic barriers, to easily move into the same kind of jobs that others (those in privileged positions) enjoy. Guillén's call and emphasis here on equal opportunities is important in the sense that at the time, certain jobs were deemed to be the sole preserve of Blacks or Whites (Helg 118). In Guillén's view, for racial harmony to take root and develop in Cuba, both races should be able to legitimately carry out the kind of work they want to do and not be discriminated against because of their colour.

On the other hand, Armah's work proposes a different kind of approach to the situation of post-independence Ghana - an excoriating, detailed and painful exposure of the "decay" in morals and integrity of the upper class and the elites. His work ruffled the feathers of political leaders who were content with the political power they had and neither bothered about the needs of those who put them in power nor fulfilled the promises they made to the people before the elections. Armah's work is particularly important at this time because most writers of that era would not have dared to venture into political critique. Those who found themselves in this terrain would rather sing the praises of these politicians with the goal of attracting favour than criticise them or tell the truth about governance. However, Armah took a different trajectory. With the experience he had upon his return to Ghana after a period of study overseas and the bribery and corruption that he encountered first-hand, he decided, as an engaged writer, to expose the social, economic and moral ills of his post-independence society and propose a solution to the plague of corruption. Therefore, both Armah and Guillén write to expose the ills of their society, in the face of both the threats of the powerful and the optimistic rhetoric of postcolonial progressivism.

Guillén and Armah are also similar in vision as regards the kind of interaction they urge and write about between different sectors of society in their post-independence societies. 
In "Llegada" for instance, Guillén calls for the collective action of Cubans when he declares to all Cubans: "aquí estamos," "here we are". To him, Cuba can only develop as a society when it recognises and accepts that both Blacks and Whites are ineradicable parts of the Island state and they must help each other develop and, ultimately, develop the nation collectively. He calls for unity and collaboration and urges a unifying agenda from the top hierarchy to the lower echelons of power. Armah, on the other hand, believes that when The Man, who is at the lower level of society, understands the principles of integrity and hard work, he can easily pass it on to others at this level — thus, once the individual is positively influenced, the larger group will eventually be reached. Armah therefore, emphasises the importance of establishing accountability and integrity in the lowly-placed Ghanaian worker and the "trickle-up" effect it will hopefully have on the higher authorities. He again calls for responsible and reasonable leadership that will have an impact both at the lower and upper levels of the society. Once the "sons of the nation"- the post-independence African leaders - discharge their duties properly as leaders of the nation, the lowly-placed servant at the railway corporation, for example, will also be positively affected.

Armah and Guillén must be seen in the historical context from which they write. They write about their post-independence societies at the time when the citizenry were expressing the hopes, aspirations and desires that come with the recent achievement of political independence, and of the time after this achievement. Guillén's work, particularly the essay "El blanco: he ahí el problema," emphasises the disillusionment of the Black community in Cuba after independence because they have suddenly realised they are excluded from the benefits that should have accrued after the attainment of Independence. Thus, both write against a national blindness or complacency rooted not just in empire and white racism but also in post-colonial enthusiasm and revolutionary platitudes. 
These two writers display a unique ability to capture the socio-historical context in which they write - taking a realist approach to a shoddy and self-serving phase of national history. Armah's writing technique appropriately captures certain contextual and realist images of the post-colonial society of Ghana, mostly in the form of traditional and sociocultural elements, which are ultimately pointers to the muted but vital theme of regeneration that he suggests in his work. He addresses the issue of corruption (both moral and environmental) with detailed descriptions that sometimes repulse the reader and proposes solutions in terms of the qualities with which he endows his main character, The Man. The traditional relevance of family life and the relationship of the head of family with the immediate family, in terms of insistence on the accepted communal values, are also contextualised and emphasised in the work. The Man insists that, although his friends follow "the gleam," it is important for him to maintain his principles of moral integrity. Indeed, he reaps the reward of this stance at the end of the novel when his wife finally appreciates the tenacity and determination of her husband in keeping these values.

In addition, through Armah's description of the context of the interactions between The Man and his wife Oyo, and how they deal with daily issues, we realise that Armah stresses the value of patience, hard work and respect for the family-these are typical traditional Ghanaian values. Armah also attaches great value to the day-to-day relationship of The Man and his wife. Through their dealings with each other in the novel, Armah emphasises the value of domestic care and hospitality and the important role these play in the "real" life of Ghanaians. Another invaluable contextual detail that is depicted in Armah's work is Oyo's welcoming her husband home each day with a meal—-this she does whether she is happy that day or not - an emphasis on typical Ghanaian hospitality. I mention this detail here to emphasise the local context and the importance that Armah attaches to local items that are relevant in the rediscovery of the lost pre-colonial society. 
Guillén, on the other, hand in his process of re-evaluation of the Black woman, does not look far for elements that would facilitate this process; rather he portrays her in the domestic settings that all Cubans are aware of. She is portrayed in her day-to-day relationships with the Black men that she associates with. Indeed, for Guillén to be able to debunk the stereotypes that were associated with the Black woman, he needs to be context specific. Through his representations, we see that the domestic setting in which this Black woman is portrayed. She can be assertive and her lover should celebrate her for all her domestic qualities, her assertiveness and her vibrant energy. In addition, and more importantly, this Black woman should also be appreciated for her colour-her blacknessand not discriminated against, mistreated, or rejected in favour of whiter women.

Guillén also uses local and contextual elements and traditional ideas to represent the nation he anticipates and describes in his work. In his prologue to Sóngoro cosongo, the nation of Cuba is described as a "níspero", a "cóctel" and as a collection of "intertwined capillaries," as streams flowing into bigger streams, which are local metaphors that capture the lived experiences of those who live in Cuba. He decries the distorted raceless image that Cuba seems to portray of itself to the outside world - Cuban society is not as all right as it is portrayed to the outside media. He portrays the scarcity, economic deprivation, lack of opportunities and lack of appreciation that the Black woman and Black people in general face. He does not address the issue of corruption in politics, like Armah but rather emphasise the lack of appreciation and equal opportunities for Blacks. He stresses the barriers between Blacks and Whites and advocates for inclusivity. For him, the Black and White elements of Cuba should be recognised, their strengths and weaknesses unearthed and harnessed for the benefit of the nation of Cuba. In Guillén's poetic world, the bongó which produces the authentic son to which both Whites and Blacks respond, is an essential element that constitutes the nation of Cuba-it is important that this and other factors are recognised and 
used in the building of the nation. Therefore, an agenda of revalorisation is visible in Guillén's work as he seeks to present Black women and Black people in a more positive light and highlight the importance of Blackness and Black culture to the nation of Cuba.

In Armah's novel, workers like The Man find themselves in the minority in a culture where the majority of officials engage in corruption and misappropriation of public funds. As a typical reaction, he lives at the margins of society — not wanting to be part of the corrupt practices. Blacks' position in Cuban society, too, makes them a marginal group within a larger society. Many Blacks do not even want to associate with each other, as is depicted in some of the poems. Some of these Blacks, especially those who happen to be light-skinned, are highly placed in society or have good jobs, are perpetuating the stereotypical ideas and repressive dominant ideologies of Black inferiority and Black lack of solidarity against fellow Blacks.

Another level of comparison between Armah and Guillén is in their use of characters. They are realist in their portrayals-Armah does not use unrealistic characters, (although The Man is arguably a symbolic figure) and the same applies to Guillén. ${ }^{1}$ Both Guillén and Armah depict what White calls "the grim, ugly truth of hunger and abject poverty" (36), in Ghana and Cuba respectively. Guillén and Armah do not see themselves as judges, but rather, as White puts it in relation to Guillén, as "honest recreator[s] of the ambience of human despair, misery, and hopelessness, and in so doing [emphasise] the level of urgency of the situation" and hence the need for change (37).

Guillén's first work that brought him literary renown in 1930 was Motivos de son. Armah's first work The Beautyful Ones Are not Yet Born appeared in 1968, making a difference of thirty-eight years - two generations apart from each other. I decided to study

\footnotetext{
${ }^{1}$ This perspective is productively applied in Mirta Aguirre's argument about the characters in Guillén's work. The critic indicates, "[l]os personajes de sus versos se convertían velozmente en criaturas de carne y hueso... lo que sucede es que el poeta no inventa, sino que desprende de la realidad sus creaciones. Sus criaturas y la problemática de cada una de ellas existen" (18).
} 
these two post-colonial writers in order to explore the socio-political history of Ghana and Cuba, and, to my surprise, both share an experience of similar political and social events. What is more, their histories are linked with each other through practices and worldviews of the two societies. Above all, the authors are both post-colonial writers of African origin pursuing themes such as national identity after independence, social justice, proactive citizenry and the need to raise consciousness among the citizenry about historical antecedents that define present ways of life. Ultimately, both are seeking new paradigms to overcome the failures of the past, the disappointments of the present, and the as yet unrealised possibilities of the future. 


\section{CHAPTER 2}

\section{HISTORICAL CONTEXT OF CUBA (1886-1958)}

\subsection{Introduction}

This chapter gives a historical background to the poetry of Nicolás Guillén (1902-1989) outlining the historical contexts that are of relevance to this study. The chapter will examine ideologies and events that charactirise the period between 1902 (the attainment of formal independence) and 1958 (the year before the Cuban Revolution). It will also look at the cultural, social and economic aspects of Cuban society. This chapter will particularly focus on themes that concern this work, the Wars of Independence, the US intervention and the contribution of Blacks, independence and discrimination against Blacks, the ideology of whitening, and literature during the colonial and independence period in order to determine the extent to which they influenced the work of Guillén.

\subsection{War of Independence, US Intervention and the Contribution of Blacks}

Nicolás Guillén was born into a period of widespread disenchantment in Cuba with the nation's state of dependency on the United States of America. When the War of Independence against the Spanish colonialists ended, and was immediately followed by the beginning of the US military occupation in January 1899, the people of Cuba began to experience internal contradictions and confusion. According to Marial Iglesias-Utset, this transitional period in Cuba - "the twilight of one century" and "the dawn of another"-was "characterized by ambiguity" and occupied "an indeterminate middle space in the life of the country" (2). This was because, at that point, the nation could not be classified as "either a colony or a sovereign state". As Iglesias-Utset argues, "while the country had made a 
definitive break with its colonial past, there was little clarity or agreement about its future shape and direction" (2). He further stresses the ambivalent situation that Cubans had to navigate:

Against the background of the symbolic void created by the formal end of more than four hundred years of Spanish rule, a battle broke out among three segments of the Cuban polity: the proponents of a strident nationalism, the advocates of a forceful "Americanization" of Cuban customs and institutions, and the defenders of the Spanish cultural heritage, for whom the greatest threat was the powerful influence of the Anglo-Saxon model of modernization. (2)

As Andy Gravete indicates, American intervention ensured that in 1899 it was the US flag, not the Cuban flag, which was raised over Santiago. In June 1901, the US further strengthened their grip on the Cuban nation through the Platt Amendment, which empowered the US to intervene in any military activity in the country. This was a conclusive endorsement of American dominance over Cuba (14). ${ }^{2}$ Samuel Farber, in his critical assessment of the Cuban situation and the US's ongoing influence in Cuba since the Revolution of 1959, observes:

Although the Platt Amendment that largely subordinated Cuba to the US in a quasicolonial manner was formally abolished in 1934, this did not eliminate Cuba's political, economic and military subordination to the US. This new relationship, which lasted until 1959, was similar to the type of dependency that many ostensibly

\footnotetext{
${ }^{2}$ In their work, Cuba: A History (2010) Sergio Guerra Vilaboy and Oscar Loyola Vega explain the details of the various articles of the Amendment. Article III curtailed Cuba's sovereignty, giving the US the right to intervene in Cuba's internal affairs whenever it deemed this necessary. Article VII allowed the US to maintain naval bases and coaling stations in Cuba, either through purchase or lease. The Amendment also included specific military orders that specified other terms. One of these facilitated the entry into Cuba of US railroad companies, while another called for surveying formerly communal lands, making it easier for US investors to acquire land. They further allowed large US corporations to move into Cuba and a US naval base to be established in Guantánamo in the east of the island.
} 
independent countries in Africa and Asia retained with their former colonial master.

It was indeed a period in which Cuban sovereignty was, at best, precarious and the US reinforced their presence in all spheres of Cuban life.

Between 1902 and 1903, the US ended its military occupation of Cuba and Cuba became an independent republic — on paper, at least—with Tomás Estrada Palma as its first president but the US continued its programme of economic domination of Cuba. It was therefore, as Jorge Ibarra posits, not surprising that as part of the measures to directly and formally integrate Cuba into the economic system of the US, a trade treaty called the Reciprocity Treaty was signed in 1903 (1). This agreement allowed for a reduction of duty on products imported and exported between the two nations and set the tariff limits on certain products, including sugar (Dye 6; Morales Domínguez and Prevost 30). This treaty, however, had dire consequences for the nation of Cuba under Tomás Estrada Palma.

Estrada Palma's government experienced a wide range of difficulties and had to rebuild a nation destroyed by the independence wars, a nation in which poverty, unemployment, illiteracy and the results of the Spanish colonial government's neglect were evident everywhere. The government had to mobilise the few patriotic Cubans who were left in order to make the country as autonomous and self-reliant as possible within the narrow and unworkable limits set by the Platt Amendment (Pérez, "Structure" 129, Díaz-Briquets and Pérez-López 63). Leslie Bethell states that "the Platt Amendment denied the new republic treaty-making authority, established limits on the national debt and sanctioned North American intervention for the maintenance of a government adequate for the protection of life, property and individual liberty" (57). Bethell further indicates that the reciprocity treaties "not only bonded Cuba's principal export commodity, sugar, to a single market, the United States, but also opened key sectors of the Cuban economy-agriculture (especially sugar and 
tobacco), cattle-ranching, mining (especially, iron) ... and banking - to foreign, mainly U.S. control" (58). He also points out that within this period, while British and French investments stood at 60 million and 12 million dollars respectively, US investment in Cuba was around 200 million dollars (58).

According to Louis Pérez, at this crucial moment, the president needed to foster national unity around the "Cuban republican project" and achieve integration of the heterogeneous political sectors of the island, which was a difficult task ("Structure" 129). These were challenging responsibilities for his government, partly due to the opposition from the Cuban oligarchy whose members were content to occupy the space left by US capital when the US withdrew. In addition, many of those who took part in the struggle for independence, especially Afro-Cubans, considered the oligarchy's complete control of resources to be a social injustice (129) and demanded their "rightful share". The dependent nature of the Cuban economy also complicated the government's task, as the economy did not allow for new job openings and hence restricted growth and development (Vilaboy and Vega 45).

In 1906, José Miguel Gómez, a renowned military leader and former rebel led an uprising in Cuba against President Estrada Palma. The subsequent tumult and disturbances prompted the US to return to occupy Cuba. With the backing of the US, José Miguel Gómez and his liberal co-leader, Alfredo Zayas, won a landslide victory in elections held in January 1909 and the US for the second time withdrew its military forces (Pérez, "Army" 18, Domínguez and Prevost 31, Suchlicki 229). The Liberal administration of 1909 included well-respected patriots, and Cubans therefore expected them to do much more than Estrada Palma had done (Vilaboy and Vega 48). Furthermore, President Gómez was a leader of undeniable charisma: a farmer who had become a rebel major general and who was regarded as a true representative of the poor. However, Vilaboy and Vega point out that "almost 
immediately, José Miguel Gómez showed himself to be just the opposite" (48) and note that the Liberal administration from 1909 to 1913 became notorious for corruption, drawing on the Cuban treasury as if it were their own personal property (48). This period also saw an increase in world demand for sugar due to the failure of the sugar beet crops of Europe: this resulted in the "Dance of the Millions," a period of economic prosperity which led to a boom in sugar production in Cuba, alongside a proportional price hike in the world market (Gravete $5) .^{3}$

After World War I, the boom in American investment continued and Havana became an ideal destination for entertainment and illicit liquor and narcotics distribution (DíazBriquets and Pérez-López 83). According to Pérez, the United States directly involved itself in the administration of governance, influenced policy and determined the disbursement of public funds, while most peasants who took part in the independence war had lost their properties and did not have the necessary resources to restart their lives. Pérez explains that the US took advantage of the situation and brought in many artisans and craftsmen, land dealers and speculators (“Cuban” 195).

Pérez argues that the principal reason for the Cuban-American contact was that Cubans had tried to develop Creole identities that distanced them from Spanish culture. As will be seen later in the discussion, it was within this context that the plight of Afro-Cubans became a crucial subject. It was also the case that the sense of a Cuban future was nurtured, modelled and shaped by Cubans' encounter with the US. As Pérez argues, "the dominant facets of national consciousness were in formation, influenced by growing familiarity with a larger world in which North American usages insinuated themselves into émigré sensibilities" (“Becoming” 6-7). He concludes:

\footnotetext{
${ }^{3}$ During the period of the 'Dance of the Millions' the increase in world market prices for sugar was astonishing - from 10 cents in March, it increased to 18 cents in April, which further increased to 22 cents in May. The value of the sugar crop more than doubled from the previous year, from $\$ 455$ million in 1919 to more than \$1billion in 1920 (Pérez, "Becoming” 280).
} 
The experience was vital, for it enabled a great many Cubans to become familiar with the modern world out of which alternative ideological systems and moral hierarchies passed directly into what was then being assembled as Cuban. Process created memory, and some of the central sources of nationhood were derived from the experience in the North. (7)

The North American influence, as already stated, was prevalent in several sectors of Cuban life. Pérez, in examining the factors that defined and influenced Cuban identity, emphasises the degree of mutual influence of US and Cuba from the time of independence, Cubans and North Americans occupied a place in each other's imagination and in their respective fantasies about each other. They intruded in one another as the national character of each was in the process of formation, which is to say that they entered each other's national consciousness and henceforth, the character of each would retain permanent traces of this encounter. (6)

As will be seen in the thesis, some of the themes of the poems to be discussed are related to issues that developed out of this relationship between Cuba and the US. The alliance with the US contributed to the opening of the Cuban economy to the outside world, as Gravete indicates. This was therefore an opportunity for Cuba to develop in every sector.

However, things took a different course when the military overthrew Gerardo Machado in 1933 and in August of the same year, Carlos Manuel de Céspedes was selected to be the new President (Pérez, "Becoming" 264). A month later, on the evening of September 3, army protesters led by Sergeant Fulgencio Batista seized Camp Columbia and demanded a negotiation with the president, which ultimately resulted in a civil-military arrangement to bring Ramón Grau San Martín to power in September 5, 1933 for one hundred days (Pérez 267). Grau's government abrogated the Platt Amendment in 1933. This action incurred US displeasure and triggered subsequent propaganda and miscommunication 
to the military and civil societies such as the Asociación Unión Nacionalista, formed in 1927 , and the resistance group known as ABC Revolutionary Society formed in 1931.

As expected, in January 1934, Batista, with increasing authority and power and seen as a symbol of stability (Pérez, "Becoming” 277), overthrew Grau's government and put Carlos Mendieta in power as president. Subsequently, Mendieta resigned in 1935 due to a general strike and Batista put in place, for the next decade, "puppet presidents and shadow governments" to rule Cuba (Pérez 277). Miguel Mariano Gómez was installed as president in 1936 but, as was typical of Batista, he would oust Gómez and make Federico Laredo Brú president for four years, finally leading to Batista's own election in 1940. Defeated by old guard Ramón Grau San Martín in 1944, he seized power again through a military coup in 1952. Batista then ran for presidency unopposed in 1954 and ruled until 1958 when he was ousted in a military coup led by General Eulogio Cantillo who relinquished power to the 26 of July Movement and Fidel Castro became Prime Minister in February 1959 (Pérez 394-96).

According to Gravete, Batista in his shadow president position and during his own term of office elaborated his own ideology and development plans for the nation of Cuba (15). The Batista government exploited the boom in tourism to Cuba but the proceeds were not beneficial to the nation as a whole, instead going into individual pockets, as corruption was rife (Helppie 256, Farber, "Origins" 73-74). Consequently, as Gravete suggests, "the quality of life of the ordinary Cuban rapidly deteriorated" (15). Pérez describes the conditions in the early years of the Batista government as "the disruption of production at a time of indebtedness, and indebtedness at a time of destruction of property" ("Becoming" 194). These were the main political and economic events that characterised Cuba from its attainment of independence until the Revolution of 1959. Alongside these occurrences was the socio-cultural segregation of and discrimination against Blacks. 


\subsection{Discrimination against Blacks in the Post-Independence Period}

After independence in 1902, after three separate wars and an almost three decades of struggle, and amidst the rigours of the Platt Amendment and all its socio-economic and cultural implications, the Liberal revolutionary ideology was that "Cubans of all colours and social origins had created a formidable cross racial coalition and forged a nationalist revolutionary ideology that claimed all Cubans were equal members of the nation, regardless of race or social status" (de la Fuente, "Nation" 23). Contrary to this widespread nationalist revolutionary ideology however, the situation at the level of social reality was different as Afro-Cubans continued to be discriminated against.

It was during this period around independence that Afro-Cuban consciousness began to dominate the larger social discourse. As Aline Helg has emphasised, the role of AfroCubans as participants in the building of an independent Cuba, as well as agents of sociopolitical change during the critical process of transition from Spanish colony in the 1890s to a nation-state in the 1910s, was vital (2). According to Helg, Afro-Cubans could demand their "rightful share" in the affairs of the nation they fought for because they made up about one third of Cuba's population. She also notes that Afro-Cubans were able to effectively mobilise themselves in social, political and economic ventures and, on varying degrees of scale, unlike any other group of African origin in Latin America. Many joined the Liberation Army against Spain in 1895 and sought to contribute to the struggle, seeing their contributions as worth an appropriate reward after independence $(6,12)$. Helg maintains that the members of the Liberation Army who fought in the wars of independence had a clear objective: to have a republic in which everyone would respect the principles of reciprocity and subsistence (11). However, after independence, Afro-Cubans had to struggle for the realisation of most of their expectations (11). Helg argues that the shooting to death in July 1912 of Lt. Pedro Ivonnet, an 
Afro-Cuban member of the Partido Independiente de Color and one of the important figures in the Cuban struggle for independence from Spain who had stood for the hope of achieving improved Black political representation, on the pretence that he was trying to escape, reflected the tragic truth, that a decade after independence, Cuban society had not yet grappled with the issue of race and racial divisions (2).

Segregation of people of colour in Cuba dates back to the time of slavery. During the period of slavery, people of African descent, against their will, were forced to congregate in small groups called cabildos de nación-socio-religious and cultural mutual aid organisations with membership based on common ancestry (Falola and Childs 117). The elite and government officials established this institution in the sixteenth century regarding it as an outlet for the African-born slaves to release stress. Modern scholars take a different view, however. For example, Victor Anzoátegui sees the cabildos as places for keeping people safe (239) and Rebecca Scott considers them as avenues for self-expression but with a disadvantage of isolating groups of Africans from each other (266-67). Falola and Jennings suggest that the challenge of isolation, which may have led to limited participation in each group's activities, was resolved when groups of former slaves decided to pay slave masters in order to secure the release of slaves to participate in their events. They also indicate that some of the cabildos extended membership to people of other ethnicities $(13,130)$. The intention of the elites in forming the cabildos de nación to divide African-born slaves along ethnic lines was thus attenuated.

The elite however came to fear that the cabildos could become political institutions that would represent the social and cultural interests, needs and demands of the lower-class Blacks and would be difficult to disband. Another fear expressed by the elites was that the cabildos were highly organised, had access to vital information and good communication networks (Finch 162-63). Falola and Jennings note, "[t] he Captain General of Cuba attempted 
to prevent the establishment of an elaborate leadership structure" because of "the possible dangers of allowing slaves ... to create their own hierarchical structure" (133). Due to these mounting misgivings of the elite and government officials, the cabildos de nación, were officially declared illegal and prohibited from having their own system of government in 1888 (Ortiz, “Cabildos” 11; Falola and Jennings 133).

When slavery was finally abolished in 1886 , there were further reservations among the elites about the marginalised and exploited segments of society. These segments comprised dark-skinned Cubans (both Afro-Cuban Blacks and poor lighter-skinned Cubans [mulattos]). ${ }^{4}$ De la Fuente has indicated that many of this latter group moved to urban areas of Cuba in search of jobs but at the same time brought along with them their Afro-Cuban practices (110-15). As Robin D. Moore explains, most of these people did not have the skills and knowledge to compete with urban whites for jobs, and therefore, ended up being part of the large urban underclass during the economic depression of the mid-1880s (30). In the process of searching for jobs, both groups (Afro-Cuban Blacks and poor lighter-skinned Cubans) found themselves together and they shared ideas that gave them the capacity to adjust to the peculiar conditions of free people in a society that was still discriminating against people based on colour and class.

Most importantly, this contact brought about closer relationships among the groups as they participated together from time to time in communal gatherings called rumbas (Daniel 71). At these gatherings, they produced music and dance that served as an avenue to release their pains and disappointments, as a process of catharsis (Akombo 81). Although the rumba dance was created by Africans and their descendants, it was embraced by the section of the white populace who also belonged to the lowest levels of Cuba's colonial society. These white lower classes consisted mainly of Spaniards and their descendants who had relocated

\footnotetext{
4 "Mulatto" is the commonly understood term for a racially mixed person: either from the mixture of a white father with a black mother or a white mother with a black father.
} 
from the Cuban countryside to the city, as indicated already, in search of jobs. Like their African counterparts, they too found themselves alienated and displaced.

Cuba's independence had certainly, then, not resulted in a racially or socially equal Cuban society. The US military government's policies during the US occupation had immediately reversed some of the advances in race relations made during the independence struggles. For example, the transitional government had ensured that only white Cubans could be appointed to public office (Pérez, "Becoming" 322). Moreover, the Rural Guard and the municipal police forces that were formed in Cuba to protect US property in the rural areas had few Blacks members. Even worse, they were officially denied commissions in the newly created Artillery Corps and were also excluded from any meaningful political participation (323). Nevertheless, under the occupation government, the properties and privileges of the small former black elites were fully respected. The US authorities hoped that these elite Cubans would play a prominent role in the creation of the republic, and they gave them support and favour in the appointment to public office. They were a group that, according to de la Fuente, "might have been displaced by the victory of the revolutionary coalition," but, as a result of the intervention, was "guaranteed continued access to power". He laments this situation and concludes that it meant "independence had not been achieved" ("Nation" 24).

After several decades of being discriminated against by the elite in colonial Cuba, the Black masses protested. In 1906, the Blacks staged the August Revolution: the first violent manifestation of its kind against the unacceptable and fraudulent re-election of President Estrada Palma. In a violent response to the protests, the President masterminded the killings of the leading figures of the revolt, including General Bandera. According to The New York Times of 1906, Bandera's body was laid in the morgue in Havana with several bullet and 
machete wounds. ${ }^{5}$ In 1910, the government of the Partido Liberal (the Liberal Party) led by Estrada introduced an amendment to the electoral laws. This amendment had a twofold objective: firstly, to repress and mitigate the black revolt and, more specifically, to reduce the influence of the Partido Independiente de Color (PIC or the Independent Party of Coloured People); and, secondly, to inhibit the formation of political parties along racial lines. Upon the passing of this law, the government outlawed the PIC and its members had to resort to legal means to fight their suppression. Unfortunately, the judgment did not go in favour of the PIC. In protest, an armed uprising broke out in the region of Oriente (Pérez, "Lords" 76-7; de la Torre 105).

It is important to point out here that thousands of Cuban Whites, of their own volition, constituted "self-defence militias" and fought against the black protestors. Things were later to get out of hand when Black protestors were accused of committing acts of vandalism, destruction and set ablaze some houses, thereby igniting anti-black violence throughout Cuba. The anti-black violence resulted in the horrific bloodshed of May 31, 1912, in La Maya in which 150 black peasants (including women and children) were wounded and an armed conflict began (Helg 194-211). According to Helg, after two months of armed conflicts between the rebels on one side and the soldiers and the White armed groups on the other, the rebellion was crushed. She estimates the total number of Black casualties to be between 2000 and $6000 .{ }^{6}$ Helg further argues that, in terms of the destruction, an appraisal is impossible because many of the acts of vandalism and destruction attributed to the rebels either were exaggerated or fabricated (224-25). The crushing of the armed rebellion in Oriente in 1912 at the birthplace of Cuban independence sent a clear message that Black resistance to the status

\footnotetext{
${ }^{5}$ See The New York Times of August 24, 1906. It was reported that Bandera, the most daring insurgent in Havana Province, was put in the morgue alongside two other mulatto comrades, "all frightfully gashed by the long, heavy machetes of the mounted Rural Guards."

${ }^{6}$ For more on this, see Maritza Elias' interview with Eugène Godfried of Radio CMKS de Guantánamo in 2001 about the Massacre of 1912. She indicates that where were more than 3000 Independientes de Color who were executed.
} 
quo was no longer a valid option. Consequently, from the 1920s onwards, in individual and collective ways, the Afro-Cubans, who were also labelled as rebels, remained quiet in terms of violent political protest. However, they continued to practice the cultural traditions they brought with them from Africa (Clark 174, McAuley 183, Helg 246).

Nor did the events of 1912 deter Blacks from further taking part in more peaceful political activities in Cuba. Based on the provisions in the Constitutional Convention of 1901, which guaranteed universal male suffrage, an avenue was created for Black males to also take part in the elections. This also meant that, despite the existing prejudice against the Blacks, dominant political parties had to consider them in their campaigns and consequently compete for their votes. For example, some of these parties, in a bid to gain Black support, opened up positions specifically for Black Cubans who were interested in running as candidates (Abreu 30-1, de la Fuente 55-6). Nevertheless, due to continuing intolerance of Whites towards Blacks and their cultural practices even after the elections, the Blacks were forced to organise themselves into groups to avoid being attacked by the elites. Discrimination was rife in every sector of Cuban life from entertainment, club membership, theatres, sports, employment, and land ownership and even marriage (Helg 25-7).

According to Helg, "blacks and mulattos continued to be discriminated against in education" (25). Although public education in Cuba at the time was designated as an integrated system, private schools excluded black students, thus limiting their access to the universities. In addition, Cuban Blacks' access to public elementary schools was still restricted. Missionary schools, which were the preserve of some political leaders and intellectuals of the late nineteenth and twentieth centuries, also denied admission to Blacks (Pérez 66-8). Again, some highly prestigious American schools, such as the Ruston Academy and Cathedral school, accepted only white students, as did the Colegio Champagnat and the Colegio Belén (de la Fuente, "Nation" 145). Prisons and hospitals were also sites of 
segregation. According to Helg, "prisons and hospitals had one section for whites (including Chinese) and another for blacks and mulattos" (25). Moreover, "the Spanish officials continued to discriminate against the Cuban population of colour by crossing Don and Doña out of their identity cards and official documents," a practice she describes as symbolic of "the denial of full citizenship to Afro-Cubans despite the fact that they were full taxpayers" (Helg 25). Helg notes also that white women at the time were expected to marry within their race and class. It was only on rare occasions that there were unions between them and AfroCuban men as such unions were looked down upon, even if the black man was of a higher socioeconomic background than the white woman (27). Newspapers of the period were also replete with articles and editorials expressing racial discrimination. For example, an editorial in the Havana Sun in 1902 read as follows: "[T]he Negro thinks himself as good as the white man, and perhaps he is, but that is no reason why the white man should be forced to associate with him. ... There is no community upon the face of the Earth where an objectionable person would be allowed in either a hotel or a café. A proprietor has the right to reserve his table" (Cited in Pérez, "Becoming” 323).

Similarly, the following text was included in a 1908 newspaper column: "[T]here is no country where the white has done as much for the blacks. For blacks to be free ... many prominent whites struggled and died. Blacks by themselves would never have become free" (Cited in De la Fuente, "Nation" 46). De la Fuente similarly quotes Manuel Sanguily, a combatant in the Ten Years War, who argued that "we pauperized and ruined ourselves on their account; ... as Martí, who did so much for them, said, we suffered as they did, indeed more than they did, and bravely fought for our own liberty and for their manumission" (Cited in De la Fuente, "Nation" 29). Sanguilly concludes by demanding that since the "white race" brought dignity and elevation to the "black race", the Blacks should show gratitude to whites (Cited in De la Fuente 46). In another instance described by Helg, Sanguily in 1893 argued 
that even if it were accepted that many men of colour fought alongside the whites in the Revolution "the origin, preparation, initiative, programme, and direction of the revolution, that is the Revolution in its character, essence and aspiration, was exclusively the work of whites" (Cited in Helg 38-39). Thus, as Helg explains, white Cubans did not believe that black Cubans made any significant contribution to the revolution. ${ }^{7}$

The conditions of Afro-Cubans had deteriorated under the republic. On a visit to Cuba in 1905, Arthur A. Schomburg was quoted as saying, "during the colonial days of Spain the Negroes were better treated." He notes that Afro-Cuban Blacks "enjoyed a greater measure of freedom and happiness than they do today. Many Cuban Negros curse the dawn of the Republic." He goes on to state that even during the time of oppression and hardship in Cuba, black Cubans felt more welcome than they were when the struggles were over. The period of peace saw Afro-Cubans denied placements in jobs, ostracised and treated like political outcasts. Indeed, he stated, "the Negro has done much for Cuba" but "Cuba has done nothing for the Negro" (Cited in Pérez, "Cuba under" 150). Melina Pappademos insists that in politics, "Blacks' political authenticity, even their capacity to lead, was far more challenged and undermined than legitimated" and that even "when mainstream parties did slate black candidates for office, it was generally on the basis of their value for attracting black votes" (4). She argues that Blacks' political authority and their opportunities for advancement weakened under the weight of widespread racial marginalisation. In 1902, when Black veterans approached President Estrada Palma for equal access to government jobs, their request, according to Pappademos, "offended the president" (4). It was no surprise, then, that

\footnotetext{
${ }^{7}$ The discrimination that Afro-Cubans suffered is clearly depicted by the situation of Lt. General José Antonio de la Caridad Maceo y Grajales (1845-1896), a black hero and second-in-command of the Cuban Army of Independence (Foner 1) who, despite his position in Cuban society and in the independence army, was questioned on his political loyalty and integrity. Christabelle Peters argues that "despite his outstanding achievements, the dark colour of his skin made Maceo's fervid patriotism (in particular his rejection of the Peace treaty of Zanjón), plus his network of contacts, ... a cause for deep unease, even among whites sympathetic to the independence fight" (4). This discrimination against Maceo and the suspicion of his political objective culminated in him being "charged with harbouring designs for black rule", rumours that, according to Peters, "though not proven, persisted all the way up until his death in 1896" (5). See also Alejandra Bronfman Measures of Equality. Social Science, Citizenship and Race in Cuba, 1902-1940 (1-3).
} 
in 1910, the Morúa Law was promulgated. Through this law, Pappademos notes, "law makers sought to prevent not black votes but black (alternative) political mobilization" (4). Many of these issues continued into the 1920 s and the 1930 s when they generated widespread debate.

The need to address the racial discrimination and inequality in Cuba was highlighted in a speech delivered by J.B. Toscano, a prominent Afro-Cuban and an advocate for Black freedom in 1930 in Havana. He noted that "the oppressed races have to unite sooner or later in order to untie the knot of the rope that asphyxiates them" (Cited in McLeod 97). Toscano went on to argue, "[w]e do not want to be on our knees anymore and for this reason we rise up standing" (97).

However, Afro-Cubans were subjected to a form of "deep" stereotyping in the public sphere. Christabelle Peters summarises some of the characteristics of such stereotyping as follows:

earthiness and naturalness, ... reinterpreted to mean savage, backward, uncultured animalistic; a strong sense of cooking and eating, but not related to refinement; a way of speaking that is plain and unembellished translated in negative terms, to mean, "murdering the language" or forms of unintelligible speech, and a basic fecundity and liberated attitude towards matters sexual (reinterpreted, negatively, as a deficiency in the rules of sexual access, a failure to exert moral control, etc.). (28)

In the field of journalism, for example, black journalists were not well received in the mainstream press of the time. Reynold Peñales Moral tells his story of competing against all the odds to become a journalist in 1947 . He claims that in those days "they'd take on a black journalist to do a social column on the black societies, not to do them a favour but to attract black readers to that small space in their publications. Many weren't on salary. Blacks who trained as journalists and had the same qualifications with their colleague whites were not 
even employed" (44). He stresses that he persisted in his desire to be a journalist because he thought, "the situation of blacks had to change one day" (44).

De la Fuente discusses a key element that contributed to the prominence of race relations in Cuba. He indicates that during the period of the Republic, personal spaces such as schools, social clubs and other important places were considered to be strictly private and hence untouchable. He further argues that the implication of these private spaces is that discrimination and exclusion were made to appear legal since the state did not directly regulate how these spaces were operated. Nadine T. Fernández is of the view that the recognition given to and the legitimisation of the private domains affected Blacks' access to jobs and important social networks that operated in exclusive all-white clubs and schools ("Revolutionizing" 42). Significantly, "when the state did intervene, it was to consolidate and expand racial and ethnic divisions" (99). Many parks and recreational venues such as dance halls in Cuba at the time enforced segregation against Blacks to the extent that those working-class venues that did allow Blacks in, partitioned the dance floor into white and black sections. This partitioning is also seen in public school baths (Moore, "Nationalising" 38, Helg 97-99).

A growing social intolerance of Afro-Cuban practices and persecution of Blacks in general continued into the 1920s. The administration of Alfredo Zayas in 1922 prohibited Lucumi Afro-Cuban dances in the Republic. ${ }^{8}$ The edict prohibiting the dances stated that these dances were harmful to the public and did not enhance the moral values and civilisation of the people of Cuba (Moore, "Nationalising" 230). Hence, in 1925, the then President of the Republic, Gerardo Machado, agreed to a decree, published in the Gaceta Oficial de la República de Cuba, prohibiting Afro-Cuban public activities involving the use of drums and

\footnotetext{
${ }^{8}$ The arrival of African slaves from the northeastern Yoruba kingdom in Nigeria to Cuba is referred to as Lucumí. Its meaning extends to the groups of people who arrived and the religion they practised. For a more detailed explanation of the origin, development and expansion of Lucumi in Cuba, see Toyin Falola and Matt D. Childs's 2004 work, The Yoruba Diaspora in the Atlantic World (114-24).
} 
other instruments of African origin (Moore, "Nationalising" 232). Anthropological studies by prominent Cuban intellectuals of the Afro-Cuban culture at the time also did not help matters as they justified the suppression of Afro-Cuban culture. For example, Fernando Ortiz took up the challenge to study Afro-Cuban culture with the aim of helping to portray it more positively, in his 1906 work Hampa afrocubana: los negros brujos. However, he ended up on a trajectory that sought rather to modernise and inadvertently repress Afro-Cuban cultures in order to maintain the stability of the new Republic. According to Clement White, he (Ortiz) emphasised the cultural backwardness of Afro-Cubans as the cause of their slow move from lower social spheres to an upper one (13) and ultimately perpetuated the Republic's aim of cultural assimilation.

\subsection{Blanqueamiento or Whitening as an Ideology}

This section examines the ideology of blanqueamiento, or whitening, and explains its origins and socio-cultural implications for Cuba as a nation. Looking at the dramatic demographic changes of the nineteenth century in Latin American countries, and the peculiar nature of their newly gained independence, forming a national identity would pose some challenges to these nations, especially accommodating their non-white populations in the nation-building project based on European ideals of progress and race.

Since 1835, José Antonio Saco, acknowledged as one of the pioneers of Cuban nationalism, had maintained that the only viable means of incorporating Afro-Cubans into the eventual Cuban nation was through miscegenation. In correspondence to his friend, Gonzalo Alfonso, Saco pointed out that if the nation of Cuba was to locate itself properly in the sphere of nations it had no other option than "blanquear y blanquear" (Quoted in Duno-Gottberg 31). In the wake of the end of slavery in former British colonies in the Caribbean region in August 
1834, Saco called for a racial procedure, which he argued, would ultimately make descendants of Cuban slaves, citizens of Cuba. For this to happen, these descendants of slaves must first become lighter-skinned and do away with their African cultural practices. In his "Carta de un cubano a un amigo suyo," which was first published in Havana in 1844, Saco explained in detail how such a programme to racially and culturally "change" AfroCubans may possibly be integrated into the national project, with increased white blood helping to break down the barrier constituted by "la inmovilidad de la raza negra". He wrote:

Si los mestizos naciesen del enlace de blanca y negro, esto sí sería de sentirse mucho, porque menguando nuestra población blanca, la debilitaría en todos sentidos; pero como sucede todo lo contrario, yo lejos de mirarlo como un peligro, lo considero como un bien. El gran mal de la isla de Cuba consiste en la inmovilidad de la raza negra, que conservando siempre su color y origen primitivo, se mantiene separada de la blanca por una barrera impenetrable; pero póngasela en marcha, crúcese con la otra raza, déjesela proseguir su movimiento, y entonces aquella barrera se irá rompiendo por grados, hasta que al fin desaparezca. $(40-41)$

Thus, according to Saco, the Black race had to be urged to mix with the white race through the union of a white woman and black man in order to finally do away with the black race-a prelude of sorts, to racism and discrimination.

There was a strong link between whitening and the slave trade in Cuba. Many Cuban scholars of the late nineteenth century with abolitionist tendencies described these two forces (whitening and slavery) as a permanent problem. Luis Duno-Gottberg, in Solventando las diferencias: la ideología del mestizaje en Cuba (2003), argues that the aim of abolishing the slave trade was to "clean" the dissonant and dangerous elements in the patria: Blacks. Abolishing the slave trade would limit the perceived numerical threat of the Black 
population - a phenomenon designated as the black peril (De la Torre 100). For the Cuban intellectuals of the time, to enable lo cubano to be fully conceived and implemented, those ethnic elements that pose a threat to this dream [Blacks] should be "controlled":

Solventar la trata de esclavos es aquí disolver la presencia africana; es borrar un elemento "disonante y peligroso" en el seno de la patria. No responde exclusivamente al deseo de estimular la colonización con hombres libres debido a las necesidades de producción de la industria azucarera; responde también al proyecto de controlar la presencia de un elemento étnico que amenaza cierta concepción de lo cubano. (DunoGottberg 43)

For Cuban abolitionists, Cuba should not be like other plantation islands of the Caribbean with increasing numbers of Blacks, and introducing immigrants from the Canary and Balearic Islands and Ireland would resolve the problem. Antonio Benítez-Rojo suggests this explicitly:

$[\mathrm{P}]$ or el momento lo más urgente era evitar que siguieran entrando negros al país; era imperativo lograr el cumplimiento de los acuerdos para suprimir la Trata. Los ingenios y cañaverales no sufrirían la escasez de brazos, pues los esclavos que murieran serían reemplazados por colonos blancos traídos de Canarias, de Baleares, incluso de Irlanda con tal que fueran católicos; se casarían con negras y Cuba se blanquearía paulatinamente gracias a una política de continuos mestizajes. (206)

Thus, towards the end of the century, in response to a constant restiveness in many Whites about the possibility of free Blacks becoming a threat to society, Latin American countries developed an approach of gradually "whitening" their populations through interbreeding.

This process, however, "needed to be accelerated through the immigration of racially desirable people" (de la Fuente, "Nation" 46). De la Fuente further intimates that even though the whole idea of immigration was an attempt by the planter class to flood the market with 
cheap labour, "it [migration] operated under the racist assumption that only white labourers, preferably Spaniards, were congenial with Cuban civilization" (46). ${ }^{9}$ In his 1997 article, “Two Dangers, One Solution: Immigration, Race, and Labor in Cuba, 1900-1930," De la Fuente indicates that "close to 800,000 [immigrant] entries from Spain are reported by Cuban government sources between 1902 and 1931" (33). Cuba's white rulers also conceived this ideology in the first decade of the twentieth century as an economic policy for redistribution of land to white immigrants from Spain. According to Joanna Swanger, "[t]o Cuba's white rulers, the association of their country with blackness was troubling and the arrogance of the Platt Amendment was angering" (58) and with the policy of blanqueamiento, they "sought to tip the racial balance in favour of whites by offering land grants to attract white immigrants from Spain" (58). All of this ensured a gradual transformation of the native population "into a predominantly White European context" (González and Hughey 173), thus attenuating the numerical threat of the Black population.

The concept of blanqueamiento in Cuba at the beginning of the twentieth century also found expression in a cultural form based on the accepted view of Blacks' inability to move up the ladder of culture. This view was advocated by intellectuals like Martí and Ortiz, who maintained that "Blacks had the potential of being equal to whites but were 'stuck' in an earlier stage of cultural development" (De la Torre 104). Miguel de la Torre in La lucha for Cuba (2003) refers to Ortiz's view that “[t] he backwardness of blacks was not biologically inherited; rather, it was culturally based" and the only solution resides in its (the black culture) "assimilation to the 'superior' white culture through a process of de-Africanization" (104). Hence, according to him, "blanqueamiento, the whitening of Cuba, became a prerequisite for nationalistic advancement" (104). To back the racist theory of cultural evolution, a policy of racial fraternity and equality was advocated. Blacks needed to move up

\footnotetext{
${ }^{9}$ For more on how the immigration and migration policy was elaborated and promulgated into a working document see De la Fuente, A Nation for All: Race, Inequality, and Politics in Twentieth-Century Cuba (46-53).
} 
the ladder of culture in order to be at the same level with whites to take part in José Martí's “cordial republic with all and for all” (de la Fuente, "Myths" 27).

Lillian Guerra seeks to explain Martí's ideology in her work The Myth of José Martí: Conflicting Nationalism in Early Twentieth Century Cuba (2005). She opines that Martí emphasised the notion that whitening or becoming white can occur through culture and not necessarily by race. This argument may imply that anyone who adopts a particular cultural mode that is described as "white culture" automatically becomes white. For example, Martí endorsed an African society's decision to firstly "rescind their use of drums in rituals" and secondly, "to adopt literacy standards as requirements for advancing to higher status within the organization" (Guerra 34).

Further, Guerra defines this socio-cultural vision of whitening as "the process through which individuals and families had adopted the religious practices of Catholicism and the speech styles and cultural mores of the educated and wealthier classes in order to improve their social standing by becoming culturally more acceptable to white society and therefore racially whiter" (34). González-Sobrino Bianca and Hughey Mathew too define it as "the ideological and material process and practice of whitening or distancing Latin Americans from blackness, in other words, of "becoming white" (172).

Cuba is far from being the only example of such blanqueamiento. Other examples from Latin America suggest similar trends of the strong desire to whiten the populace or maintain racial purity and social status. Peter Wade highlights these two "wishes" in a study of Colombian racial history. Wade indicates that "in the obsessive concern with colour and status that characterised this sociedad de castas, only one thing was certain: to be black or indian was bad, to be white was good. To be rich alone was useful, but inadequate: to enter universities, the Church or the administration required proof of limpieza de sangre, clean blood and any doubtful heritage was a major obstacle" (61). 
Thomas Skidmore, using the case of Brazil, explains that the apparent acceptance of race mixture in that country could equally be equated with an endorsement of whitening because of a need to reconcile the emergent racist theories from late nineteenth-century Europe with the country's demographic history (136). Again, as Skidmore suggests, the "myth of racial democracy" is actually linked to the ideology of whitening, because it is based on the presumption of white superiority, thus maintaining the concept of an innate African inferiority. In addition, whitening is regarded as a purification process where the white factor dilutes the markedly black element and thus allowing the mestizos and Blacks to achieve an advanced state of civilisation (134-37). From the nationalist point of view, the project of whitening is a way of socially associating a particular label with an individual's position on the continuum from black to white (William Luis 398). The dictum "adelantar la raza" (improve the race) is commonly associated with the phenomenon of whitening (Rodríguez 155).

Unfortunately, in most Latin American countries, Blacks' response to such an ideology has helped maintain the nationalist discourse rather than promoting their interests. According to Miguel de la Torre, because of the privileges accorded lighter-skinned AfroCubans, "the desire was created in the minds of some Blacks to whiten themselves (usually by marrying whiter spouses) in the hope of achieving social advancement" (118) or to hide the African heritage in their offspring" (González-Sobrino and Hughey 172). They also adopted certain ways of life that are recognised by Whites as avenues of social mobility, education, for example. Harry Hoetink therefore sees the ideology of whitening and its effects on Blacks as "a manifestation of latent or camouflaged prejudice against Blacks" (10).

Related to blanqueamiento is the concept of mestizaje, often viewed positively. As a recurrent national trope in the nineteenth century, it was linked to the search for lo americano and underscored the constitution of the cultural identity of these nations (Martínez-Echazabal 
21). Mestizaje can be considered both a nationalist ideological process and a social phenomenon of mixture. Historian and cultural anthropologist Nadine Fernández remarks on these two representations of mestizaje as she indicates that in Latin America, the practice of "mestizaje has come to mean much more than just a physical mixing of the races. It is also regarded as a process of cultural amalgamation that is closely tied to nationalism" and to how categories like race, class and gender are manifested ("Race" 95). Vera Kutzinski describes the process of mestizaje as, "a peculiar form of multiculturalism ... a series of discursive formations tied to nationalist interests and ideologies $\ldots$ a multiculturalism that acknowledges, indeed celebrates, racial diversity while at the same time disavowing divisive social realities" (5). According to Peter Wade, when these two ideologies-whitening and mestizaje - are functional in a nation, they work to eliminate blackness and indigenousness in favour of lighter mestizos (357).

Wade explains the fact that there exists a well-established literature on race and mestizaje, which designates this term as "an ideology and practice of national and personal identity in Latin America" (360). In his 2004 article, "Images of Latin American Mestizaje and the Politics of Comparison," Wade emphasises that the mixture that results because of mestizaje cannot be put in a relation of opposition to racial absolutes (356). For him, "[m]estizaje, while it appears to erase origins and primordial categories of race and culture, actually continually reconstructs them. It depends on the idea of original or parent races and cultures to constitute the very possibility of mixture" (356). He underscores the fact that "[a]11 identities are constituted relationally and depend on others to exist, and mestizo identities are no exception. They may be deployed to different effects in different contexts, but to exist at all, they must invoke origins" (356). He again opines that when blanqueamiento and mestizaje are combined as ideologies of a country, as in Latin America, it becomes "a value- 
loaded process of the elimination of blackness and indigenousness from the national body politic in favour of whiter types of mestizos" and their effect depends on context $(357,361) .{ }^{10}$

The twin ideologies of whitening and mestizaje in Cuba prevalent in previous decades continued into the Revolution. According to De la Torre, José Elías Entralgo, a Cuban sociologist and proponent of Cuba's eugenics, in 1959, at the dawn of the Revolution, put forward his support for national integration through what he calls "mulattoization" and even "applauded the rape of African women by their White masters as the necessary evil of bettering Africans" (118). In today's Cuba, these two ideologies are still operational and mostly depend on the contexts in which one finds oneself.

The above explicates the genesis and implications of the ideology of whitening, how it manifested in Cuban society at the time and the general impact on the socio-cultural landscape of Cuba. The next section explores the type of literature that was produced in Cuba during the colonial, independence and post-independence period.

\subsection{Literature and Colonisation in Cuba}

The general political, social and economic conditions highlighted above stimulated academic discussions about how Cuban society could be improved in terms of the integration of the white and black elements and the building of a strong nation, which will have all the elements of lo cubano. A great deal of literature has been written that speaks to these conditions.

It is instructive that during the period of the conquest of Latin America, most of what was written as literature was in the form of chronicles and short stories about the conquest. Literature at this time mainly served the needs of the colonial masters as they, with the assistance of the elites of these societies, published works that projected and contributed to

\footnotetext{
${ }^{10}$ For more on the various evolutionary forms and newer definitions of mestizaje, see Peter Wade's "Rethinking Mestizaje: Ideology and Lived Experience," 2005 (239-57).
} 
the solid establishment of colonial society (Moraña 188, Moraña and Jáuregui 122). In the case of Cuba, the political conditions of colonial life made it difficult for most writers to stay in the country. For example, José María Heredia, whose poetry criticised Spanish rule, left Cuba in 1823 for Mexico to avoid being imprisoned, Padre Félix Valera had to go to the United States, and José Antonio Saco left Cuba after the Academia Cubana de Literatura, which he and his colleagues founded, was suppressed by the regime (Gray et al. 333, Muller 21, Branche 124). Jerome Branche indicates that even though the Captain General of Cuba Miguel Tacón suppressed the Academy at the time, its formation signalled the determination of liberal Euro-Creoles to express their opinions about art, politics and other subjects in an independent manner (Branche 125).

After the disbanding of the Academia Cubana de Literatura and the departure of José Saco, Domingo del Monte (1804-53), a well-travelled man with passion for literature, a polyglot, and "[r]ecognized as Cuba's first professional literary critic" (Branche 123), took over the organisation of young Cubans with literary aspirations. They often met in private tertulias in his home and constantly kept in touch with each other through exchanges of correspondence. Del Monte's philosophy, which became a watchword for the young writers, was that a poet

will consider himself a man and then a poet and in that way, will use all the strengths he can command to cooperate with the other artists and philosophers of the century who are worthy of calling themselves men; that is, those who have the spirit of men, and have in their breasts whole and malleable hearts, to improve the condition of their fellow men. (Cited in Ellis, "Cuba's" 28) 11 $^{11}$

Del Monte was also instrumental in organising other writers from within and outside Cuba to write on the subject of slavery. Due to his class and status in society as landed gentry, del

\footnotetext{
${ }^{11}$ For a detailed explanation of the role of del Monte and his literary tertulias in Cuban literary endeavours, see Branche's Colonialism and Race in Luso-Hispanic Literature (122-29).
} 
Monte was however, always careful about how he acted. He was particularly careful not to displease Mr. Madden, the British Representative in Cuba at the time (Henken et al. 295, Branche 125, 128-29).

In this period of censorship, most writers did not produce works that reflected the historical situation. ${ }^{12}$ Rather, most of them were deeply involved in romanticism and European forms of writing. It was only later in the 1880s that Julián del Casal and José Martí showed concern for and devotion to the Spanish-American issues affecting the island (Helmick 35-36, Valdés and Kadir 89). When the Wars of Independence intensified again in 1895, some writers were inspired again to write for the cause of liberation. They adopted mostly positivist attitudes to writing. For example, Enrique José Varona, the editor of Revista Cubana (1885-95), was a strong advocate for a scientific and sociological approach to literary activity stressing the necessity for writers to be aware of the events of their time. ${ }^{13}$ After the military action in 1898 and the US positioning itself in the affairs of Cuba, writers who had supported the struggles for independence became disillusioned. In this atmosphere of disillusionment, Pedro Henríquez Ureña — the Dominican Republic's philosopher and literary critic - made a visit to Cuba in 1912 to inspire these writers to engage with issues of national concern, which was not well received. Nor was Fernando Ortiz's brilliant exploration of the roots of Cuban society, a foundation for Cuban studies, studied by these writers (Pérez, “War" 34-5, Iglesias-Utset 86-7).

From 1913 to 1923, various literary styles and themes emerged in Cuba. For instance, the journal, Cuba Contemporánea attempted to capture the socio-political problems of the country but had little success. Other works of literature, like the novel, emphasised literary

\footnotetext{
${ }^{12}$ Even though some of these writers supported the massacre of the Conspiración de la Escalera of 1844, which resulted in the death of about 7000 Blacks, including poet Gabriel de la Concepción Valdés, and violinist and conductor José Miguel Román, their writings did not depict this. (See Murray "British Abolitionists in Cuba, 1833-1845" 108-109; Finch, Rethinking Slave Rebellion in Cuba: La Escalera and the Insurgencies of 18411844 (211).

13 See Cabrera Raimundo, Cuba and the Cubans (324). In this work, Enrique Varona is described as a man without academic degrees but a fine writer and a linguist.
} 
styles of parody and modernism. The Grupo Minorista, also called the protesta de los trece, later followed in these trends in their literary pursuits. (Moore, "Nationalising" 124-25, LynnStoner 88, Benjamin-Robert 58). These intellectuals pressed for reforms in the University and in the government of Alfredo Zayas. The group's aim included pushing for the correction of some of the wrongs of 1901 when the nation became independent. One of the most critical members of the group, Jorge Mañach used his writings to criticise the government and the republican constitution severely, referring to the constitution at one point as "that mockery of a republic, that illusion of a nationality in a colonized, humiliated people" (95). Overall, this period saw some attempts at assessing Cuban history and addressing issues of national concerns through the application of various literary styles. Yet, most of these styles emphasised arts for art's sake and vanguard expressions and hence ignored the "cultural interests of the large masses of Cubans" (Ellis, "Cuba's" 35).

These, in sum, were the social, historical and literary conditions of independent Cuba from 1902 to the 1930s. The situation of the next two decades before the Cuban Revolution in 1959 differed little from those explained above, concludes Helg in her work, observing that "although with time their efforts brought about the restriction of open racial discrimination, blacks' socioeconomic and political participation remained limited ... and even since the revolution of 1959" (247). The difficulties explained earlier contributed in part to the Cuban collective consciousness and "exercised in varying degrees some influence in shaping the terms by which national identity was transacted" (Pérez, "Becoming" 9). In addition to the socio-economic dynamics of the Cuban situation, "gender, class, religion and age differentials gave deeper complexity to the formulation of national identity" (Pérez 8-9). As will be discussed later in the thesis, the poetry of Nicólas Guillén would undertake the process of defining what the Cuban nation was in a bid to create an "all-inclusive" national identity. 


\section{CHAPTER 3}

\section{NICOLÁS GUILLÉN AND BLACKNESS}

\subsection{Introduction}

This chapter will examine Guillén's poetic representation of Blackness. It consists of six sections. Section 1 outlines the context of Blackness in Latin America with particular reference to Cuba, emphasising how crucial an issue it was seen to be in first three decades of the twentieth century. There were increasing calls for a project that would lead to the recognition of the role of Blacks and a re-interpretation of the issue of Blackness. Section 2 will discuss Guillén's views in his essays on racial discrimination. The following sections examine aspects of Guillén's representation of Blackness in a number of his poems firstly, in Motivos de son (Section 3), then Sóngoro cosongo (Section 4), and finally West Indies Ltd. (Section 5) and this is followed by the Conclusion in Section 6. The thesis considers only these first three collections because they constitute the primary poetic articulation of the ideas expressed by Guillén in his essays. In these collections, he articulates his vision of Blackness and the role that it must play in Cuban identity.

\subsection{Blackness in Latin America and Cuba}

From the 1920s, many writers of both Cuban and Latin American origins called for a reevaluation of the status of Blacks and Blackness. This necessity arose because Blacks were not given their rightful share of the privileges that accrued in these societies after independence. Many precursors and contemporaries of Nicolás Guillén focused on the issue of Blacks' status and portrayed aspects of Black culture and society in their works. Ramón 
Guirao, for example, completed a book of poems entitled Bongó. Poemas negros in 1934, and Órbita de la poesía afrocubana 1928-1937 in 1938 and Cuentos y leyendas negras de Cuba in $1942 .{ }^{14}$ For such writers, the position and image of Blacks, and the issue of racial prejudice had remained contentious and unresolved in Latin American society for a long time and, by the 1930 s and 1940 s, it was time to re-assess these issues. This re-evaluation would help to improve the status of the Black population in these societies and consequently would lead to a recognition of the part they had played in the development of the nations of Latin America.

Many critics have recognised the issue of race and its effects on Cuban society in particular. Jorge Domínguez, in his foreword to Carlos Moore's Castro, the Blacks, and Africa (1988) for example, observes that "the race factor has been of a decisive importance in Cuban history and that its workings led to a hierarchical system of subordination of Blacks" (x). This observation suggests that racial division was entrenched in Cuban society. Black political (electoral) support was only sought when there was the need for collaboration between groups on the island in order to break the hold of the USA. ${ }^{15}$ Thus, Afro-Cubans "gained increasing political and tactical importance in the eyes of Havana's policy makers" at the time of the fight for independence, for example (Moore 4). Duno Gottberg corroborated Moore's observation in Solventando las diferencias (2003) when he argued that after 1901, "la posibilidad de articular el mito de la igualdad racial en favor de la población afrocubana tuvo importantes consecuencias en el desarrollo de la política electoral cubana" (Duno Gottberg 82). In those circumstances, for the influence and power of any other group to be enhanced, there was a need for a collaboration with Afro-Cubans. Nevertheless, Moore, quoting Carlos Franqui's 1976 work Diario de la Revolución, argues that racial disharmony had existed in Cuba for a long time and suggested that "the contrasting disharmony is present

\footnotetext{
${ }^{14}$ For an explanation of the beginning of the revalorisation of Blacks and their culture and writers who took part in this process, see Miguel Arnedo-Gómez's Writing Rumba, pp.1-3.

${ }^{15}$ As explained earlier in Chapter 2, in relation to the historical background, the US was ready to invoke a military intervention in Cuban internal affairs any time they observed socio-political unrest.
} 
in all aspects of existence, but masked by the hypocritical saying, 'no problem!' But yet, there are very serious and deep problems. What needs to be done is to expose them fearlessly" (Moore, “Castro” 8).

In Chapter 2, I revealed the kind of segregationist situations in which Blacks found themselves. It emphasised the dire nature of the relationship between Blacks, Whites and the ruling elites. As we may recall from this chapter, although Afro-Cubans were participants in the fight for an independent Cuba, the situation at the level of social reality was very different as Afro-Cubans continued to suffer discrimination. Their roles as agents of socio-political change during the critical process of Cuba's transition from Spanish colony in the 1890s to a nation-state in the 1910s was not recognised (Helg 2, 11). In other words, the reciprocity and equal opportunities they (Blacks) had fought for, and which were enshrined in the Cuban Constitution, were denied them. Given the closeness with which both races had collaborated in the Wars of Independence and the high expectations both groups had for better conditions of life after independence, as well as the wide abyss that had actually been created between Blacks and Whites after independence, there was an increasing demand for change from Blacks.

At the nascent stages of the Republic, there was not a clear determination on the issue of Blacks and what benefits they could derive from the independence of Cuba (Helg 142-43). This was mainly because the few members of the Black middle classes that had been assimilated into dominant white societal life did not necessarily see anything wrong with the discrimination that the Black majority was suffering (Helg 142-43). ${ }^{16}$ It was not surprising that as far back as 1890, one of the heroes of Black Independence, Juan Gualberto Gómez made a statement that downplayed any attempt to claim any special rights or privileges for

\footnotetext{
${ }^{16}$ For a detailed discussion on how the collusion between black elites and whites began, see Helg, Our Righful Share, pp.142-145.
} 
the Black population in particular. Rather, he sought the union of races by laying claim to equality in the interests of nationhood. He argues:

Quiero borrar la mayor suma de diferencias que existen entre los negros y los blancos de Cuba; y esto lo quiero no sólo en beneficio del negro, sino también del blanco, porque mientras más duren esas diferencias, más difícil será al uno como al otro grupo étnico revestir los caracteres esenciales que necesitan las masas que quieran constituir pueblo, y más lejano está por consiguiente el día en que blancos y negros puedan tener la seguridad de constituir una nacionalidad. (Gómez 3)

His statement recognised the existence of differences between Whites and Blacks, which he intended to eliminate, but he did not identify these differences nor specifically address them as the foremost endeavour to undertake before the unity of both races and the nationhood of Cuba could be proclaimed.

This chapter argues that Nicolás Guillén's pre-revolutionary poetic work in the three collections cited emphasises a re-evaluation of the status of Blacks and questions the alleged achievement of racial equality in Cuba and the poems selected for this discussion recognise and re-interpret the issue of Blacks and Blackness in Cuba as an essential part of the Cuban nation and the Cuban condition. In the light of this, it is crucial to trace the trajectory of Guillén's views and representations of Blackness from the pre-Motivos de son era to the time of West Indies Ltd. (1934). Black elites, Whites and the ruling class asserted the existence of rights but did not apply them. In this chapter, the elitist or racist conception of Blackness held by the White and Black elites is contrasted with the representation Guillén puts forward in some of his poems from the collections of Motivos de son, Sóngoro cosongo, and others from West Indies Ltd. 
Guillén's work is seen as opening doors of opportunity for the recognition of Blacks' contribution to the nation of Cuba, which had gone unrecognised since the Wars of Independence. A significant corpus of literature has emphasised the continuous relevance of Nicolás Guillén's work to the understanding of Blacks and the status of Blacks in Cuba (Arnedo-Gómez 211, Duke 80, 101). Richard L. Jackson, for example, puts it thus: "[T]he role model Nicolás Guillén provided in the 1930s for literary Americanism was an effective one because his black poems struck several blows at once," and particularly in terms of the themes and the form of his work (27). As indicated by Hispanic scholar Edward Mullen, Guillén is relevant in debates and discussions about Blacks because of "his starkly realistic portraits of black urban life in Havana" in Motivos de son (221). Jackson also seems to endorse this view when he indicates that Guillén "rejected the superficialities" and lack of authenticity associated with the negrista poets' representation of Blackness. He rather "sought authenticity and a new American voice when he campaigned ... for fuller appreciation of the African roots of literary Americanism in Cuba" (27). In respect of form, Guillén creates a marriage between oral forms and traditional Spanish poetic styles and imports this hybrid form into Cuban poetry. His formal effects can also be observed in his use of high and low registers and the jitanjáforas. By so doing, he, in effect, makes "the Spanish ballad Mulatto" or he "Cubanizes it" (27). Jackson further argues that "Guillén wanted to recognize the human reality of the black Cuban, to strip him of his inferiority complex and to bring him to centre stage; and he wanted to fight prejudice and racial discrimination between blacks and whites and among blacks themselves" (27). Thus, Guillén's 1930s revolutionary poetry of Motivos de son emphasises his conceptions of Blackness and the need to discuss difficult issues concerning the Black man and woman at this time as a matter of urgency.

When Guillén represented Blacks in poetry, I will argue, it was to change the dominant ideology of Blacks as second-class citizens in the society of Cuba. For Mamadou 
Badiane, "the simple fact of representing blacks through poetry, at a time when some people thought they did not form part of the nation is an achievement that led to the re-positioning of national identity" (79). Blackness was an integral factor in Guillén's political and sociocultural sensibilities.

The poems selected for this discussion are based on Cuban life in which Guillén "was not emphasizing the black sector of Cuban society in order to make it a separate sector" (Ellis, "Guillén at Seventy" 89), but was rather drawing attention to the conditions in which they lived and to give visibility and authority to Blacks and their culture. The poet emphasises the need for all Cubans to work together as an integrated entity. According to Keith Ellis, “Guillén's pre-occupation in Motivos de son and in Sóngoro cosongo was rather with the whole Cuban society, with having Cuba identify itself correctly and, within this context, with having the African contribution to Cuban culture rightfully acknowledged" (Ellis 89). The three crucial points that I extrapolate from this quotation, which I use as points of departures of the discussion of Guillén's position on Blacks and Blackness are the need for Cuba frirstly, to correctly identify its problems, secondly to recognise its component parts, and finally to acknowledge appropriately the African contribution to Cuban culture and society. This will be shown by my analyses of Guillén's poetry.

For Cuba to identify its problems correctly, I will argue, Guillén steps into retrospection to evaluate Cuban historical antecedents and then present in clear terms the discrimination and the abuse Blacks suffered under the Republic. ${ }^{17}$ Through his essays and the poems in Motivos de son, Sóngoro cosongo and West Indies Ltd., Guillén incorporates and represents Blacks and the issue of Blackness in his work. In the next section, I discuss Guillén's views and experience of Blackness and racial discrimination in some of his preMotivos de son poems and essays.

\footnotetext{
${ }^{17}$ As I will later argue Armah does when he adopts the sankofa principle and reaches into the past to tell the story of the present.
} 


\subsection{Guillén's Experience of Discrimination and His Entry into the Debate on Blackness}

How does Guillén enter the debate regarding Blackness and its representation in the literary works of Cuba in the 1920s and 1930s? Let us bear in mind that the poet's knowledge of the dysfunctional and weak Republican practice of racial equality became more acute when he, as a growing adult, was discriminated against because of his colour.

Guillén's pre-Motivos de son essays from the Diario de la Marina newspaper, ${ }^{18}$ a conservative Havana daily dedicated to the daily happenings in Cuba, openly discussed the issue of segregation and discrimination against Blacks. These essays "El camino de Harlem", "La conquista del blanco" and "El blanco: he ahí el problema" appeared between April and June 1929, around the same time as he was writing Motivos de son. Many critics have described the manner in which he presented these issues as not forceful enough, to the extent that some have described him as being conciliatory in his approach to Whites, rather than revolutionary. His moderate approach is attributed to his upbringing, as an educated mulatto from a respectable middle-class family (Arnedo-Gomez 55). He is reproached by this critic for not broaching the issue of the slave trade and its effects on Blacks at all, and for celebrating a white figure of independence, Carlos Manuel de Céspedes, rather than General Antonio Maceo, a Black hero of independence. A careful study of these essays reveals that even though his approach was not "radical" in comparison with other Black writers like Ángel Pinto, Guillén in fact, makes a more assertive statement than previously thought with his three essays. That is, he argues strongly that there is an urgent need to address discrimination against Blacks in 1920s and 1930s Cuba and attributes responsibility for the current situation of discrimination.

\footnotetext{
${ }^{18}$ This newspaper, comprising between 20-30 pages, had a special column for Sundays, called "Ideales de una Raza" edited by the Afro-Cuban activist, writer and architect Gustavo Urrutia. This column was dedicated to issues of interest to and concerning Blacks. Guillén started contributing to this column in 1928.
} 
In "El camino de Harlem," first published in Diario de la Marina on April 21 1929, Guillén quotes Lino Dou, one of the leading black scholars of the 1920s who emphasised the important sacrifices that the Black fathers of the Cuban nation made to resolve "el gran problema de las relaciones entre los blancos y negros en Cuba, y a su resolución aplicamos todas las fuerzas de nuestro espíritu" (Guillén, "Camino" 3). Guillén lauds him, acknowledges the vital contributions that these people made, and expresses the need for young Black intellectuals of the present to continue fighting in order to make Cuba a better place for all, one where there is racial equality. There is also a clear acknowledgement here of the fact that the fathers of the nation literally fought in the trenches to build the nation to that point. The present generation of Black intellectuals must also take up arms and continue the struggle. The reference to "trincheras" here implies a call to arms, an appeal to hard work and the fact that the fight to eliminate discrimination is not going to be an easy or quick one.

In the opening paragraphs of this same essay, Guillén interrogates the issue of discrimination against Black Cubans who, in theory, were covered under the provisions of equality in the Constitution of Cuba. He probes this issue because of his concern about segregation and because many people pay lip service to this issue of equality but the reality, which he seeks to make visible, is one of active discrimination against Blacks. He begins by revealing the problems and suggesting ways of addressing these challenges.

He continues the essay indicating that, even though he is sceptical that this challenge of discrimination might never be resolved, he finally arrives at the conviction that this problem "debe y tiene que resolverse" ("Camino" 4). He argues that "el hecho de que aún subsista, desgraciadamente, en un medio político de tan fraterno origen como el nuestro, no debe inspirar desaliento $\mathrm{y}$, menos aún, hacernos desertar de una lucha que es realmente patriótica" (4). He also however cautions all Cubans against exaggerated optimism that would blind them to the "durísimas realidades ambientes" and suggests that the only way 
forward is for Cubans to know where they are in their history as a nation- "hay que colocarse, pues, en el verdadero lugar en que nos han colocado; observar si ése es el que nos corresponde, por nuestra historia y por nuestro progreso"- and fight to "avanzar seguramente hacia el plano" (4). His use of military language here, and "desertar" and "trincheras" in the earlier paragraph, also emphasises the urgency of the call to continue the fight for racial equality.

Guillén also cautions against the hypocrisy of both Blacks and Whites indicating that even though Blacks and Whites call each other brothers and friends, they live separately from each other in parks, dance halls and barbering shops, creating Black only and White only spaces. He is, however, clear on one thing; that is, discrimination extends to every coloured person and whether one is closer to the white end of the skin colour spectrum or not does not matter. He cites his own experience as an example: when he applied for a job after the death of his father, at a Railway Corporation where the latter had influence, was well known and respected, Guillén was discriminated against because of his colour. Initially, he had thought naïvely that he was "un mulato bastante claro "y de pelo"" (4) and coupled with his middleclass status and good education-“casi bachiller, ya mecanógrafo y con más ortografía y conocimiento de redacción que muchos"- he had a better chance at getting a job (4). However, it took someone who understood the society very well, whom Guillén refers to ironically as an "alma caritativa," to explain to him that "mientras no cambiara de color ... sería imposible teclear en las más humilde de las 'Underwood' de ... Cuba" (4). Thus, Guillén was well aware of the discriminatory nature of Cuban society.

However, his observation was not just based on his personal experiences. In a 1972 interview with Dennis Sardinha, Guillén declared,

From my childhood, then, I saw the spectacle of discrimination against Negroes because of the colour of their skin, and against a few whites too because of their 
social extraction. This turned me into a rebel against a society like that, and from that rebellion sprang my non-conformity not only as regards racial prejudice, but also against all others; that can be seen in my poetry. (Sardinha 69-70)

This quotation reflects Guillén's perspective that any form of discrimination against Blacks and any other group in Cuba should be fought, and he, as a poet, uses his medium to address these issues.

Guillén concludes this essay indicating his reasons for revealing such problems: "[C]uando las digo no me anima más deseo que el de sacar a la luz muchos de nuestros males, desempolvarlos y exponerlos al sol de todos, blancos y negros" (4). It is crucial to say these things also because most people are not ready to deal with the root problem: "[E]stamos preocupándonos exclusivamente de las formas, y tenemos verdadero terror en llegar al fondo del problema, que es grave" (6). His essay is his way of tackling the problem from the roots so that Cuba would not travel down the disastrous Road to Harlem, ${ }^{19}$ leading to the creation of ghettos exclusively reserved for Blacks. Thus, he is very much against creating a society divided by race. This call to reject the Road to Harlem lays emphasis on Guillén's objective from the outset: that both blacks and whites should take the responsibility upon themselves of constructing a common Cuban society in which both can freely claim a sense of belonging and fully partake of their rights. In other words, each race must be recognised equally, their contribution to the building of the nation acknowledged, and all work together to eliminate racial discrimination.

In "La conquista del blanco", published a little over a month later, Guillén speaks to Blacks directly and includes himself in this address (often using the pronoun "nosotros"). In this essay, Guillén refutes the argument of some white intellectuals that discrimination is cultural and that once Blacks are able to attain "un alto desarrollo del nivel mental"- -have

\footnotetext{
${ }^{19}$ Here, Guillén compares the situation of Harlem in the USA, where the problem of segregation of Blacks was so rampant and intense, to that of Cuba.
} 
become learned and educated - Whites will respect them. He explains that it is important that Blacks examine the truth or otherwise of this statement in the light of their own experience and find a way of taking advantage of any opportunities that might be presented to them.

He describes the present situation of Blacks and Whites and gives a scenario of a Cuban of "cultura media," whom he characterises as someone who is neither "analfabeto" nor positioned at "las altas cumbres del pensamiento en una dirección cualquiera" (that is, is neither illiterate nor included in the category of "mulatez intellectual"). Guillén puts forward the argument that, although a middle-class white Cuban as described above does not have to study to reach higher heights in order to get jobs, or struggle for them, the same does not apply to a black person of the same status.

He outlines in detail the ways in which this discrimination works. Guillén goes on to ask Blacks to do away with what he calls their "social sickness": timidity—which is reflected in their unwillingness to appear in public spaces together with Whites. In Guillén's opinion, Whites are not used to seeing Blacks in public and other important places and so they have therefore not developed the habit of working or associating with them as equals. In this, he attributes some responsibility to Blacks, maintaining that they must reject what he calls their "vanidad" of not wanting to mingle with Whites and occupy positions for which they qualify. He cautions that Blacks should not fight with Whites, but rather should make friends with them and make themselves visible, implicitly demanding their rights by appearing with them together in "sitios públicos," and making Whites aware that "somos de verdad sus hermanos." Thus, he asserts that part of the solution lies, in part, with Blacks themselves: "[L]a resolución de nuestros problemas, está, pues, en nosotros mismos" (8). That is, they (Blacks) must demonstrate to Whites that "nuestra piel oscura está cubriendo un hombre que se parece muchísima al que late detrás de su piel blanca" (8). 
Most critics have read Guillén's position in the quotations above as a reluctance to attribute the failures of the Republic in achieving the aim of racial equality for all in Cuba to the Whites and the Black elite. Consequently, Guillén has been described as occupying an ambivalent position: he does not condemn the White ruling class nor the Black elites but attributes the duty of emancipation of Blacks to Blacks who should fight for themselves. One critic suggests that "he was subtly transferring the responsibility for this cause onto his own generation of black Cubans and advocating a new direction that did not rely on the myth of racial equality to the same extent" (Arnedo-Gómez 40). However, what is clear is that Guillén is not blaming Blacks for their situation; he was rather seeking to make them aware of the need to take up the responsibility to demand (and fight for) what is "rightfully" theirs, as Helg would put it. He demonstrated to both Blacks and Whites that there were still problems regarding the status of Blacks in the Republic. Indeed, he was emphatic about it in the opening line of this essay: “¿[C]uáles son los problemas de la raza de color, hoy, en la República de Cuba?" There was the need therefore, for Blacks to demand a solution to these issues from the Republic and its systems and to play their part.

In the third essay, "El blanco: he ahí el problema," Guillén's tone is more confrontational, emphatic and to the point. He is sarcastic too in his expression in this essay when referring to race relations in Cuba: “[B]ajo el ala amorosa de una legislación prudente y liberal se abrazan enternecidos, derramando lágrimas de felicidad, el negro y el blanco ..." (10). He indicates that the problems of Cuban Blacks are not due to a lack of relevant provisions in the laws of the land to protect them. The Cuban Constitution, which Guillén calls "Carta fundamental" recognises "la igualdad de todos los Cubanos ante la ley" (10). However, in practice as shown earlier, they are not equal. For Guillén, denying Blacks their rights would be classified as "grave y conspira contra la cohesión y la vitalidad nacionales." 
Guillén's goal is to bring clarity to "estas oscuras cuestiones" so the public would be able to understand the issues as they are presented "sin incurrir en falsas generalizaciones" (10).

He argues that there is little point in reminding Blacks of the progress that the Black race has made so far, nor is there a reason to point out that Blacks are equipped to function in sectors such as intellectual work or the business world. Blacks are already aware of these issues and they appreciate them better than anyone else. Likewise, there is little point in telling Blacks time and again that the laws are made for both Blacks and Whites. The key problem is the lack of political will of Whites to acknowledge the legal rights of Blacks: “[L]a ley no le niega ningún derecho, pero que el blanco le reconoce muy pocos” (10). No matter how well-prepared Black professionals are, he argues, "los blancos los consideran negros antes que profesionales, adoptando una actitud de reserva $-\mathrm{y}$ de agresión a vecesfrente a la mayor o menor oscuridad de la pigmentación cutánea" (10). He concludes this essay by demanding action from Whites; that is, they must recognise Blacks as their equals. There should be equal opportunities for Blacks and, in these situations, there should be "idénticos derechos." If this is not done, there will be no progress in the quest to bring the two principal communities of Cuba together. Clearly, here, Guillén is placing the responsibility of creating an environment of mutual respect and racial equality squarely on the doorstep of Whites.

All three essays highlight Guillén's project of addressing the concerns that Blacks had had since the establishing of the Republican Constitution that contained relevant provisions for the equality of races in Cuba. Guillén also argues implicitly for making Blacks visible in Cuba, that is, putting Blacks (Black men, Black women and the Black working class) centre stage and in addition, encouraging and empowering them to recognise what they can do to help themselves. Thus, he foreshadows the themes of his later poetic works in all three of his submissions to the newspaper. 
In another of his pre-Motivos de son works of 1929, this time a poem entitled "Pequeña oda a un negro boxeador cubano," which also appeared in the Diario de la Marina around the same time as the essays above, Guillén exposes the contradictory world of Cuba. He indicates that in this world, the boxer, a black Cuban, must entertain his white audience who will either approve of his bravery and courage, or risk his career. The Black man in the ring must confront both this other boxer, putting his life at risk, and the world at the same time. In this poem, we see Guillén urging the black boxer to fight on, both in the ring and outside of it, in order to break every barrier to his acceptance in society and to hold on to Black pride. The poem ends on a note of defiance, disavowing the myth of racial equality and making an overt appeal to the upholding of pride in Blackness urging the boxer to "lucirse negro mientras aplaude el bulevar, / y frente a la envidia de los blancos, / hablar en negro de verdad".

To conclude, in his essays, Guillén argues that discrimination exists, that it is racial not cultural and, there is a need to make these concerns public or visible-people should be made aware of these issues. He emphasises that Blacks have a role to play - that they should be visible, proud and assertive in all that they do. Finally, he places the responsibility for making equality work in the nation of Cuba at the feet of Whites. If Cuba does not address these issues, he argues, the country will end up following the negative example of the USA. He continues this project of creating a platform through his work for a socio-politico-cultural visibility and self-discovery of Blacks in Motivos de son. With this act of bringing issues concerning the position and relevance of Blacks to the fore in his poetry, Guillén inaugurates a new era in the literary development of Cuba in the 1930s. For Guillén, holding on to and asserting Black pride is the way that Blacks will gain recognition in the hostile climate of the time. However, as will be seen in the next section, Guillén's Black poetry in Motivos de son was criticised, just as any work that goes against the dominant cultural prejudices will be. 
This was particularly so because his work contested the official rhetoric that Blacks were already equals in Cuban society (Domínguez et al. 201).

Some critics (Fernando Robaina [128], Arnedo-Gómez, [56]) adduce the idea that Guillén, being a middle-class Cuban, may not have been able to represent faithfully the Blacks that he wrote about because he did not belong to the lower-class Blacks circles, but the writer thinks otherwise. In the earlier quoted interview with Sardinha, Guillén declared that he became a rebel against Cuban society because of "the spectacle of discrimination" that he observed against Blacks and against "a few Whites too because of their social extraction" (Sardinha 69-70). This was proof that the poet was not observing from an ivory tower, nor was he oblivious to the extent of discrimination since, as indicated earlier, he experienced it himself.

As already discussed in relation to his essays, Guillén inaugurated a new era in his literary development in the 1930s by addressing the issues of Blacks openly, and suggesting what both Blacks and Whites could do to promote a truly harmonious and racially equal society in the nation of Cuba. He continues this project in Motivos de son where he represents the lives and situations of Blacks in a realistic manner, stressing the importance of Black pride. I argue that in the focus of these poems, Guillén emphasises the need for Blacks, as a matter of urgency, to identify and occupy their space in society and, more importantly, the crucial need he articulates in his essays for Whites to recognise the rights of Blacks as enshrined in the Cuban constitution.

\subsection{Motivos de son and Guillén's Conception of Blackness}

This section discusses the poems in the collection of Motivos de son, their critical reception and Guillén's conception of Blackness in three of these poems. Before analysing these 
poems, it is important to first briefly examine Guillén's formative years, initial influences and the kind of poetry he wrote prior to this collection.

Nicolás Guillén was born in Camagüey into a middle-class mulatto family. When growing up, he spent time with his father at the latter's printing press. He used every opportunity to read books he found in his father's library and later discussed the issues from the readings with his father (Guillén, "Nací" 386-87). His paternal grandfather-a carpenter who also dedicated time to his other passion, writing poems - also motivated him. Even though Nicolás did not go to the best of schools due to the family's economic circumstances, he ended up with a good education, mainly due to his time working in the printing press. These two together (his grandfather and his association with his father) served as his main literary stimuli. It came as no surprise when in 1916, at the age of fourteen, he wrote his first poem (Madrigal 11). In this untitled poem, Guillén describes the landscape of Cuba in a style reminiscent of romantic poetry. His later poems of this era depicted varied themes like the French revolution, love and friendship, as well as poems on the seasons and many other topics. $^{20}$

Guillén completed his High School qualification in 1919 and was already making inroads into the literary scene of the town. Within a short while, he was recognised among the literary circles of Camagüey. More importantly, he had his first verses published in the Camagüey Gráfico magazine. In this collection of poems, Guillén showed his aesthetic preference for modernismo, with the poems not showing any preoccupation with social injustice (Madrigal 12).

In 1920, Guillén decided to go to Havana for the first time to study law. However, he did not live there for long as his savings were meagre and he had no additional income to support himself. He did however meet Lino Dou, a close associate of his father, who

\footnotetext{
${ }^{20}$ For more on Guillén's early poems and the progression from them to those of Motivos de son, see Ellis's Cuba's Nicolás Guillén: Poetry and Ideology (51-63).
} 
encouraged him to continue his literary pursuits (Cairo Ballester 78). This he did once he returned to Camagüey in 1922, founding the Lis newspaper, which only lasted for about six months, forcing him to later take up a position as a columnist with El Camgüeyano (Madrigal 12). From this time, until 1925 when he returned to Havana, Guillén was more interested in organising workshops and giving presentations than writing poetry. Nonetheless, in 1927, he published some of his poetry in the Orto newspaper, one of the leading literary reviews in his native town.

He was particularly attracted to the works of Nicaraguan modernist, Rubén Darío, whose influence was perceptible in most of the poems of the collection Cerebro y corazón which he had written earlier in 1922 (Madrigal 14). The period of time spent in Havana was formative in his life as he met many people and became aware of the challenging conditions Black Cubans were living in, and these circumstances were reflected in his later poems of Motivos de son, published in 1930.

\subsubsection{The poems of Motivos de son}

The first versions of Motivos de son appeared as a result of Guillén's contribution to the Diario de la Marina, the same paper that published his essays in a Sunday column called "Ideales de una Raza" in 1929. This section was dedicated to writings that throw light on the difficulties Black Cubans were confronted with (Sardinha 10). Historical evidence shows that the readership of the paper extended to all Havana and beyond, as it had a high circulation. The poems by Guillén that appeared in this column were later compiled into a book called Motivos de son and published in 1930. Its themes ranged from the issue of Blacks' search for food, their work, their appearance, their economic wellbeing, clothing, to relationships. 
This book is a collection of eight poems that use a form adopted from the musical genre called the son. ${ }^{21}$ The first version of the collection of these poems included "Negro bembón”, "Mi chiquita”, “Búcate plata”, "Sigue...”, “Ayer me dijeron negro”, “Tú no sabe inglé", "Si tú supiera...", and "Mulata". He then added three more poems to this collection: "Curujey", "Me bendo caro" and "Hay que tené boluntá" but he finally discarded three of these poems ("Ayer me dijeron negro," "Curujey" and Me bendo caro"). ${ }^{22}$ Thus the definitive collection comprised "Negro bembón", "Mi chiquita", "Búcate plata”, "Sigue...”, "Tú no sabe inglé", "Si tú supiera...", "Hay que tené boluntá" and "Mulata" (Ellis, "Cuba's" 65). All the poems in Motivos de son deal with the lives of lower-class Blacks of Havana, as Guillén observed them.

This collection of poetry captures the vocabulary and manner of expression of Blacks. It adopts the voice of Black lower-class characters of both sexes and uses a type of Spanish that has been orthographically modified to imitate the speech patterns of the lower classes of this population. The speech acts of people found in the poor neighbourhoods of Havana are unique and Guillén captures this in his poetry in order to emphasise his commitment to giving to this section of Cuban society their own voice that had been ignored for a long time.

The setting, focus and the language of the collection give the reader the impression that Guillén conceives of these poems as solely black poetry and the poems are restricted exclusively to a focus on the black subculture he saw in the poor neighbourhoods of Havana. The poet represents Blacks as not being at all equal to the Whites of Cuba, depicting them as living in slums and in abject poverty_conditions which most writers and poets of 1920 s and 1930s Cuba would not have written about in their works. Although this representation of

\footnotetext{
${ }^{21}$ The son has been described as "a passionate dance born of the Negro-white encounter under Caribbean skies" (Augier and Bernstein 32), a "ritualistic dance" (Echevarría 306), and as "the central musical type in contemporary Cuban popular music" (Robbins 182). See James Robbins' “The Cuban 'Son' as Form, Genre, and Symbol," for more on the meaning and symbolism of the Cuban son.

${ }^{22}$ These poems are not considered in this thesis because they do not form part of the definitive collection of Motivos de son.
} 
Blacks and their condition in Motivos de son sits at odds with the modernism shown in his earlier poems, it demonstrates the substantial knowledge he had acquired of the socio-cultural conditions around him.

The poet himself suggested at the completion of the collection of Motivos de son that the poems' central purpose was to bring the issues of the Black lower-class population to the attention of society (White and Black elite). In doing so, he was undertaking the role of an engaged poet by representing the injustices that surround him. But also, he sought to accurately represent Black culture in a poetically compelling manner. He states that the poems "hicieron volver los ojos de la crítica oficial hacia un fenómeno no considerado hasta entonces importante, o mejor dicho, existente; el papel del negro en la cultura nacional, de que eran prueba aquellos poemas cuyo ritmo indicaba la posibilidad de amulatar el romance español, esto es, cubanizarlo, volviéndolo a su ser pristino" (Morejón, “Interview” 42).

Guillén exposed the day-to-day conditions of the lives of Blacks to show the suffering that this sector of the Cuban population endured. The reasons for this exposure are twofold: to appeal to the conscience of Whites and the elites to change their attitudes and, secondly, to raise consciousness among those middle-class Blacks who continued to live oblivious to the fact that the national rhetoric of racial equality was false. The echoing of these themes in his poetry is a reminder of and an elucidation of the problems of Cuba that he refers to in his essays.

\subsubsection{The critical reception of Motivos de son}

When the first copy of the collection of Motivos de son was sent to the White Cuban poet and essayist Emilio Ballagas, he responded favourably. He wrote to Guillén: "[Y]ou have hit the nail on the head because you heed your 'interior voice,' which is not exactly that individual thing that the I-ists [yoistas] believe in, but the collective voice, the popular soul, the 
ancestor's cry in a strong and comprehensive manner ... no one else has gotten to the center of the popular circle with such accuracy" (cited in Ballester 80). This critic celebrated the approach Guillén took towards his Black compatriots, identifying the realities of Black Cuban life. Ballagas perceived the poems as a response to the call Guillén felt from his soul to represent the collective voice of Blacks and to paint a picture of their reality, lives, hopes and dreams. This is a call for a complete representation of Blackness, heeding the appeal by the Cuban black sculptor Teodoro Ramos Blanco in the late 1920s, "to create a genuine national culture in which blackness was not reduced to a merely decorative element in an exotic environment" (cited in De la Fuente, "Nation" 185).

Clement White maintains that Guillén's Motivos de son was written to describe in as much objective detail as possible the socio-cultural conditions of Blacks in Cuba, not "as a judge" but rather to engage in an honest representation of their reality (37). In these poems, Guillén recreates "the ambience of human despair, misery and hopelessness, and in so doing emphasises the level of urgency of the situation" of Blacks (37). However, the reception of the poems of Motivos de son amongst Blacks was not entirely positive. White, referring to an interview Guillén granted to Nancy Morejón, states that "many Blacks in the 1930s saw in his apocopated, onomatopoeic verses ... a sordid reminder of their so-called inherent inferiority" (quoted in White 31). Arnedo-Gómez also alludes to the fact that some black middle-class groups condemned the poems (86). Others, like scholar and critic Lemuel Johnson, refer negatively to the collection as examples of "the broken dialect, disfraces negros of the bozal" (cited in White 33).

However, Josaphat B. Kubayanda argues that Guillén's Motivos de son "was the first successful development in Cuba of a vital and original aesthetic based upon the black and African elements" (1). For Sardinha, the impact of these poems was "stupendous". Here for the first time was black folklore turned into poetry and it "was tremendous" $(11,13)$. Ellis 
maintains that, for some, using the son as the basis of the poems "constituted too extreme an aesthetic initiative and too disturbing a social manifestation" ("Cuba's" 64). However, he agrees that the poems made a positive impression on many people. He argues that "it was as if Guillén had touched on something active in the consciousness of a few but which was submerged in the unconscious of most Cubans" (Ellis 64). Furthermore, Ellis also suggests that the poems "offer a rich concentration of images and devices that work to open a window into the life of the humble Black sector of the Cuban population" (66).

Morejón describes the poems in the context of the poet's own experience when he lived in Havana, suggesting that the collection is the point of departure in Guillén's questioning and interpretation of what was going on around him when he lived in the city. Furthermore, she argues that they also constituted a re-discovery of his own identity as Black. She argues that in these poems Guillén "inaugura un proceso de conocimiento de su condición humana" (Morejón, "Prólogo" 10). As can be seen from the opinions above, from the time of their publication, the reactions to the poems were certainly not uniform, and this mixed reception has continued even to the present day-as evident in the various critical interpretations of them.

\subsubsection{Guillén's conception of Blackness in three poems from Motivos de son}

In this section, I will briefly summarise the eight poems contained in Motivos de son, and will go on to discuss the three poems that particularly present the issue of Blackness: "Negro bembón, "Mulata,” and “Tú no sabe inglé.” In doing so, I elucidate Guillén’s understanding of the most pressing issues relating to Blacks. As a poet and an engaged writer, he highlights these issues and explores how they affect Blacks in the future nation of Cuba, with the intention of shedding light on them, in order to resolve them - a project he had already started in his essays. 
"Negro bembón," the first poem of the collection, represents a day-to-day situation of Black lower-class street life. The character described in the poem feels unhappy because he is identified by his facial features which he cannot change. In "Mi chiquita", the Black suitor articulates his pride in the capacity of his partner to take care of the home and her other attributes, above all her Blackness. In "Búcate plata," the female speaker urges her male partner to go out and look for money for the upkeep of the home. In "Sigue..." a Black woman is maligned by a jilted suitor and in "Tú no sabe inglé," a Black man bears the brunt of teasing from a Black woman for his preference for an American woman, despite his inability to communicate in English. "Si tú supiera..." portrays the unsuccessful attempt of a suitor to deride a former lover because she left their relationship. "Hay que tené boluntá" explores a Black woman's poverty, and the need for drive and resilience to overcome economic adversity. Finally, "Mulata" presents the issue of racial pride and the negative and destructive ideology of whitening in an exchange between a mulatto woman and a Black man. Some of these poems are focused particularly on the lives of Black women and I will examine these in the next chapter. Here, I analyse the poems that focus specifically on aspects of Blackness and its impact on Black lives.

\section{"Negro bembón"}

The speaker of this poem could be an older, wiser, lower-class Black Cuban addressing the young Black man who is not happy with his physiognomic traits: he has thick lips, common among Afro-Cubans, and this makes him unhappy, even though on another level, he has everything he needs. ${ }^{23}$ This poem starts on a reflexive note, presumably reflecting on how

\footnotetext{
${ }^{23}$ Monica Kaup takes it for granted in "Our America" That is Not One: Transnational Black Atlantic Disclosures in Nicolás Guillén and Langston Hughes" that the speaker of the poem is likely to be the boy's female lover (95).
} 
often the Black boy gets angry when people call him "negro bembón." ${ }^{24}$ The speaker asserts that the Black boy should be content with his physical traits — his thick lips-which, to the speaker, are not just thick but are "saintly"-a harmonious unification of the physical and the spiritual.

$$
\begin{aligned}
& \text { ¿Po qué te pone tan brabo, } \\
& \text { cuando te dicen negro bembón, } \\
& \text { si tiene la boca santa, } \\
& \text { negro bembón? }
\end{aligned}
$$

The speaker (who could be read as reflecting the view of the poet) argues that the "negro bembón" has no grounds for complaint—-his thick lips are beautiful and, above all, they are what he has; he cannot exchange his mouth for another one. He is urged to accept the racial features that are part of his physique.

The next stanza stresses the fact that his looks are natural but that above all, he is in a privileged position because he is taken care of financially:

Bembón así como ere

tiene de tó;

Caridá te mantiene,

te lo dá tó.

The final two lines are ambiguous and have been explained by critics in two ways. Caridá either alludes to the name of a woman (Charity), or to charity, the concept. In the first sense, his partner Charity provides for all his needs; in the second sense, he survives on donations from charitable organisations and hence he is also taken care of.

In the next stanza, the poet identifies and emphasises the man's ingratitude despite the opportunities for self-acceptance and development he has and stresses that he needs to count himself lucky:

\footnotetext{
${ }^{24}$ Langston Hughes and Ben Frederic Carruthers translate "negro bembón" as "thick lipped cullud boy" in Cuba libre (1948), p 5.
} 
Te queja todabía,

negro bembón;

sin pega y con harina,

negro bembón,

majagua de drí blanco,

negro bembón;

sapato de dó tono,

negro bembón.

Here, even though he does not work (sin pega), he eats well (con harina) and wears a white suit and two-toned shoes. Through the constant repetition of the phrase "negro bembón", the poem acquires a critical tone: the speaker appears disapproving of the attitude of the Black boy and, by extension, that of many Blacks towards who they are and their appearance. The very phrase "negro bembón" in Cuba at the time according to Isidore Smart, "incorporates a whole world of racism, and black self-contempt — an essential feature of the black man's condition" (359), and is one which needed to be eradicated through self-acceptance and pride. Smart opines that "the intent of the poet is to instil a new feeling of defiant acceptance, perhaps even pride in the poor black urban dweller, traditionally ashamed of his racial characteristics" (359). Kaup affirms that "Negro bembón" is "an intelligible message of a simple affirmation of blackness: 'Be yourself" (95). I argue that this is also a call directed at the Black man to make him aware of the "wrong" he is doing by living off his partner (or charity) and not looking for work to support himself. ${ }^{25}$ In laying bare the shortcomings of the lower-class Blacks of the poor neighbourhoods of Havana, I argue that Guillén decries the general situation, rather than the behaviour of individual Blacks in these conditions. In this poem therefore, there is a call for the man to accept his physical Black reality, to take pride in

\footnotetext{
${ }^{25}$ Arnedo-Gómez, referring to Pasmanick's Décima and Rumba argues that the imagery of a lazy black boy who lives off his partner is a recurring classic motif in rumba lyrics (Uniting Blacks in a Raceless Nation, 82).
} 
himself and to adopt a positive attitude towards these realities, as Guillén stressed in his three essays.

\section{"Mulata"}

This poem is written from a Black masculine first-person singular narrative perspective and is presented as a monologue addressed to a woman - a "mulata" —of mixed race. As will be established in my analysis, this poem engages with the ideology of whitening, its impact on Blacks and, again, the importance of reclaiming and valuing one's blackness.

In this monologue, the Black speaker of the poem is implacable in his condemnation of the mulata who, he says, goes around criticising him for his African features and, it seems, boasting of her own less African features as if they were superior. The narrator explains to the mulata that in fact both of them have similar physical features - there is only a difference of degree — and that her praising and self-flattery are false:

Ya yo me enteré, mulata, mulata, ya sé que dise que yo tengo la narise como nudo de cobbata.

Y fijate bien que tú no ere tan adelantá, poqque tu boca é bien grande, y tu pasa, colorá.

In the interaction between the Black male speaker and the unseen, absent and "mute" female persona, Guillén emphasises the issue of racism in Cuban society, even between Blacks. He uses the speech of the mulata, reported through the Black man, to highlight the racist slurs 
hurled daily at Black people in Cuban society at the time. The poem presents this interaction at the level of two individuals, but can also be read more generally as extending to the broader society. The mulata here is reported as insinuating that he has a big nose and the male speaker for his part points out the mulata's large mouth and nappy hair. He further complains that all the mulata's showing off of her body, her mouth and her eyes do not amount to anything that convinces him to change his mind about the negra that he has, thus showing the conflict between people in different points of the colour spectrum.

White argues that for Guillén "such a conflict between two people of the same heritage makes little sense. It does not alleviate the poverty which oppression brings nor resolve inner conflicts and moral compromises directly resulting from economic pressure" (39). He goes on to state that Guillén "affirms immediately that in spite of the in-fighting and perpetual sparring" as depicted in this poem, "no real appreciable difference exists between el negro and el mulato" (37) and, in the wider society, they are judged equally harshly, as Guillén observes in his essays. Guillén makes this affirmation of sameness between the two personae of the poem clear in lines 5-8 of the poem, emphasising their commonalities. White reads this poem as a critique of "the tendency of some Blacks to gravitate toward companions of a lighter complexion" (White 38), while Arnedo-Gómez opines that the speaker puts forward a "direct affirmation of the aesthetic value of black physiognomy" (69). He further argues that the speaker's declaration of pride in his Black woman (over the mulata) is "a gesture that reaffirms the value of black physiognomy and undermines the idea of marrying a whiter person in order to advance socially" (70). In my opinion, it also implicitly condemns someone lording it over another person because of his or her whiter appearance. In this case, the mulata sees herself as superior because she is aligned with the whiter end of the skin colour spectrum, but the Black man rejects that line of argument. 
It is evident from the poem that the male speaker is not happy about what the mulata says of his physical appearance, that he had a nose similar to a "nudo de cobbata." He feels insulted but responds by articulating his pride as a Black man. It is clear from the accusations that the mulata has assimilated the dominant (White) ideas about physical traits perceived as "black" and therefore negative, and is mocking the Black man as a White might do. The mulata's provocative insults energise the Black speaker to reject the mulata and the dominant ideology of whitening she represents. Rejecting the white aesthetics of the time, he affirms his preference for his negra.

I argue that the poem captures in miniature what was happening at the level of social reality and affords the reader an example of the tragic impact of racism on those supposed to be victims of this phenomenon, as they turn it on themselves-Black-on-Black racism. The mulata acts out racist attitudes as they affect the daily lives of Black people. Her insults, thus, provoke at once an expression of racial pride in the Black man in response and lead him to denounce implicitly the ideology of whitening she represents.

\section{"Tú no sabe inglé"}

"Tú no sabe inglé," like "Mulata," is a dramatic monologue in which this time a Black woman speaks to a Black man named Bito Manué (Victor Manuel), her implied interlocutor. The main focus of the poem seems to be the Black woman's disgust at the choices that the male character makes in terms of his status and relationships, resulting in a preference for "la mericana" over her. ${ }^{26}$ It also mocks the Black man's inability to speak English properly, a fact which will make his relationship with "la mericana" impossible.

\footnotetext{
${ }^{26}$ Even though it is not specified in the poem whether "la mericana" is white or black, she is certainly not Cuban. I assume that she is a white American because, as outlined in the historical background, the ideology of blanqueamiento, which encouraged migration to Cuba, favoured White Americans and Spanish citizens over Blacks.
} 
This poem starts on a very sarcastic note and makes a strong argument about Bito Manué's uselessness, largely due to his inability to speak English. The Black female mocks the man for his decision to advance himself socially by learning to speak English, which presumably he boasted of, and his apparent failure at this enterprise:

Con tanto inglé que tú sabía,

Bito Manué,

con tanto inglé, no sabe ahora

desí ye.

His mastery of English does not go beyond "trai guan y guan tu tri" ("strike one and one, two, three"-terms from baseball) and therefore puts him at the mercy of "la mericana" who is seeking him out and, in the female narrator's eyes, he must flee from this predatory woman.

La mericana te buca,

y tú le tiene que huí:

tu inglé era de etrái guan,

de etrái guan y guan tu tri.

The poem suggests a failed and ludicrous attempt at appropriation of the whitening ideology resulting in disgrace for the Black man. Through the female speaker of the poem, we get a sense of the prevalence of the issue of status linked to social and racial whitening in Cuban society and a condemnation of it. We also appreciate how furious she is and, by extension, the poet's attitude towards this issue.

The second stanza simply states that "la mericana" is looking for the man and that he should flee because his English does not reach a level that would allow him to communicate with her. In the last stanza, the female speaker urges him not to fall in love again. With the five repetitions of "no sabe ingle," one arrives at the conclusion that the poet is addressing two issues: the ideology of whitening and the consequent ridiculous desire of some Black men to marry white (foreign) women for social advancement when clearly they lack the skills to communicate meaningfully with them. 
In this poem, the Black man pursues a relationship with an American woman, instead of an Afro-Cuban woman, presumably to take advantage of whatever economic benefit that comes with social mobility. Thus, he is torn between being himself-a Black man who accepts his compatriot Black woman and loves her the way she is (as in "La mulata")—or pretending to speak English in order to achieve social mobility through being with a foreigner. The poem highlights the importance of this issue of Blacks' lack of selfacceptance, and the lack of authenticity among certain sectors of the Cuban society at the time. White calls the poem "a forceful note chastising a race falsely admitting outside values and not promoting its own" (White 65).

"Tú no sabe inglé" is a note of rebuke to some Blacks from a Black perspective but is also a critique of the influence and impact of the phenomenon that the White elites in Cuba in general had created; that is, the desire to make the nation "white" through a process of blanqueamiento as discussed in Chapter 2. The Black woman's attitude in this poem firstly condemns the ideology of whitening promoted by White Cubans with a view to diluting and gradually eliminating the Black element in Cuba, and also chastises the Black man for absorbing this belief that ascribes inferiority (both racial and linguistic) to Blacks as mentioned in Chapter 2.

In these poems Guillén highlights such features as "boca santa," "la narise como nudo de cobbata," "boca grande," and "tan negra" as some of the distinctive physical features of this community in order to celebrate their Blackness. In emphasising these characteristics, Guillén seeks to create an awareness in Blacks about the need to recognise their uniqueness and to be proud of it. ${ }^{27}$ Guillén's depiction is also important since the next step after Blacks' identification of their physical uniqueness is for those in the poor neighbourhoods of Havana

\footnotetext{
27 This issue will also be discussed under the representation of women and in the poem "Mi chiquita and "Mulata."
} 
to fight for social recognition and lay claim to their unique identity and role in the nation of Cuba.

These three poems of Motivos de son reveal in poetic form Guillén's deep awareness of issues relating to Blacks. In Motivos de son, then, he continues the crusade he started in his essays to make the situation of Blacks in the nation of Cuba visible, and he asserts the need for Blacks to be proud of who they are and to not subscribe to anti-Black prejudices and selfhatred. In Guillén's following collection of poems, Sóngoro cosongo, we see the poet move from focussing exclusively on Black Cubans towards concentrating on Blackness in relation to the nation of Cuba as a whole, but even so, these concerns are juxtaposed with how these issues affect the lives of Black Cubans. He emphasises in this second collection, the need for Cubans to recognise the duality of their society_Cuba as both Black and White.

\subsection{Blackness in Sóngoro cosongo (1931)}

From Motivos de son to Sóngoro cosongo, there is a manifest evolution in the language and scope of Guillén's poems. The poet changes from focussing on the details of the daily lives of Blacks to issues that affect Blacks in the broader socio-political and cultural setting of Cuba. However, there is also a sense of continuity of theme and vision between the 1930 Motivos de son and the 1931 Sóngoro cosongo. According to Lorna Williams, "the poet appeared eager to continue his explorations of the possibility of clearing a space for the expression of a distinctive cultural idiom, which he began the year before" ("Self" 160). The second collection takes its title from the chorus of one of the poems of Motivos de son, "Si tú supiera," in which the repetition of this phrase is part of the musicality of the poem, as will be seen when this poem is discussed in Chapter Four. Sóngoro cosongo is very significant in 
Guillén's work as a poet because, as Smart indicates, this book heralds "artistically complete affirmations of the African heritage" (69).

In this second book of poems, I argue that Guillén continues with his earlier project to bring Blacks and issues of Blacks to the fore and yet, surprisingly, he is described by many as a mestizo poet mainly because of the prologue of this same book. Guillén, then, continues to throw light on the issues of Blacks in this collection and, although the poet makes reference to mestizaje as we will see, in fact he distinguishes the two distinct races on the island. Guillén does not fall into the trap of conflating the races since he was well aware of the official rhetoric of racelessness used to repress the persistent tensions of race.

The collection consists of fifteen poems with an important prologue, that has been much referred to by critics as validating their view of Guillén as a poet of mestizaje. However, I will argue that in the prologue Guillén is working through the issue of how to articulate the way in which both Blacks and Whites can complement and complete each other in building the nation of Cuba. He did this by first articulating the key issue of the importance and the value that the Black component of Cuba brings to the identity of Cuba and the need for Blackness and Black lives to be accorded the same level and status as the White component. Indeed, Sóngoro cosongo has an exclusive focus on different aspects of Black life, although not as realistically as they are portrayed in Motivos de son. These later portrayals are mostly captured in poetic rather than realistic language. In this section, I will analyse this prologue, in addition to the first two poems of this collection, "Llegada" and "La canción del bongó" as they relate to the theme of Blackness. Before this analysis, however, I will briefly introduce the rest of the poems in the collection.

"Pequeña oda a un negro boxeador cubano" has already been discussed, while "Mujer nueva", "Madrigal 1" and "Madrigal 2" will be referred to in the next chapter on Guillén's representation of women. "Canto Negro" and "Rumba" are playful and jovial poems, creating 
an atmosphere of cheer and jubilation and representing Afro-Cuban dancing and music. The intensity of the rhythms are conveyed by the use of jitanjaforas - for example, "Mamatomba, serembe cuserembá," - expressions which imitate Afro-Cuban drums and musical instruments. These two poems capture the adroitness of the Black man and woman as they dance. In "Chévere," the title of which could be translated as "fantastic" or "great" in the rest of Latin America but as a "bully" or a "braggart" in the Caribbean region, a knife-wielding male figure slashes in anger at the moon, a song and a shadow, and a woman. In "Velorio de Papá Montero" the speaker recounts the exploits of the protagonist on his guitar, his drinking spree and his sad end, stabbed to death by an "ecobio"- - his religious brother. In "Organillo," a picture is painted of a black man who is forced to make ends meet by playing his street organ. On this occasion, the sound of the organ is dead- "la conga muerta en el organillo"and hence his source of livelihood is denied him that day. In "Quirino," the persona of that name, with his creole-guitar in hand interacts with a female black woman with thick lips ("bemba"). "Caña" recounts in a symbolic way the human degradation, socio-political and mental slavery which are all partly a consequence of the sugar trade and imperialism in Cuba. In "Secuestro de la mujer de Antonio" the speaker expresses his lascivious desire towards the mulata who is portrayed as lacking the agency to fight off his advances—“de aquí no te irás, mulata." In "Pregón," our attention is drawn to a very common situation, also seen in Armah's work, that of street vending. In this poem, the challenges that the Black street vendor faces are captured. Thus, as can be seen, the themes of the poems are not in fact related to mestizaje but rather to Black life.

Most criticism on Guillén's work focuses on him either as an exponent of Afro-Cuban poetry or as a poet of mestizaje. We have seen the former in Motivos de son, while the idea of him as a poet of mestizaje comes mainly from critical analyses of the prologue he wrote for Sóngoro cosongo. In this section, I contend that Guillén in Sóngoro cosongo should be 
regarded as "prophesying" the coming into being of a unified mestizo nation, rather than saying it has already being achieved. The possibility of this new Cuban nation is predicated on, as he wrote in his essays, the identification, addressing, and removal of certain racist ideas held by the elites about Cuba's Blacks. Guillén again stresses in these poems the distinct cultures of the Black community and the daily difficulties and discriminations that they suffer. I also maintain that the prologue to this collection of poems, that has been widely alluded to by critics to emphasise Guillén's mestizo disposition is in fact, as I will show, rather more aspirational and articulates a very particular and personal idea of mestizaje. He anticipates the day in the future when all Cubans will be treated equally without their distinct identities being subsumed or discarded and in the last sentence of the prologue he states, “estos poemas quieren adelatar ese día."

Guillén's conception of Cuban society is different from that of many other writers. In his poetry, he challenged Cuban society to accept the fact that the Black element was central to the social composition and identity of Cuba. However, since the African element was largely sidelined and discriminated against in the wider society, he deliberately emphasised this aspect of Cuba in his poetry in order to make Blacks visible and underscore their importance to this society. I will now critically examine the prologue and the various metaphors and symbols Guillén uses to articulate his ideas.

Many critics at the time, who had been conditioned by the national rhetoric of racial equality, were not happy about the voice and visibility that Guillén was giving to Blacks in his works. The poet alludes to some of these negative attitudes towards his poetry in the prologue: "[N]o ignoro, desde luego que estos versos les repugnan a muchas personas, porque ellos tratan asuntos de los negros del pueblo." He declared himself unbothered by such readers' opinions of his poetry because most of these people are not ready to accept the truth about the situation of Blacks in Cuba. In addition, in his opinion, these people seek to 
hide their own mixed race origins: "[H]an arribado penosamente a la aristocracia desde la cocina, y tiemblan en cuanto ven un caldero." As already mentioned in the prologue, his poems were repulsive to many people because of their focus on the issues of Black life in the poor neighbourhoods of Cuba. Indeed, in this address, the poet warns that "espíritus puntiagudos" should not go near these poems because they would not be at ease with the themes that they discuss, and their bodies will tremble when these themes are evoked. Guillén indicates that, although these may be good or respectable people, he does not care whether the poems offend them or not. Indeed, he expresses some pleasure if they are offended. Nevertheless, despite the focus on Blacks, and black life and culture, Guillén does assert that the poems of this collection are "versos mulatos"-conceived with Black elements but which address both Blacks and Whites with a view to highlighting the relevance of Blackness in Cuba.

In the next section of the prologue, Guillén sets out a number of metaphors to define his position on the issue of Blackness and the nature of the relationship between Blacks and Whites. These metaphors are those of "níspero," "cóctel," "hidrografía social," and "garfio". Most critics focus on the nation of Cuba being a whole and ignore the different components that make up the sum of this whole (the nation), hence their view of Guillén as continuing to emphasise the mestizo nature of Cuba when he refers to Cubans as "somos todos un poco níspero" and "nuestro cóctel."

The statement "somos todos un poco níspero" is at once a humorous one and a direct statement of equality. The image of the níspero or fruit of the loquat tree is telling. The níspero or loquat is composed of high sugars, acids and pectin and the delicacy of this fruit is most fully exploited when it is combined with other fruits. These substances readily mix when the loquat is combined with other fruits for a fresh fruit salad or in juice but it does not obliterate the other elements that make up the fruit salad or cocktail. That is, the elements do 
not dissolve completely into the mixture to form a solution. The use of "níspero" as a metaphor to describe Cubans has a three-fold implication. Firstly, Guillén's referral to Cubans as "níspero" and as a cocktail is a clear signal of the multi-layered and multicomposite nature of the Cuban socio-cultural landscape. Secondly, it emphasises the fact that no Cuban can actually claim to be of pure race since there is always a distinctive feature that will eventually show an aspect of Blackness or Whiteness in the person. Thirdly, by referring to the Cuban nation as "níspero", Guillén draws our attention to the fact that it is only in identifying the individual uniqueness of the races and then combining these singularities with others that Cubans can fully appreciate the value they add to each other. He reinforces this statement by suggesting that there is no pure blood, all Cubans are "níspero"- that is, they are either brown or some other shade of the colours on the spectrum from Whiteness to Blackness. In the colour composition of Cubans, there are perceptible features of both races and the resultant by-product will represent the future Cuban nation that Guillén proposes-a "níspero". It also reinforces the statement that the whole is greater than the sum of the parts. Blackness appreciated as it is, in its entirety-not just certain groups such as Black intellectuals, those with light skin and so on-would add more value to the nation of Cuba as a whole. Guillén uses the loquat fruit as a metaphor to stress the diverse socio-cultural composition of Cuba at the time of his writing and the way in which the races should be understood as coming together and encouraging each other, and bringing out the best in each other.

The next point Guillén makes emphasises his role as an engaged poet fighting for the equal recognition of the two races of Cuba: "[T] odos somos un poco níspero. ¿Duele? No lo creo. En todo caso, precisa decirlo antes de que lo vayamos a olvidar". He recognised the possibility of people forgetting the fact that there was a Black ancestor in their past and he chooses to remind everyone of this in his prologue. This reminder echoes the advice he 
proffers to Blacks in his essay "La conquista del blanco"- that Whites should be made aware of the fact that Blacks and Whites are the same under the skin.

Moreover, he goes on to make a strong argument about the ineluctable and inevitable presence of Blackness in Cuba: "[L]a inyección africana en esta tierra es tan profunda, y se cruzan y entrecruzan en nuestra bien regada hidrografía social tantas corrientes capilares, que sería trabajo de miniaturista desenredar el jeroglífico" (prólogo n.p). Here, Guillén uses the expression "regada hidrografía" to refer directly to the idea of a map of waterways. I suggest that this quotation emphasises the fact that the African or Black presence has taken root in Cuba. It is concrete and its roots go deep into the socio-cultural makeup of the nation of Cuba. In a significant way, the African presence intersects and intertwines with the wellirrigated social hydrography, forming capillaries. This outcome, in turn, creates the possibility of outflows from it, like streams branching out into other streams. This visual map or symbol—“jeroglífico"—would be difficult for a miniaturist to disentangle because of its complexity. In other words, it would be difficult to separate the various components even though each is visible on the map. Furthermore, there is also the suggestion that these waterways - "corrientes capilares"-are like blood vessels and capillaries, working independently but together in the social body of Cuba. They are mixed and connected but not merged in this process. Thus, the science of surveying of water bodies has been applied as a metaphor to the society of Cuba but also echoes the idea of blood lines. This metaphor evokes the value of unity-in-diversity that Guillén predicts at the end of the prologue. It again emphasises the fact that Cuban national unity in the future can only be achieved if the various constituent parts are combined in a unified and equal fashion but retain separate identities - with a rightful share of all the rights and privileges of the constitution.

The act of attempting to separate these intertwined social phenomena "sería trabajo," but it will be of little use undertaking this project since the way forward-building on the 
racial commonalities - is easier. Kutzinski describes the relationship that Guillén alludes to in his prologue as not being a matter of "assimilation but compenetration" (163) —an emphasis on interconnectedness but also on the maintenance of presence, dignity and respect.

The next section creates another image - that of islands connected by a hook-"un garfio submarino." In Cuba, the two races, from a distance, appear to be two distinct islands. Although the two races appear poles apart, separated from each other by the sea, they are united by a "garfio submarino." The two islands or continents are completely connected and secured by their strong underwater connections or bonds. They are not separate at all. In fact, the earlier the two races recognise this intertwining-connectedness and work towards an equal future for both races, the better it will be for the nation of Cuba, Guillén suggests.

As a result of all the above reflections, Guillén ends the prologue by referring to the Cuban spirit as mestizo. Perhaps, here, he is referring to the spirit of the independence wars where the combined minds, hearts and spirits of Cubans (Black and White) fought for the independence of the nation and the equality enshrined in the constitution. In addition, by stating that "por lo pronto el espiritu de Cuba es mestizo," there is an emphasis on the fact that Cuba's spirit is mestizo but the reality is yet to follow-this is an urgent call to collaboration among all Cubans.

Arnedo-Gómez argues that Guillén's rhetorical discourse on black and white unity is often undistinguishable from that of white afrocubanistas. He adds that his reference to "nuestro coctel" suggests Ortiz's "el ajiaco," and that Guillén's vision is one of homogenisation (xv). He and others argue that Guillén's "incapacity" to focus on a black poetry without seeking a mestizo nation is due to his family background, the European influences on his poetry, the literary circles he belonged to in Camagüey, and finally because 
"he is a learned and refined man" (xvii) ${ }^{28}$ However, as I have shown, it is clear that Guillén's vision is still highlighting the issues of Blacks. He is not necessarily declaring a mestizo nation at the time of Sóngoro cosongo, but rather the interconnectedness of the two races. In this collection, he therefore seeks to quicken the arrival of the day when "a united Cuba" ceases to be a theory or a spirit, but will be a reality. Ultimately, in this prologue, Guillén is trying to articulate and symbolise the nature of relations between Blacks and Whites in a future nation of Cuba where he hopes racial harmony will be achieved. In other words, he is seeking the right metaphors to express his vision for the future of Cuban society. However, before that distant future is attained in his poetry, he continues to address issues that affect Blacks, with the view that what affects Blacks also affects Whites due to the interconnectedness of the two groups - this most notably, is what he does in Sóngoro cosongo.

In conclusion, it is important to recognise two main points from the prologue. Firstly, Cubans should consider each other as "níspero", they should realise that they are all "cocktails" and that they are like continents that are secured and connected by strong links or root systems (a shared past and history). Secondly, and more importantly, the island of Cuba is not raceless, rather the two races are distinct but interconnected, Thus, Guillén is Cuba's poet of connectedness, rather than mestizaje. With this in mind, I now analyse two poems of the collection, which are particularly important in my view, in terms of their representation of Blackness.

\section{"Llegada"}

In the first poem of the Sóngoro cosongo collection, "Llegada," which narrates the arrival of the Black race in Cuba, we are introduced to the theme of migrancy, travel, movement from

\footnotetext{
${ }^{28}$ See Arnedo-Gómez's Uniting Blacks... for details on why many critics see the prologue as stressing Guillén's mestizo disposition.
} 
one world or geography to another. The first stanza describes the arrival of these "travellers" and the coincidental discovery of the humid word from the forest as the sun rises in their veins. The speaker declares that their fists are strong and capable of holding the oar. The second stanza recounts their journey: they see beautiful palm trees, they cry out at some point of the journey and their feet are strong enough to flatten the dust of the abandoned paths they tread. They know where the waters were born and they love these waters because they push their canoes forward. And all this happens as they sang along. The third stanza describes the things they bring with them to the new world: smoke, fire, knife, alligator, bows and clean spirit. They also brought their character and impact into the new world. The final part of the poem reflects their hopes and aspirations for the new place; the city awaits their arrival and men of old are ready to applaud their triumphant arrival and crown them.

Written in expository language, the poem tells us of an event, a happening. The silence at the beginning of the poem is broken by "¡Aquí estamos!”- an indication of the arrival of the Black man into a completely new world. This idea of spatial newness is replicated in the lines that emphasise the items that they brought with them, for example the alligators and the smoke-items that emphasise the specific forms of cultural expression of this group of people. The silence before the apostrophe also indicates a struggle that finally ends in "¡Aquí estamos!" This phrase is a victory song indicating the arrival after a long journey from their homes to the current location, not as slaves but as free people. Smart describes the phrase as "a strong poetic declaration that 'we shall overcome,' that 'we are somebody" (70). Indeed, they have arrived in Cuba where they are to share and enjoy the fruit of the land. The repetition of "compañeros aquí estamos" also suggests a reaching out process, showing who the Blacks are, and representing them as part of the country and also reassuring those with "ojos pávidos" who think Blacks are their enemies and, for that matter, a threat to the nation. The victory song at the beginning of the poem together with the line 
“Eh compañeros, aquí estamos” indicate their arrival as equal members of the society and White Cubans as their comrades - a reminder of what Guillén stated in his essays that Blacks should consider Whites as friends. The joyous ending of the poem attests to the joy of the arrival to the new land. In this poem, Guillén might be unconsciously adopting a principle similar to the sankofa principle used by Armah (and which I will explain in greater detail later) by going back to the past to recall the beginnings of collaborative work between Blacks and Whites during the independence struggle and reminding all Cubans of it so that they can once again build together, both Blacks and Whites.

In these lines of the third stanza, "Es como un músculo bajo la piel del alma, / Nuestro sencillo canto" we are introduced to the simple song of the arrival. This song has been transformed from its acoustic form into a tangible physical entity of muscles and skin. This transformation is an indication of the power in the song - this African song-which serves as a source of motivation for Blacks, not only giving them the physical strength to carry on but also the mental and emotional vigour which transcends the muscles to enter the very core of their souls. Moreover, this is an emphasis on the physicality of Afro-Cuban culture which we see in other poems.

The poem catalogues the African identity that the visitors bring to the new land. Typical African village essential articles such as "humo" and "fuego" are specifically mentioned for emphasis to portray Blackness in this poem. In an African setting, smoke and fire signify hope, life and vitality. The most notable statement the poet could be making about all these elements is the fact that they are brought into this new world with a well-intentioned mind, "el espíritu limpio". The poem concludes this stanza stressing the impact that Blackness will make on the new continent: "[T]raemos / Nuestro rasgo al perfil definitivo de América." The Black nation will remain visible and make a definitive impact not just on Cuba but on the whole continent of Latin America. In addition, this is a statement that serves 
as a reminder to anyone who is impeding the recognition and validation of Blackness in Cuba. The word "definitivo" is a statement of defiance, a declaration of the perdurance of Blackness that launches a challenge to the dominant imaginary of a raceless Cuban nation.

A critical examination of "Llegada" reveals that it was intended to describe and authenticate the arrival of Blacks to Cuba. This arrival to the new destination is not characterised by any compulsion and, thus, not referring to an arrival in chains. Rather, it is a new day in the history of the land and its people, and the city awaits them with its possibilities - this is the Promised Land with the Cuban Constitution as a key guide to this newly discovered land.

\section{"La canción del bongó"}

"La canción del bongó", the next poem in the collection referring to Black culture, has been analysed by several critics through various lenses such as the plurality of races, duality and syncretism of religions, evidence of santería in Cuba and so on (Cole 6, Arnedo-Gómez 160 and Martin 51). An anonymous speaker who repeats the title of the poem introduces the drum song to us. The song is a convocation from the perspective of the bongo drum-it calls every one to respond to it, even the most refined person quickly heeds its call. There are those who respond immediately and those who delay their responses, but the deep voice of the bongó drum calls both Blacks and Whites inexorably.

The next stanza reflects on the mulatto nature of the land: Saint Barbara (the Christian saint of thunder) and Changó (African god of thunder and lightning), and the presence of too many Dons, and those with Castilian titles, and those who are descendants of Bondósuggesting an African origin. It also highlights the fact that even though some people appear white outside, they are Black inside and vice versa - "pues quien por fuera no es noche, / por dentro ya oscureció" - and as such, Guillén suggests a bridging of the gap between the two 
cultures. The ending of this stanza, "y andamos de dos en dos" also intensifies the desire for unity, two peoples walking together, stressing the fact that even though they are separate, they are connected - a strong indication of the need for cooperation and collaboration between the two races. The poem evokes the dualities that exist in Cuba as the drum indicates that there are those who will insult him in public although privately they kiss him, but it also suggests that this difference will be resolved in the future. The future tense of the last stanza is significant since it reinforces the strong sense of inevitability of the yet-to-exist unity-indiversity that Guillén foretells in his essays. Here, the Drum-speaker calls those who publicly reject him brothers and predicts that in the future they will beg his pardon, they will eat with him, and they will agree with him and tap his back. They will also dance to his tune, and take a walk with him and they will all be together.

In this poem, Blackness is personified in the bongó drum, represented as the epitome of power and unity. Guillén endows the drum with a "profunda voz," a voice of authority when it speaks. It convokes and summons all, Black and White, to respond to it. The authority of this voice, which serves at the same time as the poetic voice, is evident: "responde, si llamo yo". Even though it is clear that there are different responses- "Unos dicen: Ahora mismo, otros dicen: Alla voy"-, this "profunda voz" "convoca al negro y al blanco, que bailan el mismo son" regardless of race or class. I argue that, indeed, Guillén perceives Black culture as a powerful unifying strand for Cubans when it is accorded its proper place in the socio-cultural life of Cubans. In line with this objective, he entrusts his future expectation of the recognition of Blacks and the unity-in-diversity of the nation of Cuba into the hands of the personified bongó drum. This drum is a superior and irresistible force that unites Blacks and Whites, but under Black culture. "La canción del bongó" may be the most mulatto of the poems of the collection but it still stresses Blackness as the important force. Blackness, I maintain, therefore, acts as a unifying and irresistible force of peace. It 
also points to the hope that one day, both the Black and the White races of Cuba will be united and responding to the same strongly African song. The "dos en dos" collaborative existence that was called for in "La canción del bongó" is explored meaningfully again in two poems of the next collection, West Indies Ltd.

\subsection{Blackness in West Indies Ltd (1934)}

This collection continues Guillén's project to represent Blacks in a positive light, making them visible and highlighting their role in forging the future united nation of Cuba, but it also stresses the need for collaboration and cooperation between Blacks and White Cubans and the fact of interconnectedness between them. To conclude this chapter on Blackness, I shall briefly analyse "Balada de los dos abuelos" and "Dos niños" which in my view are important since they demonstrate an extension of the ideas expressed in his essays and in Sóngoro cosongo.

\section{"Balada de los dos abuelos"}

"Balada de los dos abuelos" has received a wide range of commentaries and analyses already, and therefore, will only be briefly examined in this work in terms of the "abrazo final"- the coming together of the Black grandfather and the White grandfather. The poem tells the story of the narrator's two grandfathers, Taita Facundo and Don Federico, whom the poet indicates are like shadows accompanying him, but who are only perceptible to him. The first-person speaker of the poem from the first stanza tells us of the unique identities of his grandfathers, and later, in the same tone, narrates the experiences of the grandfathers. The speaker describes the very different circumstances that marked the arrival of the two grandfathers: the brutal nightmare of slavery and the dreams of the white colonist. After this description, the 
speaker explains how the two grandfathers have found each other because he unites them: "Yo los junto." This union then leads to the gradual thematic and formal removal of obstacles between these two men and their pasts as they embrace, sigh, and raise their heads until the final stanza of the poem where they are literally put on the same scale, level, and social status and sing together: "¡Cantan!”

Although the Spanish grandfather and his race could be blamed for the situation of his African grandfather, the poet does not show any discriminatory approach in his description of both of them but objectively states the facts of their experience. He expresses the challenges and the difficulties the black grandfather faced which led to his cry of "me muero" (I am dying), as compared to the shout of the Spanish grandfather-"me canso" (I am tired). Anthony Dahl indicates that Guillén "does not shy away from highlighting his black grandfather's pains and suffering as a slave" (11). However, it appears from Dahl's analyses that he equates the experiences of both grandparents by saying they were "fellow sufferers", which clearly downplays the Black historical experience. Arnedo-Gómez calls this an attempt to diminish "the white grandfather's role in inflicting the suffering of the African slaves" (97). However, upon a closer reading of his proposition, Dahl's concern seems rather to be that there is a reason for Guillén to believe that these two grandfathers should be united, and that he sees their pasts as a unifying point. This bringing together of the grandfathers is depicted in the final stanza.

In this final part of the poem, the poet emphasises the critical value of reconciliation and unity among Blacks and Whites for the future nation of Cuba. He therefore categorises the challenges faced by both races separately but similarly_- "ansia negra" versus "ansia blanca"-emphasising the fundamental importance of recognising the distinct races but, at the same time, making them work together for national unity, an echo of the "dos en dos" principle seen in "Canción del bongo". The final part of this poem reads as follows, 


\section{¡Federico!}

¡Facundo! Los dos se abrazan ....

los dos del mismo tamaño,

ansia negra y ansia blanca,

los dos del mismo tamaño,

gritan, sueñan, lloran, cantan.

Sueñan, lloran, cantan.

Lloran, cantan.

¡Cantan!

In the preceding lines, Guillén takes us on a journey though the lives of these two grandfathers whose final resolve to be happy depends on the elimination of all the obstacles to their unity. We witness here a systematic elimination of all the impediments to their happiness as they strive together, in their shouts, dreams, tears and songs. The final moment of gladness arrives when they can sing together: "iCantan!” This reinforces the future collaboration and cooperation between the races underscored in Sóngoro cosongo. However, it is important to question the ending of the poem and to resolve the issues of "preoccupations, doubts and the uneasiness symbolised by the shadows - 'sombras'—of the first verses of the poem, that the poet raises" (Dahl 12). The important question that arises at the end from the seeming lack of difference between the experiences of the two races is: does the word "cantan" symbolise an endpoint in the spectrum of discrimination between the two grandfathers? Guillén's prologue to Sóngoro cosongo makes the answer clear: these poems are predicting a hope for the future of the nation of Cuba where the two distinct races will live in harmony, but for now there is not yet an end to the discrimination and inequality between the two races. 
The exhortation at the end of the poem also indicates the joy that the poet would experience if he were able to accomplish the future objective of uniting the two "abuelos" by the power of his son, the Afro-Cuban song, so that they can work as one towards the peace and harmony of the nation of Cuba. The son, or song, is important here since this is the element that appeals to both "abuelos" and therefore is the only instrument that can bring them together at this historical moment. This crucial element, which is the essential ingredient for unity, is implied in the call of the son, just like the voice of the bongó discussed in the previous section. Guillén therefore conceives of Blackness and Black culture in this poem again as a uniting force for all. The need for unity is also expressed in the next poem, "Dos niños".

\section{"Dos niños"}

"Dos niños" is about two children whom the poetic voice describes in the first line of the first stanza as sharing a common background-"the tree of misery". These two children eat the same kind of food (scraps) from the same plate. The speaker describes the relationship between these two as a sincere and strong union in their current misery and asks the question as to whether they will also grow up together to be good men, Black and White?

The poem, in effect, explains the state of the nation of Cuba and its society-the social composition of Cuba and, more importantly, how the black element should equal the white element, without leaving room for the discrimination that has been encouraged by the dominant nationalist discourse of racelessness in Cuba. The reason for this sort of projection of equality is that, like the two children in the poem, who are described by Guillén as "ramas de un mismo árbol de miseria", the two races in Cuban society belong together and, when poor, suffer in the same way. The imagery that we see of the Black and the White child in the poem is that they both share similar socio-cultural circumstances of poverty, living like dogs, 
and are initially subject to the same condition of oppression. In this context, the "dos niños, uno negro, otro blanco" have to beg to survive, and eat like hungry dogs from the crumbs that fall from tablecloths of the rich as they are shaken out. There is a crucial call in this poem for the recognition by society of the sameness of the "niño blanco" and "niño negro" and for the underscoring of the importance of the two compatriots joining their energies together for the good of the nation - they live together, they are close to each other since they are joined together, their actions are the same and, like two good dogs, they suffer together as indicated by the following quotations. In the first stanza, "Dos niños, ramas de un mismo árbol de miseria, / juntos en un portal bajo la noche calurosa, /Dos niños: uno negro, otro blanco", in the second, "Sus cabezas unidas están sembradas de piojos; /sus pies muy juntos y descalzos /dos manos: una negra, otra blanca" and in the third stanza, "Están unidos como dos buenos perros". This is a reiteration of the point Guillén made in "La conquista del blanco"—Blacks should remind Whites that "somos de verdad sus hermanos". This desire for brotherliness and camaraderie in independent Cuba is particularly vital since the colonialist (Spain) and the imperialist (USA) do not distinguish between Black Cubans or White Cubans but rather exploit all of them in the same way.

The beauty of this future desired-for union and its consequences when the two recognise their unique but similar positions and work towards the improvement of their socio-economic situations is captured in “[iQ]ué unión sincera y fuerte!”. The expectations that the poet has for this union is clearly outlined here-a union that is sincere, without malice or prejudice and which strengthens both races. However, the poet asks a sincere question: "will these two children who are united in their misery and poverty fight together as well when the time comes, as two good men, Black and White?" This question remains unanswered but Guillén hopes the future of this union will be consistent with their present realities and anticipates that the two boys will grow in this sincere and strong union and, in 
addition, that they will grow into good men. This hope for future "good men" is very significant in Guillén's view of the issue of blackness since it will take a good black man and a good white man to build the nation of Cuba that he anticipates when he states "somos un poco níspero." In effect, it is also a call for these two children to grow together, not just in the bad times, but in the good as well, and fight together for the good of the nation, just as their grandparents did during the struggle for independence of Cuba.

\subsection{Conclusion}

The poems discussed above, I argue, were conceived with the view to accentuating Blacks and black culture and their relevance in the body politic of the nation. These poems also show a clear picture of what the future of a united Cuba, with Blacks and Whites working together in peace and tranquillity for an equal share of the benefits and privileges, could look like, as Guillén argued in his essays. More importantly, the power of the Afro-Cuban son and by extension Black culture and its authority over Blacks and Whites is underscored in these poems. Guillén will embark on similar objectives in other collections but these three are where these ideas are first laid out and therefore are the most important to this thesis.

Indeed, I argue, it becomes clear that the diversity of Cuban society in terms of the racial composition of the nation should not blind us to the interdependence of the communities and their close links. In pre-Motivos de son works Guillén argues implicitly for making Blacks visible in Cuba, that is, putting Blacks (Black men, Black women and the Black working class) centre stage and, in addition, encouraging and empowering them to recognise what they can do to help themselves. In Motivos de son, Blackness and black culture is made manifest so that Blacks can be proud of who they are and eschew self-hate and self-pity, and in Sóngoro cosongo Blackness and black culture serve as the only authentic voice that can truly forge unity among the races in Cuba. The emphasis on the need for 
cooperation and collaboration between the two races in Cuba is also continued in West Indies Ltd. Thus, the poems continue the main issues raised in the essays as discussed earlier.

All in all, when Guillén represented Blacks in the poems of Motivos de son, Sóngoro cosongo, and West Indies Ltd., it was to make them visible, reveal the situation in which they lived and to change the discriminated position of Blacks as belonging to, but not forming an equal part of the nation of Cuba. In short, he takes up a position as an engaged writer. Through these poems, Guillén has shown that Blackness and black culture are key to the future of Cuban society as it is the chain or the cord that will unite all Cubans.

In the next chapter, Chapter 4, I underscore the deliberate attempt made by Guillén to deconstruct the dominant unproductive representations of Black women in Cuba in the 1920s and 1930s. With a similar agenda of making them known and drawing attention to what they represent and their worth in Cuban society, Guillén reconstructs more assertive and progressive images of Black women. 


\section{CHAPTER 4}

\section{THE REPRESENTATION OF WOMEN IN GUILLÉN'S POETRY}

\subsection{Introduction}

This chapter examines what I argue is Nicolás Guillén's (re)constructive and empowering depiction of Afro-Cuban women in Cuba in his poetry from the 1920s and 1930s. I maintain in this chapter that in Motivos de son (1930), Guillén made a deliberate attempt to deconstruct the dominant unproductive representations of women and to construct more assertive and progressive images. This chapter consists of four main sections. Section One discusses various literary representations of the position of women in Cuba and specifically, of Black women, mostly by white male writers of the late nineteenth and the early twentieth centuries. Section Two presents an analysis of Guillén's representation of women in Motivos de son, and a later poem "Mujer nueva" in three subsections dealing with critics' views of his representation and my analyses of Motivos de son and of "Mujer nueva" in the second and last sections respectively. This section also counters some of the arguments advanced by Guillén's critics and establishes that Guillén's poems can be read as a reconstruction of the image of women towards a more assertive and progressive one. Section Three presents the conclusion to this chapter.

\subsection{Women in Cuban Socio-political and Literary Contexts of the $1920 \mathrm{~s}$ and 1930s}

Women's participation in Cuban history dates back to the early days of the Republic. Catherine Davies has captured this history in A Place in the Sun? Women Writers in Twentieth-Century Cuba (1997). She traces women's participation in Cuban history, giving a detailed account of women's representation in feminist movements, literary works and in 
society up until the advent of female writers in Cuba in the 1920s and 1930s. She posits that there were advances in women's rights in Cuba in the first and second decades but with an underlying current of a male desire to perpetuate "the modern, nationalist, post-colonial project" (Davies 13). She maintains that the 1901 Constitution of Cuba created an avenue for a women's movement, even though many of the reforms inscribed in it were unduly delayed (13). Education was expanded to include women (resulting in women making up $25 \%$ of enrolment in the University of Havana in the late 1920s) and a thriving Cuban feminist movement was set in motion, albeit constituted mainly by white middle-class women as Black women were not part of the early feminist movement (Davies 26).

According to Davies, the issue of non-representation or underrepresentation of Black women came up at the Third National Women's Congress in Havana 1939. Heated debates took place between the radical white feminist Mariblanca Sabás Alomá and the mulatto scholar Angel César Pinto Alboil. Pinto argued that Sábas had "no right to speak on behalf of black women or blacks". However, Sabás Alomá asserted that, as a woman, “she [had] every right to express her feelings of solidarity with black women" (26). She was accused among other things, of remarking that black women preferred white men to black men and of asserting that, "Cuba has always consisted of a majority of 'pure' whites and a minority of 'pure' blacks who lived together in peace" (27). Davies notes that

Black women themselves, of course, are not given a voice in this debate which confirms their double marginalization. But the fact that even an informed, radical feminist such as Sabás Alomá should endorse, albeit unwittingly, a racist, classist ideology in this way indicates how far attitudes would have to change in Cuba if discrimination were ever to be attenuated. (27)

There was also a certain perceived continuous "self-identification of the mother with the motherland" (48) at this time. In other words, the general perception was geared towards 
the effect that women stood for the nation of Cuba and many women reproduced this theme in various literary works: Dulce Maria Borrero ("The Rivers” (1912), Amable Sáez J., Venezolano ("The Flag" 1929) and Emelia Bernal (Layka Froyka 1925) (Davies 49). This perception was however not the focus of Guillén's work. He concentrated on the rather precarious position of the Black woman within this paradigm.

Claudette Rose-Green Williams ${ }^{29}$ defines women's role in 1920s and 1930s Cuba, particularly the role of Black women, as affected by systems of colonial domination such as their marginalisation and the underestimation of their capacity to effectively take part in the economic and political life of her country. These structures condemned them to a marginal social position as social actors ("Myth" 16). Similarly, as Williams argues, in the literary productions of this period the political role of women has been omitted or underplayed (17).

In terms of literary representation of women in 1920s and 1930s Cuba, this manifested largely in negative terms as most of these texts portrayed demeaning images of women solely as an object of male desire. In this unfriendly space, one mouthpiece for the discussion of women's issues called Minerva magazine was inaugurated in the first decade of the 1900s. Minerva was a bi-weekly magazine first published in Havana by elite Cubans of colour in 1910. In her study of the Minerva writers in an article entitled "Minerva. A Magazine for Women (and Men) of Color," Carmen Montejo-Arrechea highlighted the main agenda of this magazine, arguing that the paper committed itself to the formulation of an agenda for creating more awareness among women of colour, establishing strong homes, educating women and promoting national development (34-38). In addition, the women writers of the magazine emphasised the importance of family in the development of the nation of Cuba and underscored the important role of women in society. According to Montejo-Arrechea, the magazine committed itself to the formulation of an agenda that was

\footnotetext{
${ }^{29}$ This critic is known by different names such as C., Rose-Green Williams, Claudette RoseGreen-Williams and in her latest publication in the year 2000 as Claudette M. Williams.
} 
aimed at creating more awareness among women of colour of the need to have functional homes, and making them conscious of how relationships between men and women should be conducted at home. Furthermore, it had the goal of educating women and promoting national development (37). Historian María Sierra describes the magazine's ideology thus: "Minerva was strongly committed to the defence of the new family order and gender relations" (140). In specific terms, this new family is supposed to have a stable home with a husband and a father present for it to be legally recognised. Indeed, in order to achieve stronger family ties, these Black women writers of Minerva, according to Montejo-Arrechea, called for Black men not to fall into the trap of the whitening ideology and choose whiter partners over Black women (38).

A close examination of the literary production of white Hispanic male writers (as well as Black and mulatto, at times) of the late nineteenth to the early twentieth centuries reveals certain predominant trends in the portrayal of Black women. These writers commonly depict the Afro-Cuban woman as "a lowly and promiscuous person", "a lascivious mulata", "an ontologically sensual creature", a sinful, sensual negra or mulata and a seductress (Duke 23, Daigle 40, RoseGreen-Williams 17, Howard 125). These literary depictions of the AfroCuban woman led to the creation of unrepresentative and unrealistic images of her such that, over time, it became the "norm and even proved useful in the promotion of other sociocultural agendas" and ultimately resulted in her being "totally at the mercy of greater causes and male-dominated conditions and circumstances" (Duke 23, 24). In this manner, the woman of African descent in Latin America and in Cuba especially was, in most cases, denied her own identity and largely defined instead in terms of her sexuality. Based on these images, two perceptions about her keep recurring in these literary works: she is represented either as deserving of blame for the difficult social position in which she finds herself or, as some other writers have described her, a victim of her circumstances (Harper 104-08). 
Furthermore, in most of the literary works on the Black woman in Cuba in the 1920s and 1930s written by men, there is a deliberate attempt on the part of the writers to avoid developing the psychology of their female characters beyond the level that was accepted in society, as Duke observes (23). This calculated refusal to look beyond approved stereotypes in the representation of women, that is, beyond the predominant negative stereotypes, confirms that certain social misconceptions were accepted as the norm by the social classes to which these authors belonged. Some examples of these perceptions are the portrayal of women of colour as inferior beings, and the recurring image of the mulata as a tragic character who was unable to escape her doom (Duke 32, 34). Indeed, from the period of literature on slavery to that of the negrista poetry of the 1920s and 1930s, the representation of the Afro-Cuban woman did not see any significant change: she still occupied the position of the voiceless object rather than that of a human subject (Williams, "Self" 95). Thus, she played a subordinate and impersonal role as opposed to the personalised, dominant role of the male figure.

In explaining the negative sexual stereotypes associated with the woman of African descent, RoseGreen-Williams suggests that these (mis)conceptions about the sexual physiognomy of the Black woman are, in effect, an attempt by negrista writers ${ }^{30}$ to fight against cultural colonisation. ${ }^{31}$ She contends that "the use of direct references to the erotic body signs of the Black woman is viewed as a reaction against the euphemistic bent of the bourgeois discourse on sexuality", and therefore reflects "an implicit rejection of the image of the desexualized white angel, the ideal of the dominant Eurocentric literary tradition"

\footnotetext{
${ }^{30}$ Negrista is a term used to describe those writers whose works were about Blacks in their society. Some critics like Richard L. Jackson have however made distinctions between black negrista and white negrista writers arguing that the former were mainly interested in the black folklore and rituals and ignored the Blacks' suffering and failed to protest against racial prejudice and discrimination. For more on the various categories of negrista writers and their representations, see Arnedo-Gómez, Writing Rumba: The Afrocubanista Movement in Poetry (2006), pp. 11-14.

${ }^{31}$ See Zackodnik, The Mulatta and the Politics of Race (161) and Hubel and Brooks, Literature and Racial Ambiguity (50).
} 
(RoseGreen-Williams, "Myth" 17). RoseGreen-Williams also postulates that these texts reveal a subtle political agenda in that this practice of representing the woman as a sensual motif is a means of disguising the day-to-day reality of the Black woman, and served "to divert attention from her social dilemma" (17). However, I must point out here that, while these writers created an opportunity in their work to talk about the black woman and make her visible, unfortunately this portrayal in their works rather supported the socio-political agenda of glorifying the sexuality of the Black woman and denying other aspects of her humanity. For example, most of these poets use crude and animalistic terms to depict her and a pervasive but "insidious" sense of "racial discrimination" is brought to the fore in most of the texts that describe the Black woman (RoseGreen-Williams, "Myth" 17).

While the significance and importance of these negrista literary works should not be underestimated, more often than not, most studies tend to refer only to the work of these writers, which endorse the negative representation of women, and in the process, ignore more progressive portrayals of women in other poetry.

There were some attempts at changing the aesthetic representation of women over the course of the 1920s. In her work Charcoal and Cinnamon: The Politics of Color in Spanish Caribbean Literature, from 2000, Claudette M. Williams argues that the poem "La negra" (the Black woman), published in 1914 by the Puerto Rican poet Luis Lloréns Torres celebrates the intrinsic beauty of the Black woman, while "Elogio de la negra" (1925) by the Asturian poet Alfonso Camín gives a vivid description of the Negroid features of the Black woman that reflects her Cuban identity (31-2). This was the context within which Nicolás Guillén, as a Black Cuban poet, produced his Motivos de son in 1930. This collection of poems has been classified as Black poetry (Arnedo-Gómez xxix, 13; Szwed 67) to underscore its specific focus on Black lower-class sectors of Cuba and on their folklore. Through these poems, Guillén "undertakes a sustained program of aesthetic redemption of the black 
woman" (Williams, "Charcoal" 33). In the next section, I will review the critical stance of four main critics $^{32}$ and demonstrate my assertion that there was an intentional effort by Guillén to change the traditional and unproductive representations of women to more evolving and constructive ones.

\subsection{Critical Views of Guillén's Representation of Women in Motivos de son}

Guillén's representation of the Afro-Cuban woman in his poems has attracted the attention of a number of critics. While in his early poetry Guillén used what White calls "the European model" to construct an image of woman, what was lacking then was "the figure of the woman based on the African model" which was to come later in Guillén's work (80). He was however quick to add that, “[v]iewed in light of the negrista vogue some of Guillén's poems are at least dubious and indeed do very little to refute misconceptions of the rumba dancing, carefree Black woman" (81). This perspective particularly pervades much criticism up to the present because, as Adam Davis Miller an African-American poet, observed about the African-American writers of the 1920s "Afro writers often used the same stereotypes as white writers when portraying afros" (Cited in White 81). Hence, Guillén was often perceived as following in the same direction of debasing the Black woman in his poetry and deploying negative stereotypes. According to White, "[u]nlike the works of the negrista poets, however, Guillén has placed these questionable aspects of the Black woman within a very clear contextual framework," that is, the Black woman's response to, what White describes as "the relentless cycle of unfavourable economic circumstances," and her actions in this sense reflecting "a quest to survive" (82).

\footnotetext{
${ }^{32}$ I consider Vera Kutzinski, Gustavo Pérez Firmat, Conrad James and Gordana Yovanovich as the main critics on the theme of representation of women in Nicólas Guillén's Motivos de son (1930).
} 
Moreover, it is true that Nicolás Guillén was part of the literary and artistic movement of the 1920s and 1930s Cuba, and hence one would expect that he depicted some aspects of this literary and artistic way of expression of such a period - the negative portrayal of the Black woman and the disregard of "cultural interests of the large masses of Cubans" (Ellis, "Cuba's" 35). However, most critics overstate this position, in particular, in relation to their visions of Motivos de son. Referring to Richard Jackson's description of Guillén as a skilled manipulator of language to further the myth of Blacks as carefree, White makes the point that Guillén's use of language in his poems did "precisely the opposite-dispel such myths. In reality, they significantly reassess self-acceptance" (39).

This study takes a leaf from White's caution that "if a reading of Guillén is to yield a fully dimensional view of the Black woman whom the poet portrays, it must encompass more than a cursory and fragmentary glance at his works" (86). This study looks at the position of four major critics of Guillén's work and analyses these poems to arrive at a conclusion that, despite the negative readings the poems in Motivos de son have generated, there are progressive aspects of these poems that highlight certain empowering perspectives of the women they describe. These poems serve a double purpose in dealing with issues concerning the Black woman. As White forcefully argues, Guillén not only reveals "the plight of Black society in general, he specifically accents the problems of the Black woman, doubly oppressed in a society which insists that her womanhood renders her a second-class citizen" (87). I will also argue that these poems are part of a deliberate and sustained attempt by Guillén to provide a corrective to the dominant negative representations of women and construct more proactive and progressive images. 


\subsubsection{Critics of Guillén in relation to women in Motivos de son}

In this section, then, I will first provide an initial overview and a summary of the critical stance of selected critics of his representation of female figures in his Motivos de son collection. In section 4.2.2 I go on to present my own reading of some of the poems in his Motivos de son, in terms of their representation of Afro-Cuban women and use some of the arguments by the more favourably inclined critics to support my argument, as well as carry out a close analysis of the poems.

Two main strands can be identified within scholarship dealing with Guillén's representation of women. On the one hand, there are those critics who, though reasonably critical of his representation of women, only express mild concerns about them. Gustavo Pérez-Firmat, Conrad James and Gordana Yovanovich fall into this category. On the other hand, there are those who take a sharper critical stance against his representation of women. In this category, Vera Kutzinski is worthy of particular mention.

Gustavo Pérez-Firmat argues that the women represented in Guillén's madrigals ${ }^{33}$ and in Motivos de son serve as a source of inspiration and are "sometimes the subject of his mulatto verses" ("Mulatto" 91). Pérez-Firmat argues that the way forward in any analysis of Guillén's portrayal of women is to look at these poems in a positive light. To him, the women represented in them serve as sources of creativity for Guillén and there is no need to engage in a debate to determine whether Guillén's poems are machista or not. He further adds, with particular reference to the madrigals and "Mujer nueva": "I want to argue that these poems are interesting not only because of their portrayal of black women, but also because the woman they portray — the woman they invent—is Guillén's vernacular muse" ("Mulatto" 91). In addition, in line with his positive view of some of Guillén's poems, he contends that

\footnotetext{
${ }^{33}$ These are short poems on less critical issues/subjects. For more explanation of madrigal and its origins, see Firmat, The Cuban Condition: Translation and Identity in Modern Cuban Literature (1989), 91-92.
} 
through his poems, Guillén creates an entity that acts as the source of his indigenous inspiration. The implication of this assertion by Pérez-Firmat to me seem to be that the Black woman, as she is depicted in Guillén's poems, appears on the level of social reality as an authentic reflection of indigenous life and inspiration.

Conrad James proposes the need for critics to examine the representation of the women in the poems in the context of their relationship with men. He suggests that the poems should be appreciated not only in feminist terms but also in terms of male ego, male psychology, and male autonomy (64-67). For Gordana Yovanovich, Guillén's poems should be read as instances of play that involve male and female partners. In "Play as a Mode of Empowerment for Women and as a Model for Poetics in the Early Poetry of Nicolás Guillén", Yovanovich argues that Guillén's collection of Motivos de son displays a distinctive and progressive orientation in the form of positive energy that has not been adequately characterised by many critics. She contends that critics fail to recognise the necessity and the zeal on the part of the poems' characters to mitigate their suffering and to endure grim circumstances of oppression, starvation and humiliation. In addition, the Black woman is portrayed in this collection as showing resilience, as being spirited and competitive. Yovanovich's argument is that this black woman in Guillén's Motivos de son exhibits leadership over her male partner, and displays a healthy self-esteem. Furthermore, she is an agent of change who exercises her creative energies by appealing to her lover's desires and sensuality (Yovanovich 18). In so doing, the Black woman is able to create an avenue to display her dignity and humanity (16).

Conversely, there are critics who emphasise the problematic manner in which Guillén represents women in his work arguing that the poems of Motivos de son do not portray a positive image of women. Vera Kutzinski, for example, does not see any positive image of women in Guillén's poetry. She cites Motivos de son (1930), Sóngoro cosongo (1931) and 
West Indies, Ltd. (1934) as collections that fail to portray a positive image of women in spite of explicitly focussing on the mulata. Kutzinski suggests that "regardless of formal and thematic variations, ... these poems speak emphatically to what Teresa De Lauretis has called 'the nonbeing of woman"” (Kutzinski 164). However, I will argue in the next section that there are, in fact, strong indications of women's empowerment in them. In these poems, Guillén creates a window of opportunity for these women to be seen. By representing them, he puts them in situations that make their experiences visible to the Cuban society of the time. Furthermore, I will show that the Black female figure that Nicolás Guillén portrays also reveals an evolving identity as opposed to fulfilling an existing patriarchal stereotype. Thus, in his works, Guillén offers a more evolved and progressive representation of women, especially the Black woman in Cuba.

\subsubsection{Black women in Motivos de son}

Seven out of the eight poems in this collection focus on the representation of Black women in their socio-cultural milieu. I will argue that Motivos de son as a collection served as a vehicle that enabled Guillén to set in motion an agenda of refashioning the negative images of Black women into more liberating and empowering ones. In these poems, Guillén subverts the traditional representation of Black male and female relationships and of the Black woman herself, by allowing these women to speak out and encouraging them to work towards a better future. These poems focus on his conception of the Black woman and her interactions with her social milieu in order to highlight the impact of the socio-political setting on the Black woman represented in these poems.

\section{"Mi Chiquita"}

The first poem for discussion in this context is "Mi chiquita." Many critics have undertaken critical assessments of this poem as part of the whole collection of Motivos de son and, as 
with much of Guillén's work, it has been interpreted in very different ways. As Josaphat Kubayanda maintains, "it is doubtful that a single interpretation of Guillén's poetry will ever prevail, because there are at least two Guilléns: one "linked to the memories of the past, as well as to reflections on the social and racial destiny of blacks in a context," and the later Guillén (post-Revolution) who is "an apostle of the social experiment under Fidel Castro and has tied his creative activities to the ideas of the Revolution" (6).

"Mi chiquita" is written in the first-person singular voice and is from an assumed lower-class Black male perspective. The poetic voice captures snippets of the daily life of a lower-class Black couple. In this poem, the Black male speaker celebrates the qualities of his Black woman partner. The poem initially articulates the Black man's admiration for the Black woman as resting mainly on her domestic usefulness and apparent subservience: her good cooking, her washing and sewing abilities. However, as is demonstrated in the second part of the poem, the speaker highlights other aspects of the woman and, through them, we see a more empowering depiction of her.

The first four lines of the poem are an explanation of the speaker's commitment to his chiquita above all others: "La chiquita que yo tengo/ tan negra como e, /no la cambio po ninguna/ po ninguna otra mujé." The male speaker's use of the definite article "la" and the possessive adjectives "mi" and "yo tengo" in reference to his partner suggest the pride he has in his "chiquita." White interprets these lines as also reflecting Guillén's personal sentiments and impressions of Black women in general (White 91). However, these words might also be seen as suggesting a sense of possession. Kutzinski, as a feminist scholar, argues that the Black man's male chauvinistic tendencies are clearly shown in the line "la chiquita que yo tengo", as it gives one the impression that the "chiquita" has been reduced to a thing to be possessed (175). She further argues that the male speaker's attitude is in line with masculinist 
ideologies in the Afro-Cuban society at the time, limiting a woman's worth to her labour in the home (Kutzinski 175).

However, the Black man's pride and confidence in his chiquita is related in the first instance to the most important factor for him - "tan negra como e"- that is to say, her blackness. Even though Kutzinski maintains that, the male speaker's praise of the woman is silent on the most important aspects of her being-there is no reference to physical description except her blackness - this aspect seems to be the most important factor for him and part of his decision to remain loyal to this woman, rather than her domestic skills. These words from the male partner are significant since he validates his partner as worthy of admiration and creates awareness about her important role in the survival of the relationship and, above all, he emphasises and indeed boasts of her blackness. Furthermore, the Black male speaker of the poem could also be seen as taking a stance that goes against the predominant ideology of whitening, as discussed in my earlier chapter. He might have opted for possible social mobility by attempting to marry a white or lighter skinned woman but he did not. Rather, he accepted the Black woman as she was.

The following three lines of the first part of the poem celebrate the domestic qualities of the Black woman, “[e]lla laba, plancha, cose, /y sobre to, caballero,/ ¡cómo cosina!” Ian Smart is of the view that this "ideal romantic relationship" between the chiquita and the partner could be perceived as showing "a patent ordinariness or functionality" (141) since it appears to value mostly the specific domestic abilities of the woman. However, Smart adds that given the lower-class Black setting, the chiquita could be considered the ideal woman in this milieu, as she is able to meet the basic conditions of such a life (141). Yovanovich is critical of modern Anglo-feminist scholars such as Kutzinski who, she argues, believes that the highlighted domestic qualities denote the Black woman's subservience and, in 
Yovanovich's words, this “enrages the feminist reader conditioned by Anglo-American principles of equality" (16). ${ }^{34}$

Most critics of this poem (Yovanovich, Kutzinski, James) focus on whose voice or speech is projected in the poem. Kutzinski argues that Guillén's poem does not attempt to highlight the voice of the Black woman; rather, the Black woman's side of the story concerning the dynamics of the relationship, is gathered from the male speaker. To be more precise, the Black man reports the speech of the Black woman. While this might be seen as a manifestation of his power over her, equally, it could be viewed as a recognition of the power she has over him — the man acts as the mouthpiece of the woman. Furthermore, through him, the reader discovers what she demands of the man.

This is revealed in the second part of the poem where we appreciate a different aspect of the Black woman who in fact exhibits control over her partner and he shows a subservient attitude towards her:

Si la bienen a bucá, pa bailá,

pa comé

ella me tiene que llebá,

o traé.

Here, Guillén shows a reversal of the usual practice where the man takes the woman along whenever he is going out. In the poem, the male/female role, in terms of control over movement, is reversed. Clearly in this instance, therefore, the worth and power of the Black woman is not limited to her labour at home. Guillén's portrayal of the woman as occupying a position of power here is significant since the poetic voice of the man is made to express the

\footnotetext{
${ }^{34}$ Yovanovich also opines that these Anglo-American feminists will be infuriated by the title of the poem because "the diminutive [chiquita] belittles the adult woman to which it refers" (16).
} 
Black man's insufficiency and inadequacy — "if they come to look for her, she has to take me along with her."

The next stanza, which attracts various interpretations, is as follows:

Ella me dise: mi santo,

tú no me puede dejá;

bucamé,

bucamé,

bucamé,

pa gosá.

Even though the beginning of this stanza-"ella me dise: mi santo,/ tú no me puede dejá"could be read as a male chauvinistic patronising way of talking, upon a closer reading, the two phrases above in fact show the power or control of the female over the male. The Black woman in the poem indicates to the man (even though this is communicated indirectly through the male speaker), "you cannot leave me; that decision has to be taken by me". This brings to light the weakness of the male speaker in the poem, which can read as reflecting women's power, or this woman's power at least, and indirectly reveals an empowering of women of some kind.

The male cannot leave her and must look for her "pa gozá". The repetition of "búcame" three times shows the importance of this search and the effort that he must make in searching for the woman as it is not just a one-off search but a continuous one. The repetition also reveals the dependency of the male on the woman and reinforces his helplessness as we will also see in "Tú no sabe inglé." Moreover, it reveals the source of the woman's powerthe sexual attraction that she exerts over the male. James also reads the above stanza as an attack on the male ego-revealing male insecurities rather than merely envisaging the poem as an expression of Black sexism (64-67). Yovanovich on the other hand, argues that the 
Black man and the woman in this poem are in a situation of co-dependency (16) and concludes that in this poem, even though the woman is partially submissive, the greater part of her is in a position of power over the man (18).

As I have argued, Guillén recasts the dominant repressed and silent position of the woman through her portrayal as being in charge of their relationship. I also emphasise that the poem draws our attention to other aspects of the woman, not just her domesticity, and, through them, we appreciate a more empowering depiction of her. In addition, I have highlighted the fact that through this poem, we establish the Black man's pride and confidence in his chiquita. In this way, we see Guillén attempting to construct a more powerful image of the Black woman in contrast to previous representations.

\section{"Búcate plata"}

Another poem that brings up the issue of power in male-female relationships and appears initially to depict women in a negative way is "Búcate plata". In this four-stanza poem, a Black woman demands that her partner take an action to find a job and earn some income for the upkeep of the home because of the harsh economic conditions in which they live. She threatens to leave if the situation does not improve. Her threat to leave him, however, will incur the wrath of society who will treat her as a bad woman, only interested in material goods. The Black woman's appeal to the man does not yield any immediate results within the poem.

The poem starts with a repetition of the title and we read "búcate plata" three times in the first stanza, clearly portraying an urgency that has to be resolved quickly:

Búcate plata,

búcate plata,

poqque no doy un paso má: 
etoy a arró con galleta,

na má.

The repetition at the beginning of the poem captures our attention and directs the reader to reflect on the severe financial difficulty facing the couple. The reason for this urgent call comes immediately after the repetition: "poqque no doy un paso má: / etoy a arró con galleta / na má," a confirmation of the poverty and hunger the family is experiencing.

The next stanza presents the woman as understanding the socio-economic situation of the family:

$$
\begin{aligned}
& \text { Yo bien sé cómo etá to, } \\
& \text { pero biejo, hay que comé: } \\
& \text { búcate plata, } \\
& \text { búcate plata, } \\
& \text { poqque me boy a corré. }
\end{aligned}
$$

Her comprehension notwithstanding, the man has to do something about the present situation because "hay que comé." Again, in order to place emphasis on what should be the priority, she repeats the leitmotiv of the poem - "you should go and look for money"-insisting on the fact that her partner play the traditional role of the male as the provider of the home and the supplier of money (Lassiter 54, McGoldrick et al 207). Readers, as well as members of her own society, could interpret these demands by the Black woman, as the result of an excessive love for money on her part, but in the context of the poem, it is stressed that it is for the good of the family - there is no food.

The last line of the second stanza shows a possible resolution and the implication of the outcome for both parties. The woman threatens him, saying "poqque me boy a corré", thus asserting her power to break out of the situation she is in by leaving him. This option is delicate given the socio-cultural setting in which she finds herself: "Depué dirán que soy 
mala, / y no me quedrán tratá, / pero amó con hambre, biejo, / ¡que ba!” People outside the relationship will not appreciate the hardship that she faces but rather, a masculinist and patriarchal society will perceive her as una mujer mala (a bad woman) and treat her as an outcast for threatening to leave the Black man and her family home and she is aware of this situation. However, the fact that she was able to make that statement shows her resilience and determination in the face of difficult circumstances of lack and prejudice. Importantly, in spite of this likely social perception of the woman's actions, which affirms male dominance and female subservience, Guillén creates a feminine poetic voice so that the woman can express what goes on at the level of her own social reality.

In the last stanza, the Black woman enumerates the types of goods available in society if one has the money to buy them:

Con tanto sapato nuebo, ¡qué ba!

Con tanto reló, compadre, ¡qué ba!

Con tanto lujo, mi negro, ¡qué ba!

Critics have analysed her admonition to the man and the subsequent mention of these goods in two possible ways. Either, on the one hand, she is justifying the reasons why the Black man needs money, mostly that there are various kinds of goods — shoes, watches, luxuriesavailable in society which she also desires and her deprivation of these goods is emphasised by the refrain "iqué ba!" and thus, some interpret her as greedy.

On the other hand, some read the lines as meaning that the man has been spending all the money he had on these luxuries rather than on the family and the woman is expressing her scorn. As Ángel Augier indicates: "[L]a negra está decidida a no dar (un paso más) con el 
hombre que la tiene 'a arró con galleta, / na má,' mientras él luce tanto zapato nuevo ... tanto reloj" ("Notas" 125). For that reason, the woman will not suffer quietly and hence her decision to speak out against the man's indolence (Ellis, "Cuba's" 70). Ellis, however, argues that the issue of lack is not created by her "lover's misuse of money but his lack of it" (Ellis 70). On the issue of the Black woman being labelled as greedy, White is, I believe, correct when he remarks that "the apparent greed of the Black woman is indeed simply that: 'apparent greed'". However, even if it were true that she was greedy, "Guillén does not condemn her acts but makes us recognize the reason for them" (White 89). I argue that necessity rather than greed is at play here and in this situation the Black female protagonist, by deciding to speak out against her present circumstances, adopts a position that will, hopefully, help her in feeding the family and, at the same time, allow her to enjoy what society offers.

Yovanovich interprets the poem as focusing on the micro (domestic) world of the Black man and the Black woman (19-20) and emphasises the Black woman's rejection of hunger and poverty. She also reads the poem as stressing a mutual relationship between the two partners based on the terms of endearment that we see in the poem: "biejo", "compadre", “mi negro." Her reading recognises Guillén's attempt to create an image of the woman as a valued partner in the relationship.

Guillén portrays the Black woman as an assertive person, someone who commands respect in the eyes of her partner. She indicates to the man what he needs to do to enable them move out of the difficult economic situation in which they find themselves and also to keep her by his side. As already indicated, even though the woman's comments on their economic situation do not appear to yield immediate results, through this poem Guillén provides his female character the opportunity to express herself and she does so firmly. 
Furthermore, one could interpret the courage of the Black woman speaking out here as a resistance to oppression from the Black man and from hunger.

This poem, I argue, is part of Guillén's attempt to project the voice of the Black woman that had been silenced in most literature of the 1920s and 1930s in Cuba as already discussed. Furthermore, and crucially, not only does she have a voice but also she is giving an order. From a subservient and voiceless position in most earlier literary works, Guillén raises the voice of this woman to confront male hegemony and resist oppression and poverty. This goal is clearly articulated from the very title of the poem in the leitmotiv "búcate plata"-making a demand and giving an order. Thus, I maintain that the poem reflects a Black female image that is progressive and productive due to its emphasis on the power and assertiveness of the Black woman.

\section{"Hay que tené boluntá"}

Again, we have an unidentified male first-person narrator addressing his female partner in this poem from the first line of the first stanza to the last line of the second stanza. The next line (line 13) appears to have a different speaker since the tone and mood of the poem changes here-from a more forceful and commanding voice to sober, encouraging and compassionate tone in which the speaker addresses the Black woman. From this line on (line 13), this new speaker, also speaking from a first-person position, addresses the Black woman, encouraging her to be resilient in times of difficulty.

In the midst of difficult circumstances at the start of the poem, the male speaker of this poem declares unequivocally to his partner, "you know me, we do not have to waste words on this issue, and there is nothing for us to live on":

Mira si tú me conose, que ya no tengo que hablá: 
cuando pongo un ojo así,

e que no hay na;

pero si lo pongo así,

tampoco hay ná.

The situation becomes complicated in the following stanza when he commands his partner to pawn her electric iron in order to get money for his own purposes (Arnedo-Gómez 71):

Empeña la plancha eléctrica,

pa podé sacá mi flú;

buca un reá,

buca un reá,

cómprate un paquete vela

poqque a la noche no hay lu.

The worst part of the situation is that even though the Black male speaker is well aware of the financial needs of the family, his only preoccupation at the time is his own personal luxuries since it becomes clear that the proceeds from the transaction of the electric iron will be used to buy a suit. In addition, he is suggesting taking away the only instrument left with which the Black woman could eke out a living - the iron. Moreover, it could be deduced from the poem that the electricity has been cut off presumably because the bills have not been paid and probably because the speaker did not pay them. One might have expected him to be giving out money for the bills to be paid and electricity to be restored, rather than commands. In his selfishness, he further urges the Black woman to look for money and to buy a packet of candles (line 11), which metaphorically means she should prepare for emergencies that might beset them.

At the end of the poem, the new first-person, a narrator-turned-observer, encourages the Black woman to work harder. This is because, to the speaker, the difficulties of the 
present moment will soon be resolved and her bad luck will not last forever, “¡hay que tené boluntá, /que la salasión no e/ pa toa la bida" (Hay que tener voluntad porque la mala suerte no es para toda la vida). Moreover, the Black woman (a symbol of all Black women) is particularly encouraged to move on, and not to cry, to try all the options available to her“ben p'ayá/ ben p'acá”—and to keep trying to make progress each day.

There is a recognition in this poem of the difficulties the Black woman faces in her quest to survive, including having to deal with an inconsiderate partner who lacks initiative as to what should be done in order to solve to these problems. The recommendation of the narrator is to: "camina, negra, y no yore/ camina, y no yore negra". The difficulties of the patriarchal masculinist society and poverty will make life difficult for her but eventually, a brighter day will surely come if she has the desire to succeed. This is a call to emancipation, to keep striving for her own betterment. White reads the poem as emphasising " $\mathrm{t}] \mathrm{he}$ inescapable financial burden the Black man [woman] suffers" (40), hence Guillén's appeal to her not to cry but to "camina, camina."

I maintain that the Black woman in this poem is called out of submission into a potential future liberation through her own hard work. The poem acknowledges the fact that some male Blacks, as in the case of the speaker in this poem, have assimilated the clichéd dominant ideology of Black males being lazy, irresponsible and seeking opportunities to milk anyone dry, including their partners (de la Fuente 324, Allen 172, Hamilton 105). However, the way out for Black females is a change of mind-set, taking on board encouraging messages such as "Camina, negra, y no yore, /camina, y no yore, negra, /que hay que tené boluntá!" Certainly, there is hope for the future for the Black woman if she is determined and resilient, and this poem encourages the acceleration of her progress towards that day. 


\title{
"Si tú supiera..."
}

This poem is written from a first-person Black male speaker's perspective and in it he laments the conduct of a former Black female lover. The main ideas of the poem are the male speaker's desire not to be seen by the Black woman, his allegation that the female partner will "betray" her new lover and that this betrayal and eventual abandoning of her earlier relationship is, according to him, due to the Black woman's desire for money. All these views are found in the first two stanzas of the poem, which consist of four lines each:

¡Ay, negra,

si tú supiera!

Anoche te bi pasá

y no quise que me biera.

\author{
A é tú le hará como a mí, \\ que cuando no tube plata \\ te corrite de bachata, \\ sin acoddadte de mí.
}

In the first stanza, the Black man tells the Black woman that he saw her passing by the night before but did not want her to know. In the second stanza, the Black man explains to readers that he thinks the Black woman left him for another person (with more money). He further explains that his reasons for hiding and stalking her is that the woman will conduct herself in the same manner in the next relationship as she did with him when he did not have money. An alternative reading would be his possible obsession with her. The last line of this stanza also expresses his self-pity that she does not remember him any longer.

The remainder of the poem, which contains seemingly incomprehensible words called jitanjáforas, evokes the negra dancing the night away, now in the company of another man. 
A reading aloud of this last part of the poem clearly brings out its musicality through the rhythms of the jitanjáforas in the lines:

\author{
Sóngoro cosongo, \\ songo bé; \\ sóngoro cosongo \\ de mamey; \\ sóngoro, la negra \\ baila bien; \\ sóngoro de uno, \\ sóngoro de tré. (11. 9-16)
}

This rhythm calls to mind the sound of the bongó drum normally used in the performance of the son. Guillén incorporates this element here for the first time in his poetry and later uses it as the title of his second collection of poetry Sóngoro Cosongo ${ }^{35}$ and it has been the subject of much critical analysis in Afro-Euro-Antillean poetry. ${ }^{36}$

The rhythms and the form of the last stanza also draws our attention to the centre of attraction at this stage of the poem: the Black woman dancing. The composition of the last stanza suggests that a different voice from that of the male speaker's (presumably that of the audience at the dance) comments on what happens at the party grounds. The audience remarks that she dances well to the rhythm of the bongó drum. Although the poem commences with the assertion that she is bad, here she captures the attention of the audience depicted in the poem. The comment by the audience,_- "la negra/ baila bien"-connotes the idea that the negra has attracted attention to herself, while the speaker has been marginalised and kept on the outskirts. Indeed, the positive public attention that the negra attracts to

\footnotetext{
${ }^{35}$ For more explanation on the use of the words "sóngoro" and "cosongo," see Roberto González Echevarría's article "Guillén as Baroque: Meaning in Motivos de Son" Callaloo (310-14).

${ }^{36}$ Cossío Esturo opines that jitanjáforas are used to attain certain rhythmic effects (Esturo 28), while Ellis emphasises their peculiarity, which lies in the fact that they belong to "parole and not langue" and "may connote but cannot denote" (67). Isidore Smart indicates that these forms of expressions were used by "the culturally Euro-Antillean poets as a short cut to 'hablar en negro de verdad,' and naturally, there is an abundance of jitanjáforas in their works" (Smart 53).
} 
herself could be the reason for his decision to deride her (unsuccessfully) in public. This could be interpreted as a situation of sour grapes - he has adopted a negative attitude to the Black woman, criticising her because he cannot have her as a partner now.

I interpret this poem as a continuation of the situation described in "búcate plata," depicting what happens after the woman finally decides to leave the relationship because the man did not have money. Again, this poem reveals the Black man's helplessness without the support of the Black woman, as confirmed by his lament that the woman left him without a second thought: "te corrite de bachata, / sin acoddadte de mí" (lines 7-8). This poem is also the reversal of the situation in "mi chiquita" in which anytime anyone comes to look for the Black woman for outings or dancing, she takes the Black man along. In this poem, this Black man is left to one side, he is abandoned so to speak and, not wanting to disgrace himself"no quise que me biera," - he does not call out to her. The woman in this poem exhibits her freedom of choice and freedom of association, no longer tied down to a Black man who will not provide for her. This is an empowering position especially when one takes cognisance of the traditional subservient position the woman is represented as occupying in Cuban society of the 1920 s and 1930 s.

The remaining three poems that refer to women are "Tú no sabe inglé," "Mulata," and "Sigue..." The first two I consider to have more to do with the issue of Blackness and, as a consequence, have dealt with them in the previous chapter but to some extent, they do also depict issues relating to Black women.

In “Tú no sabe inglé” for example, Guillén empowers the Black woman by giving her a voice to express in unequivocal terms what she thinks of her interlocutor Bito Manué's relationship with "la mericana." Through the female speaker of the poem, we get the sense of the prevalence of the issue of status, especially social and racial whitening in Cuban society and a condemnation of it. This condemnation of Bito Manué's desire for social mobility is 
also emphasised by the five repetitions of "no sabe inglé", and the consequent anger that the Black woman expresses about it.

The most important aspect of this poem is the psychological "advantage" that the female character exhibits over the male character. James interprets "Tú no sabe inglé" as a psychological shift of power from the male character to the female. He argues that in the poem, the male character's lack of linguistic competence makes him vulnerable to the American woman and prevents him from asserting his power and seducing her, at least verbally. Moreover, he is silent in the poem, he may be ashamed, disgraced or again, lack the communication skills to even defend himself before the woman who mocks him.

In "Mulata," already discussed in the previous chapter, Guillén echoes the issue of racial pride and empowers Black women when he allows the Black male speaker to say in the final stanza

Si tú supiera, mulata,

la veddá,

¡que yo con mi negra tengo,

y no te quiero pa na!"

This declaration by the Black speaker that his negra is sufficient for him reiterates the view of the Black speaker of "mi chiquita." Through this poem, Guillén presents the Black woman as appreciated and accepted, as someone to be loved and not taken as a mere object or rejected as too black.

The final poem "Sigue..." has not been included in the analyses of these poems, neither under the theme of Blackness, which it does not touch upon, nor under that of the representation of women because the woman character portrayed in it manifests only the powerful sexual woman who has the potential to ruin men, in a larger social context. This 
image does not have a positive implication for women hence the exclusion of this poem from this study.

\subsubsection{Image of a black woman in "Mujer nueva"}

Another poem from a later collection of Guillén's poetry that addresses the issue of the representation of women is Guillén's "new woman" or the "Mujer nueva" as it is entitled. In this sub-section, I examine "Mujer nueva" from the collection Sóngoro cosongo of 1931. I chose this poem from this collection because, in my view, it represents a step further in the characterisation and representation of women by Guillén portraying an even stronger, affirmative and empowering image of these Black women than those in Motivos de son.

The title of the thirteen-line poem, "Mujer nueva", underscores the poet's intention of redefining and recreating the image of the woman. From this title, we get the sense that the poet is proposing a specific template or a model that brings together all the traits seen in the women who have appeared in his earlier poems in Motivos de son. The title also captures the poet's embodied vision of a new woman who will perform a specific role, which would lead to a more positive position for women in society. Smart opines in "Mulatez and the Image of the Black mujer nueva in Guillén's Poetry" that "Mujer nueva" is more than a title: "[I]t stands as an apt description of the new poetic persona that began to grace Guillén's poetry" (379). He indicates, "[t]he mujer nueva, in contrast to the female poetic personae that preceded and some that followed her, is black" (379). This is a confirmation of Guillén's objective of working towards changing the negative image of Black women and, in that way, helping to empower them.

The first stanza introduces us to the "negra" who is the "new woman" and who wears a light snake dress. This new woman is portrayed as having the full circle of the Equator tied around her waist like a small world: "Con el círculo ecuatorial, /ceñido a la cintura como a un 
pequeño mundo, /la negra, mujer nueva, /avanza en su ligera bata de serpiente". Without warning, we are introduced in this stanza to a powerful Black woman who has the capacity to change the world she is entering. Through the words "con el círculo ecuatorial", the poem also reveals that the specific geographical landscape that the poet links the Black woman with is the continent of Africa. This poem is a deliberate attempt to introduce a concept that is different from what pertains to the normal aesthetic discourse: an attempt to "displace the dominant Eurocentric aesthetic discourse that focuses on colour" (Williams, "Charcoal" 34).

The second stanza emphasises the regal nature of this new woman, portrayed as bedecked with a crown of palms, described as a goddess and as bringing the "new word." Here, Guillén uses the orthodox metaphor of the leaves of the palm tree, which is a symbol of royalty and homage to describe the woman protagonist. ${ }^{37}$ The critic Pérez-Firmat interprets the use of the palm leaves as Guillén representing the black woman in "Mujer nueva" as a being who is in close connection with the natural world, what he calls, "Guillén's native muse" (91-93). This is a view that Smart seems to corroborate when he indicates that the Black woman is depicted as Mother Earth, mysterious and alluring in her beauty (Smart 136). ${ }^{38}$ I agree with Pérez-Firmat's and Smart's interpretation of the Black woman serving as an inspiration for Guillén and as representing "the mysterious and the beautiful," but I resist the view that the "mujer nueva" represents mother Earth. For me, she is a spectacular Warrior Queen arriving in the New World. In this same stanza, she is portrayed as having a strong haunch and carrying with her a voice, a tooth, the morning and the leap.

Coronada de palmas, como una diosa recién llegada, ella trae la palabra inédita, el anca fuerte,

\footnotetext{
${ }^{37}$ A Biblical allusion could also be read into this usage, referencing Palm Sunday's triumphant entry of Jesus Christ into Jerusalem where palm leaves were used to decorate his passage.

${ }^{38}$ An explanation of the Black woman's designation as representing the Earth mother, Mother of the nation of Cuba has been given in the historical background chapter.
} 
la voz, el diente, la mañana y el salto.

This Black woman is "una diosa recién llegada" — a goddess who has just appeared in the New World. Guillén celebrates the majesty of this "mujer nueva" and heralds her arrival with all the pomp and splendour that accompany kings and queens when they salute their subjects. Another significant aspect of her appearance and arrival is the depiction of her as possessing the "palabra inédita," the unadulterated and previously unspoken word-the pure, life-giving, and uncontaminated word-a new perspective, so to speak. It appears that Guillén in these lines opens up new spaces and dimensions from which the Black woman should be looked at and appreciated. She is also depicted as having, in addition to a new, fresh word, an enthusiastic and energetic force that pushes forward with an agenda of demanding and reclaiming a voice for women and ensuring that they are empowered to speak. Moreover, the "palabra inédita" also evokes the image of a woman capable of acting as the spokesperson and advocate of all Black women who have not yet spoken. In other words, in this poem therefore, we are presented with a Black woman who is full of internal potential energy. Even though this energy might appear latent, it has a creative force within it.

The reference to "el anca fuerte" (the strong haunch) refers to the Black woman's physical strength, which was a widely accepted notion in the nineteenth-century Cuban narrative pertaining to Black women. Critics have rather ignored the positive aspects of this woman's "anca fuerte," and often, negatively associate her strength with savagery (Barrow 105, Beckles 10), and being a beast of burden like an ox or a cow (Jackson 49, Hord and Scott-Lee 96). Although these critics might argue that Guillén's use of “anca fuerte" points to his perpetuation of these negative images of the Black woman and hence that he is continuing in the misrepresentation of women, I argue that in historical terms, the "anca fuerte" could just mean the Black woman's capacity to withstand hard physical labour and the difficult conditions in the plantations during the period of slavery. In addition, the royal images here 
are not linked to animalistic ideas, and therefore, negate such a perspective in Guillén's work. As Smart proposes, the images portrayed of the mujer nueva in this poem are "evocative, not provocative like the images of the Afro-Antillean poets" (131). Moreover, Guillén, he argues, "can draw on the intense evocative charge contained in these images without descending to the clichéd expressions of his peers" (132). I read these lines as the woman bringing an urgency and purpose to the new word (of women's empowerment and liberation) through her untiring strong haunches and delivering her message. These haunches are a necessary condition for the task at hand, the carrying of the message to all places.

We observe from the poem that the mujer nueva brings the new word, together with her strength, and a list of possibilities and talents. These include her voice- - she is no longer silent-morning and her leap forward, indicating progress. The reference to bringing the morning with her can be read as meaning that she brings with her a new day, a new nation, one that has the capacity to recognise the role of women and support their leap forward (and the nation's).

The poet does not just depict one part of her-her sensuality-but also all the necessary parts that emphasise her persona: tooth, skin and blood, symbolising her unique being. It is also an indication of her capacity to regenerate, to reproduce her kind. In this context, the Black woman is not objectified, but portrayed as possessing physical, moral and spiritual substance. The tooth she brings along could signify her youth, or the significant and biting truth of the message she carries as "diente" immediately follows "la voz" in the phrase, "la voz, el diente, la mañana y el salto."

The third stanza explains how this new woman is full of young blood and has an untiring foot for the steady steps that will dance to the beat of the drum: "Chorro de sangre joven, /bajo un pedazo de piel fresca, /y el pie incansable, /para la pista profunda del tambor." The stanza above portrays her as having "young blood pumping in her veins" - a sign of 
youth and vitality. She is also depicted here as possessing the necessary skill and balance to dance to the beat of the drum. Her adeptness at dancing to the drum at the end of the poem could also be interpreted as an African attribute. Having started on an African note with "el círculo ecuatorial," the poem concludes on another African note, "la pista profunda del tambor."

Guillén depicts the mujer nueva as a strong-willed person, a warrior queen, a representative of all women who took part in the Wars of Independence and of all Black women of the new Cuban nation. Unlike the older version of woman represented in the earlier works of negrista poets of 1920s and 1930s, Guillén presents us with a woman who would stand and defend the rights of all black women and make their voices heard. I argue that the determination of this new woman to see a change in the condition of women is implied in this poem.

Indeed, "Mujer nueva" is distinct in the sense that it heralded the arrival of the new woman that Guillén creates. The possibility of the spectacular appearance of this new model of a Black woman is celebrated in this poem. This mujer nueva exemplifies the future of Black women, in the new nation of Cuba that Guillén depicts in his poetry. Clearly, the image of the Black woman portrayed in this poem is that of a talented and a gifted being who has a purpose: to proclaim the value of all women she embodies.

\subsection{Conclusion}

This chapter has analysed Nicolás Guillén's representation of women in Motivos de son taking into consideration the varying interpretations and criticisms of his work. In examining Guillén's literary portrayal of women, specifically Black women in his poetry, I have demonstrated that in writing Motivos de son, Guillén creates a particular representation that 
will serve as a springboard for (re)presenting a more progressive and empowering image of women as opposed to the degrading, discriminatory and sexualised representations of women in many Afro-Antillean literatures. In his Motivos de son, Guillén finally finds the purpose and objective of his poetry: to study the people and interpret their joys and pains in his poetry. Specifically, he captures, (re)presents and (re)interprets the "joys and pains" of women in Motivos de son in a constructive and broad-minded manner rather than following the more conservative and biased form of representation of women in Cuban society.

As demonstrated in this chapter, in spite of Guillén's deep anthropological knowledge of the composition of Cuba and of the prevalence of machista tendencies, I argue that he takes a bold initiative to deliberately deconstruct the dominant unproductive representations of women and reconstruct more assertive and progressive images of them. The zenith of this empowering and recreation of a more positive image of Black women is attained in the poem "Mujer nueva," where we witness the spectacular arrival of a different woman, a regal figure, a different kind of a Black woman from those in Motivos de son, to the New world with all possibilities in her possession.

From my analyses, I conclude that Guillén's representation of Black women has undergone a significant progression. The women represented in the Motivos de son collection of poems are depicted as real-life women and portrayed in their social settings - their day-today social environment and their relationships with the Black men around them-while in "Mujer nueva," we witness the prediction of the arrival of an ideal Black woman. Her arrival, it is to be appreciated, will bring a closure to all the negative stereotypes of Black women and usher in the charming, alluring and powerful "mujer nueva" who has the capacity to change her world. This objective is what I argue, the poems of Motivos de son collection and "Mujer nueva" have achieved — creating a more progressive image of Black women in Cuba in the 1920s and 1930s. 


\section{CHAPTER 5}

\section{INTRODUCTION AND HISTORICAL BACKGROUND TO THE STUDY ON ARMAH}

\subsection{Introduction}

In the preceding chapters of this thesis, we have discussed the early work of the national poet of Cuba, Nicolás Guillén, and his perspectives on issues of race, Blackness and the representation of women in 1920s and 1930s Cuba. After Cuba's independence in 1902, the Republic officially adopted the rhetoric of racelessness, that is, a position that avers that the ideology of racial divisions is non-existent in Cuba. However, Guillén, as we have argued, did not subscribe to this official position, believing — as we have seen — that in fact, society was divided along racial lines, discrimination against Blacks was rife, and the Cuban Constitution had failed to deliver on its promises of equal rights and privileges for both Blacks and Whites. Furthermore, Black women were misrepresented and devalued in this context. Guillén, as an engaged writer, we have argued, suggests remedial measures for the situation in his articles and his first works of poetry.

In the following three chapters, I will discuss the work of Ayi Kwei Armah, another engaged writer who sets out to address the issues that disappointed him in post-independence Ghana in his first work The Beautyful Ones Are Not Yet Born. He does not deal with the issue of Blackness or racism; rather, his focus is on the political culture of post-independence Ghana, and the non-progressive image and limited role of women within Ghanaian society. This chapter will present the history of Ghana that is relevant for this thesis, situate the work of Armah within this historical setting, and analyse the critical context within which Armah's work is situated. Chapter 6 will explore Armah's first book The Beautyful Ones Are Not Yet Born (1968) as a literary work that captures the Ghanaian writer's and the masses' 
disappointment at the decay and the corruption endemic in the post-independence society of Ghana. In addition, it will explore Armah's novel, as the work of an engaged writer and highlight the solutions that he proffers for the situation of Ghana. The final chapter will explore Armah's representation of Ghanaian women in post-independence society.

Ayi Kwei Armah was born on October 28, 1939 to Fante-speaking parents in the port city of Takoradi, Ghana. He attended Achimota School, the only school that was established by the colonialists at the time for the training of citizens to be employed in the service of the colonial government. Like many young and brilliant Ghanaians at the time, Armah left Ghana in 1959 to study in the United States, attending the Groton School in Groton, Massachusetts and went on to attend Harvard University. He wrote his first novel, The Beautyful Ones Are Not Yet Born, in 1968 after returning from the United States.

Armah's other novels include Fragments (1970), Why Are We So Blest? (1972), Two Thousand Seasons (1973), The Healers (1978), Osiris Rising: A Novel of Africa Past, Present, and Future (1995) and KMT, In The House of Life (2002). He has also written a number of critical essays, including amongst others "Fanon: The Awakener" (1969), "A Mystification: African Independence Revalued" (1984), "Masks and Marx, The Marxist Ethos vis-à-vis African Revolutionary: Theory and Praxis" (1984), "The Lazy School of Criticism" (1985), and “One Writer's Education” (1986). These works deal with varied themes; from problems of post-colonial Ghana to social and political ones, especially themes that have to do with consciousness-raising among Ghanaians and the larger African society.

Ayi Kwei Armah's The Beautyful Ones Are Not Yet Born (1968), the subject of these next chapters, I argue, adduces certain notions of Ghanaian identity as a solution for regeneration and reconstruction of a just socio-cultural milieu in post-independence Ghanaian society. These notions are mainly exemplified in the character of "The Man," (the protagonist of the novel). Although the birth of the "beautiful ones"- the ideal citizens that Armah hopes 
will be created - in post-independence Ghana fails to materialise in the novel, Armah brings a fresh approach to notions of national identity explored in Chapter 6 which are invaluable in the attainment of regeneration and regrowth, and to revised gender roles (Chapter 7).

Even though one cannot overlook the overwhelmingly negative images in Armah's work, I suggest that it is important to resist the temptation to read the novel as exclusively comprised of visions of despair, decay and decadence. ${ }^{39}$ Rather, I will argue that one must look beyond this imagery by examining the author's intention in pointing out the decay. As will be shown in the next chapter of this thesis, Armah's novel suggests ways of changing the bleak and decaying moral fibre of his society to a better, more productive one. He refers to this intention in The Eloquence of the Scribes: A Memoir on the Sources and Resources of African Literature (2006), stating: "I would like to use whatever skills I have, not for the maintenance of the existing world order, but for the creation of a better one" (12).

The Beautyful Ones Are Not Yet Born (1968) is set against the background of the political and social events that characterised the newly independent nation of Ghana. The novel's themes are varied, ranging from socio-political issues such as bribery and corruption, political campaigns, and false promises, to social alienation. The Beautyful Ones recounts the day-to-day life of a rail office worker, simply called The Man, over a series of days and follows his thoughts. ${ }^{40} \mathrm{He}$ endures insults from his family and fellow workers but resists the pressure and the temptation to accept bribes and to take part in the corrupt practices of the time. The purpose behind these corrupt practices is the acquisition of material goods. Those workers who accept bribes are able to live a relatively normal life, while, because of The Man's refusal to accept bribes (depicted in one episode in the novel), he and his family live from payday to payday, struggling to make ends meet. His inability to provide his family

\footnotetext{
${ }^{39}$ See Charles Nnolim (1979), John Lutz (2003) and many others who have considered Armah's work in this light.

${ }^{40}$ The name of this character is maintained in lower case (the man) in the novel, but in this thesis, because of the role he plays as the key protagonist around whom this work revolves, and for ease of recognition, the two words will be capitalised (The Man). This will be the case for the character of 'the teacher' too.
} 
with the latest commodities and luxuries leads him perceive himself at times to be a moral failure. His wife, Oyo, in spite of her dedication to the welfare of the family and her affection for her husband, frequently scolds him for not involving himself in the pursuit of material goods and wealth. Other characters in the novel include The Teacher, who acts as The Man's good friend and advisor, with whom The Man sometimes shares his frustrations about family life and the issues of life in general. Another prominent character is Koomson, The Man's former classmate. He was a dockworker before joining the socialist party to become a Minister Plenipotentiary and a member of the Presidential Commission for the Ghanaian government. He is married to Estella, a woman greedy for foreign and exotic goods. Other friends of The Man who appear in the novel are Etse, Maanan and Kofi Billy-his nonfamily social group.

The novel chronicles the state of despair and disillusionment in Ghanaian society after independence when new leaders were sworn into power. The frustration of the people stems from the fact that the new leaders, according to Armah, were the "sons of the nation" who took over power and then committed many acts of corruption and greed. The rampant nature of corruption in the society is evident in every economic dealing, where bribery and falsification of facts are the order of the day: "[T]hese were the socialists of Africa, fat, perfumed, soft with the ancestral softness of chiefs who had sold their people and are celestially happy with the fruits of the trade" (Beautyful Ones 153-54). The trickle-down effect of this social menace is seen at all levels of society in the novel.

The action of the novel takes place in post-independent Ghana, between a Passion Week $^{41}$ in 1965 and February 25, 1966 - just after the day, Dr Kwame Nkrumah, the first president of Ghana, was overthrown. The daily routine of The Man is portrayed in the novel starting with his journey by bus to the railway station where he acts as a traffic control clerk.

\footnotetext{
${ }^{41}$ The period referred to as Passion Week in the novel is a period of two to three weeks after payment of workers' monthly salaries. The pain and the agony of waiting for the next payment is described as a "passion week."
} 
The description of his routine is interspersed at every turn with visions of decay, excrement and filth, and repeated narrative descriptions of a nauseating and decaying environment. The dialogues, descriptions and word choices contribute to a sense of revulsion and disillusionment, which is lightened by only a very few rays of hope and expectation, as I will discuss in the following chapter. The narrative tone suggests Armah's pity and admiration for the protagonist, while also conveying an ironic and condescending attitude towards the "sons of the nation" who benefit from their corrupt practices. The narrative voice is an omniscient third-person narrator, which frequently focusses on The Man's internal reflections and observations. The diction moves from formal to informal, the sentence structures are both simple and complex, and the syntax is both grammatical and ungrammatical depending on the character being portrayed. Armah's use of language is both abstract (in the reflections of the characters) and concrete (in the description of the physical environment). The author's imagery ranges from visual, aural, olfactory, and tactile to gustatory. All this is presented to show the dynamism and multi-faceted nature of the first work of Armah.

This chapter is divided into three sections. In Section 1: The Historical Background, I give an overview of the situation of pre and post-colonial Ghana, which the novel captures and reimagines. In Section 2, I examine the representation of this historical situation in the novel at four levels namely: the national, local and family levels, in addition to the personal level of The Man. In Section 3, I look at the critical reception of the novel to show how critics have responded to The Beautyful Ones Are Not Yet Born, reactions ranging from outright dismissal of the work to support for Armah's perceived pessimistic view of the postcolonial society of Ghana. 


\subsection{Historical Background}

Armah follows other African writers (Sembène Ousmane, God's Bits of Wood [1960] [Les bouts de bois de Dieu], Wole Soyinka, A Dance of the Forests [1963], Chinua Achebe, No Longer At Ease [1960], and A Man of the People [1966]) in articulating a deep resentment towards the "failed" independence project in West Africa in the 1960s. Their resentments were particularly directed towards the tendency of new post-independence elites to replicate the rapacious behaviours of their former colonial masters. In Postcolonial African Writers: A Bio-bibliographical Critical Sourcebook (1998), Siga Fatima Parekh and Pushpa Naidu Jagne underscore the frank and uncompromising way many writers portrayed the situation of their countries after independence. They make specific reference to Soyinka's "uncompromising activism and outspokenness against neo-colonialism and corruption", an attitude that eventually led to his detention (440). In Armah's case, the depiction of Ghanaian postindependence society in his first novel, The Beautyful Ones, is an uncompromising intense representation, blunt and widely viewed as unpleasant.

The Beautyful Ones dramatises from a fictional perspective events from the recent history of Ghana. It represents proceedings at the first Prime Minister of Ghana, Dr Kwame Nkrumah's political rallies when he was seeking to be elected to power as President in the first general elections in Ghana in April 1960. The book also reproduces the last chaotic phase of his regime as President of Ghana, and ends with the coup d'état that overthrew him. The Beautyful Ones represents the period in Ghana in which corruption among both the elite and the ruling class has become prevalent.

In the era that the book depicts, corruption seems ubiquitous and persistent. The depth of corruption is seen in its institutionalised character: the act of giving a bribe or its acceptance is no longer a surprise to anyone, nor is it questioned by anyone. The work also highlights the consequences of the replacement of one corrupt elite-the colonial 
administrators - by another - the native Ghanaian elites. I claim that beyond the very obvious documentation of corruption and decay lies Armah's main purpose in the novel: an earnest desire to advocate for the regeneration and the regrowth of the nation of Ghana. In order to understand the background of the novel and its setting, an understanding of the relevant historical details of Ghana's journey to independence is necessary. This section outlines the history behind the achievement of independence and explores the factors that inspired the 1940s movement for independence in Ghana and the consequences of that independence process.

On March 6, 1957, after 113 years of British colonial rule, the people of the Gold Coast, a former British colony, obtained the right to self-government and the name "The Gold Coast" was changed to Ghana. Ghana became the first independent African country south of the Sahara. This was a historic moment for Ghana and for other African countries seeking independence.

The relationship between the European colonisers who came to the Gold Coast from the fifteenth century onwards and the people of the Gold Coast was complex and at times painful. When the first Europeans - the Portuguese - landed in the Gold Coast in 1471, it was to trade for gold and ivory. However, by the seventeenth century gold and ivory were no longer traded. Rather, slaves had become the object of trade due to high demand for cheap labour and raw materials in Europe at the time (Hargrove 33).

After the Portuguese came the Dutch, the Spanish and the English, all of whom constructed forts along the coast (Osborne and Kent 13). Ultimately, the British were the sole power remaining in the Gold Coast, buying up the forts and castles built by the Dutch when they left the Gold Coast (Johnston 177). Once they settled on the coast, Great Britain intervened in all spheres of life of the people of the Gold Coast, including building castle 
schools $^{42}$ and road networks. After the abolition of the slave trade in 1807, the British officially stopped trading in slaves in the Gold Coast (Earle 23, Greene 20-21) and began trading in commercial goods with most African nations along the coast. This trade was not beneficial to the African nations because most of the imports were British-manufactured goods and most of the locally owned companies were either dissolved or taken over by the British. For example, in 1821, the British government took over the ownership of the Gold Coast's private African Merchants Company. According to Kwame Appiah and Henry Louis Gates, in 1844, chiefs and elders of Fanti (a tribe mainly found along the coast of the Gold Coast) signed an agreement with the British that confirmed the colonial status of the coastal area (830). This bond was the first document that gave the British political authority and influence in the Gold Coast. The chiefs and people of the Fante tribe agreed to follow British law in return for British protection from the Ashantis (Kimble 194). ${ }^{43}$

Under colonial rule, the Gold Coast was administered through a system of "indirect rule." This system of administration allowed traditional rulers to govern their people under the direction and control of British officials. The traditional rulers who were designated as chiefs played a major role as intermediaries between the British administration in Ghana and the local people. This arrangement was clearly an illusion that disguised British rule. As Basil Davidson explains, "Britain's governor had enjoyed powers that were practically without limit" (Davidson 100).

The Gold Coast's determined efforts to seek self-governance were fuelled by many events and factors. From the time the peace bond was signed in 1844, resistance to

\footnotetext{
42 Accordiing to history, formal Western-style education in the Gold Coast actually began with the establishment of the "Castle Schools" by European merchants. As Owusu-Ansah indicates, "the best known of these programmes included the Dutch school at the former Portuguese fortress at Elmina, the English at Cape Coast Castle and the Danish at Christianborg Castle" (128). He futher observes that few children of wealthy Africans and local chiefs received instruction at the Castle Schools; rather, as historian C.K. Graham, quoted by Owusu-Ansah notes, "the majority of students attending the European-run schools were mulatto children of the European castle staff and their African women" (Owusu-Ansah 128).

${ }^{43}$ The Ashantis (mainly found in the central part of the country) waged war against other tribes and fought a series of wars against the British who sought to protect their commercial interests in the Gold Coast. The British won the campaign and finally forced the Ashantis to accept a treaty signed on July 24, 1874.
} 
colonisation in the Gold Coast, which mainly had its roots in the elite class, was largely invisible. Most of its manifestations were in the form of the establishment of groups like the Fante Confederation in 1868 (Agbodeka 1, Nti 4), the Aborigines' Rights Protection Society (ARPS) in 1897, the National Congress of British West Africa (NCBW) in 1920 by Casely Hayford and the Gold Coast Youth Conference (GCYC) that was founded by J.B. Danquah in 1930. In one of its achievements in 1897, the Aborigines' Rights Protection Society successfully blocked a bill that would have made all physically unoccupied territory in the colony the property of the colonial administration (Briggs 23). The GCYC in 1934 sent a delegation to London to ask for constitutional changes to the advantage of the Gold coast communities (Davidson 75). The NCBW for its part, through a detailed document, attempted to secure equal job opportunities for Africans and Europeans with equivalent qualifications, suggested the election of members of the legislative council without interference from the colonial government, and sought to allow for a transparent selection and removal of chiefs, but did not succeed. When the delegation sent the document that contained these proposed amendments to London, they were refused an appointment with the Colonial Secretary (Briggs 23). The formation of these trade groups and civil rights movements was geared towards putting in place structures that would help begin Ghana's journey towards independence.

After a relatively stable period of colonial administration, vehement reactions to colonial rule began to emerge from all sectors of society, mainly caused by the fact that after the initial agreement of indirect rule, there were no benefits accruing to the colonies from the arrangement. The British Empire maintained the colonies for its own benefit; the Gold Coast became a source of raw materials, as well as a market for industrialised goods exported from Britain. Worse, the British reserved the power to manipulate prices of raw materials that were produced in the Gold Coast because there were no industries there to process and add value to 
the raw materials before export (Hargrove 33). These price manipulations were obvious to the local people and, in this manner, the colonised indirectly learned from the colonialist how the administrative system could be exploited for the benefit of some individuals and not for the improvement of the lives of the masses.

The educated elite were unhappy about these events in the country. Chiefs resisted the weakening of their authority and protested against the British, and this eventually led to the deportation of some of them. For example, King Aggrey of Cape Coast was deported to Sierra Leone in 1866 when he criticised the British (Nti 3). Besides the traditional leaders and the educated elite, ordinary people like railway workers and farmers also played a role in the nationalist struggle. There were the famous cocoa hold-ups of the 1930s to protest the "monopoly of the Great Combines"-a combination of Lever Companies globally represented by the United Africa Company-and other multinational companies like Compagnie Française de l'Afrique Occidentale (CFAO) and Sociéte Commercial de l'Ouest Africain (SCOA) who had the sole responsibility for marketing the cocoa product around the world (Cunard 168).

Another important issue of concern for the local people was education. Even though there were schools located in the slave forts, or Castle schools, their curriculum was geared towards the goal of clerical literacy for the people of the Gold Coast and the curriculum served the needs of the British colonial masters. Most of the citizenry educated there were trained in clerical skills to fill roles such as stenographer secretaries, administrative assistants or special assistants to the colonial administrators (Amamoo, "New Ghana" 10-11) rather than trained for higher level employment, such as architects, engineers or doctors. These clerical jobs were considered to be for low-level staff and mainly had low-level incomes and were only accessible for very limited numbers of Ghanaians, mostly male. Joseph Amamoo, for instance, affirms the inadequacy, and indeed, irrelevance of the education system in the 
Gold Coast by giving the percentage of the population of Ghanaians who were illiterate at the time of independence in 1957 to be about 80\% (15).

There were other issues of discontent in the Gold Coast. Such concerns included the maltreatment of soldiers who returned from the World War II, the lack of freedom and democracy in the Gold Coast, and the low producer prices for cocoa. In 1946 when the troops were demobilised and returned home, they found to their astonishment that the pension, gratuity and jobs that they were promised on their return from the war in Burma and India were a deception. ${ }^{44}$ Their situation was difficult because many of them could not find work; they were discriminated against and, above all, they were no longer ready to go back to their old ways of life, full of poverty (Briggs 3, Hadjor 41-42, Hunter 159).

Another issue that caused discontent among the ex-servicemen was the fact that the freedom and democracy that they believed they had fought for during the war, was not present in their own country. They did not consider themselves "inferior" to the colonial masters any longer since during the war, they fought alongside each other, without experiencing issues of race or status. With these interactions, the ex-servicemen gained confidence in their own abilities. Hadjor argues that "the experience was crucial in opening their eyes to the ways of the world. Mixing with other Africans and with Asians, they could see that throughout the Third World, there was a common yearning for freedom" (41-42). This also made them question their own circumstances of living under foreign rule at home.

Ghanaian farmers all over the country did not get a sufficient return for their produce, as the producer prices of most crops on the world market were very low. Cocoa farmers were greatly affected by plummeting prices. In addition, some cocoa plantations were affected by

\footnotetext{
${ }^{44}$ This is one of the issues that Armah deals with in his first work. He expresses the disgust for the deplorable situation of the returnees and the disillusionment they expressed towards those close to them, especially their immediate families. See Armah, The Beautyful Ones, 75.
} 
widespread swollen shoot disease ${ }^{45}$ and the colonial government did not provide sprays for the crops but rather insisted that all the trees be cut down, thus provoking the resentment of the farmers (Bourret 168).

These issues exacerbated economic differences in the standards of living between the elite few and their British counterparts on the one hand, and the rest of the local population on the other, creating a deeper rift between the colonial elite and the ordinary citizens. The consequence of these gaps manifested in the form of difficult socio-economic choices that these citizens had to make each day - many survived on credit, and many more remained in debt payday after payday, leading to further discontent. At this point in the history of the Gold Coast, the extent of economic hardship was unbearable and the urge to change the political system and its rulers became overwhelming. New leaders were needed, ones who could help the nation fight for independence and who understood how the system of colonisation works. How these leaders emerged is discussed below.

During the first half of the twentieth century, the Gold Coast was experiencing class stratification with most of the African business executives and merchants belonging to the elite class. These elite people sent their children overseas for higher education as there were no institutions of higher learning in the colony at the time and they could afford the cost involved. This opportunity to study abroad exposed most of these young people to issues of the world at the time. For example, they learned about some of the most important events in Western history such as the French and the Russian Revolutions, and the two World Wars, as well as the main philosophies and ideas of the century. This body of ideas changed their

\footnotetext{
${ }^{45}$ This is a disease of the cocoa tree, caused by the cacao swollen shoot virus (CSSV). It is one of the major disease problems that affected cocoa production in West Africa, most especially, Ghana, Cote d'Ivoire, Nigeria and Togo. See Dzahini-Obiatey et al., "Over Seventy Years of a Viral Disease of Cocoa in Ghana: From Researchers' Perspective," 476-85, and Thresh et al., "Ghanaian Cocoa Varieties and Swollen Shoot Viruses," $219-31$.
} 
worldview. Upon their return to Ghana, many of them took up positions as lawyers and journalists, and with these backgrounds, they expressed their disgust about colonialism and mustered resistance towards it. It was not surprising that in 1947, a group of these elite lawyers and journalists formed the first political party in the Gold Coast, the United Gold Coast Convention (UGCC) and began the final struggle for independence (Davidson 53).

Kwame Nkrumah, who was in the United States at the time, was invited by the leaders of the UGCC to be the General Secretary of the party and to help mobilise its support base since he had a wealth of experience in the organisation and rallying of the masses (Davidson 53). The UGCC leaders saw rallying the masses as a crucial part of their struggle for independence, even though the elite was at the forefront (Zeilig 78). However, shortly after Nkrumah's return to Ghana in 1947, he fell out with the executive members of the UGCC who were working with the slogan "Self-government within the shortest possible time," while Nkrumah wanted "Self-government now." Consequently, Nkrumah broke away from the UGCC and founded his own party, The Convention Peoples Party (CPP) in June 1949. From January 1950 onwards, Nkrumah organised nonviolent protests and strikes in the country, which the colonial administrators saw as undermining their authority and therefore sent him to jail (Davidson 76). The author of The Beautyful Ones recalls, as a young man who was then about to enter secondary school, how Nkrumah was arrested and handcuffed: "The man in handcuffs (Nkrumah) had left the Gold Coast in his youth to study in America. He had come back saying it was time Africans ruled Africa, and used African resources not to enrich European corporations and African stooges but to create prosperity and meaningful work for Africans, in Africa" (Armah "Eloquence" 16). Nkrumah was still in jail during the 1951 general elections but his party won the elections, taking 35 out of 38 seats and, when the colonial administrators saw the overwhelming support for his party, he was consequently released from prison to become the Prime Minister and to form a new government. After 
winning the next two elections in 1954 and in 1956, the CPP was ready to demand independence from Britain in 1957 (Biney 75).

Even though Nkrumah was elected as Prime Minister in 1952, the colonial administrators were still occupying very important administrative positions. Davidson describes the experience of Nkrumah and his ministers thus: "He (Nkrumah) was to form a CPP government in a country still under stiff colonial rule. He and his African ministerial colleagues were to have no power in vital questions of foreign policy, national defence, internal security ... not even to have any power over appointments in the civil service" (Davidson 87). Worse, they did not control government finances. Nkrumah's remark upon taking office underscores the state of things: "[M]aking our tour through room after room, we were struck by the general emptiness. Except for an occasional piece of furniture, there was absolutely nothing to indicate that only a few days before people had lived and worked there" (quoted in Davidson 94).

On 6 March 1957, Ghana attained independent status, with Kwame Nkrumah making his famous "motion of destiny" speech, declaring that "Ghana our beloved country is free forever!" and linking the independence of Ghana to that of the total liberation of the African continent (Biney 53, Hadjor 19, Zuberi 65). After independence, Nkrumah implemented policies to foster the rapid growth and development of the nation. According to Amamoo, "impressive achievements were chalked up, especially in the fields of education. Hundreds of secondary schools were opened and elementary schools started in the villages which previously had never seen any" (“Ghanaian” 15). The CPP government resolved labour shortage issues by expanding educational infrastructure and introducing free education in some areas (Okyere 176). The economic sector underwent rapid growth through state-led initiatives or private-state partnerships. Later, a dam was built to generate electricity (Biney $58)$. 
However, the Akosombo Dam project on the Volta River put the country into huge debt. Nkrumah's government had to finance the debts by raising taxes on cocoa and other products (Davidson 176). The building of the dam also caused the displacement and relocation of some 80,000 people. These issues increased tension between Nkrumah and the influential farmers in the administrative regions of Ghana. Critical and cultural debates and the arts were stifled, and no one dared to criticise Nkrumah. As expected, opposition to Nkrumah's government grew and many people decried his lack of focus, accusing him of not spending enough time thinking about the nation but rather "spending too much time building networks and connections abroad" (Davidson 176).

During this process, Nkrumah also lost touch with the ordinary Ghanaian citizens who had voted for him, and made decisions and pronouncements that lost him their support. In one such pronouncement, he declared that "party members should own no more than two houses" when the majority of the population could not even afford to own one (Davidson 177). Amamoo describes the "looting" of the national purse thus: "[L]ong before the coup of February 1966 ..., it was well-known that a number of ministers and prominent party officials, who previously were people of modest means at best or sometimes, of rather limited means, had suddenly become very affluent” (“Ghanaian” 33). The Akainyah Commission Report of 1964 confirmed the endemic nature of corruption in Nkrumah's government stating that "it is unfortunate and pathetic that the love of money has become an obsession with some of us, and drives us to any length to get rich quick without stopping to think of the consequences. So long as we can get the money, we do not care whether or not our country is plunged into bankruptcy" (Le Vine 25).

In two further decisions, Nkrumah approved an increase in taxes, and legislated the Preventive Detention Act, which was used to "detain no fewer than nineteen trade unionists" (Davidson 177). In 1964, in an attempt to curtail the powers of the judiciary, Nkrumah 
obtained a constitutional amendment that allowed him to dismiss any judge. He made the following statement after dismissing the Chief Justice of Ghana who had acquitted some people whom Nkrumah thought should be sentenced for treason: "[T]he judges of the special court by their failure to take me into their confidence meant to create discontent and terror throughout the nation. My duty is not only to govern but also to ease the conscience of the people by giving them peace of mind and tranquillity. A nation cannot tolerate a dishonest and corrupt judiciary" (quoted in Coleman and Rosberg 311). It was at this same time that Nkrumah passed a constitutional amendment through Parliament that made it possible for only one candidate to contest the presidential elections. This meant that Ghana officially became a single-party state in 1964. (Boafo-Arthur 126, Kasfir 231-32). After his party's overwhelming win in the 1965 parliamentary elections, Nkrumah proclaimed himself "President for life".

With increasing discontent and tension in the country, it did not come as a surprise when several attempts were made on Nkrumah's life: a coup plot by R.R Amponsah, M.K Apaloo and others in 1958; a railway bomb strike in 1961; the Kulungugu assassination attempt in 1962; and another assassination attempt by his own bodyguard, Seth Nicholas Ametewe, made in 1964. (Mwakikagile 46-48). Nkrumah became very suspicious of everyone and was also sceptical about the capacity of his bodyguards to protect him, and therefore requested Russian forces to protect him. Furthermore, he began to isolate himself from the public, and had opponents thrown into jail (Packman 173).

Nkrumah was initially supported by the masses because he identified with them in their hardship, but it is the same story in reverse that led to his unpopularity with the masses. Once he was in power, he failed to appreciate the degree of economic hardship that the masses were facing and this led to the plummeting of his popularity and to disaster for his government. On February 24, 1966, while in Peking, he was overthrown in a coup by the 
military (Davidson 203). According to Amamoo's account, a group of Army officers led by Colonel E.K Kotoka, Major A.A. Afrifa, Major V. Coker-Appiah and Brigadier A.C. Ocran carried out the coup. In collaboration with the Ghana Police, they arrested "all cabinet Ministers, top party functionaries and officials, all regional commissioners, district commissioners and party officials" ("Ghanaian" 43). The police were also aided by a battalion of troops from the Ashanti region and the northern part of the country, who, "on the pretext of conducting training manoeuvres in preparation for their dispatch to Rhodesia had reached Accra" (45) and took part in the coup. Some senior officers who were not happy with the coup were locked up and those who resisted arrest were shot. At about $5.30 \mathrm{am}$ on $25^{\text {th }}$ February 1966, Major Afrifa announced that Nkrumah was no longer president of Ghana, stating that the latter's government had encouraged "corruption, bribery, nepotism, economic mismanagement, moral depravity, oppression, tyranny, dictatorship ..." (46).

People poured onto the streets and demonstrated against Nkrumah and his ministers. Amamoo describes the protests: "While the arrests of the former ministers and party stalwarts were going on, the masses, who had previously poured on the streets to demonstrate for Nkrumah and pledge their unflinching loyalty to his regime, poured out again on the streets to demonstrate, this time against Nkrumah" (46 emphasis in original). This incident parallels what Armah describes at the end of his novel: "When the sun had gone up, there was the sound of some commotion in the street ... With a silence that spoke everybody's shame, the men in the office went out singly to join the crowd outside. In the same manner, they had gone out in fear to hear the farts of the Party men" (Beautyful Ones 186).

The predominant problems besetting the early years of independence for Ghana, then, can be seen as lack of vision and direction of leaders, bribery and corruption by the political elites and the disappointment of the masses about the inefficiencies of the new rulers of the 
country. Armah depicts these problems in his first novel, and sets out the implications of these problems at all levels of society, namely national, local, family and individual.

\subsection{Fictional Representation of Ghana's History in The Beautyful Ones.}

\subsubsection{At national level}

There are many national, historical, social and political issues commented on by the characters in the The Beautyful Ones. For example, the novel gives us a picture of the rise and fall of Kwame Nkrumah, picking up the story of the political rallies of Nkrumah before his incarceration. The narrator describes how Nkrumah convinces the masses to vote for him because, as one of the "veranda boys," 46 he shares the socio-economic conditions of the ordinary Ghanaian citizen as he says, "I have come to you. And you can see that I have nothing in my hands. A few of you here know where I live. Not much is there" (101). The point of view of the narrator and the overall structure of the novel and characters direct the reader to recognise important aspects of Ghana's experience. Armah illustrates the political campaign well in a scene where a man, only known as the 'new man' but who can be taken to be Nkrumah, addresses a political rally: "[A]lone, I am nothing. I have nothing. We have power. But we will never know it; we will never see it work. Unless we choose to come together to make it work. Let us come together... Let us.... We.... We.... Freedom.... Freeeeeeedom!" (102). The narrator then takes us forward to events after the campaign and elections where the elites, now in power, ignore the masses and perpetuate the corrupt practices of the colonialists. After convincing the masses in this way, and consequently winning their votes, his actions and inactions show a very different personality with a different vision and aspiration. The central character (The Man) explains the bitter experiences of those who believed what they were promised during the campaigns, which

\footnotetext{
${ }^{46}$ Veranda boys are party activists who are considered to have low social status.
} 
later was revealed as a deception: "He was good when he had to speak to us, and liked to be with us. When that ended, everything was gone. Now all we do is to sit and wait, like before he came". The cause of this, it is stated explicitly, is the corrupting influence of power: "It must be power. I say this because he is not the only one whom power has lost. It happened to those around him ..." (103).

In the novel, on the arrival of "the new man" to address a political rally, the narrator takes readers back to other rallies that have been organised in the past and explains how these end up frustrating and discouraging the populace. Their displeasure is either because those who address the rally say the same old things again, or because the gathering has had to wait several hours before they show up to address them. The character of Etse captures the cycle of hope and disillusionment in the following remarks. ${ }^{47}$ He describes the man addressing the rally as "just like the others, talking to men without jobs about work" they have to do. After listening to the man for a while, Etse remarks that it is "better to go home and not go standing in the sun ..., and to let the clowns talk to each other and the white men they love with fire" (99). However, later, the attitude and reaction of the characters change when they encounter a new situation: a man simply called the "new man" addresses the rally saying, "we do not serve ourselves if we remain like insects, fascinated by the white people's power. Let us look inward. What are we? What have we? Can we work for ourselves?" (101).

The central figure, The Man, recalls first hearing the "new man", acknowledging both his scepticism and the persuasiveness of this new orator. So powerful is the new man's speech that he has to overcome a sense of shame at being swept away emotionally by this rhetoric (101). He does not report the whole of the speech but captures both its tone and effect on the crowd. However, he immediately weaves into this account his awareness of how

\footnotetext{
${ }^{47}$ It is also worth noting that Etse is a kind like the English courtly figure of "the fool" (that is, a kind of clown himself) who uses mimicry to draw attention to the folly of his "superiors".
} 
it ends - how the promise is corrupted — so that the happiness and brief optimism he records feeling in the moment is immediately set against the disappointment with which he views things later: "The promise was so beautiful. Even those who were too young to understand it all knew that at last something good was being born. It was there. We were not deceived about that. How could such a thing turn so completely into this other thing?" (Beautyful Ones $100)$.

As already explained, at independence, the nation of Ghana had great potential to produce primary products such as cocoa and timber in large quantities for export. This potential was however, not realised because of the self-seeking interests of the elite and those in power (Jedwab and Osei 6-8). In the fictional world of Armah's The Beautyful Ones, this potential is hinted at when The Teacher asserts that "we were ready for big and beautiful things" (94). Armah makes it clear in the novel that these big and beautiful things could not be accomplished because of the vested interests of the elite, whom Etse describes as "clowns" (99). An example is seen in the scene where he describes a new politician as "a new lawyer, wanting to be white, ... He is another fool, then" (98-99). Self-serving elites dissipate the country's considerable potential, depicted in the novel in the lifestyles of Koomson and other ministers and elite lawyers living at the Esikafo Aba Estates and the Upper Residential Area. As already stated, when the masses' discontent with the corrupt and self-serving leaders became overwhelming, they revolted and with the help of the generals staged a coup d'état, depicted at the end of the novel. They demonstrated their loyalty to the new leaders with songs that replaced the old lyrics of praise for Nkrumah with insults: [T]hrough the windows their sounds came: old songs with the words changed from the old praise for Nkrumah to insults for him" (186). 


\subsubsection{At local level}

The implications of the high-level corruption of the elites have effects at the local level. Most people at the local level find out, belatedly, that the only way one can survive in Ghana at this time is by creating networks and alliances with the elites at the national level. In this way, the corruption of individuals and its attendant enrichment of private pockets at the expense of the nation and the masses continues at the local level. In a sense, everybody is corrupt in his own field of work: from the bus conductor we see at the beginning of the novel, all the way up to ministers like Koomson. Corruption has become the generally accepted state of affairs, where by refusing a "gift" a person is perceived as awkward, cowardly, foolish, criminal and even perverse. As the narrator states: "[E]veryone will tell you, pointing, that only the impotent refuse. Only those who are too weak to possess see anything wrong with the possessing fashion. Better get it all first, then if you still want to condemn, go ahead" (106). When The Man's wife finds out that he has refused a bribe, she calls him "an On-ward Chris-tian Sooooooldier" (51), implying he is behaving as the only "good" person in the society. He himself feels "like a criminal" $(63,69)$, and "a helpless combination" of coward and fool (59).

In the novel, the giving and accepting of bribes is an integral part of low-level administrative and local authority jobs, such as The Man's Control Room job. Many characters in the novel see bribery as part of getting the job done, as in the following two examples. In the first, an office clerk suggests that for one's winnings in the lottery to be paid, one has to bribe an official with part of the winnings: "I hope some official at the lottery place will take some of my hundred cedis as a bribe and allow me to have the rest" (21-22). When the narrator points out that this is corruption, the clerk replies: "This is Ghana" (2122). In a later instance, which I will discuss in greater detail in the next section, a timber merchant suggests that people occupy positions of authority in order to enrich themselves: 
"[B]ut you also know that everybody prospers from the work he does, no? Everybody prospers from the job he does" (37-38). In these two examples, the novel shows the general acceptance of corruption. As such, the local community, represented in the novel by the clerk, The Man's mother-in law and The Man's friend Koomson, reflects these corrupt practices and attitudes.

Armah shows how difficult it is for The Man to negotiate his daily activities and at the same time remain morally upright as he navigates his local community, particularly in "the gloomy building of the Post Office," the dirty alleys and the banister which will convert all the dirt into "victorious filth" and all "around decaying things push inward and mix all the body's juices with the taste of rot" $(8-9,11,47)$.

Armah's novel generally positions the reader to understand that these attitudes are deep-rooted in the socio-cultural fibre of the local community and have become a way of life. It appears from the novel that the ease with which one could gain access to these riches makes it irresistible. In addition to this, we see the mystical charm that the glitter of these riches, which Armah calls "the gleam", adds to the lives of these individuals. He describes the properties of the gleam as "having the whiteness of stolen bungalows and the shine of stolen cars" (111). Eventually, he thinks aloud to himself that maybe "the gleam of all this property would have the power to make us work harder" (111), but that is not the situation in the novel since these items were stolen and not earned. Moreover, the self-seeking interests of people at the local level, for example, the allocation clerk in the Man's office, who takes the bribe that the Man has refused, makes it impossible to ensure the issue of corruption is addressed, hence their downfall at the end of the novel. An example of the disgrace suffered by these people is Koomson who must flee from the demonstrating public because "he fears they will kill him" (189), hiding in a filthy latrine, going in "head first" (197). This act is both a punishment and a metaphor for his sin of corruption. 


\subsubsection{At family level}

In this environment where bribery has become commonplace, The Man's family develops a distorted view of his values. Most people at the family level are able to purchase material goods either because of corruption or continuous borrowing of money for basic needs. The Man's inability to fulfil the material desires of his wife Oyo and his mother-in-law leads to his alienation from his family. While from another point of view, his refusal to engage in bribery might seem heroic and virtuous, his family members only recognise the ways in which his refusal costs them in material terms and he is aware of this. He meditates on one such moment: "How much hard work before a month's pay would last till the end of the month .... And food. How long would it take, and how hard the work, before there would be enough food for five, and something left over for chasing after the gleam?" (112). He concludes: "[W]hat would be the point, when so much pain was shooting out toward the beloved, ..., what would be the point, especially since these days outside the area of the gleam, which made the loved ones suffer in their impatience, there was nothing worth pursuing" (54). The Man's family read his honesty and integrity in terms of a failure of care and responsibility, not in terms of its ethical strength. The Man's friend, the Teacher, is also alienated from his family because of their demands that he was unable to meet. To the Teacher, the embrace of his loved ones "will be a welcome unto death" and so he flees from them into self-imposed isolation (65).

The temptations of material goods, or what Armah calls "the gleam," look attractive and the smaller family unit is unable to resist this attraction. Those in the family unit who are attracted to the corrupt practices and cannot resist the allure of its attraction tend to be in constant struggles with their family members if they do not agree to pursue the "gleam". Thus, the corruption of the larger society can be seen as impeding the smooth functioning of the smaller family unit. Armah invites us to see the causal relationship between the highest 
level of society and the family unit. Because of this, difficulties emerge in the sustenance of an integrated family. In other words, the effectiveness or otherwise of the lower-level of society depends greatly on what happens with the higher-level society, or the national level. The Man's wife yearns for Estella's perfumes and her chauffeured-driven experiences, but since she cannot have these because of her husband's refusal to accept bribes, she calls him a chichidodo. ${ }^{48}$ The Man's mother-in-law disrespects him because he does not take what she considers to be "good" care of her daughter and he is not ready to sign a fraudulent boat contract, which she sees as a way out of their poverty (164).

The extravagant lifestyle of Koomson and his wife is also highlighted. Koomson "robs" the state through corruption and the novel gives an example of this lifestyle when The Man and his family encounter the Koomsons. In the first scene when The Man and Oyo host the Koomsons, Estella complains about the quality of the drinks that The Man serves them: "[Y]ou should have bought European drinks, and not have wasted your money like this". Even though Koomson says the quality does not matter, the wife insists, "Really, the only good drinks are European drinks" (155), displaying considerable snobbery. Later, the description of the Koomsons' house and the admiration that it draws from The Man and Oyo encapsulates the extravagance: "[T]he two, left alone, were at first too busy taking in the sight of the room they were in to say anything to each other ... There were things here for a human being to spend a lifetime desiring. There were things here to attract the beholding eye and make it accept the power of their owner" (170). They saw items such as "new television sets," "glass covered shelves," "polished dishes," "intricately designed ashtrays," things that were impossible to overlook (170).

\footnotetext{
${ }^{48}$ In the Beautyful Ones, a chichidodo is explained as a bird, which likes worms but does not like the sight of excrement. The Man's wife uses it here to describe her husband as someone who likes good things but does not want to involve himself in the only way to get them-through bribery and corruption (52).
} 


\subsubsection{The Man (at the level of the individual)}

The central protagonist of the novel is the unnamed man, an Everyman character. He is intelligent, self-reflexive and does not judge other people. Despite all the corruption, filth and decay that surrounds him, The Man holds fast to his integrity, which I will argue, is part and parcel of his traditional Ghanaian values. The novel does not demonstrate to us that these values are simple. Armah does not make it pleasant for The Man to hold to these characteristics. Nor does he openly affirm the character of The Man.

Critics such as Chidi Amuta (1981) and Derek Wright (1986) among others, argue that Armah's vision is negative because he does not create a strong character who overcomes the corruption and the decay of Ghanaian society in the novel. However, Armah's response is right there in the novel-in the character of The Man who never succumbs to the temptation of corruption. Most critics have failed to recognise the solution they are seeking is present in the daily decisions of The Man. Armah does not suggest any easy path to the achievement of these values which nevertheless are necessary. As a pragmatist, Armah understands that it will take a long time for "the beautyful ones" of the future to materialise.

The Man does not become rich at the end of the novel nor does he change his socioeconomic situation. There is no indication that he triumphs over all the obstacles that he is confronted with in the novel. Clearly, Armah's characterisation in the Beautyful Ones emphasises the fact that regeneration and regrowth is a long-term project, and it takes steadfastness to get to the end - as can be seen in the encounters The Man has in the novel.

The section above has discussed the trend of corruption found at various levels of Ghanaian post-independence society as described in The Beautyful Ones. It also emphasises the effect of corruption found at these levels. In the next section, I will examine the critical reception of Armah's novel, demonstrating that most of the critics have read Armah's first book as a profoundly negative portrayal of Ghanaian society. I will argue against these 
negative and unproductive readings of The Beautyful Ones, asserting that Armah does offer a ray of hope for the society described in his novel.

\subsection{Locating The Beautyful Ones in its Critical Context}

It is commonly believed that the idea of corruption and disillusionment is central to Armah's intentions and aspirations expressed in the novel. This belief has persistently drawn critics to evaluate this work mainly on its predominant and powerful imagery of rot and decay. They contend that Armah's depiction of corruption of all kinds does not provide an accompanying "strategy" of escape from this canker. Ama Ata Aidoo and Chinua Achebe share this perception of the work as merely an expression of doom. In an introduction to the CollierMacmillan edition of the novel in 1969, Ama Ata Aidoo, in the spirit of "patriotism" observes in her introduction to Armah's work that Armah consciously portrays the negative by leaving out "whatever is beautiful and genuinely pleasing in Ghana". As it stands, she argues, Ghanaians "could find it difficult to accept in physical terms the necessity for hammering on every page the shit and stink from people and the environment" (xii). Aidoo acknowledges Armah's commitment to explaining the socio-economic disillusionment that permeates the post-colonial Ghanaian society. However, Armah's disservice to society is, according to Aidoo, his inability to provide a glimmer of hope in his work or to depict what is pleasant.

Achebe, on the other hand, in Africa and her Writers describes the book in very distasteful language. He describes The Beautyful Ones, as "a sick book. Sick, not with the sickness of Ghana but with the sickness of the human condition" (24), rather than focussing on Ghana itself. He criticises Armah for adopting a Euro-centric view in his work through his depiction of "the human condition" and suggests that Armah is "in grave danger of 
squandering his enormous talents and energy in pursuit of the human condition" (24). His dislike for Armah's work stems from what he describes as Armah's "foreign" themes and stylistics. He insists that not only does the book fail to address any "beautiful" thing in Ghana, but in it "Armah imposes so much foreign metaphor on the sickness of Ghana that it ceases to be true" (24-26). Achebe does not criticise Armah's work in the light of any special concern he has but solely on the fact that Armah writes about the condition of Ghana "like some white District Officer" (26). Described in this manner, Armah and his work could be evaluated as an extension of the colonial past. As I will demonstrate later, Achebe's negative views about Armah's work are rather at variance with this thesis.

Another critic who describes Armah as a pessimist who in his work only interprets the world around him as full of evil is Charles Nnolim. He alludes to Armah's vision of corruption and decay as inescapable and occurring both in society and in nature. By attributing "a naturally occurring" characteristic to Armah's work, Nnolim asserts that, for Armah, these conditions are inevitable and unchangeable. He describes Armah as "a writer whose philosophic pessimism is undisguised in each work... [He] is both a cosmic pessimist (who views the world as inevitably and intrinsically bad and life in it as essentially gloomy and futile), and a retrogressive pessimist or pejorist (one who views the world as undergoing an inevitable corruption and degeneration" (207 emphasis in original). Furthermore, he insists that Armah has a penchant for the absurd and the decaying, almost as a fetishist, "who seems to be unusually excited by images of decay and corruption", and who "never fails to focus on the wetness that accompanies corruption and decay (to everyone's disgust). Hence, the preponderant images of ooze, clamminess, slime, lubricity, mucus, urine, with their accompanying offensive smells, often made more disgusting with the images of retching, farting, vomiting, and bad breath" (207). Nnolim does not see any possibility of regeneration in Armah's work—rather a Swiftian vision of disgust and the grotesque. 
In his critical essay of 1979, Leonard Kibera does not consider The Beautyful Ones as providing any solution to the socio-economic reality of Ghana; rather, he judges it to be a mere work of art that does not go beyond the surface of issues at stake. He suggests that The Beautyful Ones is "not part of that literature which probes below the obvious at critical moments of history ... but rather the unyielding statement that the world remains static, unfeeling, and that the hopes of the early sixties have given way to pessimism and death" (64). In Kibera's estimation, Armah is expected not only to expose the failings of the political experience but also to provide some solution. He indicates that "in castigating us, the writer should not be shy of possibilities even though in the end he may find none" (71). It is clear then that Kibera also fails to see any possibility of regeneration in Armah's work.

Notwithstanding the position of the critics mentioned above who have categorised Armah's work in a negative way as "essentially" pessimistic, there are several others who have applauded this pessimism. That is, they have accepted Armah's clear-sightedness in portraying post-independence Ghanaian society so negatively. For example, Neil Lazarus, Ojong Ayuk, Akaeke Onwueme, and Derek Wright among others have defended Armah's decision to dig deep into the political and cultural fibre of society and highlight the ills but they too are unable to see any positivity on regenerative possibilities in The Beautyful Ones.

Even though Neil Lazarus had earlier in an article "Return" described Armah's postcolonial writings as being "for all their militancy, among the bleakest and most disenabling texts to be produced during the first decade of independence in Africa" (14), he was to later change his opinion. In his Resistance in Postcolonial African Fiction (1990), he argues that Armah's first novel "is formulated upon the premise that it is only by knowing one's world, by seeing it for what it is, that one can ever genuinely aspire to bring about revolutionary transformation" (48). Interpreting the novel in this manner contests the conviction that in The Beautyful Ones Armah caused irreparable harm to Africa's 
revolutionary aspirations. Rather, for Lazarus, Armah's primary concern in this work is to depict society accurately with all its defects, as I have argued Guillén did in his work.

Ojong Ayuk argues that The Beautyful Ones is Armah's response to the decay in postindependence Ghana. He indicates that Armah's book conveys the feelings of all those who were deprived of the benefits of independence. In order to alleviate the pains of this deprived citizenry, Ojong Ayuk argues, Armah decides to "plumb the reasons for the decay of his society and to combat, through fiction, the factors which have inhibited revolutionary growth" (35). The idea of "plumbing" the decay of the society is very relevant to this thesis since this is what the thesis conceives as one of the main idea behind Armah's creative work in The Beautyful Ones.

Akaeke Onwueme has similarly defended Armah's work in terms of finding value in its pessimism. He explains that Armah's first novel has been subjected to "undignifying trial" (71). According to Onwueme, Armah's work is a sort of spiritual exercise that is performed on the soul of the main character and all the others in the novel. In Onwueme's evaluation, Armah's work has to take this form of a spiritual exercise in order to "exhume, excoriate, and churn out dirt" which will finally generate "a motion not just to produce a cathartic effect but to reveal 'the way' hidden beneath the depth of decay so as to unravel its beauty and open up new frontiers and vistas of hope" (75). Instead of imposing a negative reading on the novel, he would rather affirm that it somehow has a "healing mission and vision" (75). However, he does not make the nature of this healing explicit. Onwueme's position serves as a point of departure for this thesis which builds further on the "spiritual exercise" he alludes to, to specifically study the character of The Man as an icon for unravelling the "beauty" beneath the decay and opening up new frontiers and vistas of hope, as indicated earlier.

There is a similar effort to defend Armah against the various criticisms levelled against The Beautiful Ones by Derek Wright. In his 1985 article, “Armah's Ghana Revisited: 
History and Fiction," Wright seeks to defend some of these allegations including the lack of portrayal or rejection of the extended family system; lack of distinction between different kinds of Ghanaian speech; depiction of a falsified image of Ghana; and lack of deeper insight into Ghanaian issues because of Armah's outlook as an "exile". Wright asserts that most of these allegations are inaccurate. Wright concludes by stating that the novelist tells a story of the "visionary reconstruction of Ghana." He indicates that this vision "has not been so subjectivised as to become historically unrecognisable" (27). That is, Wright argues, readers should dig deep into the The Beautyful Ones to uncover this vision that Wright could not discover himself. This is a laudable appeal since it would lead to what I seek to do in this thesis: discover the regenerative potential of Armah's work.

In a 1973 article, "No Saviours", Ama Ata Aidoo explains how she understands Armah's work. She admits that there "is something frightening" about The Beautyful Ones, and captures this as "the clarity with which he [Armah] has seen the African urban scene, as no visitor can be capable of, and the mercilessness with which he has opened it up - as no foreigner would dare do today" (16). As I will demonstrate later in this work, what is particularly important and relevant about Aidoo's remarks is that she insists that Armah's work is pertinent to the socio-political and economic context within which it was written. She argues that "this type of purgative exposure, however painful it is, is absolutely necessary" (18). Aidoo's conclusion on this matter supports my claim in this thesis, that Armah "does proclaim aloud a message to all, that the illegal consumption of the continent's strength and fertility" (18) should stop. Instead, a more Afro-Ghanaian-value-centred way of regrowth and development should be encouraged.

Finally, one other important article that emphasises the critical nature of this thesis is by Minna Niemi. Niemi's work demonstrates that the ethical choices of Armah's nameless individual are pointers to a better communal future. She argues that Armah pays "meticulous 
attention to individual attempts to devise a way out of the disillusionment that results when a united effort against corrupted power in the style of the decolonisation movement, has lost its effectiveness" (219). She further assesses the main character as being capable of active moral resistance to corruption and of individual thinking" (4). This is a productive reading of Armah's work and serves as the starting point for my own reading. However, Niemi's reading does not focus on the traditional Ghanaian values that I will argue serve as the basis for the main character's decisions and choices. Niemi's reading fails to recognise the qualities that make The Man capable of resisting the negativities around him: strong family values, honesty and hard work. In the next chapter, I will develop my argument that The Man is an icon of regeneration and a reconstruction of traits of Ghanaian national identity and that in these lies Ghana's future.

This idea of the process of regeneration in The Beautyful Ones amounts to a significant departure from other works of criticism on Armah. The notion of rebirth in my reading derives from the narrator's comment in the novel about the expectations for independence — "we were ready for big and beautiful things" (94) — and that "the promise was so beautiful. Even those who were too young to understand it all knew that at last something good was being born" (100). There are pointers in the novel to regeneration emerging from the decadence and corruption that has engulfed the independent Ghanaian state. I will show in Chapter 6 that Armah offers some hope for the nation after the independence experiment failed to produce any significant results, through an analysis of the characteristic traits and behaviour of The Man as a symbol of regeneration. 


\section{CHAPTER 6}

\section{THE MAKING OF "THE MAN" AS AN ICON OF REGENERATION AND RECONSTRUCTION OF GHANAIAN NATIONAL IDENTITY TRAITS}

\subsection{Introduction}

In chapter 5, we discussed the historical setting within which the plot of the novel is situated and looked at how the novel captures the various levels of historical occurrences as they affect the national, local, family and personal levels. In addition, we have looked at various critical reviews that The Beautyful Ones received and concluded that most of these critics have a negative view of Armah's first novel and those who are more positive in their criticisms tend to applaud the pessimism that others criticised Armah for. In this chapter, I will analyse Armah's work and argue that through the main character, The Man, and other narrative elements, Armah points to certain traits of Ghanaian national identity important for change and regeneration of the post-colonial society of Ghana and presents the possibility of hope. As we have seen in the work of Guillén, the examination of the problems of society offers the possibility of rebuilding it.

\subsection{The Making of "The Man" as an Icon of Regeneration}

In The Beautyful Ones, I argue, Armah goes beyond a detailed documentation of the causes of the decadence, corruption and disillusionment experienced by the masses after independence to present certain values vital to society. I will show that he proposes new notions of a unique "Ghanaian identity" that include hard work, determination in the face of oppressive socio-economic factors, and strict familial values, as a reaction to the "sons of the 
nation" who have taken over political power and are still following in the corrupt practices of the colonialists. In the novel, Armah gives his protagonist the generic title "the man," suggesting that he is an emblematic, Everyman figure. In doing so, he creates his protagonist as an icon of a specific incorruptible identity, which draws directly on traditional Ghanaian values. This representation, I assert, suggests a model for redefining, regenerating and rebuilding the future of the nation - in short, hope for change. The importance of the man's steadfast qualities becomes apparent in the social context Armah builds for him, a society in which almost everyone is drawn into the corrupt economy of greed and self-interest. Armah's other books such as Osiris Rising: A Novel of Africa Past, Present, and Future (1995), and KMT: In the House of Life (2002) offer similar visions of regeneration and regrowth. KMT indicates a "vision of future life" and of "a universe of no masters and no slaves, just equal persons sharing work and rest in respect" $(140,318)$, while in Osiris, Armah underscores working towards "a society without established hierarchies and privileges" (156).

Armah's first novel, I argue, can be read as affirming that, in spite of the decay and the decadence, society can benefit from a considerable level of regeneration and reconstruction if the model of The Man is adopted. In order to highlight how this purpose is to be achieved, this chapter explores the protagonist as an icon of the specific identity that Armah seeks to create. This model, Armah hopes, will help redefine the socio-political future of the nation, which, in the midst of corruption and decay, seems to be at a standstill with no visible signs of development—governments change but nothing else really does. In this chapter, I argue that in The Beautyful Ones Armah presents the main character as a template for the regeneration of the postcolonial society of Ghana and hence provides a more positive vision in his novel than other critics have noted.

Armah's personal experience had a major influence on his writing (Eloquence of Scribes 13). If in the novel he mentions and emphasises certain values of Ghana in the main 
character he calls The Man, presenting them as a tool for future regeneration and reconstruction of the postcolonial corrupt Ghanaian society, it is because he was brought up in an environment that gave him strong views about the retention of certain cherished traditional values. However, the values promulgated in the larger society, especially his school environment, conflicted with those he learned at home. He explains this conflict thus: "I grew up in a home environment that gave me a point of view from which I could see that the vision of reality that the established world offered me in its magnificent schools was an atrocious lie" (15). These influences described in Eloquence of the Scribes include the supportive nature of his father's family, clan and tribe, the joy of listening to the stories of the grandmother $(20,25-26)$, his negative attitude to matters of social privilege (29), his refusal to take higher salaries than others doing the same work $(101-103,126-127)$ and his intellectual curiosity. The values expressed in his personal life are those that he portrays in The Man: the need to remain truthful, having regard for loved ones, reverence for others, the importance of the nuclear, as well as the extended family, and the value of moral integrity and hard work respectively. The values of reconciliation and self-control can also be deduced from The Man's character in The Beautyful Ones. As a "serious African artist who combines the craft of creativity with the search for regenerative values" (Armah "Masks and Marx" 35), Armah imbues his protagonist in The Beautyful Ones with these values. This is the point of departure of Armah's cure for the ills of the nation. He seeks to resuscitate the hope of the nation of Ghana through planting the seeds of regeneration and regrowth in the form of the main character, The Man, with hope of those seeds germinating, growing and bearing fruit at some point in the future.

For Armah therefore, I argue, the main protagonist is an example of how his proposed project of regeneration can be achieved. Lazarus seems to affirm this position when he states, "contemplating the bleakness of the material universe that the novel postulates, many 
commentators have struggled in vain to retain their grasp on the work's vision of regeneration" ("Pessimism" 139). This reading is a laudable one and leads to the argument I present in this thesis. However, it does not show the traditional nature of the values that make The Man behave the way he does and influence his choices. In addition, Lazarus does not analyse how The Man displays these qualities. This thesis considers The Man as an icon of regeneration based on the values of the socio-cultural milieu that have made him who he is. Many critics have missed this point as they only consider the various derogatory labels assigned to The Man in the novel: the bus conductor calls him "a bloodyfucking sonofabitch" and "an article of no commercial value" (6). The driver labels him an "[u]ncircumcised baboon" and "a [m]oron of a frog" (10), while his wife Oyo calls him "Chichidodo" (52). However, in The Beautiful Ones, Armah shows a second perspective of The Man, different from the ideas of his fellow characters, as I will show in the paragraphs below.

The Beautyful Ones is a philosophical novel that interrogates how the main character, The Man, can traverse his corrupt society while trying to uphold his values of honesty and integrity. The Man's integrity undermines the glamour that the affluent and corrupt politicians in the society exert upon the populace and affirms the quest for a model of moral integrity that Armah promotes.

In the novel, The Man experiences a series of events and is then rewarded with the title of a "man of integrity". Critics such as Nnolim, discussed earlier, have analysed The Man's resolve to remain "clean," exemplified by the scraping of dirt off his shoes and his frequent bathing, (The Beautyful Ones 114, 139) as being unrealistic on many different levels and as symbolic of Armah's own undisguised philosophical pessimism and despairing view of Ghanaian society (Nnolim 207). Little, however, has been written about the protagonist's deep desire to remain morally upright. Armah shows that this pursuit of integrity is only achievable through physical, spiritual and moral suffering and repeated effort. As I will 
demonstrate, it is The Man's capacity to adapt to and endure all the conditions of life thrown at him that allows him to achieve this end.

In what follows I contend that his personality is being taken on a "journey"-we see him literally moving through his city—-through the complexities and dynamics of Ghanaian society so that he can be refined for the regenerative role that Armah's narrative sets out to perform through him. Through his actions, judgements and thoughts, we see his awareness of the socio-economic situation of post-colonial Ghana at his local level; we appreciate the lack of value for humans in the society around him and the ascription of importance to material wealth and the lack of confidence or trust in the post-independence Ghanaian bureaucracy. Firstly, I will unpack The Man's attitude towards the corruption and decadence in Ghana and his personal qualities, and then suggest the roles he plays in this process of rebuilding the socio-political terrain of Ghana.

\subsection{The Personality and Qualities of The Man}

Before delving into details about the characteristics that make The Man an icon of values worth pursuing in the quest to rebuild Ghana, let us look at an example of how the personality of The Man connects with the attitude of his society. The following incident, which occurs when The Man, in consultation with his wife, goes to the shop in preparation for the arrival of the Koomsons, clearly reveals some aspects of his personality and attitudes. The third-person narrator takes us through the thoughts of The Man and his assessment of the general economic situation around him: ${ }^{49}$

The day before, going into the shops with his new money in his pocket, he had had the uncontrollable feeling of happiness and power, even while knowing somewhere in

\footnotetext{
49 The long quotation is particularly valuable because it reveals many important aspects of the character of The Man.
} 
the back of his mind that the expensive things he was buying would deepen the agony of his next Passion Week. When he has asked for all that white man's food, the beautiful long grain rice in the packet with the Afro-American Uncle Ben smiling on it, [...], he had known it was stupid to be feeling so good just because he was buying these things he could not in the end afford, yet he could not help the smile that came to his lips and spread this feeling of wellbeing over all his body. If the aristocratic drinks, the White Horse whisky and the Vat 69, had been available then, he would have bought them gladly in the foolish happiness of the moment, no matter how bitterly he would have cursed himself later. It was not only because of the admiring glances of people in the shops, for whom the man's value could only be as high as the cost of the things he could buy. ... There was also, inside the man himself, a very strong happiness whenever he found himself able, no matter for how brief the spell, to do the heroic things that were expected all the time, even if in the end it was only himself he was killing. How was it possible for a man to control himself, when the admiration of the world, the pride of his family and his own secret happiness at least for the moment, all demanded that he lose control of himself and behave like someone he was not and would never be? Money. Power. (The Beautyful Ones 134-35)

In the passage above, Armah reveals The Man's thoughts on the main issues that cause people to chase after "the gleam" and behave as other people around them do. Indeed, this passage has been used by many critics (Ojong Ayuk 36-7, Terry Goldie 100) to depict the hesitant and unstable resolve of The Man, which, to them, ultimately leads to his anguish and despair and hence his inability to be a strong or worthy symbol of regeneration. However, upon a closer reading one realises that The Man is rather enumerating and delineating the causes of corruption and self-deception that have plagued the society after independence in a 
self-aware manner. The passage above illustrates The Man's foresight, his planning acumen and his consciousness of the general economic situation around him. He knows that even though there is an uncontrollable feeling of happiness when there is money in one's hand, there will always be a day of drought when one will have to go through the agony of Passion Week - the last week of the month before payday.

In lines 5 to 8, The Man shows his awareness of the consequences of over-indulgence in things that bring a temporary sense of self-worth to people but are not worth the financial pain in the long term. He calls the groceries he is buying "white man's food"- something that is exotic as compared to what he usually buys. He stresses the fact that even though he was buying these things, "he could not, in the end afford" them. The only motivation to do so is that he feels good about it now. On many such occasions, "the foolish happiness of the moment" ultimately produces what he calls "a bitter cursing of himself". The Man is aware that he is as susceptible as anyone else to the appeal of these products, but his sense of financial responsibility makes him equally aware of the consequences. In addition, his moral indignation and political awareness of the larger implications of small indulgences in luxury cause him both pleasure and disgust.

The final part of the quotation emphasises post-colonial Ghanaian society's penchant for material wealth and ascription of value to the "gleam", which ultimately results in a lack of value being given to human beings. The value that this society ascribes to people depends on what they have- their material possessions. Ojong Ayuk observes in relation to the novel that these values that people hold in high esteem "are essentially material. Accordingly, a hero is someone who amasses a substantial lot of blessings and the means by which he has obtained them are irrelevant" (36). What is evident in the above description is that most of these people, who go after the "gleam," as Armah describes it, do so because of societal pressure. This pressure is strongly suggested in the line "all demanded that he lose control of 
himself and behave like someone he was not and would never be" (135). The Man is tempted to lose self-control, and behave like someone he is not so that he can satisfy the desires and aspirations of his family and fit in with his society. The case of The Man suggests that social, rather than innate forces often control the action and inaction of members of society. For Armah's main character to be able to control this tendency and overcome the temptation that comes with it, he must go against social conventions or norms. To achieve this, in his portrayal of The Man, Armah goes to great lengths to elucidate differences between The Man and his colleagues at work on the one hand, and the corrupt nouveaux-riche represented by Koomson and the like, on the other. As such, although The Man is typically a modern man beset with challenges of survival in an unfriendly Ghanaian social system, he refuses to give up his ethical sense - even though he is aware of the conflict that this entails.

\subsubsection{The Man: a bulwark against corruption}

In The Beautyful Ones, Armah employs The Man as a means of exposing all the "particular signs that confer on the current African age its character of urgency" (Mbembe 15); that is, the corruption and decadence that is mirrored in the novel is seen and condemned through the eyes of The Man. In his attempt to remain honest, he exposes the greed and the corruption around him at the time of independence. Many associated the birth of the new nation with prospects of a bright future. In particular, the masses yearned for a free climate in which they might conduct their business and for a government that would respond to their needs and communicate with them in ways that they could understand. In The Beautyful Ones, The Man observes that even though the nation is born "anew," the situation of corruption that existed before independence has not changed: "[T]he same old stories of money changing hands and throats getting moistened and palms getting greased" are still there but, painfully, the 
difference this time is that "the sons of the nation were now in charge, after all. How completely the new thing took after the old" (11).

In the corrupt world painted by Armah, the only way out of poverty and lack is the pursuit of the "gleam" through bribery and deceit. As The Man observes, "[t]here would always be only one way for the young to reach the gleam. Cutting corners, eating the fruits of fraud" (Beautyful Ones 112). It is important to note here that the character appreciates the difficulty of living an upright life in this society but, instead of taking the easy way out — that is, giving and accepting bribes — he decides to, as Lazarus declares, fight "against the gleam" and "to conquer it by living positively in the face of its negatory imperatives" ("Pessimism" 162).

A typical case in point is his encounter with Amankwa, the timber merchant, which helps uncover a practice that has been accepted in Ghanaian post-independence society (3435). The merchant comes to a public office after working hours, asking for the allocations clerk in order to strike a private deal with him in order to facilitate the moving of his timber from the forest to the city. The Man's instincts prompt him to ask the visitor why he comes so late to a public office, to which the visitor replies: "But someone told me this was about the right time to come" (32) and "[A]ctually, actually, it is a bit private" (32) then adding, "Brother, brother, you also can help me" (33). The Man looks on without uttering a word and the timber merchant responds again, but this time imputing wrongdoing to The Man: "Brother, why are you making everything so difficult for me?" (33). His response and question takes The Man completely by surprise and he answers "Now what have I done?" (33). The third-person narrator's commentary in the text indicates that The Man's response came out "entirely by itself" (33), revealing the extent of surprise, confusion and weight of accusation that The Man felt. When Amankwa explains that he cuts timber and he is a contractor, one can feel The Man's suspicions about the merchant's purpose of visiting the 
office and realises that he intends to bribe him and therefore he replies: "If you can come back tomorrow... I have nothing to do with allocations" (34).

Immediately, this response sits badly with Amankwa, who, realising that The Man will not budge from his position, replies angrily, "I am not a child, my friend....You can see the clerk for me" (34-35). Again, the answer also gives the timber merchant the idea that The Man needs a bit of education on how things work in a public office such as his. He takes the opportunity to explain to The Man what has become the order of the day in society, what most people do and what he should do-people "eat" from their jobs and so must he. However, The Man insists that he does not have anything to do with allocation of freight carriages. Amankwa seizes the opportunity to offer him some money towards facilitating this process of "seeing" the other clerk: "[L]ooking in the wallet ...the fingers brought out two carefully held-out notes, two green tens. The man said nothing. Take it, the visitor said. One for you, one for him" (34-35). Here, Armah emphasises the kind of atmosphere that reigned in post-independence Ghana, at all levels, where one "must prosper" from one's work at the expense of the state and the citizens. Thus, the overt nature of bribery and corruption is depicted here but is not effective because of the very high moral standards of The Man and his lack of interest in the attraction of "the gleam".

The Man's character also reveals what Mbembe describes as the "distinctive mark", "the vocabularies" and the "eccentricities" of the post-independence nation of Ghana (15). In a conversation between The Man and the messenger in his office, we clearly see how certain ways of thinking and behavioural patterns have been accepted as normal. In the said interactions, the messenger announces to The Man his success in the lottery and his fears that he will not receive his winnings: "I know people who have won more than five hundred cedis last year. They still haven't got their money" (22). Recourse to law and order is not an option in this particular circumstance where everyone knows that the only accepted vocabulary is 
the giving and acceptance of bribes. If anyone seeks to follow the appropriate channels to get redress, he ends up paying more than he wins, as indicated here by the messenger's comment made with some bitterness, "You're joking... It costs you more money if you go to the police, that's all" (22). This intervention is significant since it exposes the fear of the clerk and confirms the difficulty that one faces in trying to abide by the law: it is a painful and costly thing to do. One cannot seek the intervention of the police without incurring more debt, so the simple solution is to hope that some official at the lottery place will take some of his money "as a bribe" and allow him to have the rest of it (22). The Man, who does not play by these rules of his society, accuses the messenger of intending to corrupt a public officer and the messenger responds: "This is Ghana" (21-22). This answer represents a clear indictment of post-independent Ghanaian society where corruption is prevalent. Through The Man's conversation with the messenger, we understand people's resignation in the face of deep issues of corruption and morality by which it is expected that a bribe will change hand for any transaction, and The Man's rejection of that acceptance.

\subsubsection{The Man as an embodiment of sobriety, responsibility and reflexivity}

The Man is shown as endorsing the fact that all must work towards ensuring that there is a proper functioning of the administrative systems of the nation. For the nation to get to the stage of regeneration and regrowth, the administrative and bureaucratic systems must work properly and impartially. As indicated earlier, The Man occupies a sensitive position-the maintenance of the smooth movement of people and merchandise by rail to and from the ports - and he is expected to follow established procedures so that operations at the Control Office run efficiently. The Man believes that when the systems function properly, people can access services without hindrance and on time. He therefore stresses the need for the administrative systems to run without interference. Robert Fraser emphasises the 
protagonist's insistence on the normal course of action. He maintains that The Man's attitude is that of "a straightforward insistence on taking prescribed procedures literally" (43). However, there is more to it than strict adherence to procedures. Rather, The Man's portrayal in the novel underscores Armah's view of the administrative system and implies that the only way to eliminate the dysfunctional system is for procedures to be followed without interference — society must work and systems must function. Furthermore, The Man's role as a railways administrator is not a coincidence- - he is a metaphor through which Ghana can reach its destination.

The Man is represented as exhibiting the character traits of sobriety and reflexion. He dedicates much time to pondering issues concerning his life, his family and the future. In one particular instance, he contemplates how people "chose to join the increasing numbers who had decided they were so deep in despair that there was nothing more to fear in life" (25). Therefore, they decide that they cannot do anything "to break the mean monthly cycle of debt and borrowing, borrowing and debt" (25). After contemplating this issue, he decides not to be one of those who accrue debt unnecessarily. The Man also shows sobriety in the way he reacts to issues. Even in the face of extreme provocation from his mother-in-law and his wife, he responds only after a period of silent reflection. These characteristics are demonstrated for example, when his wife, Oyo, accused him of being an "Onward Christian Soldier" and "a chichidodo" for refusing to take a bribe he was offered and hence denying the family and Oyo the opportunity to live "like Estella Koomson" who has someone to drive her and “smells sweetly of perfumes" (The Beautyful Ones 51, 105). The Man's response to Oyo’s demands sums up his demeanour and his belief about bribery and corruption: "But why should I take it?" because, “it wasn't even necessary". Next, he specifically addresses the issue of Estella, by telling the wife, "we don't know how she got what she has" (51). And in a provocative and disrespectful manner, the wife shouts back at him, "and we don't care" (52). 
She intimates that Estella's life is nice and clean, to which The Man replies calmly that "some of that kind of cleanness has more rottenness in it than the slime at the bottom of a garbage dump" (52). In these interactions, we see indications of Armah's conviction that situations and events should not push people into blind and impulsive emotional reactions. The Man therefore demonstrates here his visceral unwillingness to be corrupted or angered by insults because of social pressure and his association of corruption with filth.

Armah's depiction of these features of sobriety and reflexivity in The Man's character can be related to an age-old model of practical wisdom of the Akan (one of the Ghanaian ethnic groups to which Armah belongs), summed up in the maxim: "You first find an escape route before taunting the cobra" (Nebo 89). This model of pragmatic knowledge urges people to hold on to personal and communal integrity and to think actions through before undertaking them, and may be part of Armah's inspiration in creating the character of The $\operatorname{Man}^{50}$

This model is also represented by the popular adinkra graphic symbols, traditional representations of concepts and aphorisms about human and animal life and history. For the purposes of this discussion, two adinkra symbols are pertinent to the traits of sobriety and reflexivity I have identified. First is Akoma, the heart, that is rendered as "nya akoma" in Akan, literally meaning "look for the heart and have it". It represents patience and tolerance. Armah's protagonist can only survive in the post-independence Ghanaian society if he is patient and tolerant of the happenings around him but he also has to be steadfast. This leads us to the second symbol. This particular symbol is a snake trying to pass through the raffia tree, a concept expressed in Akan as "wo foro adobe". It symbolises steadfastness, prudence and diligence, as the raffia tree is a difficult one for a snake to climb due to its thorns (Azindow 32, Asihene 65). Armah's representation of The Man struggling through his

\footnotetext{
${ }^{50}$ Ayi Kwei Armah was born to Fante-speaking (an Akan group) parents in the port city of Takoradi, Ghana. He grew up listening to Abakosem - the narratives of people who had lived and died. These were ancestral narratives that explained the history of the people of the land (Eloquence 55).
} 
interactions with his society as he fights the attraction of the gleam is similar to the climbing motion of the snake. The Man intimates that even though it is difficult to forget about the gleam and its attraction, it is better for one to go softly and slowly, an attitude emphasised in the words of the song he hears on radio: "[L]et them go/ I will journey softly/ but I too will arrive" (60) - just as the snake slowly goes through the thorns of the raffia tree. Despite the challenges, once the snake is able to climb this thorny tree, it is able to enjoy its fruit.

\subsubsection{The Man and his family}

Another significant aspect of Armah's regenerative goal is The Man's portrayal as highlighting a kind of family life "that all can share in" (Mbembe 15) - a kind of relationship that the rest of society can easily identify with. The Man is characterised as the embodiment of a loyal, dedicated and responsible husband who takes care of his family - the smallest unit and the foundation of society — as best as he can. It is The Man's commitment to family responsibility that leads him to remain loyal to his household-unlike his friend, the Teacher-even though they do not always recognise his dedication to them. He continually warns them of the gleam of corruption even though they are determined to go after it. In a later novel, Fragments (1969), Onipa Baako, the main character cannot triumph over the forces that are pushing him to go after material things, consequently ending up in a psychiatric hospital. As Minna Niemi suggests, "Baako feels that he fails to fulfil his family's expectations because his own worldview directly clashes with theirs. He is expected to bring material wealth to his family, but, if he did so, he would need to betray his own ideals and play the corrupt national games that he despises" (288). This is not the case with The Man in Armah's first novel who is able to resist the attraction of the gleam and remain morally upright throughout the novel. 
In The Beautyful Ones, The Man triumphs over the accusations of his worst critic, his wife, Oyo. As a case in point, Oyo and the mother-in-law decide to collaborate with Koomson in an illegal procurement of a boat against The Man's wishes and, in opposing the deal, he incurs the wrath of the old woman. As the deal goes through the process of frantic verbal negotiation, The Man cannot help but laugh at the old woman's eagerness to see the deal sealed and the prospects of fish that the boat will bring to the family by saying "[Y]es, we shall be rolling in fish. ... And you will have a boat in twelve years, perhaps" (164). Oyo defuses this tense atmosphere by pulling the arm of her husband before he says more, but the hornets' nest has already been stirred up. His mother-in-law, obviously angered by the comments from The Man spits violently on the ground saying, "Foolishness ... Sheer foolishness" (164). The Man, now knowing the extent of the damage caused, turns back to say good night to his mother-in-law but "[h]is good-night went ringing through the night, unanswered". Worse, he "thought he heard something said about useless men" (164).

The Man's steadfastness with his family is contrasted with the behaviour of The Teacher, his character foil, who decides to abandon his family because of the pressures they pile on him. The Teacher declares: "I have spent so much time running from it [family and family issues]. Yes, but I am not free. I have not stopped wanting to meet the loved ones and to touch them and be touched by them" (64-65). In contrast to The Man, The Teacher considers the loved ones as "dead people" — a deadly and suffocating family life —and observes that going back to them will be going back to dead people "and their embrace will be a welcome unto death .... And so I run" (65). And yet, without his family he is not necessarily happier. While The Man stays loyal to his family in the midst of the taunting from his wife and his mother-in-law, the character who acts as his advisor and confidant in the novel decides to run. In juxtaposing these two characters, The Man's strong sense of loyalty and commitment to his family becomes even more apparent. 
There seems to be a constant push towards alienation from The Man's family because of their demands but, like the proverbial snake, he confronts this push in a brave manner by returning home (climbing the tree) each day after work to meet the flat eyes of the wife. As the narrator describes it, her eyes are those of "a person who has come to a decision not to say anything; .... And because these eyes are there the air is filled with accusation" (49). When he cannot endure the eyes of the loved ones any longer, The Man conveys his feelings in a silent, but loud apostrophe: "O you loved ones, spare your beloved the silent agony of your eyes" (49). The importance of unity as a vital family value for Armah as a writer is also depicted in his dedication of parts of chapter 4 and the whole of chapter 5 to how loved ones make or unmake people. Chapter 5 starts in this way: "The reproach of LOVED ONES comes kindly when it comes in silence" (52). He indicates at the beginning that the issue of loved ones and the pain they can cause or the joy they can bring to one's life will be addressed in the chapter. In order for the family to survive the turbulence of the post-colonial socio-economic realities, they have to stay together, strive together for the highest moral values and have a strong head of family who will resist the unnecessary demands of other family members.

The relationship between The Man and the wife is a template for a close-knit postindependence Ghanaian family relation. Although in The Beautyful Ones Armah is not overly concerned with what occasioned a change from strong family ties, values and aspirations to a more individualised, closed and alienated kind of family, one cannot turn a blind eye to his desire for a strong traditional family relationship. He makes clear the kind of family ties his main characters have. Some are dysfunctional: the Teacher could not live with his loved ones and The Man's friend Maanan could not sustain any of her love relationships. On the other hand, The Man himself has a close relationship with his wife and children, despite the conflicts already described. We see hints of this friendly rapport in the incident in which The 
Man is seen standing by his wife and "resting a light arm on her shoulder" (135). There is another occasion when, for the first time in the novel, the woman is observed eating with the husband. Later, we see The Man and his wife exchanging pleasantries as Oyo is combing her hair with a red-hot metal comb $(140,151)$. And of course, finally we see her appreciation of his integrity. Even the corrupt Koomson has a wife and children and they have a good relationship with each other.

The other family-like alliance is that of The Man, Etse, Kofi Billy and Maanan. Their camaraderie echoes the values of the traditional family-oriented structure of Ghanaian society. We see in-depth descriptions of the long-lasting friendship between the three of them as they share companionship in various forms, for example, smoking wee (marijuana), drinking schnapps and other hard liquors and sharing time together at the beach and at political rallies. This description also points to the causes of breakdown in certain aspects of the traditional patterns of society-alcohol, drugs and unemployment-and draws the reader's attention to it. The solutions Armah provides to the negative consequences of this breakdown in the family system can be inferred from the relationship that finally results from The Man's interactions with his wife. At the end of the novel she expresses her appreciation of him, holding his hand tightly and saying: "I am glad you never became like him [Koomson]" (194). This conciliatory gesture can be interpreted in three ways: first, it could mark the beginning of her appreciation of The Man's steadfastness and resilience in the face of all the corruption and decay; secondly, it also suggests her newly discovered support for these values that have been eroded by the incessant quest for money and material things. And thirdly, it could be seen as The Man's reward for his efforts to remain with the family, despite her temper tantrums and name-calling. 


\subsubsection{The Man in the work place}

Another aspect of the character of The Man that Armah implies is needed for the regeneration of postcolonial Ghanaian society is his espousal of the ideals of hard work, punctuality and a strong sense of duty - the official party ideals proclaimed by all the speakers at political rallies in the text. The character of The Man embodies these ideals as he interacts with and encounters other characters in the novel. In The Beautyful Ones, The Man exhibits extreme punctuality in his daily routine,-- sometimes arriving before the cleaner comes to the office and thus demonstrating a strong work ethic. He is always at his desk making sure that the railway system works properly. What is more, he does this job without any expectation of extra reward in return, as seen in his refusal of the bribe offered to him. Moreover, at the end of the novel, when asked why he did not participate in the demonstration in favour of the new government, he replies, "If two trains collide while I'm demonstrating, will you take the responsibility?" (186). The Man's attitude at work stresses the vital point that the new nation of Ghana can only be reconstructed as a better society when people are responsible in and for what they do. Indeed, in the course of being responsible, people should exhibit a sense of duty to work and this will eventually contribute to the betterment of society and not the perpetuation of self-indulgence and self-gratification.

The Man is portrayed as a symbol for the Ghanaian values of communalism, unity and cooperative action. As a leading African Christian religious philosopher John Mbiti explains in African Religions and Philosophy (1989), when individuals are responsible for their actions, they extend this responsibility to the community and this reinforces corporate group responsibility. At this level, avenues are created for the maintenance of communal unity and moral standards (201). In the novel, The Man helps Koomson out of trouble by letting him escape through the pit latrine of his house and through the grounds to the seaside. For the human capacity of unity and cooperative action to be achieved, there is the need for 
postcolonial Ghanaian society to look beyond the decadence and the corruption to recreate a new society based on unity, corporate responsibility and human relations. This new society cannot be built on destruction of property or the maiming, lynching or killing of corrupt officials, but the implementation of what Carl Ratner the cultural-psychologist calls "concrete cultural-political action" (31). As another leading African philosopher, Kwame Gyekye, also explains in An Essay on African Philosophical Thought: The Akan Conceptual Scheme (1995), in the context of Akan "social and humanistic ethics," an action is deemed morally suitable mainly if it improves the welfare of the society, and fosters "solidarity, and harmony in human relationships" (132). Therefore, moral worth is "determined in terms of its consequences for mankind and society" (132). Armah, being in tune with the socio-politicocultural repercussions of the coup d'etat in the novel, portrays The Man as a channel of peace and reconstruction — he protects Koomson from the angry mob. In this manner, Armah adopts a humane and viable approach to dealing with the chaos that emanates from the coup and the consequent mob actions.

On a different, yet related note, the use of the term "brother" in dealings with The Man is symbolic as it reflects the idea of brotherhood and community relationships advocated by Armah in postcolonial Ghana. The word appears in many conversations and it is used not in the original sense of blood relation or familial attachment, but rather as a term of address for members of one's community. This sense encompasses friends, people who are regarded as friends, people that speak the same language, who share the same customs and manners. In The Beautyful Ones, Armah uses "brother" in some of the instances below: when the conductor extends his cigarettes to The Man, "brother, you care for jot?" (5); when the timber merchant pleads with The Man to help him cart his logs "Brother, brother, you also can help me" (28); when The Man's mother-in-law addresses Koomson as "Brother Joe. Brother" (58); when the taxi driver taking The Man and his wife to the Koomsons' responds to The 
Man's conversation "you have said it brother" (140). With the number of times that the word is used, one cannot ignore its import in the text. In all the instances cited above, "brother" conveys linguistically the sense of community that Armah seeks to propagate among the society of postcolonial Ghana, reinforcing socio-cultural beliefs and tenets of unity in Ghana. The word "brother" has its equivalence in most Ghanaian languages and its significance, while similar to the English version, goes further to encompass distant cousins and non-blood relations. "Brother" is "me nua" in Twi, "anyemi" in Ga, "norvi" in Ewe, with all of these meanings reinforcing a sense of unity and goodwill. For Armah, this form of address is significant since it engenders a sense of belonging and contributes to the desire to work collectively. Indeed, all these are virtues which are sadly, however, not a priority for Koomson and other party men.

\subsubsection{The Man and African authenticity}

Also vital to Armah's project of regeneration and regrowth is the portrayal of The Man as steering clear of pretence and maintaining his dignity. The Man is depicted as an "authentic" local person who does not aspire to be a European by consuming foreign products or changing his name. When his wife, Oyo, tries in a cunning ploy to find out exactly what kind of drinks her husband will get for the Koomsons' visit by saying she does not like "made-inGhana spirits", The Man gives his wife a long lecture which ends with this conclusion: "Besides, there is nothing wrong with beer. After all, Koomson knows we are not rich, so why should we pretend?" (135-36, emphasis mine). This attitude of eschewing pretence is reflected also in the quotation cited at the start of this chapter that recalls The Man's determination not to buy things on credit as his colleagues do, thus pretending to live a lifestyle they cannot afford. Estella Koomson, the man in the Control Office and some Senior Civil Servants reveal this tendency of pretence and lack of confidence in self in the way they 
dress, act and live. Koomson's wife prefers European drinks to local ones as the local beer allegedly does not agree with her constitution and, according to her, buying them is a waste of money (154-56). In the Control Office, we see one of the clerks, who is referred to only as the "little man," make a hilarious attempt at speaking like an Englishman while conversing with The Man (28).

In the opening section of The Beautyful Ones, Armah presents us with individuals showing symptoms of being bitten by the bug of "Europeanism", whom he calls "the dark ghosts of a European" (95). These people readily dismiss anything local in favour of foreign alternatives, especially regarding where they choose to live and the names they adopt. The higher-level civil servants live in the Upper Residential Area and the Esikafo Aba Estates ${ }^{51}$ with white men, party men and lawyers, and change their names to sound like European names, which try "mightily to be white" (147). The Man walks through this area and, in his thoughts, mocks some of these names in detail, as we can see in the following quotation:

In the forest of white men's names, there were the signs that said almost aloud: here lives a black imitator. MILLS-HAYFORD... PLANGE-BANNERMAN ... ATTOHWHITE ... KUNTU-BLANKSON. Others that might have been keeping the white neighbors laughing even harder in their homes. ACROMOND....what Ghanaian name could have been in the beginning, before its Civil Servant owner rushed to civilize it, giving it something like the sound of a master name? GRANTSON... more and more incredible they were getting. There was someone calling himself FENTENGSON in this wide world, and also a man called BINFUL. (147)

As can be seen, Armah is very critical of those Ghanaians who have aspired to a more fanciful and status-changing European culture, as seen above. This vehement criticism of these lifestyles is in line with Armah's strong desire to validate and renew a culture that some

\footnotetext{
51 "Esikafo Aba" literally means "the rich/wealthy men have arrived," hence denoting the existing divide between rich and poor in post-colonial Ghanaian society.
} 
Ghanaians have rejected for foreign ways of life, though this alien culture does not help in regenerating life or preserving it, but rather promotes death. Rama Krishna, whom Armah describes as a Ghanaian who takes a far-off name and who involves himself in meditative exercises and special diets as he begins the project of reincarnation of his soul, does not succeed in this quest, but rather ends up with his entrails decaying and his heart eaten up by worms (55-56). Rama Krishna's example is a case of an adoption of a new identity-through a new religion-but ultimately he fails in his attempt to "escape from corruption and of immorality" external to him, as "his body inside had undergone far more decay than any living body" (56).

Pretence aside, through The Man's character, we observe situations of trickery and deception of the masses by the politicians. As the novel progresses, Armah shows us people being deceived and tricked into believing that promises that were made to them before the political parties took over power would be fulfilled. The Man's mother-in-law for instance is a victim of such a deception, as she believes the fishing boat deal will make her rich. The Man, however, is depicted as someone who is not swayed by false promises from people or politicians. At a political rally, The Man observes: "[I]t is not true at all that when men are desperate they will raise their arms and welcome just anybody who comes talking of their salvation .... But we did not run out eager to follow anyone" (94). This observation by the Man stresses the need to retain an objective perspective of what politicians and political parties promise during campaigns and what should be expected from them after they come into power so that one is not overly expectant. This reflexion is also a timely warning to politicians and their henchmen that after enduring a certain period of trickery and deceit, people will rise up and fight for their due: "One man, with the help of people who loved him and believed in him, had arrived at power and used it for himself' but now the people turn on him, singing "old songs with the words changed from the old praise for Nkrumah to insults 
for him" (185-86). In effect, authenticity is key to sustaining one's legitimacy while in power and it is equally important when one wishes to set an example for others to follow.

My argument in this section is that Armah presents the main character as having certain characteristics that make him a symbol or an icon for regeneration of the postcolonial society of Ghana and hence provides a more positive vision for the possible future of Ghana. I have argued that the character of The Man is a blueprint for regeneration of the postcolonial Ghanaian society since he stands firm in his values, and is true to himself, maintaining a positive outlook on life, in the hope that things will change in the future. This possibility of regrowth and regeneration is also reinforced in the other details of the text.

\subsection{Symbols and Indications of Regeneration and Regrowth of Ghanaian Identity in The Beautyful Ones Are Not Yet Born.}

In this section, I examine Armah's use of imagery in The Beautyful Ones. I will demonstrate how the title of the novel, The Beautyful Ones..., the use of Sankofa as a symbol of hope, and other images depicted in the novel support the argument that Armah seeks to regenerate and redefine the post-independence nation of Ghana from its state of decadence and corruption in his work.

The very title of the book The Beautyful Ones Are Not Yet Born is evocative: of the sense of a nation not yet born, lacking the beauty it might achieve, yet full of possibilities. It is the first thing we see on the cover of the book and it returns at the end of the novel, painted on the rear of a moving bus. The title does not refer to any specific time or period of the conception and birth of these "beautiful" people or their identity. It does not spell out the gender of these people nor their social status. Instead, it stands for a collective, a group that will appear at some time in the future to redeem the nation from corruption and decay. The non-specific nature of the "beautyful ones" shows no prejudice or pre-conceived idea about 
the kind of regeneration and regrowth Armah anticipates. Rather, the misspelling of the word "beautiful" could also represent the expectation of something of beauty that will be complete, full in the future (beauty + full). This future-oriented expectation of a new beginning is underscored by the word yet-an acceptance of a potential or a latent energy waiting to explode at its birth.

In a recent interview with Morehouse College in 2016, when Armah was asked to explain the title of his book, he intimated that "the beautyful ones" is a concept he took from ancient Egyptian mythology that refers to four people, two males and two females. These were brothers and sisters whose names mean "the beautiful ones" and they took part in great inventions and discoveries to help their country. Their core tenets of social harmony included the spirit of collaboration, the desire to work to improve the lives of everyone and using "beautiful" means to make everyone happy. Armah goes on to explain that these people could be a mythical representation "of all those people who sit up all night watching the stars, finding ways of calculating distances ... writing things down and archiving" ("Global Conversations with Dr. Ayi Kwei Armah"). From this description, The Man could be seen as a precursor of these beings, thwarted by the incomplete transformation of his society.

The appearance of the title on the back of a moving bus is also significant. This is a kind of public transportation, an instrument of social mobility, which is called "trotro" in Ghana and is the most popular means of mass mobility. The title's appearance here, "carefully lettered to form an oval shape" making it very striking, will resonate with the people who are waiting for the day that their situations would change - the day the beautiful ones will be born (214). The driver of the bus that carries this relevant message is seen smiling and waving to The Man, the character who stands for the fulfilment of the message that the bus is disseminating to the masses. This is a subtle endorsement of The Man and his 
principles. In fact, the bus is not static; it drives away, into the future where the "beautyful ones" are expected to be born.

Stylistically, Armah as a postcolonial engaged writer adopts a vivid style of writing, which allows him to dig deep into the waste around him, paint a picture of it and still bring out glimpses of beauty and hope. Through this same medium of waste, which surrounds The Man, the morals of the main character are refined and, by extension, those of other characters that need to be "morally cleansed" of the endemic corruption of society. The Man's immersion in the decay of his environment and his struggle against it could be seen as an example of how others in similar situations have to suffer humiliation before their family and relatives because they have refused or were unable to follow the gleam. Koomson's emergence from the latrine at the end of the novel reveals what happens when the gleam finally catches up with those involved in it and natural justice is applied. More importantly, Armah's detailed description of the rot and decay makes the smaller but important hints of beauty and hope stand out. The reader heaves a sigh of relief at breathing in unpolluted air and sighting clear seawater as s/he turns the pages of the novel. Out of the decaying and putrefying situations that the novel describes arises the hope of new things to come.

The emphasis on decadence and decay is in itself linked to re-birth. The Man remembers an earlier conversation with the Teacher about this fresh beginning-the idea of the cycle of life - and reflects on how soothing these words were to him: "[Y]et out of the decay and the dung there is always a new flowering. Perhaps it helps to know that. Perhaps it clears the suffering brain" (99-100). The second part of the sentence points to the need for the creation of awareness among the citizenry for a future. The knowledge of this future hope will clear the mind and serve as a consolation. Certainly, in this future there is the possibility of regrowth in postcolonial Ghana. 
Armah's narrative vision in The Beautyful Ones is to tackle both the social and the aesthetic, and in doing so, he combines both the transformative and the innovative in his work. In "Regimes of Waste: Aesthetics, Politics, and Waste from Kofi Awoonor and Ayi Kwei Armah to Chimamanda Adichie and Zeze Gamboa," Connor Ryan emphasises the use of waste, decay and disintegrated values as a source of renewal for social bonds (51). Armah's work too strives towards the regeneration of social bonds that have been eroded by the corruption and decay present in his society. In the novel, we see evidence of the demise of those who are stuck in waste, decay and destruction-Koomson's fate. And when Oyo, the Man's wife declares, "I am glad you never became like him" (194, emphasis mine). She is rewarding him or validating his struggles against the "gleam." What is significant here is Oyo's use of the word "never," showing her recognition of her husband's consistent virtues. Her acknowledgement of The Man's integrity is a stamp of final approval of Armah's model, which is a springboard for the rebuilding of the nation of Ghana and also shows how her attitude has changed as I will discuss in the next chapter. Thus, Armah's regenerative purpose in the book is set out, carried through and maintained until the end-The Man will not end up like any of the corrupt politicians.

\subsubsection{Sankofa}

The fleeting but repeated mentions of birds in the novel $(52,56,62,113$, and 215) hints at the cultural notion of the sankofa bird, a concept taken up by Armah in his memoir, Eloquence. In Ghanaian cultural traditions, the sankofa bird is portrayed as walking forward but turning its head back to pick up what is depicted as an egg. Sankofa, as Dorothy Williams observes, in Akan means "go back to the source and take," and it is captured in the maxim "se wo were fi na wosan kofa a yenki"; literally, "it is not disgraceful or taboo to go back and retrieve what one left in the past" (172). This concept refers to the process of returning to the past and 
retrieving what is left there in order to use it for the development of the future. It emphasises a blend of progressive human values from the past and the present, which the creator of African American holiday of Kwanzaa, Maulana Karenga calls "models of human excellence" (39), as a foundation for rebirth and growth. Within this framework, Armah conceives of his work as a griot's insight into the past of Africa and the retrieval of this history in Eloquence along these lines: ${ }^{52}$

An iconic presentation of the griots' insight — that with the triumph of the Europeans Africa entered a time of loss, and that we have important memory work to do if we are to recover what we lost-is the image of the Sankofa bird. The bird is shown in mid-flight: history flows on. Its forward motion is not in doubt; nevertheless, the bird is aware of having dropped something valuable, indeed, indispensable. It, therefore, casts its vision backward, not with any intention of reversing time and returning to the past to live there, but with the purpose of retrieving from past time just that element of value that should not have been lost, prior to continuing its interrupted motion. (Eloquence 118)

The above indicates Armah's awareness of the need to recover from past traditions those elements that are important in the process of reconstruction and regrowth. He buttresses the need for recovery from the past thus: “[T]he active interaction of a society's present with its past, oriented to its future, is the key to the embrace of history as a resource, an understanding of memory as the venue of inspiration" (Eloquence 264). For Armah, the act of recalling and representing Ghana's painful past and its corrupt present and decay is a way of countering individual and collective amnesia. He also sees it as a means of preparing the minds of younger politicians for what they should expect when they are in power. Mbembe is also of

\footnotetext{
${ }^{52}$ A griot is an indigenous oral and cultural historian. The term originates from West Africa. For more on this, see the works of Barbara G. Hoffman, Griots at War: Conflict, Conciliation, and Caste in Mande (2000) and Steven Green and Karen Richardson, T Dot Griots: An Anthology of Toronto's Black Storytellers (2004).
} 
the view that the misbehaviour of the sons of the nation when they came to power is mainly "founded on a specific form of forgetfulness" (145) as to their purpose of developing the nation and improving their living conditions, and it is this that sankofa fights against. Anyidoho too discusses the work of Armah in relation to the importance of sankofa as a symbol of hope. He calls it "a view of life in which the present is in a constant creative interface with the past, but always with an expectation of future harvests as their essential driving force" (5). This perspective is noteworthy since it reveals Armah's efforts to explain the history of Ghana, with its attendant (though often betrayed) expectations for independence and for liberty and prosperity.

The sankofa technique also allows Armah to take us on a journey through the daily lives of the characters in the novel, their pasts and present conditions of life. We understand the relationship that exists between The Man and the Teacher and their families, and the pain and anguish they have to go through with these loved ones. Armah offers a nostalgic description of how things used to be. The Teacher's thoughts in his conversation with The Man encapsulate this nostalgic memory of the past: "I had so much hope before... so much hope.... There used to be something, and you know what I mean" (70-71). To succeed in changing the future of Ghana, as an engaged, Armah must unearth those aspects of society that are unproductive (all the decay) so that they can be seen for what they are in order to create an avenue for change by the use of sankofa. He must also reveal those traditional timetested values that are important for regrowth, such as honesty, integrity and hard work in the character of The Man. By focussing on the knowledge of the past, the postcolonial Ghanaian society will be able to remember and retell what happened in the past and to recover the values needed to prepare itself for the future for regrowth and regeneration. 


\subsubsection{Redemption and rebirth}

A number of symbols and images in the novel point to the possibility of rebirth or redemption. Armah uses these to describe events and situations in graphic detail, such that the reader gets the impression of virtually feeling and smelling what he describes and $\mathrm{s} / \mathrm{he}$ is thereby compelled to come face to face with the reality of dirt and the canker of corruption. Such an encounter, it is hoped, will eventually lead to regeneration and regrowth when people no longer indulge in corrupt practices but rather work towards the progress of the nation. One element of regeneration is seen in the strong imagery of Koomson's escape through the latrine at the end of the novel—both a punishment and a metaphor for his sin of corruptiondepicting the end of an era, and the ushering in of another one. For the central figure of corruption to be re-admitted and eventually reintegrated into society, Armah has him go through a cleansing rite of passage. In the novel, Koomson is seen going through the pitlatrine full of faeces and urine before he can escape to the sea. This is a culminating moment of Armah's aesthetic confrontation with and denunciation of corruption in the novel and the opening up of avenues of rebirth—a new personality for Koomson and society. In his article "A Connection of Images: The Structure of Symbols in The Beautyful Ones Are Not Yet Born", Terry Goldie maintains that in going through the latrine, Koomson is "figuratively going through the process of expelling the inner decay and of dealing with the natural man" (104). This process enables him to be purified of the corruption and decay in which he has immersed himself and be reborn. In addition, it is only after the purification that he can be reintegrated into the society that he has betrayed through his corrupt practices.

However, Wright is of a different view, arguing that Armah fails to achieve his aim of ridding the nation of corruption. He notes that Koomson's unpunished escape at the end of the novel and its implied purification rites do not constitute any bold attempt to rid the nation of corruption and decay (30). Nevertheless, as has already been noted, Armah's vision is to 
purge the local society of its greatest negative influence, Koomson, and he does this through the rite of passage - the escape via the latrine into the sea before being finally sent off to Ivory Coast. Koomson cannot be allowed to remain in the society while the situation of corruption is being dealt with. Significantly, after Koomson's departure and as the work concludes, The Man sees "a single flower" (214).

\subsubsection{Glimpses of hope}

This flower at the end of the novel is another significant image of regeneration. Appearing on the back of the van, this flower is a brightly coloured symbol located in the middle of the writing that bears the title of the novel. It stands for beauty and a new beginning, a rebirth after all the decay and corruption experienced by society. Its appearance at the end of the novel is also significant, a reminder that, after all The Man's struggles to stay clean, there is hope: "In the centre of the oval was a single flower, solitary, unexplainable and very beautiful" (214). The reference to the prospect of a new birth or hope as indicated earlier is reinforced here with the words describing the flower as, "very beautiful" and this time, the word "beautiful" is written correctly. Moreover, the hope comes in the germination of The Man's seeds of uprightness and hard work. The flower's disappearance and its replacement by "a single, melodious note" (214-15) are crucial to the theme of regeneration. It points to a future of possibilities embodied in the flower and in the melodious sound.

Music also appears earlier in the novel with a message of hope. In an earlier scene, The Man and the Teacher listen to a series of songs being played on the radio. The Man describes the first song as "a sweet sadness of a song", (58) which is immediately followed by another one, a more lively highlife. ${ }^{53}$ Moreover, just after this song comes what he describes as "another, slower softer song" (59). To The Man and the Teacher, these two

\footnotetext{
${ }^{53}$ An indigenous Ghanaian musical form that became popular in the nineteenth century. It is a combination of traditional musical rhythms and melodies, which is played with foreign or Western instruments. It became popular in West Africa at the later part of the century. See John Collins, "The Early History of West African Highlife Music", 221-30.
} 
songs following each other is a miracle (59). The songs are indications of changes, motion and renewal. The last song has a profound impact on The Man, making him think positively about life and the fact that no matter how slowly, once there is motion, change will surely come:

Those who are blessed with the power

And the soaring swiftness of the eagle

And have flown before,

Let them go. I will travel slowly,

And I too will arrive. (59)

After listening to the song, The Man and the Teacher are curious to find out what makes the writers of the song have such hope and aspiration that they too "will arrive" one day. In addition, the song echoes, for them, the vital idea that with determination and hard work, no matter the present position and condition, growth and rebuilding can be achieved in the future. Armah looks forward to the day that "the beautyful ones" will be born and the nation of Ghana will be fully put on the path of restoration and development. The initial appearance of the songs and the final appearance of music in "a single melodious note" (215) are significant moments and a high point on which Armah ends the work. This "victorious" ending of the work is substantiated by the reappearance of a bird - the "sankofa bird" - with another song, which is described as "strangely happy"- -happiness at the prospect of a future time of a new birth (215).

There are other instances of hope in the novel. Early on, The Man perceives smooth pebbles with clear water flowing over them: " $[\mathrm{H}] \mathrm{e}$ drew back his gaze and was satisfied with the clearness before the inevitable muddying. It was a satisfaction of a quiet attraction, not like the ambiguous disturbing tumult within awakened by the gleam" (27). The Man appreciates the natural beauty around him, which he compares to his inner desire and the 
struggle to resist the attraction of the gleam. Further, he compares the clearness of the water to the dirtiness of the gleam and expresses his preference for the cleanness of the water thus: "[A]nd yet here, undoubtedly, was something close enough to the gleam, this clearness, this beautiful freedom from dirt. Somehow, there seemed to be a purity and a peace here which the gleam could never bring" (27). In the eleven lines of this paragraph on page 27 , we see many words that emphasise that moment of peace and tranquility when there is no contamination or blockage to growth. The phrases, "clear water", "beautiful freedom", "the sea", "the stream", "quiet attraction", “clearness", "satisfaction”, "satisfied”, are all enhanced by the words, "peace" and "purity", and hence accentuate the nature of the new birth that Armah is seeking for post-colonial Ghana. The beauty of the stream and the pebbles are escape routes to freedom, avenues to the cleansing of the dirty self and the beginning of a new life of freedom. On another occasion, he sees the seawater to be clearer than he thinks (139), and he observes a sweet breeze on the bridge where he used to walk (145). These hints and glimpses of clean beauty strengthen the observation that "out of the decay and the dung there is always a new flowering" (199-100).

\subsection{Conclusion}

Ayi Kwei Armah promotes in his novel The Beautyful Ones Are Not Yet Born certain notions of Ghanaian identity conducive to regeneration and reconstruction of a just socio-cultural milieu in post-independence Ghanaian society. These notions, largely exemplified in the character of The Man (the protagonist of the novel), serve as the basis for a discussion of the possibility of the birth of the "beautyful ones" in post-independence Ghana. I argue that Armah's novel sets out the canvas for that new birth that will eventually lead to regrowth and development. Armah brings a fresh approach to notions of national identity that are 
invaluable in the attainment of regeneration and regrowth, as he highlights The Man's hard work, his determination in the face of opposing socio-economic factors, and his strict familial values.

As a social physician, like Guillén, Armah keeps his creative stethoscope close to the heartbeat and pulse of the society of Ghana, diagnosing its problems, and proposing solutions in the form of the upright character of The Man. These qualities, when extrapolated from The Man's personal level, to his family level and to the level of the wider society, will reverberate throughout the nation. Their impact will eventually culminate in the regeneration and regrowth that Armah seeks for the post-independent Ghanaian society. This hope is also reflected in the traditional symbol of sankofa that stresses the importance of learning or, retrieving from the past, progressive human values for the development of the future. Regeneration is also indicated by tiny but powerful glimpses of natural beauty that capture the attention of the reader as s/he heaves a sigh of relief at the sight of these elements.

In the next chapter, Chapter 7 "The Representation of Women in Armah's The Beautyful Ones are Not Yet Born" I will explore the extent to which Armah's novel expands the traditional limited roles of women in post-independence Ghanaian society to include more significant and relevant roles. I will argue that, he moves away from a vision of Ghanaian women in roles such as wives and sisters and emotional supporters to more empowering ones, such as being the sources, custodians, and repositories of knowledge for their family and the society. As with Guillén, the status and role of women in their respective societies is shown to be crucial to the possibilities for positive transformation. 


\section{CHAPTER 7}

\section{REPRESENTATION OF WOMEN IN ARMAH'S THE BEAUTYFUL ONES ARE NOT YET BORN}

\subsection{Introduction}

The post-independence life of Ghanaians was saddled with poverty, corruption and lack of trust in due administrative process. Although the nationalist leaders (the indigenous citizens who came to power after independence) assured the citizens of a better future, postindependence society was still beset with uncertainties. Women and children bore the brunt of the poverty, decay and corruption that engulfed all levels of society, from people in high offices to the labourer or the farm hand or the office clerk. However, the few women that appear in Armah's The Beautyful Ones have, as I will demonstrate, qualities that enable them to navigate the tortuous waters of post-independence life in Ghana. This representation sets the stage for Armah's effort, as he indicates in an interview at Morehouse College, to portray women in a brighter and better light than other male African writers of his time-as assertive and strong, risk-takers rather than weak and dependent people.

After having argued that The Beautiful Ones presents a more positive and regenerative perspective than most critics allow, in this chapter I discuss an important element in Armah's quest to make Ghanaian post-independence society "whole". This process of rediscovery will involve re-examining the feminine characters of the novel with a view to exploring what makes them significant players in the re-building of a post-independence Ghanaian sociocultural fibre that had been eroded by corruption and bribery. As Armah rightly indicated in an interview at Morehouse College, "no society can be whole if it is run entirely by men" ("Conversations with Dr Ayi Kwei Armah). Just as he develops an image of The Man as a symbol of regeneration and regrowth of the society in the work, he also plants the seeds of an 
empowering image of women, a feature seen also in the work of Guillén as I indicated in earlier chapters. After examining the life of The Man, it is important to examine the "strong" women that Armah creates around this figure. I claim that in Armah's The Beautyful Ones, we see an intent to portray women in a positive way, an aspect of the novel which has not yet been explored in criticism of this novel. I will further analyse whether these initial images develop, alter or are sustained as the work comes to an end. This chapter is divided into 4 sections. This section introduces the chapter and the arguments to be expounded in it; Section 1 outlines existing critical views of the representation of women by Armah. It also describes the historical and traditional context of women's roles and representation in The Gold Coast and Ghana. Section 2 discusses the representation of Ghanaian women in literature in general, in Armah's other works and, specifically in Armah's The Beautyful Ones and Section 3 concludes the chapter.

\subsection{Armah's Representation of Women in the Context of The Gold Coast and Ghana}

\subsubsection{Critical views of Armah's female characters}

Many critics have commented on the representation of women in Armah's works. However, these criticisms focus mostly on his later novel Two Thousand Seasons (1973), and they mainly consider the women he represents as what Abena P.A Busia refers to as "Manichean" representations (that is, rigidly divided into good or bad categories), or in roles dependent on the novel's heroes or protagonists (89). Busia, who is the primary critic of images of women in Armah's work, for instance, describes women as being represented as prophets or parasites in five of Armah's novels. Busia's central argument in "Parasites and Prophets: The Use of Women in Ayi Kwei Armah's Novels" is that Armah oscillates between these two images of women. As parasites, they appear as a burden on the soul of the struggling and suffering hero 
and, as liberating prophets, they initiate actions against the invaders and destroyers in Two Thousand Seasons. For Busia, in many of Armah's novels women are also depicted as lovers, wives or blood relatives of "the central male characters, and have significance in the texts only in so far as they affect those characters" (89). She argues that it is only in Two Thousand Seasons that the female figures have roles independent of the hero or the protagonist. In her article, she also states that women are always in secondary roles and they are always unsexed or have chosen to deny their sexuality. However, she does concede that women in Armah's novels "are, in great and small ways, contending with oppression" (52).

Philominah Mintah also categorises the kind of women found in Armah's work into two groups: women of strong character but negative attitudes and strong women who are selfreliant and are refuges or helpers for their men in times of trouble (3). She further states that Two Thousand Seasons highlights women who are strong members of society (4), in charge of affairs of state (5), and have equal status with men (6). Mintah also argues that Two Thousand Seasons (1973) "can be said to be the climax of Armah's feminist inclination" (4) and hence the best illustration of his positive image of Ghanaian women and, by extension, all women. Audrey Gadzekpo calls Armah's women, "deviants” or “archetypes of good or evil" (2). While the women represented in Two Thousand Seasons defy all the odds and restrictions placed on them by traditional society, I argue that the seeds of this kind of empowering and forward-looking representation of women were sown six years earlier in 1968 in his first book, The Beautyful Ones Are Not Yet Born. Furthermore, I argue that there are more pertinent dimensions to Armah's representation of women especially in The Beautyful Ones than previously allowed by critics and that the women represented in Two Thousand Seasons are mythical figures as compared to the more realistically depicted women in the first novel. I suggest that, even in The Beautyful Ones, women are shown in empowering positions. As I further explicate, these characters do not only play a significant 
part in the plot of the stories as indicated by Busia, but are also active participants in the lessons that Armah seeks to teach. Overall, these female characters constitute a fundamental part of Armah's quest to recognise women and the important role they play in Ghanaian society. I argue that for one to fully appreciate how Armah portrays women, one has to study the women he describes in his first novel. This is what I set out to do in this chapter.

Many analysts and commentators did not give a favourable judgment of Armah's The Beautiful Ones. As already noted in Chapter Five, some of these commentators suggested that the author had started his literary life on a wrong trajectory and predicted that he would soon be "extinct" in the African literary scene after only one novel. Notwithstanding these criticisms, Armah continued to make a great impact on literature as he went on to write Fragments (1970), Why Are We So Blest? (1972), Two Thousand Seasons (1973) and four other important works. As a starting point for my analyses of The Beautyful Ones, I will examine the social and cultural roles of Ghanaian women and then will explore how Armah depicts women in his work in terms of these roles and duties.

\subsubsection{Historical and traditional context of representation of women}

Historical evidence gives credence to the significant contribution of women to the socioeconomic development of African societies, and Ghana is no exception. In these traditional societies, the roles of women and men were not clear-cut; there was an overlap in both family and community roles. Duties performed by women were not considered inferior to those carried out by men and vice versa. Hafkin Jone and Hanson Bay put forward the following view of the contributions of women in traditional African society:

Women were treated with unparalleled respect because they were seen to be closer to the creator than men ever had the potential of being. This is because women themselves had the ability to create due to the fact that they were able to give birth. As 
creation [sic] of life, they were charged with the sacred responsibility of caring for the needs of the next generation, and because of this, they can be regarded as the originations [sic] of the idea that is now known as sustainable developments. (59-60) From the above, it is clear that women were seen as embodying a divine nature, due to their reproductive function and their caring for the needs of those around them. Women in particular carried out very important roles in various domains and spheres of the traditional African society. They were considered and revered for representing the moral, cultural and ethical values of the society and were charged with the responsibility of passing on these qualities to the younger generation. In addition, women served in roles such as queens and queen-mothers in some towns and villages in Ghana. In many instances, they participated fully in the decision-making and general leadership roles of their societies, just as the men did.

In the post-independence history of Ghana, there have been frequent attempts by successive governments to effectively incorporate and increase women's representation in policy and decision-making processes and institutions. The success rate of these attempts vary from period to period and from one government to the other. These included an affirmative action programme by Osagyefo Dr Kwame Nkrumah in the early 1960s, which ensured that priority was given to women's participation in male-dominated professions and in public offices. This resulted, for example, in the increase in the number of female parliamentarians from ten in the first parliament of Ghana in 1960, to nineteen in the second parliament in 1965 (Beatrix Allah-Mensah 28, Harvey B. William 36-37).

However, without an appropriate education and access to positions of power, these women could not carry out their duties. As indicated earlier, the nature of education that most of the citizenry had at the time of independence and post-independence was at best clerical. Thus, this education only allowed Ghanaians to fill roles such as stenographer secretaries, 
administrative assistants or special assistants to the colonial administrators (Amamoo, "New Ghana" 15). Rarely would one see Ghanaians trained as architects, engineers or doctors. Worse, the percentage of the population of Ghanaians who were illiterate at the time of independence in 1957 was about 80\% (Amamoo, "New Ghana" 15). As such, it was difficult for the citizenry to have the requisite knowledge to feel sufficiently empowered to confront the establishment; and women were even more disadvantaged since education was even more limited in their case. Sylvia Bawa stresses this fact in her article "Paradoxes of (dis)empowerment in the postcolony: women, culture and social capital in Ghana" arguing that "in global discourses of women's empowerment education is considered the key that unlocks opportunity and empowerment for women, especially in male-dominated societies" (126). Thus, the post-independence woman in Ghana compared to their male counterparts, was in a weaker position due to her lack of education. Nevertheless, certain indications within these periods (pre- and post-independence) point to attempts to improve the presence and impact of women on Ghanaian society. Audrey Gadzekpo states that in the early periods of the Gold Coast (1930s to 1940s), some newspapers offered opportunities for women to submit articles and to publish significant speeches they had delivered. Others occupied editing positions in important newspapers such as the Daily Graphic-for example, Efua Scheck and Dove-Danquah became editors in the 1950s (9).

However, the traditional view of equality between men and women in African society — as separate but equal—did not continue. The equality of roles that existed earlier was severely affected at some point during either the pre-colonial or the pre-independence periods. Views are varied as to when equality ended and when inequality started. Some are of the view that inequality dated back to pre-civilisation and pre-colonisation. Others believe that inequality started with colonisation and still others argue that it came with the advent of wars between the colonies and the colonialists. This last view ties in with the post- 
colonialists' position. While David Owusu-Ansah postulates that the social structure started to change with the Gold Coast's contact with Europeans, Christians and Muslims, as well as colonialism (93), Catherine Cole, on the other hand, indicates that "Christianity and colonialism introduced patrilineal inheritance" (148) into the nation. Miecher F. Stephan in "Making Men in Ghana" also argues that the missionaries introduced patrilineal inheritance (199).

According to Usman Abbas and Füsun Çoban Döşkaya "from the onset of colonization, girls were exempted from attending school because the colonial authorities were only interested in training men for governance and administration" (150). In addition, they affirm that "a different set of subjects were offered for study by either sex" (150). AllahMensah for her part explains that during the period of colonialism "women who had access to the educational system were more likely to study home economics than any other course or subject unrelated to home making" (12). Hence, access to subjects on critical thinking and vital information about the history and politics of the country was left to men. This suggests in effect, a conscious effort on the part of the colonialists to keep women away from relevant experiences that might have empowered them.

The traditional equality between men and women of Ghanaian society was also gradually transformed as wars, tribal disputes and a general change in the socio-cultural landscape occurred over a long period of time. The change in roles was accompanied by a shift in attitudes, reflected in sayings and proverbs, and was also the result of the kind of family systems that were modified because of the conditions outlined above. Below, I briefly explain the types of family that have existed in Ghana. 


\subsubsection{The traditional family structure in Ghana}

The traditional family structure in Ghana encompasses people that are outside the nuclear unit. ${ }^{54}$ Access to vital help and support depends on the kind of kinship that the person has with their family. The traditional family is made up of two main systems, the matrilineal system and the patrilineal system. In the matrilineal type of family structure, one's important family members tend to be those who are related to the mother and in the patrilineal, importance is given to the father's family. These family models affect the kind of inheritance system that families practise and, also, the extent of property ownership among women in these families. They affect the degree of empowerment that women under the two systems enjoy since in a patrilineal system men have the power to determine what happens in the family and in the matrilineal type of family system; females are more likely to hold economic and decision-making power. Therefore, the degree of autonomy that women experience in Ghanaian society is also dependent on the kinship system of their ethnic affiliation and the kind of inheritance that these women can access.

According to Roger Gocking, in Ghana the Akan ethnic group who live around the forest areas of the middle belt to the southern parts of the country mostly practise a matrilineal system of kinship. In this system, membership in the family (abusua), or lineage, is determined through the female line, which means that "property passes from maternal uncles to nephews, as does succession to traditional offices like that of chieftaincy" (8). In simple terms, members of the extended family include a man's mother, his maternal uncles and aunts, his sisters and their children, and his brothers. In this system also, a man's children and those of his brothers belong to the families of their respective mothers. However, within this system, some offices such as the traditional military roles "are inherited patrilineally, as are paternal characteristics (sunsum)" (8). Schneider and Gough affirm that a matrilineal

\footnotetext{
${ }^{54}$ There are, of course, variations in the family structures of the various Ghanaian societies; yet the similarities seem to outweigh these differences.
} 
system of family descent is held to apply "when an individual's initial relationship is to his mother and through her to other kinsmen, both male and female, but continuing only through females" (3). According to them, in patrilineal descent groups, the line of authority and the line of descent both run through men. That means "both authority and group placement are male functions as opposed to matrilineal descent groups where, although the line of authority also runs through men, group placement runs through the line of women" (7). ${ }^{55}$ Cole defines matrilineal inheritance as a system that allows a man's nephew (his sister's son) to inherit from him, adding that "when a man dies, his heir is expected to take responsibility of the wife and children" (148). The patrilineal family in Ghana, according to Elizabeth ArdayfioSchandoff, is made up of “a man's children (male and female), children of his paternal brothers and sisters, his paternal grandfather, the paternal brothers and sisters of his grandfather and, the descendants of his paternal uncle in the direct male line. Therefore, a male parent belongs to the same family as his children; this also means that all of the man's children belong to the same family" (135).

In spite of the matrilineal nature of Akan societies, men hold most traditional leadership positions. However, for a male to take up an inherited position, he has to have a strong connection with his mother or sister. In addition, a man's property is not passed on to his children when he dies, but to his brother or sister's son. According to this system, it is normal for a man to be given the responsibility of supporting the children of a maternal relative, whether this relative is dead or alive.

Armah himself comes from a mixture of the two systems. He recounts: "[M]y mother and my father met when they were quite young. They came from different ethnic backgrounds. My mother's group, Akan, was matrilineal; my father's, Ewe, was patrilineal” (20), a fact which may well have had an impact on his ideas about women and their place in

\footnotetext{
${ }^{55}$ For details on matrilineal societies and how they function in terms of responsibility and inheritance, see Schneider and Gough, Matrilineal Kinship.
} 
Ghanaian society. Armah also had to live with his mother because his parents divorced before he was old enough to start school, after his father took a new wife sent to him by his family: "[T]hey [his father's family] thought he had no right to choose his own wife, marriage being a union of families, not individuals" (20). After the death of the father in 1947, he had to stay with his uncle. He explained the situation thus: "[A]ccording to customary law, my father's children were supposed to go to his brothers, and for several days after the funeral ceremonies, we did in fact live with an uncle in Accra" (31). However, the author of The Beautyful Ones, as we will see, draws on his mixed heritage from both systems, and acts as a mediator in his work by pulling together different attitudes and positions from each system as he represents women in his work. He does not stereotype any woman based on the ethnic affiliation or family descent she comes from and, indeed, the names of the female characters are varied with no attempt to differentiate, distinguish or attribute distinctive tribal features to any of them.

As already indicated, attitudes towards the recognition of women and the role they played in society deteriorated due to wars of liberation and changes in lifestyle. For instance, the British and the Ashanti fought wars in 1823-1826, 1873-1874, 1894-1901 (See Erik Goldstein 139). Fanti and Ashanti fought a war in 1806-1807, while before then, the Fanti fought with neighbouring states from 1700-1726 (See Sanders 362). In particular, due to inter-tribal conflicts and invasions, people were trained to be on guard to protect villages from attacks from rival villages and hence, men had to carry guns and machetes. Certain sayings at this time emphasised mainly how weapons should be handled and who should do so. For instance, these three proverbs from the Akan ethnic group of Ghana put the responsibility of leadership on men: "Even if a woman buys a gun or a drum it is kept in a man's hut," "When a gun is fired, it is the man who receives the bullet in his chest;" and "The hen also knows that it is dawn, but it allows the cock to announce it" (Adomako-Ampofo and 
Boateng 55). Kwesi Yankah reports that certain Akan maxims were indications of the malecenteredness of society. These include sayings such as "Men suffer, women don't know," "Fear women and play with snake" (330). These sayings reflect attitudes adopted against women's leadership, as well as the lack of opportunities for social engagement, participation and even literary representation that forced women into the background, even though their numbers continued to increase in the general population.

Socio-economic power therefore belonged to men, with women-without education - lagging behind in enjoying the rights and privileges of the new nation. When the first post-independence census was held in 1961, out of the over six million people, over 44 percent were women of childbearing age. Owusu-Ansah describes the situation from 1965 onwards thus: "[B]etween 1965 and 1989, a constant 45 percent of the nation's total female population was of childbearing age" (73). According to Owusu-Ansah the female-to-male ratio of the population was high according to 1970 and 1984 figures $-6,063,848$ males to 6,232,233 females (1984), a proportion of 98 males to 100 females (1970) — and this could be "partly attributed to the fact that men have left the country in pursuit of jobs" (73). Thus, women were in fact a majority of the population.

\subsection{Representation of Ghanaian Women in Literature and in The Beautyful Ones}

\subsubsection{Ghanaian women in literature}

In a Report commissioned by the British Council on the "Roles and Representations and Perceptions of Women in Contemporary Ghana" released in 2016, Nana Akua Anyidoho et al., commenting on the representation of women in literature, conclude, "the portrayal of women in Ghanaian creative literature is tied primarily to women's 'ideal' roles as wives and mothers. In addition, one finds frequent representations of women as seductresses and sexual 
commodities and, occasionally, as liberators and advocates for women's emancipation" (15). They cited Abena Busia's article "Parasites and Prophets", stating that "women in Armah's novels never have roles independent of the novel's hero or protagonist—always a man in a male-dominated society. Women are always the lovers, wives, or blood relatives of the central characters" (Busia 89).

Anyidoho et al., further argue that, from Busia's point of view, even though Armah's women during the course of the novels undergo some transformation from parasites to prophets, they become "symbols of liberation and womanhood without a sense of their own individuality and an independent identity" (15). It is significant, however, to point out that even though it appears from the quotation above that Armah somehow represents women negatively, Busia makes a significant point about the nature of the portrayal of women in Armah's work; that is, Armah does not follow all the traditions of negative representations of women:

Armah has broken away from one tradition altogether-he does not subscribe to the convention of the free-spirited harlot; there are no whores in any of his texts, heroic or otherwise. In this he breaks away from a tradition which has existed for several centuries in the west (represented by such well-known characters like Defoe's Moll Flanders, and Dickens' Nancy), and which has also been reflected in the contemporary African novel by such writers as Ekwensi and Ngugi. (106)

Armah chose, as it were, to be isolated from this dominant negative male representation of women, moving to a more progressive one for the women he represented in his work, as his later comments will reveal. 


\subsubsection{Women in Armah's works}

I will now show that the female characters of The Beautyful Ones exemplify the qualities enumerated by Busia and more. In fact, Armah's first novel sows the seeds of the empowering representation of women seen in later novels. In the following section, I will briefly refer to the plot of Armah's second book Fragments and his fourth book Two Thousand Seasons since we will be referring to them as we explore Armah's representation of Ghanaian women. These novels have been considered by critics to be more important than The Beautyful Ones in regard to the representation of women.

Armah's second novel Fragments is set in the late 1960s and it recounts the story of Baako Onipa, a non-typical "been-to" scholar who goes to the USA to study. Before he travels outside Ghana, his uncle Foli performs a ritual of libation. This ritual has the purpose of granting him a safe journey, safe stay, a safe return and being blessed by the ancestors as he returns. However, he returns home to Ghana without the expected riches and glamour that usually mark the return of all those who have been abroad. The book depicts the unpleasant experiences of this scholar during his first year after returning home from America. $\mathrm{He}$ confronts the unbelieving looks and materialistic expectations of his mother, family and the nation at large, as he struggles to comprehend the realities of the materialism that has engulfed the society he had left. Baako Onipa's mistake is that he assumed that upon completion of his studies, when he returns home with his qualification he would gain a decent job. Rather, upon his return, he is confronted with the materialism of his family who have internalised the insatiable desire to acquire wealth ${ }^{56}$ especially foreign goods, and the corrupt values of the government of the day who will not allow him to work without interference. As a result, he resigns his job and starts behaving "abnormally". At the end of the novel, Baako's behaviour is mistaken by his mother as a sign of madness and she takes the decision to send him to an asylum where he finally does go mad. In the midst of this acquired Western

\footnotetext{
${ }^{56}$ This is what Armah refers to in The Beautyful Ones as "the gleam."
} 
materialistic appetite, and in contrast to the controlling and corrupt values of Baako's mother, Armah creates the character of Naana, an old, blind woman who acts as the gate keeper and repository of the culture of the people and who constantly reminds those around her to stick to the old values, such as the pouring of libation and outdooring. ${ }^{57}$

Upon a closer reading of the text of Fragments, one of the minor female characters, Akosua Russel, also appears to be an example of a strong-willed woman. She is also portrayed as having a strong character and being extremely opinionated. This kind of characteristic stands in contrast to the Ghanaian societal expectation of submission and a reserved attitude on the part of women. The representation of this character epitomises the new woman that Armah seeks to develop.

Armah wrote his fourth novel, Two Thousand Seasons (1973) when he was in Tanzania. In it, he exposes the challenges of the communal tragedy of the Ashanti Kingdom that has to transition from its supposed origin in Sudan to slavery as Arabs and Europeans invade it. The invasion was possible because of the failures and wrong choices of the leaders, emanating especially from their selfish desires, egotism and inconsiderateness. The story narrates in the first-person plural, the subsequent struggles for freedom that they undertake and their ultimate relocation and resettlement in modern Ghana, as well as, the arduous task of nation-building and reconstruction that faces them. The "we-narrator", represented in the traditional griot fashion, emphasises the need to go back to "the way", which is an idealised past way of life. This is seen as the solution to the problems of the newly acquired egoistical way of life of the leaders which has replaced the previous communal way of life that put the community before the individual. The feminine characters of this book include Abena who is

\footnotetext{
${ }^{57}$ The outdooring ceremony in the traditional context is very significant. It marks the entry of the child into the physical world. The child is not considered integrated into the material world after its birth until after a certain period of time has elapsed - a minimum of seven days - when both mother and child are welcomed at an early morning ceremony, with relatives, friends and families, and the baby is given a name. Performed too soon, as happens in the novel, the child might die and it would be considered that the spirits had taken him away: "[T]he child is not yet with us. He is in the keeping of the spirits still" (Armah 138).
} 
brave and virtuous; Anoa, a prophet who predicts what will happen to her society; Ajoa, who nurses Araba Jesiwa, the mother of the murdered prince and Densu; and Nana Esi Amanyiwa, who is the grandmother of the murdered prince Appia. These women appear in various sections of the novel and they replicate various roles - mother, sister, wife - as seen in their precursors in Armah's first novel.

\subsubsection{Women in The Beautyful Ones}

In my reading of The Beautyful Ones, I argue that Armah attaches a special value to women in his work. For Busia, even though the women in all of Armah's work are seen to be playing subordinate roles with respect to the men they are connected with, in his later novels women finally end up being the redeeming prophets of these relationships (Busia 89). However, even in the representations of the female characters in his first work, I argue, women are depicted as initiators of actions, moral and emotional supporters of their men, sources of knowledge and as prophets and, even more, as those who understand more completely the economic and social situation in which they live.

\subsubsection{Women as initiators of actions}

The female characters of Armah's work are portrayed as the initiators of actions. In the setting of The Beautyful Ones, even though these functions are somehow eclipsed by the suggestions and opinions of their male counterparts, they are often the source of new ideas. Oyo, for instance, constantly asks her husband, The Man, to put in place measures that will help improve their living conditions. Firstly, she asks her husband to try to live like other people so that their situation will improve and eventually prosperity will be enjoyed by the family. She aspires to follow the example of Koomson's wife, Estella, living well and wearing good perfumes, according to the standards of those seeking after "the gleam". When 
she realises that her husband does not desire to live like the rest of his friends and especially his former schoolmate Koomson, Oyo reprimands The Man, "you refused [the bribe]? When you shook Estella Koomson's hand, was not the perfume that stayed on yours a pleasing thing? Maybe you like this crawling that we do, but I am tired of it. I would like to have someone drive me where I want to go" (Armah 51). Oyo's posture leads Busia to conclude that she makes demands, which are "generally material ones concerned with keeping up social appearances" (90). But upon a careful study of the text, one realises that, in fact, she is seeking a better life for the family and not necessarily the corruption of the gleam. She just wants to enjoy a little respite from poverty. She declares to her husband, after stating that she is tired of the crawling, asking "why not? Is she more than I?" (51), and clearly states her motives after this declaration, saying " $[\mathrm{I}] \mathrm{s}$ there anything wrong with some entertainment now and then?" (52).

In another instance, Oyo, as the initiator, informs her husband that it is possible to sign a fishing boat deal with Koomson in order to have both a source of income and a source of food (protein) for the family. Even though she doubts that her husband in his political rectitude will support the deal (which is fraudulent), she suggests it anyway and takes the initiative to arrange for a visit to Koomson's house to discuss it. The decision to invite Koomson on a visit to their home is also Oyo's proposal. Even more importantly, as we will see at the end of the novel, The Man's wife initiates the conversation that proves to The Man that he has not erred in sticking to his decision to be morally upright and not to succumb to the decaying morals around him at his work place.

Another woman-initiator in the novel is Maanan. When the male characters, The Man, Etse, and their friends grow tired of all the political rhetoric and campaign messages that do not yield anything, she brings a new hope to them. She motivates them to go and listen to the one she calls the "new man" who has a different message for them as The Man recounts here: 
"[W]e knew there was to be a rally at Asamansudo, but we had stopped going long before" (98). It is she who convinces them to attend the rally. Maanan serves as the initiator of most of the political debates that they have as a group of friends, pointing out issues of concern and importance to them for their consideration. Even in their rounds of sharing pot ("wee"), Maanan is again the initiator of the activity: "Maanan brought it, and showed us how to light it and to smoke it, one of us dragging at a time" (82). The Man indicates that most people are afraid to smoke the pot: "[Y]ou must know there is at least this much that could frighten

uncertain men away from wee..." (82), but Maanan is not frightened. The importance of these wee smoking meetings lies in their frequency and the intimacy they share, and the philosophical discussions they often have at these times: "[W]ee can make you see things that you might perhaps not really want to see" (82). And Maanan is an integral part of that process.

\subsubsection{Women as emotional and moral supporters}

Maanan, Oyo and The Man's mother-in-law play the role of moral and emotional support for their friends, husbands and family. The Man's mother-in-law is on many occasions the backbone of his family - she takes care of the children any time The Man and his wife have to go out. She serves as the social, emotional and moral support for the children, and for her daughter, Oyo. In times when the latter needs her support and advice as to how to handle her domestic issues, she is available to help.

Oyo plays an important role as a support for the husband in the novel. The first time The Man's wife was mentioned in the narrative was on page 48 and she was mentioned in a favourable light. She was introduced to us on a positive note as she was described as a "waiting wife". The narrator explains thus: "The Man walks into the hall, meeting the eyes of his waiting wife". This description is significant in the sense that, despite all the challenges in 
their life and in their marriage, she still discharges her duty as a wife to The Man. The gerund indicates this gesture is habitually what she does. Even though she has every right to rebuke The Man and make him uncomfortable, she keeps quiet and welcomes him home and this attitude could only make The Man grateful for her forbearance: "The man feels a certain tired gratitude; he is thankful there are no words to lance the tension of the silence" (49). The other gratitude he feels and which he again expresses silently to himself is the fact that there was food on the table for him to eat when he came back from work. Oyo always has food ready for the husband to come home to-a very important component of the socio-cultural life of Ghanaians. Ghanaian customs of hospitality demand that the courtesy of food and water be extended to visitors to homes, even if there is little friendship between the visitor and the household s/he is visiting. This courtesy is also extended to any member of the family who has been away from home for a long time. Despite the flat look on Oyo's face, showing her discontent and displeasure at the economic situation of the family, she prepares food for The Man: "The Man moves forward and sits at it (the table that has food on it) with his back to his guilt (49). Oyo also welcomes her husband with a smile (even on those days when they had disagreements before he left) and she always tells him about the events of the day with the children. She updates the husband on the day-to-day issues affecting the children, how they are growing up, their thoughts about things and their progress at school.

Even though the reader sees them struggling economically and finding it difficult to maintain a smooth communication devoid of arguments, there are also scenes of evident affection. In addition, in spite of Oyo's seemingly intense desire to be like other people who live well and her vehement rebukes of her husband, it is clear that she has a deep affection for The Man. She has borne three children for him and in the process, her body has been scarred but she is still sensitive and conscious about not reminding The Man of the scar since she knows it makes him feel guilty. One day after bathing, she asks The Man to hurry up with his 
dressing so she could also dress, and when he was delaying the process she asked, "You are taking a long time", "have you become a leper? ... I just thought you'd get out and let me dress" And when The Man asked flirtatiously, "Ashamed to be seen by lecherous strangers, Oyo?" she replied: “Ah, look at it if you want to. It's you who will lose your appetite for it, not me." After these words, "she smiled ... she let her cloth fall and he could see her flabby belly with the scar on it" (150). The narrator explains how the Man felt after watching Oyo drop her cloth: "Every time he saw it it looked bigger than he thought it should be" (150) and he left the room immediately. By hiding the scar, Oyo shows compassion and care towards her husband. Earlier on, the narrator makes us aware of the fact that the Man and the wife, Oyo sometimes share caring or loving moments: the day the third child was born via a caesarean section, for example, "there was love in her" (116). In addition, the narrator explains that The Man also had love for her: "[T]here had always been [love], of course since he had never had anything else he could have given her" (116).

By way of contrast to Guillén's women, Armah's woman is not the beautiful, exotic Afro-Cuban dancer or the Queenly African woman; she is rather a woman who has been scarred by life and childbirth. Therefore, she has struggled like Guillén's women but does not embody the same kind of physical beauty. Both see women as an important and integral part of society, and as having to struggle in the world but the circumstances are quite different.

Oyo exhibits passion and compassion towards The Man at the same time. Even though she is always vehemently pushing him to go out there and be the best-bring home material goods - it is all for the benefit of the family. Oyo's show of love to The Man is twoedged - sometimes sweet and bitter at other times. In this ambivalent situation, The Man ends up each day feeling a kind of uneasiness and sorrow due mainly to his inability to provide the daily needs and meet the demands of his wife. This uneasiness also produces his daily feelings of lack of fulfilment and self-actualisation, as he doubts each day whether he is 
making Oyo happy. Oyo, therefore, is central to the emotional life of The Man. A high point in her supporting role as a support is also seen in the final stage of the novel when she holds The Man's hand and declares that she is happy that he has not behaved like the corrupt ministers, politicians and workers (194).

Maanan's role as a support for The Man, Kofi Billy and Etse is clearly seen in the conversations she shares with them. She acts as a social and emotional support for her friends, leading The Man to appreciate the emotions that people can experience when they are in the company of genuine friends. She asks question that make them think about life, and as The Man indicates: "Maanan ... with a smile in her voice told us both to wait till we could tell ourselves the truth" (82-3). Busia views this as Maanan teaching her friends the meaning of loving and communal unity (92). Through her dialogues with them, they appreciate the pain that can arise out of disappointments and betrayals by friends, as Maanan experienced them. The Man reflects upon how he met Maanan and Etse, and reminiscences about the stories they shared together as they supported and enjoyed each other's company and the guilt he felt for not supporting Maanan: "[S]he was smiling at me, but in myself I felt accused by a silence that belonged to millions and ages of women all bearing the face and the form of Maanan, and needing no voice at all to tell me I had failed them, ..." (Armah, Beautyful Ones 85). Although The Man feels a burden of guilt as he ponders what has happened to Maanan, and also his wife, he could not do anything about it other than to hold them in his memories with respect.

\subsubsection{Women as prophets and sources of knowledge}

Another role played by the three main female characters in The Beautiful Ones is that of a socio-economic prophet. Busia sees them as prophets who predict the future of the situation in which they find themselves but, in my opinion, this role is extended to include 
understanding the socio-economic times and seasons of post-independence Ghana. In this role, Oyo is constantly pushing her husband to imagine a good future, to envisage a life that is better than the situation they have currently. Even though she could be considered as not calculating the moral cost of the kind of lifestyle she is demanding from the husband in her anger, she means well for the family. Maanan, on the other hand, predicts a good future for the nation. She anticipates that the new man will be the key to the changes that they have been hoping for: "He is new, and he is young. He is one of us all right. Only nobody knows much about him. They say he does not go talking about himself. Only the work we have to do" (Armah 98). I concur with Busia when she declares, "importantly, as we move through Armah's work sequentially, the prophets eclipse the parasites" (89), but I assert that the female characters are socio-economic prophets even in this early novel. While in Two Thousand Seasons these women were portrayed as mystical prophets, those in The Beautyful Ones are more realistic. Being designated a prophet is very significant in the Ghanaian context. It implies that socio-culturally and politically, the women assume the role of the spokesperson for their society and community.

Armah represents women as a source of knowledge. Women often act as educators in his novels. Before talking about Oyo and the mother and Maanan especially, it is crucial to make reference to Fragments. In this work, Naana, the elderly blind woman referred to earlier, is held to be the custodian of knowledge, both ancestral wisdom and the day-to-day knowledge of how society should function. She is the embodiment of the customs and the traditions of her society, making sure when the libation for a safe trip for Baako was being poured, that all proper procedures were followed. In The Beautyful Ones, Oyo and her mother also act as the store of knowledge for the family. They know the times of hardship and the seasons of abundance and demand from The Man that he acts upon this knowledge, even though these times and seasons are mostly propitious for corrupt practices. As sources, 
custodians and repositories of knowledge, and as educators, these women ask The Man very poignant questions that make him reflect on his life. In one of their interactions, The Man realises that his wife Oyo thinks through issues deeply before suggesting them, even though sometimes the suggestions are influenced by the desire to satisfy the more material needs of the household. He narrates the events of the day and complains to his friend, the teacher about the depth of his wife's thinking, which in turn causes him to think even more. He states:

My wife explained to me, step by step, that life was like a lot of roads: long roads, short roads, wide and narrow, steep and level, all sorts of roads ... that human beings were like so many people driving their cars on all these roads ... that those who wanted to get far had to learn to drive fast ... Accidents would happen ... but the fear of accidents would never keep men from driving. (68)

Most of the decisions he takes in order not to participate in the corruption and the decay around him are as a result of the pressure of questions and counter-arguments that come from Oyo. With the chichidodo incident, The Man has no other option than to reflect on what the wife says and decide whether he wants to continue being the only individual who will not receive the bribes and enticements that come with the public office that he occupies. Indeed, at the end of the novel, Oyo, having seen the light, congratulates him for persisting in his efforts to remain sane and untainted by the "dirt" of the land: "[S]he held his hand in a tight grasp. Then, in a voice that sounded as if she were choking, she whispered, "I am glad you never became like him" (Armah 194).

Elsewhere, in the novel, Armah depicts Maanan's character as an avid reader, an educator and a storehouse of knowledge. She argues her political opinions and views cogently and convincingly. When The Man and his friends can no longer believe in politics and politicians and will not attend any political rally, Maanan's knowledge of the political 
landscape of the time and her cogent arguments are what convince them to attend the rally organised by the new man. Indeed, even in their private interactions and day-to-day dealings, it is Maanan who always educates them-including by supplying the "wee" they smoke together.

\subsubsection{Women in the family (Wives and Sisters)}

Women are portrayed in significant societal roles such as wives and sisters. In the majority of Ghanaian societies discussed already, especially among those in the southern part of Ghana, the place of wives and sisters is very significant, especially when it comes to the type of inheritance that a family practices and the responsibilities that go with it. Busia sees these positions of women as "normal" roles (89), ones that most writers give to women. However, from the text of The Beautyful Ones, the reader or the audience appreciates how Armah underscores the relevance of these roles as the third-person narrator refers to Oyo as The Man's wife $(48,49)$ and introduces Maanan as "Sister Maanan" (77). In the traditional Akan setting in Ghana, to be referred to as a wife (pre- and post-independence Ghanaian society), is of immense significance - this woman has the potential of being the Queen Mother, the Mother of the chief (the traditional ruler) or the one who elects the next chief. In addition, being the sister of a wealthy brother in the Akan setting, for example, means positioning one's children to access the wealth and the goodwill of one's brother. Again, in referring to Maanan as "sister," Armah emphasises the role that she played in the life of The Man and his friends. The Man declares, “[W]e followed Maanan as if she had been our mother, Kofi Billy and myself," thus emphasising the leadership role that she played in the life of these friends, in addition to her role as the initiator of action and as a source of love and community. These references (wife, sister and mother), I argue, are significant pointers that these women are 
important figures and deserve respect in the male-dominated society of Ghana. This is what Armah reflects in his novel.

The only woman portrayed in an unremittingly negative way in the novel is Koomson's wife, Estella. She is presented to us as having assimilated the dominant ideology of "learning to drive fast" and, in so doing, participates together with her husband, in the decay and corruption of the society. She flagrantly displays her wealth and never thinks about those who have voted her husband and others like him into political positions. Her insensitivity and her appetite for luxury and foreign goods betray her as a very superficial and materialistic woman and hence a negative character, unlike the rest of the women in the novel who also have materialistic desires but do not show obsessive behaviour in relation to material goods as she does. Even so, Armah attempts to portray Estella as one who acts as a support to her husband, accompanying him wherever he goes and backing all his decisions.

\subsection{Conclusion}

Clearly, Oyo, her mother, and Maanan emerge as strong characters in Armah's story about the post-independence society of Ghana. The initial images of the women remain largely the same until the end of the novel: The Man's mother-in-law still has her judgemental and negative opinions about The Man, but is also, still motivated by the love for her daughter and her grandchildren to stick together with the family; Maanan does not change her mind about her friendship with the Etse, Kofi Billy and The Man, despite the political disillusionment that eventually drives her mad. Oyo, however, does evolve from the initial desire to follow the gleam to a position more aligned with that of her husband. She now has a different understanding of the general socio-economic situation of the country and she is happy her 
husband is not part of the corruption and fallout of the coup d'état, and continues in her role as a support for the husband.

In a video interview in 2016, Armah confirms the nature of women he characterises in his work. He acknowledges the difficulties women have to face just because they are women. The example he gives is of women and child bearing. To him, for women to be able to carry a baby in their bodies for nine months shows the kind of capacity for endurance they have. He confesses that he could not bear the sort of burden they carry. Armah states his conviction about women in general and about those that appear in his work and by extension, women in Ghanaian society thus:

They [women] make up more than half of the population of the world and they do more than half of the work of the world. You have to be strong to be able to do that. I look at the women around me; many of them carry enormous burdens. I have no idea how much strength it would take for me to be able to do something like having a baby from my body. (“Conversations with Dr Armah”)

Based on this appreciation of the strength and capacity of women, he states that the kind of women he seeks to create in his works are those of strong character. These women are able to withstand the dictates of the male-dominated society of Ghana and remain sane- 'I don't think my drawing of them as strong people in my work is an exaggeration" ("Conversations"). He further extols the work women do in society and the need for them to be recognised:

So, when I write about women, I have in my mind the fact that they as a group are doing fantastic work for all society, but at the same time, I see that women have been underrated and undervalued. If in my work I can give credit where it is due, I will do that. I don't think any society can be whole when it is entirely run by men. The 
importance I give to women in my work is only what I think they deserve. (“Conversations")

It is clear from his statements that Armah recognises the value of women to society. He again recognises the strength of women as the source of life, the ultimate channel through which humanity comes into being and is sustained. More importantly, our writer appreciates the underrated and unappreciated position that women have to occupy just for the sake of being women and he does the needful thing- "giving credit where it is due." In his fictional world, and, by extension, in real society, he portrays them as having valuable traits. As such, women like Akosua Russel in Fragments or Maanan in The Beautyful Ones are created as strong women who can face the challenges of society. Even though Busia calls these women characters "parasites" or "liberating prophets" (89), the mere fact that Armah has chosen to represent them positively and realistically or portray them in roles that were unorthodox for Ghanaian women in The Beautyful Ones, is very important in the literary landscape of Ghana. As Leif Lorentzon, the African literary critic, indicates, “many critics have observed Armah's (for a male African writer) unusually sensitive portrayal of women - even if the critics are not in complete agreement regarding the merit of these portrayals" (230). This commentary on Armah's work, from one of the leading critics of Ghanaian and African literature, also validates the author's positive and progressive approach to the representation of women since most writers in the 1960s — both men and women — concentrate their efforts on portraying the masculine part of society, relegating women to the background.

From this discussion, then, we get the sense that Armah undoubtedly has a particular view as to the kind of post-independence Ghanaian women he depicts in his work. In The Beautyful Ones, through careful observation of the women around him and of the situation of women in general, he portrays a positive view of women-while neither perfect nor mythical beings, they are sources of wisdom, fountains of life, support and sustenance. These women 
are also depicted as having the strong will that is necessary to survive in the hostile maledominated African society of Ghana. He makes a conscious effort among his peers to be a beacon of hope for women as he rightly said, "I am sure that I am not always successful in presenting women honourably but I try" ("Conversations"). The critical ingredient here is the confession that he attempts what other African male writers do not. It is clear that the characters of these women depicted in this novel are endowed with the capacity to be symbols for other women to aspire to in the society.

In conclusion, these depictions of women in The Beautyful Ones hint at the empowering positions which he develops in his later novels. But, above all, the women represented in The Beautyful Ones are women like those found in real life, in real society and are women with the day-to-day flaws of human beings. These women live out the fears and anxieties that a post-independence society brings, where everything is at an embryonic stage of development. For them to be able to play the roles assigned to them, they must have exceptional qualities to be able to traverse the difficult terrain of post-independence life in Ghana. Their depiction parallels the first kind of women represented in Guillén's first collection of poems - women with special stamina, shown in their day-to-day situations and interactions with the Black men they relate with, hardworking and seeking to improve their economic conditions. Their second portrayal - mythical and supernatural women - as seen in Two Thousands Seasons matches Guillén's later representations of Black women in the poem "Mujer Nueva." 


\section{CONCLUSION}

In this thesis, I have argued that the works of Ayi Kwei Armah and Nicolás Guillén can be productively compared, as there is a fundamental common denominator connecting these two writers: they are both engaged post-colonial writers who are not content with the outcomes of the independence project of their nations and the societies that have resulted. In their works, they are therefore searching for and proposing solutions that will in the long-run redefine aspects of their society after independence.

Armah and Guillén's dissatisfaction with the independence experiment of their countries is directed towards varied issues and the solutions they proffer take distinct but similar paths. Armah's discontent is directed towards the corruption and mismanagement that engulfed the political elites; in particular, he shows how this corruption is reflected in the lives of the lowly-placed in society. The gravity of the situation is viscerally registered in The Beautyful Ones Are Not Yet Born where the stench of corruption and decay is perceived by the senses as we read the work: corruption and bribery have become part of day-to-day lives of Ghanaians at the time of the novel. The poor, women and children carry the burden of this situation, as they struggle to survive. Guillén's indignation, on the other hand, is directed forcefully at the inequality and hierarchy that was created in Cuban society by historical phenomena like blanqueamiento, which encouraged Blacks to reject their race and seek to become "whiter" through interbreeding or mestizaje, and the official Cuban rhetoric of racelessness and racial discrimination. Although the Constitution of Cuba, the supreme document of the nation, had provisions that encouraged Blacks and Whites to live together in equality, unity, peace and dignity, what in fact eventuated from independence was the denial of opportunities for Blacks, racist attitudes towards them and, in the case of women, the unpalatable depiction of Black women as animalistic sexual objects and as people without worth. 
Guillén's response to the situation of his country in his writing is seen in his highlighting of Blackness in his works Motivos de son and Songoro Cosongo, and his emphasis on the relevance, value and uniqueness of Blackness to Cuban society. In the midst of the official rhetoric of racelessness, the silence on the discrimination, maltreatment and lack of opportunities that Blacks faced, and the many White and mulatto writers who manifested this silence in their writings, Guillén demonstrates a determination to uncover the truth of these issues. He focuses on racial inequality, highlights the extent of discrimination against Blacks; and, at the same time, brings attention to the importance of Blackness in the life of the nation of Cuba. He also asserts the authority of Black culture.

The study also underscores the importance to Guillén of collaboration and cooperation between the two races of the island of Cuba. I conclude that to achieve this desired outcome of "dos en dos"- the two races working together-Guillén sought to bridge the gap between Blacks and Whites in his poetry. More importantly, the thesis stresses the values of the Afro-Cuban son as the only authentic voice to which both Blacks and Whites respond and, by extension, Black culture and its authority over Blacks and Whites and its power to unite both races for social, economic and political development of the nation is asserted. Through the analysis of the poems selected for this study, I have shown that for Guillén, Blackness and Black culture is crucial to the future harmony of Cuban society since it is a powerful unifying factor for all Cubans.

One of the principal contributions of this thesis is the critical analysis of the prologue to Sóngoro cosongo, which had been glossed over by many critics as mainly pointing to the mestizo nature of Guillén's poems. In my analysis, I argue that the various metaphors that Guillén uses for the nation of Cuba in the prologue in fact assert the uniqueness of the two races, the complex and complicated waterways of blood vessels and capillaries working independently but together, and the strong connections or bonds between Blacks and Whites. 
Even though they are mixed and connected, these two races are not merged in the process. Thus, I argue, Guillén is not a poet of mestizaje but rather a poet of interconnectedness.

Further, even though he has been criticised by Vera Kutzinski for his machista, unproductive and male chauvinistic depiction of Black women as in his work from the 1920s and 1930s, this study, rather, reveals that Guillén's representation of women in Motivos de son shows a sustained effort to depict Black women in a more positive manner than has been allowed. I have shown that Guillén re-shapes the dominant unproductive representations of these Black women into more assertive, progressive and empowering images of them and draws Cuban society's attention to what they represent and what they are worth. That is, he re-values aspects of the Black woman stereotype such as their black colour and their physicality, which have been denigrated and gives them a positive focus.

I have also offered a fresh perspective on the negative critical response to the emphasis on corruption and disgust in Armah's first work The Beautyful Ones are Not Yet Born. Only one critic, Minna Johanna Niemi, has treated the focus on national decay positively. Niemi points to the theme of an individual's ethical choice that opens up a way towards a better communal future. Other than Niemi, all the critics have read the preoccupation of his work with dirt as revealing an extremely negative vision of Ghana, of which they do not approve. While not wishing to downplay the degree of dirt and corruption depicted in the novel, I propose a different reading of Armah's first novel. My reading places Armah's first novel in a more regenerative and positive light. I show that as a response to the state of affairs of the nation of Ghana after independence, Armah's novel sets out, the reality of the situation which becomes the context for that new birth that will eventually lead to regrowth and development.

As an "engaged writer" whose responsibility resides in his being able to articulate both the pleasant and the unpleasant aspects of his society, he exhibits an earnest 
determination to provide a solution to the challenges of his society. As a social physician, Armah kept his creative stethoscope close to the heartbeat and pulse of the society of Ghana, diagnosing its problems, and proposing solutions in the form of an upright and moral character. I have argued that Armah sets out his vision of regeneration and regrowth for Ghanaian society through the main protagonist of the novel, The Man. He presents him as a symbol of fundamental African and Ghanaian traditional cultural values of honesty, truth and family cohesion which are essential factors in the rebuilding process of society after independence. The study concludes that for Armah, the protagonist and the characteristics he models foreshadow the "beautiful ones" that Armah envisages will be born at some point in the future to facilitate Ghana's passage to good governance for all its citizens. The Man also embodies the "ideals" of the national traits that Armah believes are necessary for "redevelopment" of the Ghanaian nation after independence.

Armah's novel hints at the possibility of changing the bleak and decaying moral fibre of society to a more productive one. Armah's hope for the nation is indicated in the glimpses of "clear water", "the stream", “clearness", and "quiet attraction"—all enhanced by Armah's repeated use of the words "peace" and "purity". Through exploring and applying concepts such as sankofa and the engaged writer, I have shown that in fact Armah's The Beautyful Ones Are Not Yet Born carries a message of hope of reconstruction through traditional values for Ghana, a country that has been ravaged by corruption and moral disintegration in the aftermath of independence.

As a solution to the undervaluing and inadequate representation of women in Ghana, Armah extends the limited roles given to women in post-independence Ghanaian society to more empowering ones. He does not only represent them as wives and as supporters (moral and emotional) of their men but, more importantly, as initiators of actions - decision takersas a source, custodians, and repositories of knowledge for their family and the society. In 
addition, he represents them as educators, as well as providers of social support for the men they live with.

One of the main contributions of this thesis to the scholarship on Armah in general and to the independence history of Ghana is that the project analyses the society depicted in the novel at different levels; the national, local and individual levels (The Man himself and his day-to-day relationships). It shows that these levels parallel those of the postindependence Ghanaian society in terms of the inequalities and class stratifications that arose because of the inefficiencies in the independence project when the "sons of the nation" took over power. With these categorisations, the thesis examined Armah's work as a retelling of a critical part of social and political history of Ghana as it details the characteristics, values, hopes and aspirations of the various categories.

Overall, the thesis identified the fact that Armah and Guillén searched for a distinctive social and cultural identity for their two nations, notwithstanding the disillusionments after independence. This search was also within a specific period and within a historical context. The thesis offers prospects for future research into Afro-Cuban and Afro-Ghanaian literature because themes relating to, but not limited to, the post-independence period and sociocultural lives of these nations could be further explored. One line of future inquiry could be the exploration of the working of the "dos en dos" principle in both Ghanaian and Cuban literature, especially as it could be related to three Akan adinkra symbols of "bi nka bi" (no one should bite the other), "ese ne tekrema" (the teeth and the tongue living together) and "akoma ntoso (linked hearts). These symbols encapsulate and deepen the understanding of the concept of "brother"- - discussed in this thesis - in Ghanaian culture. In addition, there is scope for further research into the working of the concept of the "engaged writer" in Armah's second book, Fragments, and Guillén's third collection of poetry, West Indies Ltd. 
For all the disappointments of independence that both writers anatomise unflinchingly, there are signs everywhere in the lives of the people betrayed by their leaders of resilience and hopefulness. In the memories of the past, however broken in practice, both Armah and Guillén find the sources of regeneration. 


\section{WORKS CITED}

\section{Primary Sources}

Abass, Usman, and Füsun Çoban-Döşkaya. "The Position of Women in the Social and Political History of Ghana." Türk Dünyası Incelemeleri Dergisi/Journal of Turkish World Studies, vol. 17, no. 2, Winter 2017, pp. 141-62.

Abreu, Christina D. Rhythms of Race: Cuban Musicians and the Making of Latino New York City and Miami. 1940-1960. U of North Carolina P, 2015.

Achebe, Chinua. "Africa and her Writers." Morning Yet on Creation Day: Essays, Heinemann, 1975, pp.19-29.

African, Caribbean, and Pacific Group of States. www.acp.int/content/secretariat-acp

Adomako Ampofo, Akosua, and John Boateng. "Multiple Meanings of Manhood among Boys in Ghana." From Boys to Men: Social Constructions of Masculinity in Contemporary Society, edited by Tamara Shefer, Kopano Ratele, Anna Strebel, Nokuthula Shabalala and Rosemarie Buikema, U Cape Town P, 2007, pp. 50-74.

Agbodeka, Francis. "The Fanti Confederacy 1865-69: An Enquiry into the Origins, Nature and Extent of an Early West African Protest Movement." Transactions of the Historical Society of Ghana, vol. 7. Broadview Press, 1964, pp. 82-123.

Aguirre, Mirta C. “Discurso.” Revolución y cultura, vol. 25, 1974, pp. 46-49.

Aidoo, Ama Ata. Introduction. The Beautyful Ones Are Not Yet Born, Collier Macmillan, 1969, pp. x-xii. 
---."No Saviours." African Writers on African Writing, edited by G. D. Killam, Heinemann, 1973, pp. 14-18.

Akombo, David. The Unity of Music and Dance in World Cultures. McFarland and Company, 2015.

Allah-Mensah, Beatrix. Women in Politics and Public Life in Ghana. Friedrich Ebert Foundation (FES), 2005.

Allen, Jafari S. ;Venceremos?: The Erotics of Black Self-making in Cuba. Duke UP, 2011.

Amamoo, Joseph. The New Ghana: The Birth of a Nation. Authors Choice Press, 1958.

---. The Ghanaian Revolution. Authors Choice Press, 1989.

Amuta, Chidi. "Ayi Kwei Armah and the Mythopoesis of Mental Decolonisation." Ufahamu, vol. 10, no. 3, 1981, pp. 49-50.

Anyidoho, Kofi. "National Identity and the Language of Metaphor." FonTomFrom: Contemporary Ghanaian Literature, Theatre and Film. Matatu (numbers 21-22), edited by Kofi Anyidoho and James Gibbs, Rodopi, 2000, pp. 1-22.

Anyidoho, Nana Akua, et al. "Shakespeare Lives in Ghana: Roles, Representations and Perceptions of Women in Contemporary Ghana.” April 2016, pp.1-54.

www.britishcouncil.org.gh/sites/default/files/shakespeare lives women in contempo rary_ghana_final_report_4_april.pdf

Anzoútegui, Victor Tau. "Provincial and Local Laws of the Indies." New Horizons in Spanish Colonial Law: Contributions to Transnational Early Modern Legal History, edited by Thomas Duve and Heikki Pihlajamäki. Max Planck Institute for European Legal History, 2015, pp. 235-55. 
Appiah, Kwame, and Henry L Gates Jr, editors. Africana: The Encyclopaedia of the African and African-American Experience. Civitas Books, 1999.

Ardayfio-Schandorf, Elizabeth. "The Family in Ghana: Past and Present Perspectives." African Families at the Turn of the 21st Century, edited by Yaw Oheneba-Sakyi, Baffour K. Takyi, Praeger, 2006, pp. 129-52.

Armah, Ayi Kwei. The Beautiful Ones Are Not yet Born. Heinemann/William Clowes and Sons 1968.

---. Fragments. Houghton Mifflin, 1970.

---. Two Thousand Seasons. Heinemann, 1973.

---. "Masks and Marx: The Marxist Ethos vis-à-vis African Revolutionary Theory and Praxis.” Présence Africaine, no.131, 1984, pp. 49-65.

---. KMT: In The House of Life. Per Ankh, The African Publishing Cooperative, 2002.

---. Osiris Rising: A Novel of Africa Past, Present, and Future. Per Ankh, 1995.

---. The Eloquence of the Scribes: A Memoir on the Sources and Resources of African Literature. Per Ankh, 2006.

Arnedo-Gómez, Miguel. Writing Rumba: The Afrocubanista Movement in Poetry. U of Virginia P, 2006.

---. Uniting Blacks in a Raceless Nation: Blackness, Afro-Cuban Culture, and Mestizaje in the Prose and Poetry of Nicolás Guillén. Bucknell UP, 2016.

Asihene, Ernest V. Understanding the Traditional Art of Ghana. Fairleigh Dickson UP, 1978. 
Augier, Ángel, and Joseph M Bernstein "The Cuban Poetry of Nicolas Guillen.” Phylon (1940-1956), vol. 12, no. 1, 1951, pp. 29-36.

---. Nicolás Guillén. Notas para un estudio biográfico-crítico, Tomo II. Editora del Consejo Nacional de Universidades, 1964.

Azindow, Yakubu M. Philosophical Reflections of Adinkra Symbols. Indiana UP, 1999.

Badiane, Mamadou. The Changing Face of Afro-Caribbean Cultural Identity: Negrismo and Négritude. Lexington Books, 2010.

Barrow, Christine. Caribbean Portraits: Essays on Gender Ideologies and Identities. Ian Randle Publishers, 1998.

Bastian, Allis Jeanette. Owning Memory: How a Caribbean Community Lost its Archives and Found its History. Libraries Unlimited, 2003.

Bawa, Sylvia. "Paradoxes of (Dis)Empowerment in the Postcolony: Women, Culture and Social Capital in Ghana.” Third World Quarterly, vol. 37, no. 1, 2016, pp. 119-35.

Beckles, Hilary. Centring Woman: Gender Discourses in Caribbean Slave Society. Ian Randle Publishers, 1999.

Benítez Rojo, Antonio. "Ideología y literatura: la novela antiesclavista en Cuba, 1835-1839." Cuadernos Hispanoamericanos, no. 451/52, 1988, pp. 169-86.

Benjamin-Robert, Jules. The United States and Cuba: Hegemony and Dependent Development, 1880-1934. U of Pittsburgh P, 1974.

Bethell, Leslie. Cuba: A Short History. Cambridge UP, 1993.

Biney, Ama. The Political and Social Thought of Kwame Nkrumah. Palgrave Macmillan, 2011. 
Boafo-Arthur, Kwame. "Longitudinal View on Ghana's Parliamentary Practices." African Parliaments: Between Governance and Government, edited by M.A. Mohamed Salih, Palgrave MacMillan, 2005, pp. 120-41.

Bourret, F.M. Ghana, the Road to Independence. Oxford UP, 1960.

Branche, Jerome. Colonialism and Race in Luso-Hispanic Literature. U of Missouri P, 2006.

Briggs, Philip. Ghana. Globe Pequot Press, 2014.

Bronfman, Alejandra. Measures of Equality. Social Science, Citizenship and Race in Cuba, 1902-1940. The U of North Carolina P, 2004.

Burch, Wanda E. She Who Dreams: A Journey into Healing through Dreamwork. New World Library, 2003.

Busia, Abena P. A. "Parasites and Prophets: The Use of Women in Ayi Kwei Armah's Novels." Ngambika: Studies of Women in African literature, edited by Carole Boyce Harper and Anne Adams Graves, Africa World, 1986, pp. 89-113.

Cabrera, Raimundo. Cuba and the Cubans. The Levytype Company, 1896.

Cairo Ballester, Ana. Nicolás Guillén and the Debates on Mulatto Culture. Translated by Katerina González Seligmann. The CLR James Journal, vol. 21, issue 1/2, (Fall 2015), pp. 69-89.

Clark, Mary Ann. Then We'll Sing a New Song: African Influences on America's Religious Landscape. Rowman and Littlefield, 2012.

Cole, George. "Transcultureo cubano": la santería, el negrismo y la definición de la identidad cultural cubana a comienzos del siglo XX”. Dissidences, Hispanic Journal of Theory and Criticism, vol. 3, issue 5, November 2012, pp.1-27. 
Cole, Catherine M. Ghana's Concert Party Theatre. Indiana UP, 2001.

Coleman, James S, and Carl Rosberg G, editors. Political Parties and National Integration in Tropical Africa. U California P, 1970.

Collins, John. "The Early History of West African Highlife Music.” Popular Music, vol. 8, no. 3, African Music, (Oct., 1989), pp. 221-30.

Connor, Ryan. "Regimes of Waste: Aesthetics, Politics, and Waste from Kofi Awoonor and Ayi Kwei Armah to Chimamanda Adichie and Zeze Gamboa." Research in African Literatures, vol. 44, no. 4, 2013, pp. 51-68.

Cossío Esturo, Adolfina. Rhythmic Effects in Nicolas Guillen's Poetry. Dirección de Información Científica y Técnica, Universidad de Oriente, 1979.

Coulthard, G.R. Race and Colour in Caribbean Literature. Oxford UP, 1962.

Crayton, Lisa A and Laura La Bella. Globalization: What It Is and How It Works. Enslow Publishing, 2016.

Cunard, Nancy. Essays on Race and Empire. Edited by Maureen Moynagh, Broadview Press 2002.

Dahl, Anthony G. "Resolving the Question of Identity: Nicolás Guillén's 'La balada de los dos abuelos." Afro-Hispanic Review, vol. 14, no. 1, (Spring 1995), pp. 10-17.

Damrosch, David. "Comparative Literature?" Publications of the Modern Language Association (PMLA), vol. 118, no. 2, 2003, pp. 326-30.

Daniel, Yvonne Payne. "Race, Gender, and Class Embodied in Cuban Dance," Contributions in Black Studies: Ethnicity, Gender, Culture, \& Cuba. A Journal of 
African and Afro-American Studies, (Special Section), vol. 12, article 8, 1994, pp. 7087.

Davidson, Basil. Black Star: A View of the Life and Times of Kwame Nkrumah. Allen Lane, 1973.

Davies, Catherine. A Place in the Sun? Women Writers in Twentieth-Century Cuba. Zed Books, 1997.

De la Fuente, Alejandro. "Two Dangers, One Solution: Immigration, Race, and Labor in Cuba, 1900-1930.” International Labor and Working-Class History, no. 51, Workers in Racially Stratified Societies, Spring 1997, pp. 30-49.

---. "Race, National Discourse, and Politics in Cuba: An Overview." Race and National Identity in the Americas, Latin American Perspectives, vol. 25, no. 3, 1998, pp. 43-69.

---. “Myths of Racial Democracy: Cuba, 1900-1912." Latin American Research Review, vol. 34, no. 3, 1999, pp. 39-73.

---. A Nation for All: Race, Inequality and Politics in Twentieth Century Cuba. The U of North Carolina P, 2001.

De la Torre, A., Miguel. La lucha for Cuba: Religion and Politics on the Streets of Miami. U of California P, 2003.

De Lauretis, Teresa. "Eccentric Subjects: Feminist Theory and Historical Consciousness" Feminist Studies, vol. 16, 1990, pp. 115-51.

Díaz-Briquets, Sergio, and Jorge Pérez-López. Corruption in Cuba: Castro and Beyond. U of Texas P, 2006. 
Domínguez, Jorge I. Foreword. Castro, the Blacks, and Africa by Carlos Moore, Centre for Afro-American Studies, U of California, 1988, pp. ix-xvi.

Duke, Dawn. Literary Passion, Ideological Commitment: Toward a Legacy of Afro-Cuban and Afro-Brazilian Women Writers. Bucknell UP, 2008.

Duno Gottberg, Luis. Solventando las diferencias: La ideología del mestizaje en Cuba. Iberoamericana, 2003.

Dye, Alan. Cuban Sugar in the Age of Mass Production: Technology and the Economics of the Sugar Central, 1899-1929. Stanford UP, 1998.

Dzahini-Obiatey, Henry K, et al. "Over Seventy years of a Viral Disease of Cocoa in Ghana: From Researchers' Perspective." African Journal of Agricultural Research, vol. 5, no. 7, 4 Apr. 2010, pp. 476-85.

Earle, Jonathan Halperin. "The Trans-Atlantic Slave Trade, 1500-1800.” The Routledge Atlas of African American History. Edited by Mark C. Carnes, Routledge, 2000, pp. 20-25.

Elias, Maritza. "Dialogue with Maritza Elias on the Massacre of 1912 in La Maya, Cuba.” Entrevista realizada en La Maya, Cuba: 5-de Mayo del año 2001 por Eugène Edward Godfried y Presilia, 2001.

Ellis, Keith. "Caribbean Identity and Integration in the Work of Nicolas Guillén." Caribbean Quarterly, vol. 51, no. 1, 2005, pp. 1-14.

---. “Nicolás Guillén at Seventy,” Caribbean Quarterly, vol. 19, no. 1, Mar. 1973, pp. 87-94.

---. Cuba's Nicolás Guillén: Poetry and Ideology. U of Toronto P, 1983.

Falola, Toyin and Christian Jennings. Sources and Methods in African History: Spoken, Written, Unearthed. U of Rochester P, 2003. 
Farber, Samuel. Cuba since the Revolution of 1959: A Critical Assessment. Haymarket Books, 2011.

---. The Origins of the Cuban Revolution Reconsidered. U of North Carolina P, 2006.

Fernández, Nadine T. Race, Romance, and Revolution: The Cultural Politics of Interracial Encounters in Cuba. U of California P, 1996.

---. Revolutionizing Romance: Interracial Couples in Contemporary Cuba. Rutgers UP, 2010.

Finch, Aisha K. Rethinking Slave Rebellion in Cuba: La Escalera and the Insurgencies of 1841-1844. U of North Carolina P, 2015.

Fisher, David James. Romain Rolland and the Politics of Intellectual Engagement. U of California P, 1988.

Fraser, Robert. The Novels of Ayi Kwei Armah. Heinemann, 1980.

Gadzekpo, Audrey. "The Hidden History of Gender in Ghanaian Print Culture." African Gender Studies: A Reader, edited by Oyèrónké Oyěwùmí. Palgrave Macmillan, 2005, pp. 279-96.

Glazer, Howard. "Architecture and Building industry in contemporary Cuba." Cuba, a Different America, edited by Wilber A. Chaffee and Gary Prevost. Rowman and Littlefield, 1989.

Gocking, Roger S. The History of Ghana. Greenwood Press, 2005.

Goldie, Terry. "A Connection of Images: The Structure of Symbols in The Beautyful Ones Are Not Yet Born.” Kunapipi, vol. 1, no. 1, 1979, pp. 94-107.

Goldstein, Erik. Wars and Peace Treaties: 1816 to 1991. Routledge, 1992.

Gómez, Juan Gualberto. “Confraternidad Cubana.” Adelante, vol. 3, no. 27, 1937. 
González Echevarría, Roberto. “Guillén as Baroque: Meaning in Motivos de Son.” Callaloo, no. 31, Nicolás Guillén: A Special Issue, Spring 1987, pp. 302-17.

González-Sobrino, Bianca and Mathew W. Hughey. "Blanqueamiento." Race and Racism in the United States: An Encyclopedia of the American Mosaic, edited by Charles A. Gallagher and Cameron D. Lippard. Greenwood, 2014, pp. 172-73.

Gravete, Andy. Cuba. New Holland Publishers, 2007.

Gray, Jeffrey, et al. American Poets and Poetry: From the Colonial Era to the Present. (Volume 1: A-L) Greenwood, 2015.

Green, Steven and Karen, Richardson. T Dot Griots: An Anthology of Toronto's Black Storytellers. Trafford Publishing, 2004.

Greene, Sandra E. Slave Owners of West Africa: Decision Making in the Age of Abolition. Indiana UP, 2017.

Guerra, Lillian. The Myth of José Martí: Conflicting Nationalisms in Early TwentiethCentury Cuba. The U of North Carolina P, 2005.

Guillén, Nicolás. "Nací en una imprenta." La Gaceta de Cuba, X-1972. Prosa de Prisa, Tomo III. Editorial Arte y Literatura, 2002, pp. 386-87.

---. Obra poética. 1922-1958. Edited by Ángel Augier, Editorial Letras Cubanas, 1980.

---. Prosa de Prisa 1929-1972. Tomo 1. Editorial Letras Cubanas, 1975.

---. Summa Poética. Edición de Luis Iñigo Madrigal. Letras Hispánicas, 2000.

Gyekye, Kwame. An Essay on African Philosophical Thought: The Akan Conceptual Scheme Cambridge UP, 1995. 
---. Tradition and Modernity: Philosophical Reflections on the African Experience. Oxford UP, 1997.

Hadjor, Kofi Buenor. Nkrumah and Ghana: The Dilemma of Post-Colonial Power. Routledge, 1988.

Hafkin, Jone, and Hanson Bay, editors. Women in Africa: Studies is Social and Economic Change. Heinemann, 1976.

Hamilton, Carrie. Sexual Revolutions in Cuba: Passion, Politics, and Memory. U of North Carolina P, Chapel Hill, 2012.

Hargrove, Jarvis L. The Political Economy of the Interior Gold Coast: The Asante and the Era of Legitimate Trading, 1807-1875. Lexington Books, 2015.

Harper, Phillip Brian. Are We Not Men? Masculine Anxiety and the Problem of AfricanAmerican Identity. Oxford UP, 1996.

Harvey, William B. Law and Social Change in Ghana. Princeton UP, 1966.

Helg, Aline. Our Rightful Share. The Afro-Cuban Struggle for Equality, 1886-1912. The U of North Carolina P, 1995.

Helmick, Gregory. Archival Dissonance in the U.S. Cuban Post-Exile Novel. Cambridge Scholars Publishing, 2016.

Helppie, Chuck. Kennedy Must be Killed. iUniverse Inc. 2009.

Henken, Ted A, et al., editors. Cuba (Nations in Focus). ABC-CLIO, 2013.

Hoetink, Harry. The Two Variants in Caribbean Race Relations: A Contribution to the Sociology of Segmented Societies. Translated by Eva M. Hooykaas. Oxford UP, 1967. 
Hoffman, Barbara G. Griots at War: Conflict, Conciliation, and Caste in Mande. Indiana UP, 2000.

Hord, Fred L and Jonathan Scott-Lee, editors. Am Because We Are: Readings in Black Philosophy. U of Massachusetts P, Amherst, 1995.

Howard, David. Coloring the Nation: Race and Ethnicity in the Dominican Republic. Signal Books, 2001.

Hubel, Teresa, and Neil Brooks, editors. Literature and Racial Ambiguity. Rodopi, 2002.

Hughes, Langston, and Ben Frederic Carruthers, translators. Cuba Libre: Poems by Nicolás Guillén. Anderson and Ritchie, 1948.

Hunter, Emma. Political Thought and the Public Sphere in Tanzania: Freedom, Democracy and Citizenship in the Era of Decolonization. Cambridge UP, 2015.

Ibarra, Jorge. Prologue to Revolution: Cuba, 1898-1958. Lynne Rienner Publishers, 1998.

Iglesias Utset, Marial. Latin America in Translation: A cultural History of Cuba during the US occupation, 1898-1902. The U of North Carolina P, 2011.

Jackson, Richard L. The Black Image in Latin American Literature. U of New Mexico P, 1976.

James, Conrad. "Nicolás Guillén's Women (And Men): Another Look at Some Early Poems." Writing the Afro-Hispanic: Essays on Africa and Africans in theSpanish Carribbean edited by James Conrad. Adonis and Abbey Publishers, 2012, pp. 61-76.

Jedwab, Remi, and Robert, Darko Osei. "Structural Change in Ghana 1960-2010." IIEP Working Paper. Institute for International Economic Policy, George Washington University, 2012, pp. 1-45. 
Johnston, Harry H. A History of the Colonization of Africa by Alien Races. Cambridge UP, 1913.

July, Robert. An African Voice: The Role of the Humanities in African Independence. Duke UP, 1987

Karenga, Maulana. The African American Holiday of Kwanzaa. U of Sankore P, 1989.

Kasfir, Nelson. The Shrinking Political Arena: Participation and Ethnicity in African Politics, with a Case Study of Uganda. U of California P, 1976.

Kaup, Monika. "Our America" That is Not One: Transnational Black Atlantic Disclosures in Nicolás Guillén and Langston Hughes.” Discourse, vol. 22, no. 3, Fall 2000, pp. 87113.

Kibera, Leonard. "Pessimism and the African Novelist: Ayi Kwei Armah's The Beautyful Ones Are Not Yet Born.” Journal of Commonwealth Literature, vol. 14, no. 1, 1979, pp. 64-72.

Kimble, David. A Political History of Ghana. Clarendon Press, 1963.

Kubayanda, Josaphat B. The Poet's Africa: Africaness in the Poetry of Nicolás Guillén and Aimé Césaire. Greenwood Publishing, 1990.

Kutzinski, Vera M. "Sublime Masculinity." Sugar's Secrets: Race and the Erotics of Cuban Nationalism. UP of Virginia, 1993, pp. 163-98.

Lassiter, Sybil M. Multicultural Clients: A Professional Handbook for Health Care Providers and Social Workers. Greenwood Press, 1995. 
Lazarus, Neil. “(Re)turn to the People: Ngũgĩ wa Thiong'o and the Crisis of Postcolonial

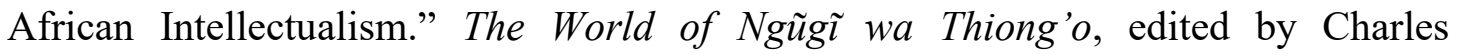
Cantalupo, 1995, pp. 11-26.

---. "Pessimism of the Intellect, Optimism of the Will: A Reading of Ayi Kwei Armah's The Beautyful Ones Are Not Yet Born." Research in African Literatures, Summer, vol. 18, no. 2, 1987, pp. 137-75.

---. Resistance in Postcolonial African Fiction. Yale UP, 1990.

Le Vine, Victor T. Political Corruption: The Ghana Case. Hoover Institution Press, Stanford University, 1975.

Llorens Torres, Luis. Obras completas: poesía. Prólogo por Carmen Marrero, vol. 1, Instituto de Cultura Puertorriqueña, 1967.

Luis, William. "En busca de la cubanidad: el negro en la literatura y la cultura cubana." Heterotropías: narrativas de identidad y alteridad latinoamericana, edited by Carlos A. Jáuregui and Juan Pablo Dabove (Instituto Intemacional de Literatura Iberoamericana Pittsburgh), 2003, pp. 391-415.

Lutz, John. "Pessimism, Autonomy, and Commodity Fetishism in Ayi Kwei Armah's The Beautyful Ones Are Not Yet Born." Research in African Literatures, vol. 34, no. 2, 2003, pp. 94-111.

Lynn-Stoner, Kathryn. From the House to the Streets: The Cuban Woman's Movement for Legal Reform 1898-1902. Duke UP, 1991.

Mañach, Jorge. Historia y estilo. Minerva, 1944.

Martin, Dellita L. "West African and Hispanic Elements in Nicolás Guillén's 'La canción del bongó' South Atlantic Bulletin, vol. 45, no. 1, Jan. 1980, pp. 47-53. 
Martínez-Echazabal, Lourdes. "Mestizaje and the Discourse of National/Cultural Identity in Latin America, 1845- 1959”. Latin American Perspectives, vol. 25, no. 3, 1998, pp. $21-42$.

Mbembe, Achille. On the Postcolony. U of California P, 2001.

Mbiti, John. African Religions and Philosophy. Heinemann, 1989.

McAuley, Christopher. "Race and the Progress of the American Revolutions." Theorizing Revolutions, edited by John Foran, Routledge, 1997, pp. 168-202.

McGoldrick, Monica Joe Giordano and Nydia Garcia-Preto, editors. Ethnicity and Family Therapy. $3^{\text {rd }}$ ed., The Guilford Press, 2005.

McLeod, Marc C. “Sin dejar de ser Cubanos': Cuban Blacks and the Challenges of Garveyism in Cuba.” Caribbean Studies, vol. 31, no. 1, Jan.-Jun. 2003, pp. 75-105.

Miecher, Stephan F. Making Men in Ghana. Indiana U P, 2005.

Mintah, Philomina O. “Images of Women in Armah's Two Thousand Seasons: A Thematic Study." Central University, n.d, pp.1-10. rile-niv.org/numero11/06\%20Philomina.pdf

Montejo Arrechea, Carmen. "Minerva. A Magazine for Women of Colour." Between Race and Empire: African-Americans and Cubans before the Cuban Revolution, edited by Brock and Castañeda Fuertes, Temple UP, 1998,pp. 33-48.

Moore, Carlos. Castro, the Blacks, and Africa. Centre for Afro-American Studies, U of California P, 1988.

Moore, Robin Dale. Nationalising Blackness: Afrocubanismo and Artistic Revolution in Havana, 1920-1940. U of Pittsburgh P, 1997. 
Morehouse College. "Global Conversations with Dr. Ayi Kwei Armah," March 17, 2016. www.youtube.com/watch?v=RpJD7UxSwPQ Accessed 15 May 2015.

Morales Domínguez, Esteban and Prevost Gary. United States Cuban Relations: A Critical History. Lexington Books, 2008.

Moraña, Mabel and Carlos Jáuregui A. Revisiting the Colonial Question in Latin America. Iberoamericana Editorial Verveurt, 2008.

Moraña, Mabel. "The Baroque and Transculturation." Literary Cultures of Latin America: A Comparative History, edited by Mario J. Valdés and Djelal Kadir, Oxford UP, 2004.

Morejón, Nancy, editor. Recopilación de textos sobre Nicolás Guillén. Casa de las Americas, 1974.

---. “Conversación con Nicolás Guillén.” Recopilación de textos sobre Nicolás Guillén, Casa de las Americas, 1974, pp. 31-61.

Mullen, Edward J. "Some Early Readings of Motivos de son.” Romance Quarterly, vol., 39, no. 2, 1992, pp. 221-30.

Muller, Dalia Antonia. Cuban Émigrés and Independence in the Nineteenth-Century Gulf World. U of North Carolina P, 2017.

Murray, David. "British Abolitionists in Cuba, 1833-1845." Historical Papers. The Canadian Historical Association /La Société historique du Canada, Québec, vol. 11, no. 1, 1976, pp. 105-21.

Mwakikagile, Godfred. Western Involvement in Nkrumah's Downfall. New Africa Press, 2015.

Nebo, Chijioke. Treasures in the Nest. Matador, 2009. 
Niemi, Minna. "Challenging moral corruption in the postcolony: Ayi Kwei Armah's The Beautyful Ones Are Not Yet Born and Hannah Arendt's notion of individual responsibility.” Postcolonial Studies, vol. 20, no. 2, 2017, pp. 217-36.

Nnolim, Charles E. "Dialectic as Form: Pejorism in the Novels of Armah." African Literature Today, edited by Eldred Jones, Heinemann, 1979, pp. 207-23.

Nti, Kwaku. "Action and Reaction: An Overview of the Ding Dong Relationship between the Colonial Government and the People of Cape Coast." Nordic Journal of African Studies, vol. 11, no.1, 2002, pp. 1-37.

Ojong Ayuk G. "The Lust for Material Well-Being in The Beautyful Ones Are Not Yet Born and Fragments by Ayi Kwei Armah.” Présence Africaine, Nouvelle série 132, 1984, pp. 33-43.

Okyere, Victor N. Ghana: A Historical Survey. Vinojab Publications, 2010.

Onwueme, Tess, Akaeke. 'Speaking Without Tongue: Silence and Self-Search in Armah's The Beautiful Ones." Ufahamu: A Journal of African Studies, vol. 18, no. 1, 1990, pp. $71-81$

Ortiz, Fernando, and Césare Lombroso. Hampa afrocubana: los negros brujos (apuntes para un estudio de etnología criminal). Librería de F. Fé, 1906.

Ortiz, Fernando. Los cabildos y la fiesta afrocubanos del Día de Reyes. Editorial de Ciencias Sociales, 1992.

---. Los negros brujos. 1906. Ediciones Universal, 1973.

Osborne, Myles, and Kent Kinsley S. Africans and Britons in the Age of the Empires, 1660-1980. Routledge, Taylor and Francis, 2015. 
Ousmane, Sembene. God's Bits of Wood. 1960. Translated by Francis Price, Heinemann, 1962.

Owusu-Ansah, David. "The Society and Its Environment." Ghana, A Country Study, edited by Berry LaVerle, Federal Research Division, Library of Congress, 1995.

Packman, Eric S. Africa in War and Peace. Nova Science Publishers, 2004.

Pappademos, Melina. Black Political Activism and the Cuban Republic. The U of North Carolina P, 2011.

Parekh, Pushpa Naidu and Siga Fatima, Jagne, editors. Postcolonial African Writers: A Bio-bibliographical Critical Sourcebook. Routledge, Taylor and Francis, 1998.

Peñales Moral, Reynold. Afro-Cuban Voices: On Race and Identity in Contemporary Cuba. Edited by Pedro Pérez Sarduy and Jean Stubbs. UP of Florida, 2000.

Pérez-Firmat, Gustavo. The Cuban Condition: Translation and Identity in Modern Cuban Literature. Cambridge UP, 1989.

---. "Mulatto Madrigals." My Own Private Cuba: Essays on Cuban Literature and Culture. Society of Spanish and SpanishAmerican Studies, 1999, pp. 87-107.

Pérez, Louis A. Jr. Army Politics in Cuba, 1898-1958. U of Pittsburgh P, 1976.

---. Cuba under the Platt Amendment, 1902-1934. U of Pittsburgh P, 1986.

---. Cuba: Between Reform and Revolution. Oxford UP, 1988.

---. Lords of the Mountain: Social Banditry and Peasant Protest in Cuba, 1878-1918. U of Pittsburgh P, 1989.

---. The War of 1898: The United States and Cuba in History and Historiography. U of North Carolina P, 1998. 
---. On Becoming Cuban: Identity, Nationality and Culture. U of North Carolina P, 1999.

--. The Structure of Cuban History: Meanings and Purpose of the Past. U of North Carolina P, 2013.

Peters, Christabelle. Cuban Identity and the Angolan Experience. Palgrave Macmillan, 2012.

Philip, Foner S. Antonio Maceo: The "Bronze Titan” of Cuba's Struggle for Independence. Monthly Review Press, 1977.

Ratner, Carl. Cooperation, Community, and Co-Ops in a Global Era. Springer, 2013.

Robaina, Tomás Fernández. "La prosa de Guillén en defensa del negro cubano”. Lo que teníamos de tener, edited by Jerome Branche. Instituto Intemacional de Literatura Iberoamericana, Universidad de Pittsburgh, 2003, pp.131-32.

Robbins, James. "The Cuban Son as Form, Genre and Symbol." Latin American Music Review, vol. 11. no. 2, 1990, pp. 182-200.

Rodríguez, Clara E. "Challenging Racial Hegemony: Puerto Ricans in the United States." Race, edited by Steven Gregory and Roger Sanjek, Rutgers UP, 1994, pp. 131-45.

RoseGreen-Williams, Claudette. "The Myth of Female Sexuality in Spanish Caribbean Poetry: A Deconstructive Critical View.” Afro-Hispanic Review, vol. 12, no. 1, 1993, pp. 16-23.

Saco, José Antonio. "Carta de un cubano a un amigo suyo." Colección de papeles científicos, históricos, politicos, y de otros ramos sobre la isla de Cuba, vol. 3, Editora del Consejo Nacional de Cultura, 1963, pp. 40-1. 
---. "Memoria sobre la vagancia en la isla de Cuba." 1834. Vol. 1, Obras : Ensayo introductorio, compilación y notas de Eduardo Torres Cuevas. Imagen Contemporánea, 2001, pp. 264-341.

Samovar, Larry A, et al. Communication between Cultures. Wadsworth Cengage Learning, 2012.

Sanders, James. "The Expansion of the Fante and the Emergence of Asante in the Eighteenth Century." The Journal of African History, vol. 20, no. 3, 1979, pp. 349-64.

Sardinha, Carl Dennis. The Poetry of Nicolás Guillén: An Introduction. New Beacon Books, 1976.

Schneider, David Murray and Kathleen Gough. Matrilineal Kinship. U of California P, 1961.

Scott, Rebecca J. Slave Emancipation in Cuba: The Transition to Free Labour, 1860-1899. Princeton UP, 1985.

Sierra, María. Enemies Within: Cultural Hierarchies and Liberal Political Models in the Hispanic World. Cambridge Scholars Publishing, 2015.

Skidmore, Thomas. Black into White: Race and Nationality in Brazilian Thought. Brazilian edition: Preto no branco. Raça e nacionalidade no pensamento brasileiro [1974]. Translated by Raul de Sá Barbosa. Paz e Terra, 1989.

Smart, Ian Isidore. Nicolás Guillén. Popular Poet of the Caribbean. U of Missouri P, 1990.

Soyinka, Wole. A Dance of the Forests. Oxford UP, 1963.

Suchlicki, Jaime. Cuba: From Columbus to Coast and Beyond. Potomac Books Inc., 2002.

Swanger, Joanna. Rebel Lands of Cuba: The Campesino Struggles of Oriente and Escambray, 1934-1974. Lexington Books, 2015. 
Szwed, John. Crossovers: Essays on Race, Music, and American Culture. U of Pennsylvania P, 2005.

The New York Times. "The Killing of Banderas.” August 24, 1906.

Thresh, Mike J, et al. "Ghanaian Cocoa Varieties and Swollen Shoot Viruses." Crop Protection, Science Direct, vol. 7, no. 4, August 1988, pp. 219-31.

Toscano, Julian Blain. "Miremos Hacia el Porvenir.” The Negro World, April 12, 1930, p. 7.

Toyin Falola and Matt, Childs D, editors. The Yoruba Diaspora in the Atlantic World. Indiana UP, 2004.

Valdés, Mario J and Djelal Kadir. Literary Cultures of Latin America: A Comparative History: Institutional modes and cultural modalities. Oxford UP, 2004.

Veltmeyer, Henry and Mark Rushton. The Cuban Revolution as Socialist Human Development. Koninklijke Brill NV, 2012.

Vilaboy, Sergio Guerra and Oscar Loyola Vega. Cuba: A History. Ocean Press, 2010.

Wade, Peter. "Images of Latin American Mestizaje and the Politics of Comparison." Bulletin of Latin American Research, vol. 23, no. 3, 2004, pp. 355-66.

White, Clement A. Decoding the Word: Nicolás Guillén as Maker and Debunker of Myth. Ediciones Universal, 1993.

Whiting, Charles G. “The Case for 'Engaged' Literature." Yale French Studies, no.1, Existentialism, Yale UP, 1948, pp. 84-9.

Williams, Claudette. Charcoal and Cinnamon: The Politics of Color in Spanish Caribbean Literature. UP of Florida, 2000. 
Williams, Dorothy. "Black Print in Canada." Multiple Lenses: Voices from the Diaspora Located in Canada, edited by David Divine, Cambridge Scholars Publishing, 2003.

Williams, Lorna V. Self and Society in the Poetry of Nicolás Guillén. Johns Hopkins UP, 1982.

Wright, Derek. “Armah's Ghana Revisited: History and Fiction.” International Fiction Review, vol. 12, no. 1, Winter 1985, pp. 23-27.

Wright, Derek. "Motivation and Motif: The Carrier Rite in Ayi Kwei Armah's The Beautyful Ones Are Not Yet Born." English Studies in Africa, vol. 28, no. 2, 1985, pp. 119-33.

Yankah, Kwesi. "Proverbs: The Aesthetics of Traditional Communication." Research in African Literatures, vol. 20, no. 3, Autumn 1989, pp. 325-46.

Yovanovich, Gordana. "Play as a Mode of Empowerment for Women and as a Model for Poetics in the Early Poetry of Nicolás Guillén." Hispanic Review, vol. 69, no. 1, Winter 2001, 2001, pp. 15-31.

Zackodnik, Teresa C. The Mulatta and the Politics of Race. UP of Mississippi, 2004.

Zeilig, Leo. Class Struggle and Resistance in Africa. Haymarket Books, 2009.

Zuberi, Tukufu. African Independence: How Africa Shapes the World. Rowman \& Littlefield Publishers, 2015.

\section{Secondary Sources}

Achebe, Chinua. No Longer At Ease. Heinemann, 1960.

---. A Man of the People. Heinemann, 1966.

Armah, Ayi Kwei. "Fanon: The Awakener." The Negro Digest, vol. 18, no. 12, Oct. 1969, pp. 4-43. 
---. Why Are We So Blest? Doubleday Press/Anchor Books, 1972.

---. The Healers. East African Publishing House, 1978.

---. “A Mystification: African Independence Revalued.” Pan-African Journal, vol. 2, no. 2, 1984, pp. 141-51.

---. “The Lazy School of Criticism.” West Africa, 25 February 1985, pp. 355-56.

---. “One Writer's Education.” West Africa, 26 Aug. 1986, pp. 1752-53. 